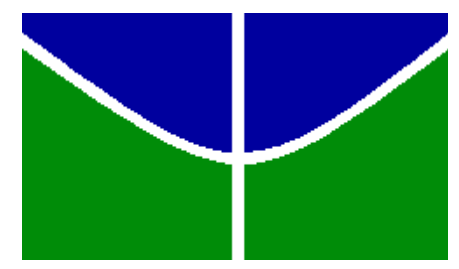

Universidade de Brasília

Faculdade de Educação

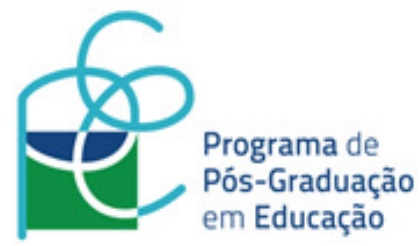

Dinorá de Castro Gomes

Educação Ambiental na Alfabetização de Trabalhadores de Cooperativas de Resíduos Sólidos: por um resgate de elos submersos 
Tese apresentada ao Programa de PósGraduação em Educação da Faculdade de Educação da Universidade de Brasília/UnB, como requisito parcial para a obtenção do título de Doutor em Educação. Área de concentração: Educação Ambiental e Educação do Campo - EAEC.

Orientadora: Professora Doutora Vera Margarida Lessa Catalão 
Autorizo a reprodução e divulgação total ou parcial deste trabalho, por qualquer meio convencional ou eletrônico, para fins de estudo e pesquisa, desde que citada a fonte.

Ficha catalográfica elaborada automaticamente. com os dados fornecidos pelo(a) autor(a)

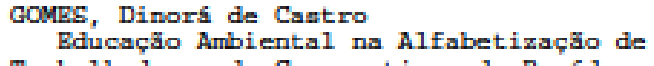
Trabalhadores de Cooperativas de Residuos S6lidoa: por um resgate de elou mubereros / Dinors de Cantro GOMBS; orientador Vera Margarida Lema Cataläo. -Braailia, 2016.

$256 \mathrm{p}$.

Tese (Doutorado - Doutorado em Bducaçāo) -Univeraidade de Bramilia, 2016.

1. Bducaç̄̃o Ambiental. 2. Bducaç̄̃o Popular. 3. Alfabetização de Catadorea. 4. Formaçĩo Humana. 5. Suetentabilidade. I. Leana Catalso, Vera Margarida, orient. II. Titulo. 


\section{DINORÁ DE CASTRO GOMES}

Educação Ambiental na alfabetização de trabalhadores de cooperativa de resíduos sólidos: por um resgate de elos submersos

Tese apresentada ao Programa de PósGraduação em Educação da Faculdade de Educação da Universidade de Brasília/UnB, como requisito parcial para a obtenção do título de Doutor em Educação. Área de concentração: Educação Ambiental e Educação do Campo - EAEC.

Tese defendida e aprovada em 05 de maio de 2016

\section{BANCA EXAMINADORA}

Professora Doutora Vera Margarida Lessa Catalão

Universidade de Brasília (Orientadora)

Professora Doutora Maria Emilia de Castro Rodrigues

Universidade Federal de Goiás (Membro efetivo externo)

Professora Doutora Izabel Cristina Bacellar Zanetti

Universidade de Brasília - CDS (Membro efetivo externo)

Professora Doutora Maria do Socorro Rodrigues Ibañez

Universidade de Brasília - Instituto de Biologia (Membro efetivo externo)

Professor Doutor Erlando da Silva Reses

Universidade de Brasília - Faculdade de Educação (Membro efetivo interno)

Professora Doutora Mônica Molina

Universidade de Brasília - Faculdade de Educação (Suplente) 
Dedico este trabalho a todos os catadores, pela relevância de sua contribuição na cadeia de sustentabilidade da vida. Em especial, aos cooperados colaboradores que confiaram em mim participando desta pesquisa. A todos, meu profundo respeito, admiração, carinho, amor e gratidão. 


\begin{abstract}
AMOR E GRATIDÃO
Aos entes celestiais de força e luz, trazidos pelas manifestações da natureza, que me habitam, fortalecem e me conduzem pelos caminhos da vida.

Ao Programa de Pós-graduação em Educação da Universidade de Brasília, que sempre me atraiu, desde criança, quando frequentei a Faculdade de Educação acompanhando minha irmã, Nazaré Pedrosa, onde ela era professora. Fazer o doutorado nessa mesma instituição é resgatar uma história negada a essa irmã, que teve sua carreira acadêmica profundamente prejudicada, por ter que buscar asilo político em outros continentes.

À minha orientadora professora doutora Vera Margarida Lessa Catalão, gota Terra do oceano cósmico, estrela desse mar imenso de infinitas gotas. Com sua teoria poética me fez perceber outras manifestações da água em diferentes dimensões da vida, atravessando o oceano, navegando rios em continente distante, no encontro de nossas águas, nutrindo o sonho de que outra educação é possível.

Às professoras doutoras Maria Emilia de Castro Rodrigues, Izabel Cristina Bacellar Zanetti, Maria do Socorro Rodrigues Ibañez, Mônica Molina e ao professor doutor Erlando da Silva Reses, que muito me honram aceitando o convite para compor a banca examinadora de defesa desta pesquisa, aquilatando a discussão do encontro da Educação Ambiental com a Educação popular. Aludo, também, a professora doutora Cláudia Márcia Lyra Pato que participou da banca de qualificação, trazendo valiosa contribuição.
\end{abstract}

Às queridas professoras Noely e Janieire, que viveram junto comigo a experiência da turma.

Aos educandos colaboradores desta pesquisa, pela confiança e por tudo o que partilhamos. Meu profundo amor e gratidão.

À cooperativa Acop e a todas as cooperativas que com alegria e afeto me receberam.

À incubadora Social da UFG, aos bolsistas e ao Sr. Fernando, por todo o apoio prestado a esta pesquisa.

À equipe da SME de Goiânia, à DEF-AJA e, especialmente, à equipe do Programa AJAExpansão pelo carinho e riqueza de nossos encontros. 
À equipe do Centro Memória Viva de Goiânia, nas pessoas das professoras doutoras Maria Margarida Machado e Maria Emilia de Castro Rodrigues, pelo estímulo à continuidade da minha formação.

Ao Fórum Goiano de EJA, que me fortalece na luta por um mundo mais justo e mais humano.

A todas as minhas amigas, jardim de lindas flores que dão cor, perfume, leveza e sabor à minha vida.

A todas as pessoas que se entrecruzam com a minha vida e com as quais partilho a existência.

A todos da minha graaande família Castro Gomes: ancestrais, contemporâneos e descendentes, por compartilharmos com amor a teia que nos conecta e religa ao nosso pertencimento ao mundo.

Ao Hélverton, meu grande companheiro nesta vida.

Ao meu amor Virgílio, que com sua existência encanta e emociona a minha vida.

A todo amor que me habita ressignificando a minha existência e me fazendo pertencente a este mundo. 
CA TA DOR

Cata cata catador

Cata as sobras pelo chão

Cata os resíduos da vida

Cata a semente do pão

Cata cata catador

Cata o Sol e cata a Lua

Cata o sonho e cata a lida

Cata a sina que é tua

Cata cata catador

Cata a tua beleza

Cata cata a natureza

Cata o mistério da flor

Cata cata catador

Cata o pranto

Cata o (en)canto

Cata a lição do amor

Dinorá de Castro Gomes Outono de 2016 


\section{RESUMO: \\ breve sussurro das águas}

Este trabalho teve como objetivo analisar a contribuição da Educação Ambiental para alfabetização e formação humana junto a uma turma de trabalhadores em uma cooperativa de catadores de resíduos sólidos na cidade de Goiânia. Traz como tema central "Educação Ambiental na Alfabetização de Trabalhadores de Cooperativas de Resíduos Sólidos: por um resgate de elos submersos”. Buscou-se identificar na pesquisa as possíveis interfaces entre a Educação Ambiental e a Educação Popular, tendo como referência a transversalidade, conforme Barbier, e a educação libertadora, proposta por Paulo Freire. As questões de pesquisa buscam investigar a contribuição da Educação Ambiental para uma aprendizagem significativa na alfabetização de adultos trabalhadores de cooperativas de resíduos sólidos e o papel das estratégias ecopedagógicas para a formação humana emancipatória de alfabetizandos trabalhadores de cooperativas de resíduos sólidos. A experiência de alfabetização foi realizada em uma comunidade de catadores que reside no entorno da cooperativa Acop, na periferia da cidade de Goiânia. A observação participante, a roda de conversa e entrevistas semiestruturadas foram os procedimentos utilizados na construção dos dados. Esta pesquisa se insere no âmbito da pesquisa qualitativa com opção pela pesquisaação e pesquisa participante, desenvolvida por meio de estratégias metodológicas diversificadas e oficinas ecopedagógicas que possibilitassem o aprendizado da leitura, da escrita e das operações matemáticas a partir dos saberes trazidos pelos educandos trabalhadores de cooperativas de resíduos sólidos. Como estratégia de formação, utilizamos a sensibilização, a criatividade e a linguagem poética, como formas de abordagem do conhecimento, a fim de resgatar o potencial de aprendizagem desses educandos, a autoestima e a ampliação da percepção de si e do mundo. A pesquisa revelou o distanciamento entre a vida escolar e a vida daquela comunidade. A persistência foi a maneira possível para fazer a aproximação entre o mundo dos catadores e o da escola, despertando-lhes o desejo de aprender a ler e a escrever. A experiência realizada nesta pesquisa, com o grupo dos catadores, criou vínculos e mobilizou o desejo de que a turma não fosse encerrada, o círculo de cultura se apresenta com possibilidade de dar continuidade aos encontros daquele grupo. A experiência vivida trouxe significativos resultados, pois proporcionou transformações a partir da ampliação da percepção de si na interação afetuosa com a água, o ar, as plantas e com os outros seres, na relação com o meio ambiente. Deste modo, ressalta-se a importância da contribuição da EA para a efetivação de uma educação transformadora, fortalecendo os 
princípios da EP. Elos de compromisso para mudanças sociais que alimentem a vida no Planeta Terra.

Palavras-chave: Educação Ambiental. Educação Popular. Alfabetização de Catadores. Formação Humana. Sustentabilidade. 


\section{ABSTRACT: brief whispers of waters}

This study aimed at analyzing the contribution of Environmental Education for human education and literacy among a group of cooperative solid waste collectors in the city of Goiânia. Its central theme is "Environmental Education in Literacy of Cooperative Solid Waste Collectors: towards the rescue of underlying bonds". In this research, we identified the possible interfaces between Environmental Education and Popular Education, having transversality as a reference, according to Barbier, and freedom education, as posited by Paulo Freire. The research questions seek to investigate the contribution of Environmental Education towards a significant learning in adult literacy for cooperative solid waste collectors and the role of ecopedagogic strategies for emancipatory human education for literacy of participanting solid waste cooperative collectors. The experience of literacy was held in a community of collectors living in the surroundings of the ACOP, on the outskirts of Goiânia. Data was collected from procedures such as participant observation, conversation groups, and semi-structured interviews. This is a qualitative action/participating research developed through several methodological strategies and ecopedagogic workshops which enable learning the following skills: reading, writing, and mathematical operations from the knowledge brought by the students working as solid waste collectors. As an educational strategy, awareness, creativity, and poetic language were used as forms of approaching knowledge, in order to rescue the learners' potential, self-esteem and broadening perception of both oneself and the world. The research revealed the gap between the school and community lives. Persistence was the way to shorten distance between the collectors' world and their school, driving their desire to learn, read, and write. The experience in this research study, with the group of collectors, established bonds and made them wish their classes were not over. The culture circle is likely to continue as group meetings. Experience shared has brought significant outcomes since it has provided them with transformation concerning a widened perception of oneself and in the affective interaction with water, the air, the plants and with other creatures, in their relationship with the environment. Thus, we highlight the importance of EA in contributing to building transformational education, strengthening EP's principles. Bonds of commitment towards change feeding life on the Earth.

Key words: Environmental Education. Popular Education. Collectors' literacy. Human Education. Sustainability. 


\section{RESUMEN: \\ breve susurro de las aguas}

Este trabajo tuvo como objetivo analizar la contribución de la Educación Ambiental para la alfabetización y formación humana junto a un grupo de trabajadores en una cooperativa de recogedores de residuos sólidos en la ciudad de Goiânia. Trae como tema central "Educación Ambiental en la Alfabetización de Trabajadores de Cooperativas de Residuos Sólidos: por un rescate de vínculos sumergidos". Se ha buscado identificar en la investigación las posibles interfaces entre la Educación Ambiental y la Educación Popular, teniendo como referencia la transversalidad, conforme Barbier, y la educación libertadora, propuesta por Paulo Freire. Las cuestiones en pauta buscan investigar la contribución de la Educación Ambiental para un aprendizaje significativo en la alfabetización de adultos trabajadores de cooperativas de residuos sólidos y el papel de las estrategias ecopedagógicas para la formación humana emancipadora de estos alfabetizandos. La experiencia de alfabetización fue realizada en una comunidad de recicladores que reside en el entorno de la cooperativa Acop, en la periferia de la ciudad de Goiânia. La observación participante, la rueda de conversación y entrevistas semiestructuradas fueron los procedimientos utilizados en la construcción de los datos. Esta investigación se insiere en el ámbito de la investigación cualitativa con opción por la investigación-acción e investigación participante, desarrollada por medio de estrategias metodológicas diversificadas y oficinas eco pedagógicas que permitieran el aprendizaje de la lectura, de la escrita y de las operaciones matemáticas a partir de los saberes traídos por los educandos trabajadores de cooperativas de residuos sólidos. Como estrategia de formación, utilizamos la sensibilización, la creatividad y el lenguaje poético, como formas de abordaje del conocimiento, a fin de rescatar el potencial de aprendizaje de esos educandos, la autoestima y la ampliación de la percepción de sí y del mundo. La investigación ha revelado el distanciamiento entre la vida escolar y la vida de aquella comunidad. La persistencia fue la manera posible para hacer la aproximación entre el mundo de los recicladores y el de la escuela, despertándoles el deseo de aprender a leer y escribir. La experiencia realizada en esta investigación, con el grupo de recicladores, ha creado vínculos y ha movilizado el deseo de que el grupo no fuera encerrado, el círculo de cultura se presenta con posibilidad de continuar con los encuentros de aquel grupo. La experiencia vivida ha traído significativos resultados, ya que ha proporcionado transformaciones a partir de la ampliación de la percepción de sí en la interacción afectuosa con el agua, el aire, las plantas y con los otros seres, en la relación con el medio ambiente. De 
este modo, se destaca la importancia de la contribución de la EA para la concreción de una educación transformadora. Fortaleciendo los principios de la EP. Vínculos de compromiso para cambios sociales que alimenten la vida en el Planeta Tierra.

Palabras claves: Educación Ambiental. Educación Popular. Alfabetización de Recicladores. Formación Humana. Sostenibilidad. 


\section{LISTA DE IMAGEM}

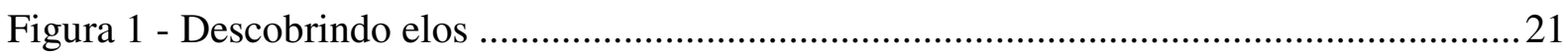

Figura 2 - Minha mãe de leite no canavial da fazenda Roma................................................28

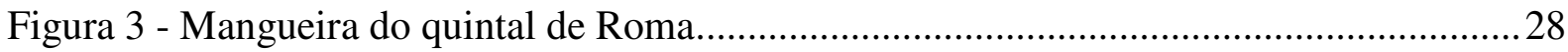

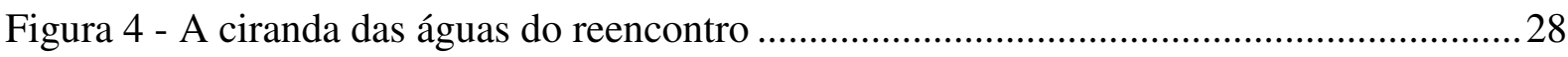

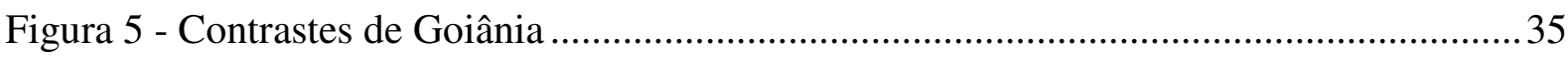

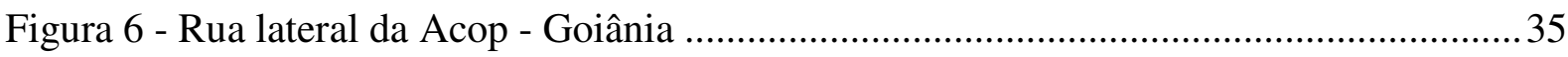

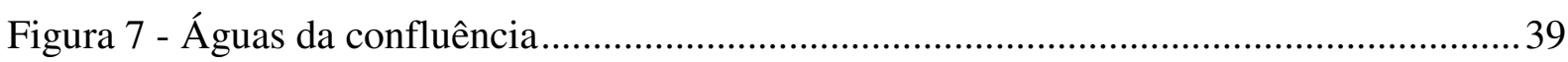

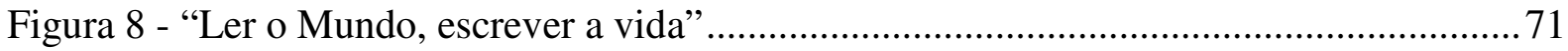

Figura 9 - Equipe do AJA-Expansão e educadoras populares. ...............................................92

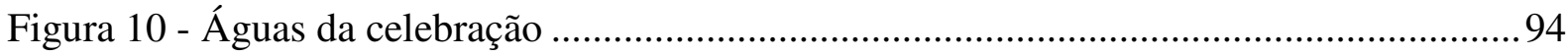

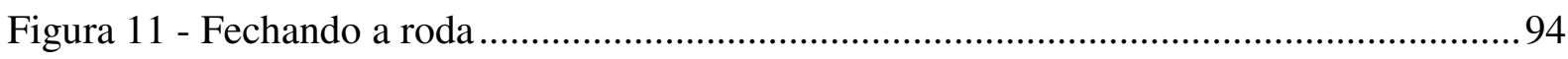

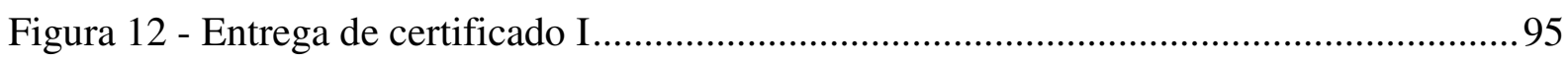

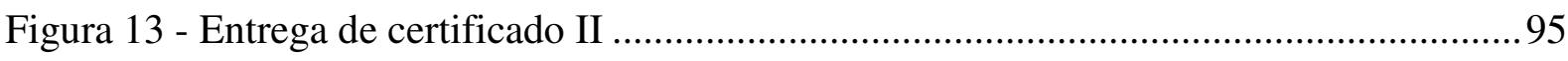

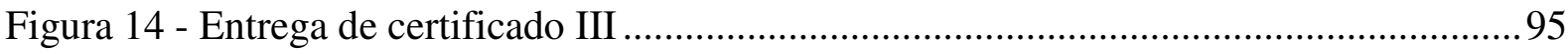

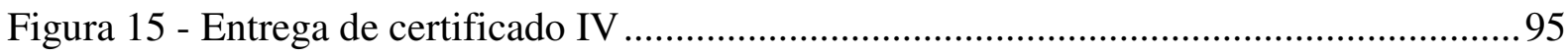

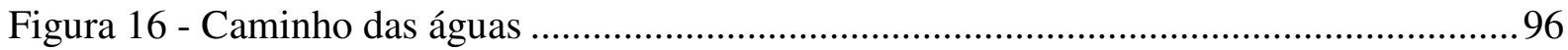

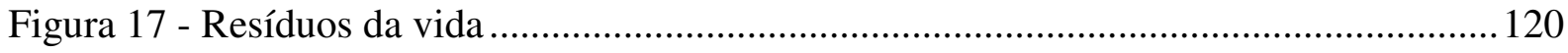

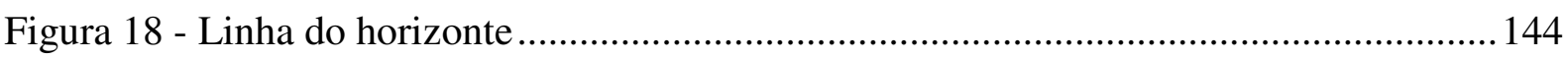

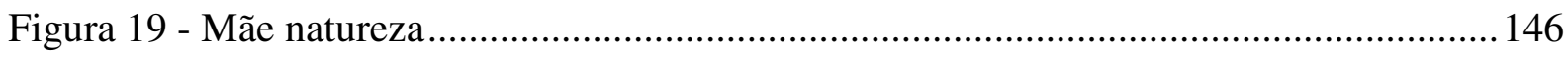

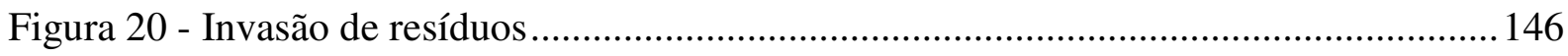

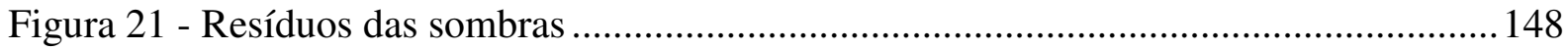

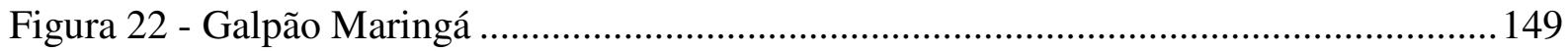

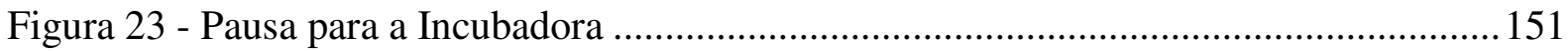

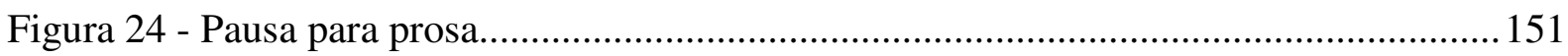

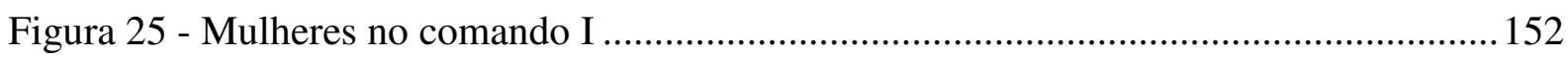

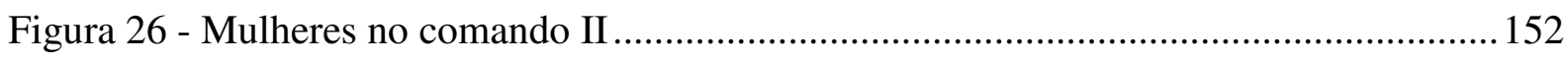

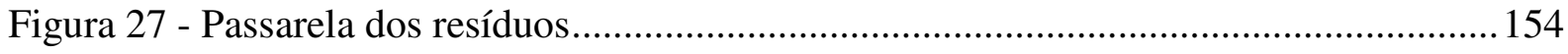

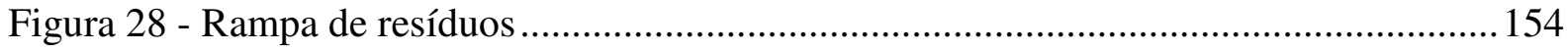

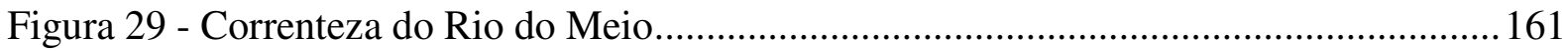

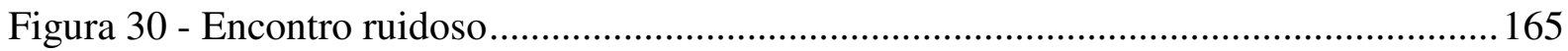

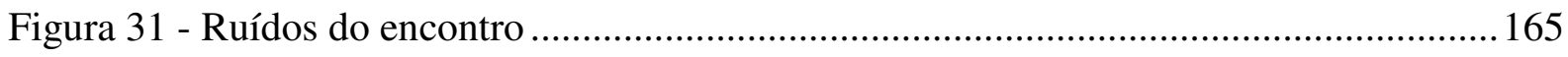

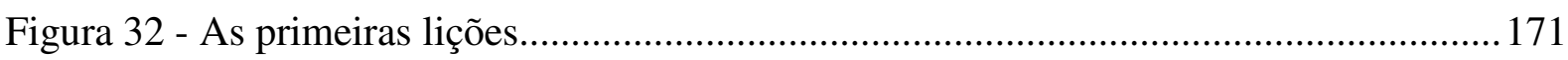


Figura 33 - Roda de delicadezas.

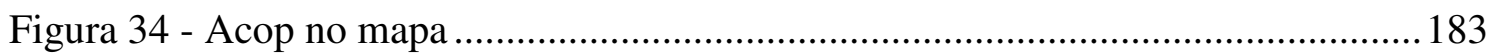

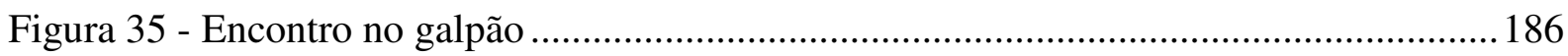

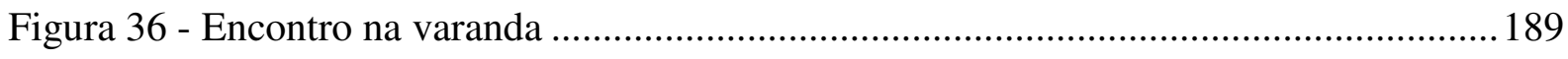

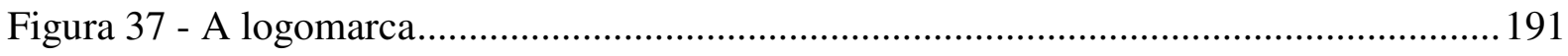

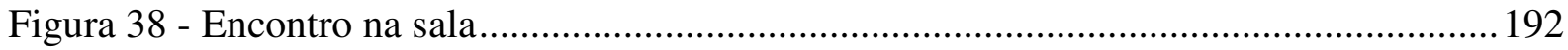

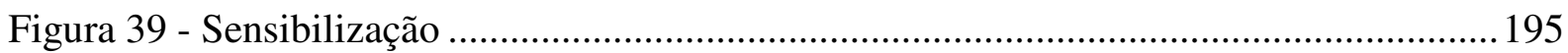

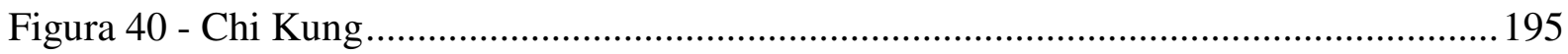

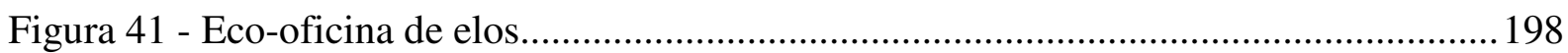

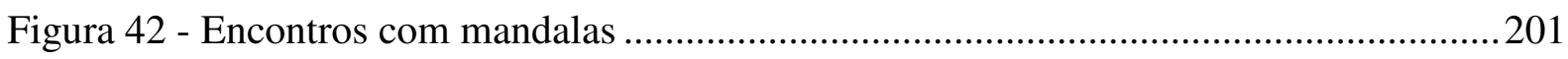

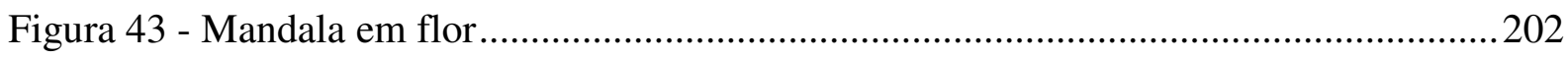

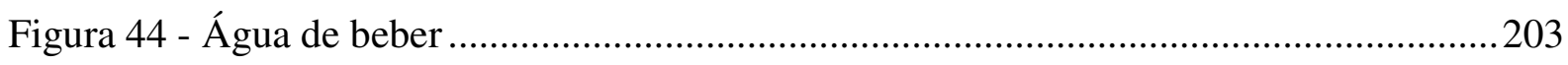

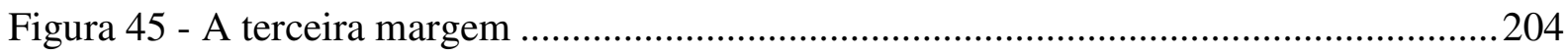

Figura 46 - Memorial do Cerrado com professor Altair Sales .............................................206

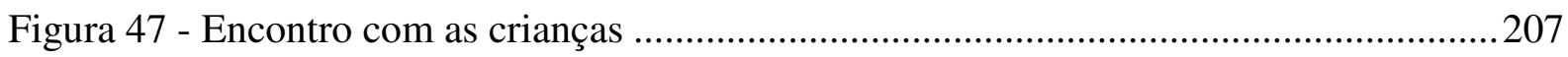

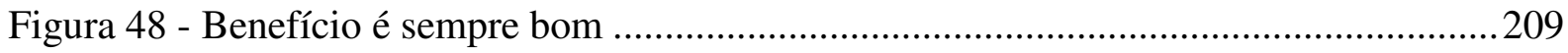

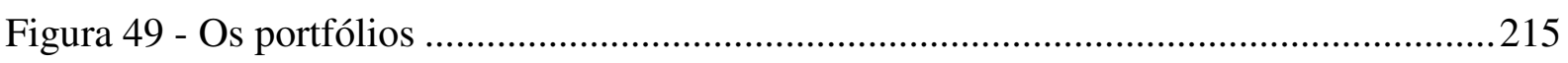

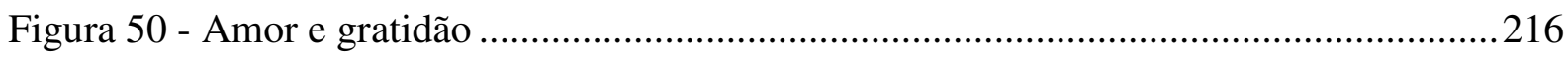

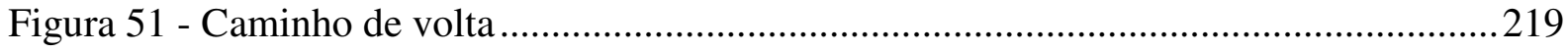

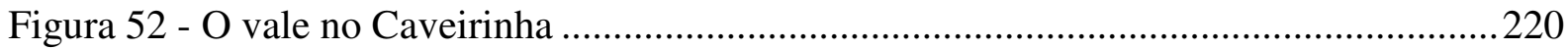




\section{LISTA DE QUADROS}

Quadro 1 - Educação: processo dominante ou transformador ............................................... 70

Quadro 2 - Projeção de intenções do Projeto AJA .................................................................... 81

Quadro 3 - Redução da demanda por alfabetização no município de Goiânia .........................82 


\section{LISTA DE SIGLAS}

Acop

AJA

AMMA

BIRD

CEE

CEFPE

CME

CMV

CNBB

COMURG

Confintea

Coocamare

Cooperfam

Cooprec

CooperMas

Cooper Rama

CD

CEROF

DDT

DEF-AJA

EA

EAEC

EAJA

EJA

EP

FAV

FE

FMI

GEAJA

IBAMA

IBGE

Associação de Catadores de Materiais Recicláveis Ordem e Progresso Alfabetização de Jovens e Adultos

Agência Municipal do Meio Ambiente

Banco Internacional para a Reconstrução e Desenvolvimento

Conselho Estadual de Educação

Centro de Formação dos Profissionais da Educação

Conselho Municipal de Educação

Centro Memória Viva: Documentação e Referência em EJA, Educação Popular e Movimentos Sociais

Confederação Nacional dos Bispos do Brasil

Companhia de Urbanização de Goiânia

Conferência Internacional de Educação de Adultos

Cooperativa dos Catadores de Material Reciclável

Cooperativa de Selecionadores de Materiais Recicláveis Família Feliz

Cooperativa de Reciclagem de Lixo

Cooperativa dos Catadores de Materiais Recicláveis "Meio Ambiente Saudável"

Cooperativa de Material Reciclável Reciclamos e Amamos o Meio

Ambiente

Compact Disc

Centro de Referência Oftalmológica do Hospital das Clínicas da UFG

Dicloro - Difenil - Tricloroetano

Divisão de Educação Fundamental de Adolescentes, Jovens e Adultos Educação Ambiental

Educação Ambiental e Educação do Campo

Educação de Adolescentes, Jovens e Adultos

Educação de Jovens e Adultos

Educação Popular

Faculdade de Artes Visuais

Faculdade de Educação

Fundo Monetário Internacional

Gerência de Educação de Adolescentes, Jovens e Adultos

Instituto Brasileiro do Meio Ambiente

Instituto Brasileiro de Geografia e Estatística 
ITCPS Incubadoras Tecnológicas de Cooperativas Populares

MEB Movimento de Educação de Base

MMA Ministério do Meio Ambiente

MNCR Movimento Nacional dos Catadores de Material Reciclável

Mova Movimento de Alfabetização

MST Movimento dos Sem Terra

OCB Organização das Cooperativas do Brasil

ONU Organização das Nações Unidas

PAC Projetos Alternativos Comunitários

PBA Programa Brasil Alfabetizado

PEV Ponto de Entrega Voluntária

PGCS Programa Goiânia Coleta Seletiva

PIEA Programa Internacional de Educação Ambiental

PME Plano Municipal de Educação

Pnad Pesquisa Nacional por Amostra de Domicílios

PNUMA Programa das Nações Unidas para o Meio Ambiente

PNRS Política Nacional de Resíduos Sólidos

PROEC Pró-Reitoria de Extensão e Cultura

PUC-Goiás Pontifícia Universidade Católica de Goiás

RME Rede Municipal de Educação

SCA Sistema Cooperativista dos Assentados

SEMA Secretaria Especial do Meio Ambiente

SENAES Secretaria Nacional de Economia Solidária

SGPA Sociedade Goiana de Pecuária e Agricultura

SME Secretaria Municipal de Educação de Goiânia

TCC Trabalho de Conclusão de Curso

UFG Universidade Federal de Goiás

UnB Universidade de Brasília

Unesco Organização das Nações Unidas para a Educação, a Ciência e a Cultura

UNICEF Fundo das Nações Unidas para a Infância

ZPA Zona de Proteção Ambiental 


\section{SUMÁRIO}

Educação Ambiental na Alfabetização de Trabalhadores .....................................................22

de Cooperativas de Resíduos Sólidos: por um resgate de elos submersos ..............................22

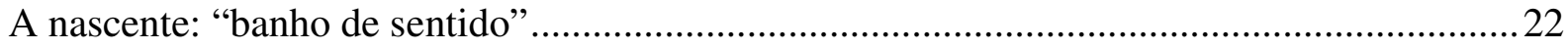

Introdução: lançando-me em águas profundas ....................................................................29

1. Considerações iniciais: águas que fertilizam o campo …................................................... 30

1.1 Goiânia: um contexto em muitas águas ........................................................................ 33

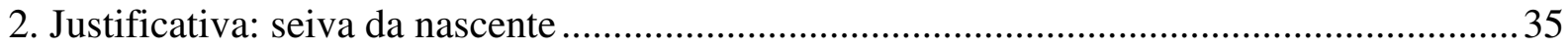

3. Questões que emergem da força das águas ..................................................................... 37

4. Objetivo Geral: ao encontro das águas correntes ................................................................ 37

5. Objetivos específicos: águas em movimentos conexos ......................................................37

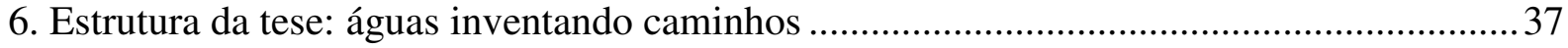

Capítulo 1 - A natureza das águas que conduzem para a confluência da educação ambiental com a educação popular

1.1 Introdução: águas ruidosas da Educação Ambiental e da Educação Popular lançadas em uma experiência de aprendizagem significativa na alfabetização de adultos catadores ........40

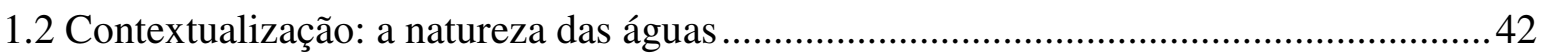

1.3 Educação Popular e Educação Ambiental: confluência das águas ................................54

Capítulo 2 - A alfabetização de adultos nas águas do AJA-Expansão ......................................72

2.1 Introdução: a força do encontro das águas................................................................ 72

2.2 Programa AJA-Expansão: a fonte de suas águas ....................................................... 74

2.3 A parceria entre o curso e o percurso ...................................................................... 85

Capítulo 3 - A metodologia do contorno das águas e a definição do leito ..............................97

3.1 Introdução das águas que formam o leito que se apresenta ......................................... 97

3.2 Águas da metodologia na arte de inventar caminhos.............................................. 102

3.3 Contorno das margens definidas pelo incontível curso das águas ............................... 107

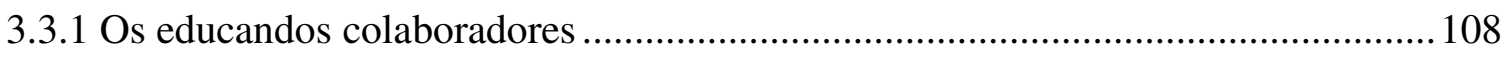

3.3.2 O período de realização da pesquisa ................................................................... 108

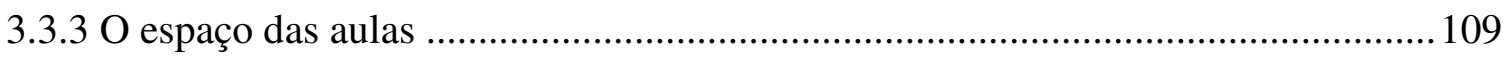

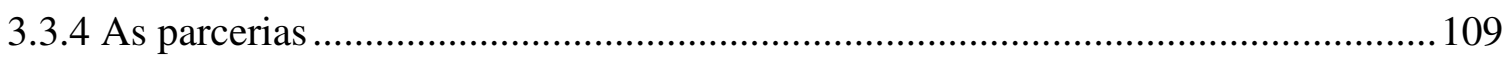

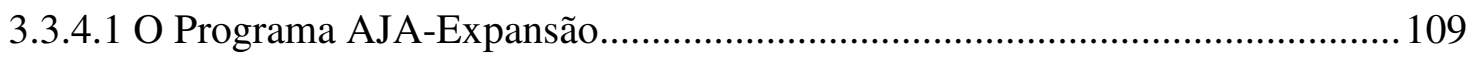

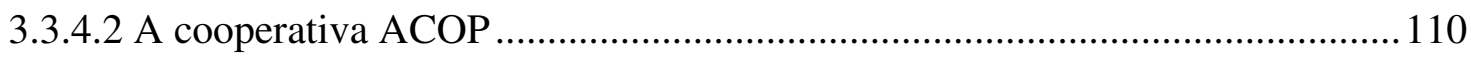

3.3.4.3 A Incubadora Social da Universidade Federal de Goiás ............................... 110

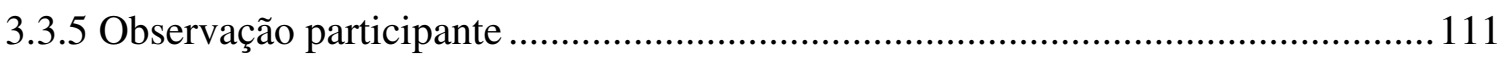

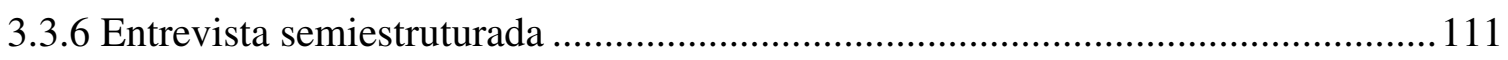




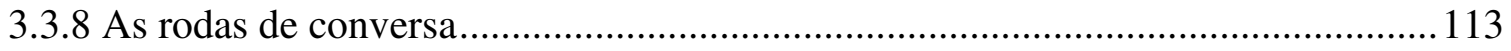

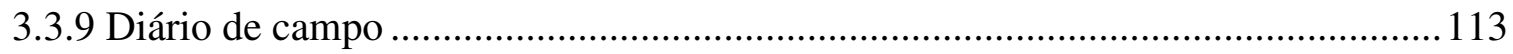

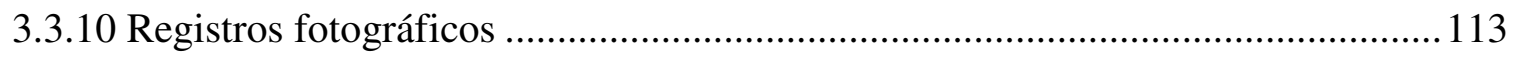

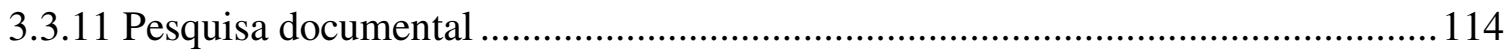

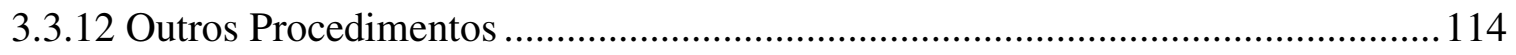

3.3.12.1 Pedido de autorização para realização da pesquisa junto ao AJA-Expansão 114

3.3.12.2 Levantamento da demanda de catadores que não sabiam ler e escrever ........114

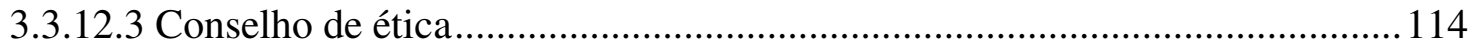

3.3.12.4 Termo de Consentimento Livre e Esclarecido ...............................................115

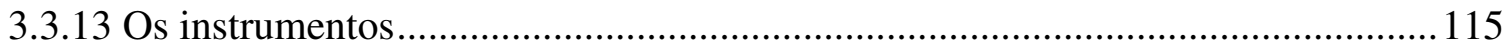

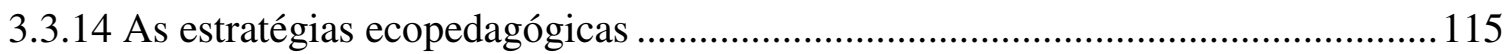

Capítulo 4 - Cooperativas de resíduos SÓLIDOS: movimento das águas no sustento da vida

4.1 Introdução: partilhando as águas da cooperação

4.2 As águas da Educação Ambiental no movimento entre a cooperação, o cooperativismo e

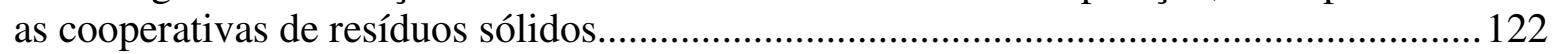

4.3 As cooperativas de resíduos sólidos de Goiânia: um espaço de interlocução no curso das águas entre a Educação Popular e a Educação Ambiental.................................................... 133

Capítulo 5 - Apresentação dos resultados e análise interpretativa dos dados: correnteza das águas

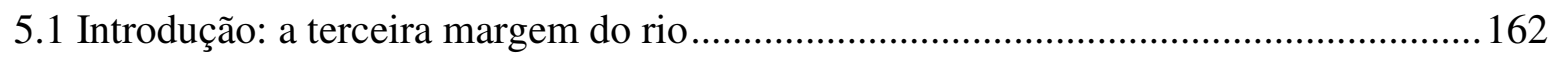

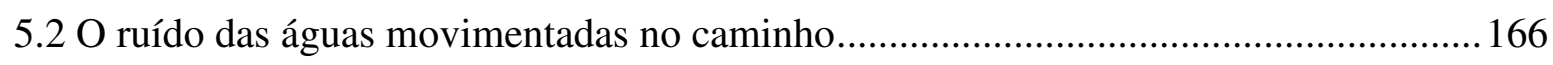

5.3 Águas da experiência vivida lançadas em mandalas se abrindo em flor .......................173

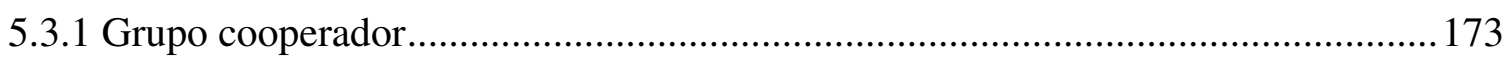

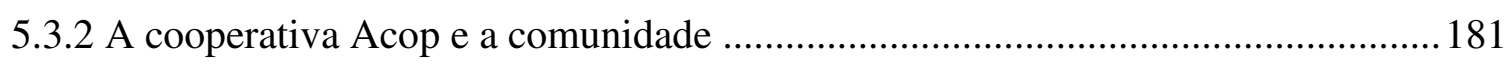

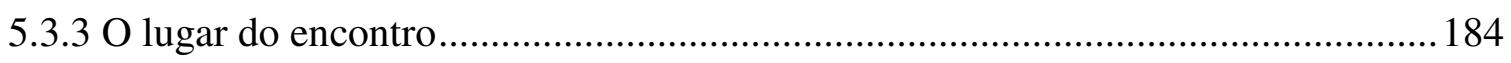

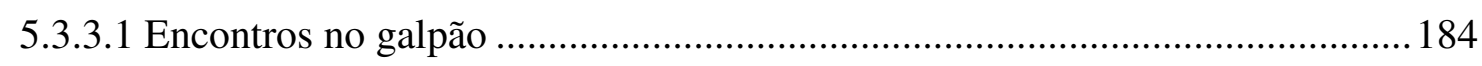

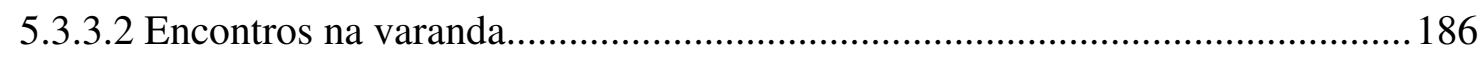

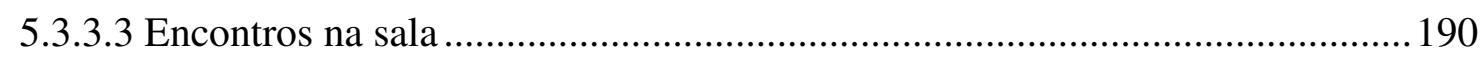

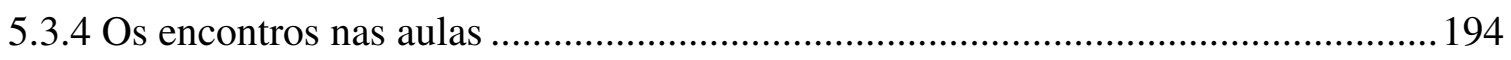

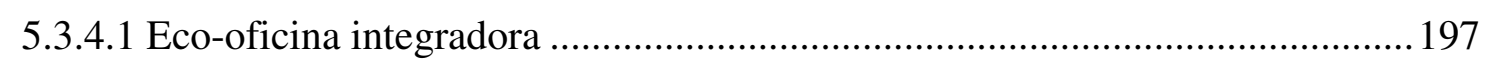

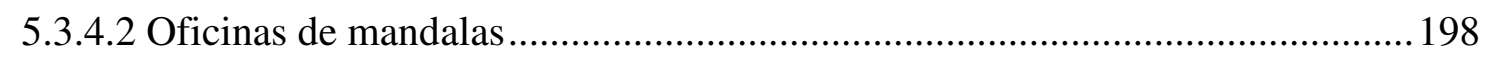

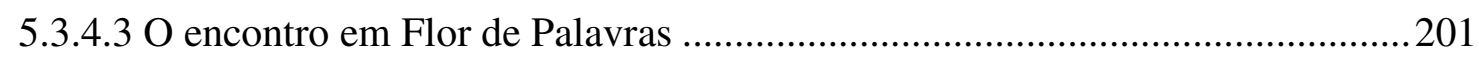

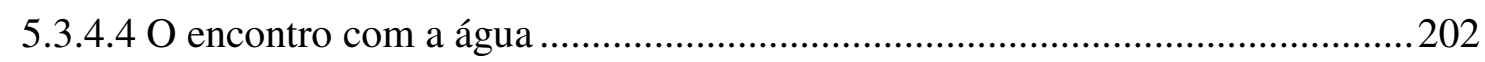

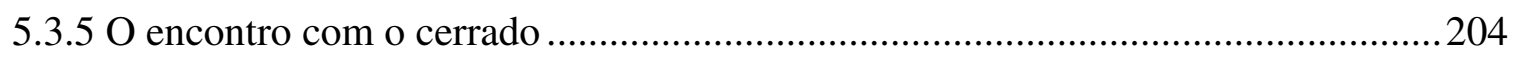


5.3.6 $\mathrm{O}$ encontro com as crianças

5.3.7 Os "benefícios"

5.3.8 Os óculos

5.3.9 A formação

5.3.10 O portfólio

5.3.11 A transdisciplinaridade.

5.4 Ecos dos ruídos das águas correntes 216

CONSIDERAÇÕES: o vale das águas movimentadas no caminho 221

REFERÊNCIAS BIBLIOGRÁFICAS: fontes acopladas 227

APÊNDICE A - Dados pessoais e escolares dos cooperados 234

APÊNDICE B - Roteiro para entrevista com Sr. Fernando 237

APÊNDICE C - Roteiro para entrevista com Naná 239

APÊNDICE D - Roteiro para entrevista com Seu Iramar . 241

APÊNDICE E - Planejamento de aula 243

APÊNDICE F - Roteiro para roda de conversa 244

ANEXO A - Solicitação para realização da pesquisa, junto à SME de Goiânia. 245

ANEXO B - Termo de anuência da SME de Goiânia 247

ANEXO C - Parecer de autorização da DEF-AJA 248

ANEXO D - Termo de consentimento livre e esclarecido educandos 250

ANEXO E - Termo de consentimento livre esclarecido Sr. Fernando 251

ANEXO F - Termo de consentimento livre esclarecido Elizângela.......................................252

ANEXO G - Termo de consentimento livre esclarecido Seu Iramar 253

ANEXO H - Cadastro do educando junto ao programa AJA-Expansão .254

ANEXO I - Cadastro do Educador popular junto ao AJA-Expansão 255 
Educação Ambiental na Alfabetização de Trabalhadores de Cooperativa de Resíduos Sólidos: por um resgate de elos submersos

Figura 1 - Descobrindo elos

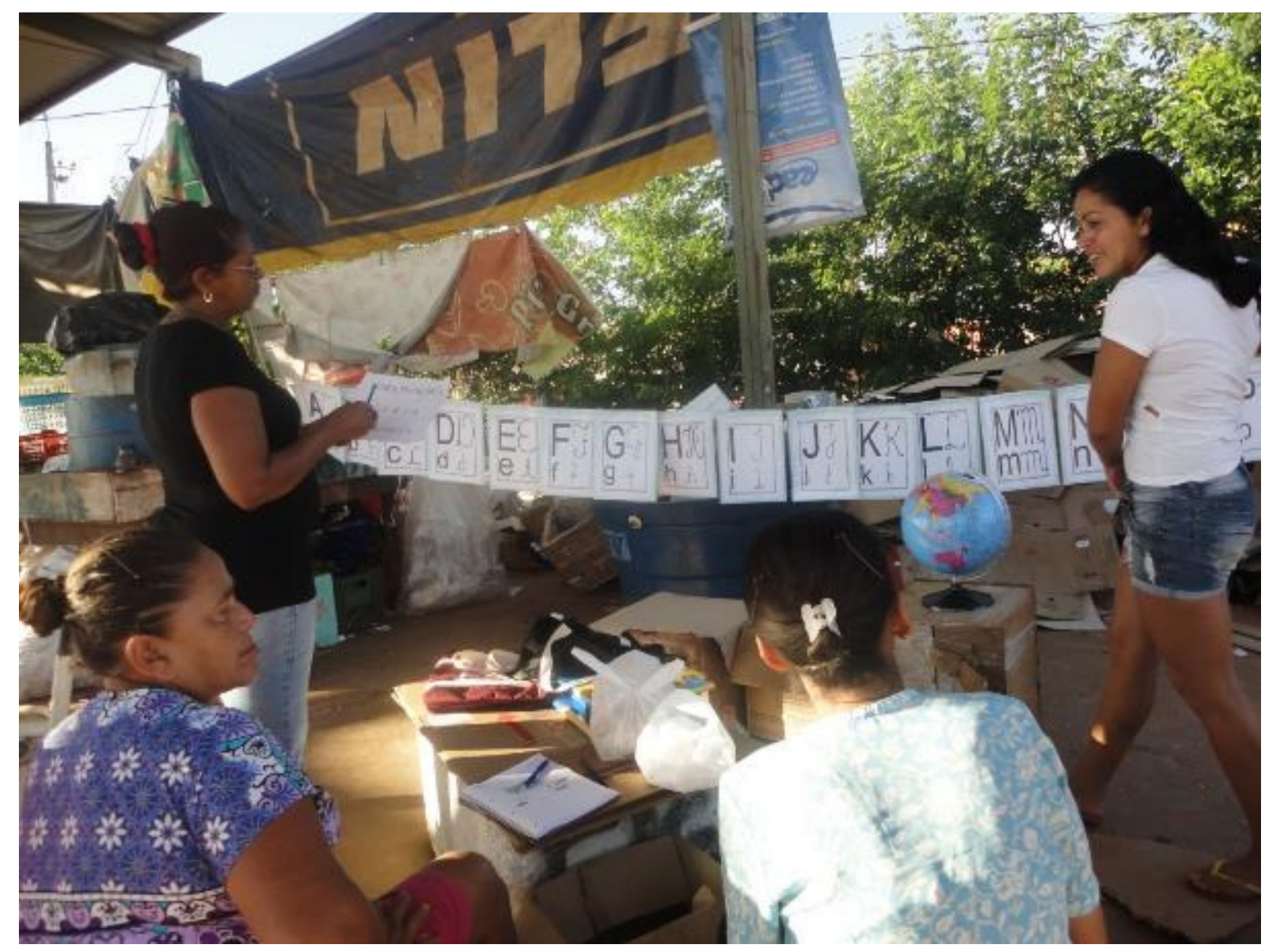

Fonte: Acervo da pesquisa. Sala de aula no galpão da Acop. Maio de 2014. 


\title{
EDUCAÇÃO AMBIENTAL NA ALFABETIZAÇÃO DE TRABALHADORES DE COOPERATIVAS DE RESÍDUOS SÓLIDOS: POR UM RESGATE DE ELOS SUBMERSOS
}

\author{
Visto de longe, o corpo de nosso Planeta \\ está envolto neste elemento fluido, azulado e movente. \\ Visto de perto, toda comunidade de vida se abastece, \\ hidrata-se,orienta-se e se movimenta \\ no sinuoso caminho dos rios ou na vastidão dos oceanos. \\ E, não tão visível, mas extremamente operante, \\ pode-se perceber a intrincada teia de relações \\ ora solidárias, ora conflitantes na disputa de domínios sobre a água. \\ (RIBEIRO, CATALÃO e FONTELES 2014, p.5)
}

\section{A NASCENTE: “BANHO DE SENTIDO”}

A fonte onde brota a água é a mesma onde nasce a vida. A água conduz a vida, a vida do nosso Planeta. Presente em todos os lugares, dentro e fora do coração, ela permeia as relações, contorna as ações, define as decisões e dá cor, sentido e sabor à criação. Assim, submergida nessa revelação, apresento este trabalho envolta no mais profundo entendimento de que a água não é somente uma fórmula científica. Para muito além de uma relação mercadológica e utilitarista, bebo da fonte que compreende a água em sua dimensão cultural, poética e espiritual. Compartilho esse pensamento com Ribeiro, Catalão e Fonteles (2014, p. 5) que explicam:

\begin{abstract}
A água é a molécula mais abundante de nosso corpo, mais abundante do planeta. Sabemos que a água não significa tão somente a equação científica: $\mathrm{H}^{2} \mathrm{O}$, ou seu manejo sustentável como querem os utilitaristas. Água para nós transcende os limites do uso e das necessidades elementares de tudo que vive sobre a Terra, ela é um elemento carregado de simbologias ancestrais e de nossas lembranças originais de termos navegado no líquido amniótico e confortável desde o seio materno. Por isso precisamos tanto de fazer aflorar uma inteligência sensível e criativa para ver e sentir a água, nas suas dimensões simbólicas poética, cultural e espiritual tão comum às tradições primevas de todos os povos da Terra.
\end{abstract}

Permeada por esse entendimento, observo que a água envolve a temática desta pesquisa, "Educação Ambiental na Alfabetização de Trabalhadores de Cooperativas de Resíduos Sólidos: por um resgate de elos submersos”, pois essa temática possui um caráter que situa esses trabalhadores em uma ação de religação entre o homem e a natureza, ao lidarem cotidianamente com a triagem de resíduos sólidos. Dessa maneira, juntamente com o 
rigor acadêmico, requer também, da mesma forma que a água, um tratamento integrado nas dimensões simbólicas poética, cultural e espiritual que submerge a todos.

A abordagem transversal proposta por Barbier, ao que se refere à "existencialidade interna" e que conduz o sujeito ao reconhecimento do pertencimento, resgata em mim este sentimento de pertencimento ao tema desta pesquisa em vários momentos, mas especialmente quando me transporta ao "banho de cuia" do tempo de minha infância, nos cocais maranhenses. Esse banho era tomado num banheiro (lugar exclusivo para banhar) em forma de espiral, feito de pindoba. Rodeado pela floresta, próximo a um poço, a água retirada com um balde era conduzida para o banheiro e colocada em um pote de barro que ficava sobre uma pedra, no núcleo dessa espiral e, sobre outra pedra, nos banhávamos retirando com uma cuia a água fresca do pote. A floresta, a espiral, o banho. Como aquele momento vivido poderia hoje deixar de ser um profundo "banho de sentido"?

Transversalidade como "banho de sentido" no qual o conjunto das sequências existenciais do sujeito se acham postas em ordem e demarcadas numa coerência que o sujeito reconhece como lhe pertencendo. Essa transversalidade implica uma abertura a um máximo de referências que possam vir "jogar" (jouer) e estruturar a vida do sujeito. (BARBIER, 1997, p. 22, grifos do autor.)

A consciência deste "banho de sentido" suscita a relevância de saber que as leituras, as vivências, os diálogos, as trocas, as aprendizagens e os conhecimentos integrados à minha subjetividade, à minha história, às minhas emoções, às águas que permeiam a minha existência, devem e podem conviver juntos em um espaço acadêmico. Esta percepção vem promovendo mudanças significativas em mim, valorizando os meus saberes, mas fazendo emergir novas congruências na medida em que me vejo e tomo a consciência de que o sentido profundo de cada parte vai constituir o sentido do todo, em movimento, mas indissolúvel. Agora, invento novas aproximações na busca de integração entre a compreensão do mundo e minha maneira de nele estar, procurando a relação profunda que existe entre a objetividade do fazer científico e a vida, compreendendo que se é possível estar em plenitude na vida, então é possível estar em plenitude no desempenho do trabalho acadêmico, integrando-o à vida. Esse sentimento profundo de pertencimento ao que me proponho na empreitada desta formação e ao meu processo de conhecimento se fortalece também com Sá (2005), quando diz:

Parece, então que o princípio do pertencimento traz em seu bojo a questão da subjetividade como uma dimensão intrínseca do conhecimento vivo e humano, e que integrá-la é condição de acesso à objetividade, isto é, à 
possibilidade de um conhecimento que se sabe pertencente e se quer compatível com a complexidade do vivido. (p. 253)

A partir desses entendimentos, podemos compreender a relevância da relação da minha história de vida delineando o rumo da minha trajetória intelectual, onde entrelaçadas uma à outra, seguindo o leito da vida, vão juntas me fazendo no percurso. Um percurso cheio de sentidos que demonstram o meu pertencimento ao tema desta pesquisa, expressando uma relação profunda com este trabalho. Tramado na escola pública meu caminho intelectual sempre resistiu refletindo "primeiro, a "leitura" do mundo em que me movia; depois, a leitura da palavra que nem sempre, ao longo de minha escolarização, foi a leitura da "palavramundo". (FREIRE 2009, p.12, grifos do autor)

O mundo onde nasci e vivi até o final da primeira infância, 7 anos de idade, foi marcante e definidor da minha relação com a vida. Esse mundo foi em uma fazenda na região dos cocais, no interior do Maranhão, fronteira com o Pará. Num convívio intenso com a floresta: muito mato, muitos bichos e igarapés. Ali aprendi, tal qual nosso mencionado educador, a ler o mundo ao som dos bandos de periquitos em revoada atacando as goiabeiras e dos macacos nas frondosas mangueiras do quintal. Ao ruído da floresta. Distinguindo o timbre do canto das aves diurnas e das aves noturnas. Observando, da janela, lagartas comendo as folhas da goiabeira que estendia seus galhos até o alcance das minhas mãos e a se transformarem em borboletas no voo liberto de seus casulos. Com o cheiro do gado no curral e o carro de boi rangendo na moagem da cana. Identificando a fruta madura na leitura do toque, do cheiro e das cores. Disputando com os porcos as mangas caídas ao chão. Personificando árvores e levando ferroadas de marimbondo. Contemplando o voo dos pássaros e entregando-me à força do vento forte, no desejo de me fazer voar.

Roma, esse o seu nome, era uma fazenda do ciclo da cana de açúcar. Tinha, portanto, um sítio com uma casa grande assobradada, cuja varanda de tempos em tempos se transformava em sala de alfabetização de adultos por iniciativa do meu pai, a casa de engenho em frente e ao lado uma capela, compondo uma forma triangular. Em torno deste sítio havia, por trás da casa de engenho, o curral e por trás da casa grande e da igreja, a floresta. Em volta desse espaço e pela floresta, os trabalhadores faziam suas casas e ali vivíamos e constituíamos uma comunidade que, conduzida pelos vínculos da sobrevivência, do trabalho e das emoções da vida, muitos outros iam se constituindo nas relações de todo dia. Ali eram cultivadas as crenças, as danças, as cantorias, as comidas. O bumba boi, os tambores, os devotos, o Baile de São Gonçalo, as missas e batizados quando algum padre por ali passava. Doce de espécie, 
café com manuê e com bolo de tapioca, tarira seca com farinha d'água. A vida aprendida e ensinada na troca permanente de saberes e sabores.

Meu pai foi o único filho de sua irmandade que ficou na fazenda, com a missão de acompanhar seus pais, meus avós, frustrando o seu desejo de continuar estudando, como o fizeram seus irmãos. Ali se apaixonou, casou e se dedicou a criar os filhos, botando-os para estudar na capital, realizando neles o seu desejo de estudar. 15 filhos. Em 1967, vendeu a fazenda Roma, escriturou outras partes da terra doando-as a alguns trabalhadores, e em fevereiro do ano seguinte, numa grande peripécia, se mudou para Brasília levando toda a família. Meu pai e minha mãe embarcaram com 10 dos 15 filhos, sendo eu a mais nova. Os primogênitos já haviam partido para outros lugares, abrindo caminhos. A filha mais velha, a segunda da prole, que já morava em Brasília e era professora da Faculdade de Educação da UnB, foi a grande aliada de meus pais, tramando com eles e encorajando-os nessa aventura.

A mudança de nossa família para Brasília foi um impacto na vida de muitas pessoas. Para a família, por ter que se adaptar a um novo modo de viver. Já não plantávamos a mandioca, para a farinha e o bolo. Não pescávamos mais o peixe, para o almoço do dia, nem abatíamos a rês para o banquete das festas. A garapa parou de escorrer na casa de engenho: cessou o melado, acabou o açúcar e a cachaça. Na cidade, o valor de troca era a moeda na mercearia mais próxima e essa nós não trazíamos. Assim como para a nossa família, também para as que lá ficaram o impacto foi profundo. O desespero do velho vaqueiro, sempre amigo e companheiro, que com as mãos na cabeça chorava andando sem rumo sob as árvores do pomar, externava a dor dos que ficavam. A vida precisou ser reinventada. Para uns, restava o sonho. Para outros, ficava a floresta. Emergindo, agora, das sombras dessas águas profundas, de onde escuto seus murmúrios, retorno ao vento. Tomo fôlego, o poeta segura a minha mão e sussurra ao meu ouvido:

\author{
Alma Natureza \\ A luz seduz de vida a natureza \\ E a vida vela iluminando as trevas \\ Pra que tenhamos nossa alma acesa. (BAIANO, 2008, p. 126)
}

Chegamos a Brasília em pleno período de ditadura militar e, além dessa irmã mais velha, também outros dois irmãos tinham envolvimentos com a educação popular, movimentos sociais e partidos políticos que naquele momento eram considerados clandestinos. Hoje entendo que estas participações eram provenientes da postura de toda a família de contrapor-se às injustiças sociais e de desejar melhores condições de vida para todos. Foram ensinamentos herdados dos nossos pais que sempre tiveram uma relação 
cuidadora e envolta de sentimentos com os trabalhadores da fazenda Roma, mas herdados, principalmente, da convivência intensa, e de muitos amores, com essa comunidade. Ensinamentos que, aos poucos, foram se ampliando e se transformando em compromisso com toda a sociedade.

As primeiras escolas onde estudei, em Brasília, refletiam as contradições postas pelo projeto educacional empreendido pelos militares: instalações precárias, salas de aula superlotadas e multisseriadas, ausência de espaços adequados para atendimento a crianças na idade de 7 a 14 anos. Não havia quadras de esportes, nem espaços apropriados para recreação, nem salas de leitura, o que havia era escassez de material básico para os professores desenvolverem suas aulas e de estrutura para uma educação de qualidade. As minhas leituras de mundo se conflitavam com as leituras dessas escolas. Convivíamos em meio a uma mescla de elementos, como afirmaria Libâneo (2003), da pedagogia tradicional, com discurso da renovada e as imposições do tecnicismo educacional. Este último, principalmente, respaldado pela Lei $n^{\circ} 5.692 / 1971$.

Ingressei no "20 Grau", em 1975, no Centro Educacional Taguatinga Sul, em Taguatinga-DF, onde optei pelo ensino técnico em magistério e, em março de 1981, iniciei a graduação no curso de Licenciatura Plena em Letras Vernáculas pela Universidade Federal de Goiás, em Goiânia. Cidade acolhedora onde constituí família e continuo residindo. Essas formações, aliadas a duas especializações: uma em Metodologia do Ensino da Literatura e outra em Psicopedagogia direcionaram e aprofundaram minha atuação profissional nos caminhos da educação.

Em 1984 iniciei minha carreira na rede Estadual de Educação de Goiás e em 1985 na Rede Municipal de Educação de Goiânia. Desde 1988, atuei no ensino noturno e me identifiquei com essa demanda de trabalhadores alunos, a maioria de nordestinos. Nessa atuação, fui percebendo os passos e os descompassos da relação da escola com a vida dos trabalhadores alunos e desses com a escola. Uma relação permeada de dificuldades e enfrentamentos. As experiências vividas foram suscitando indagações e revelando que prevalecia um modelo de escola tradicional e tecnicista que não os comportava. O currículo, a avaliação, o material didático, a qualidade da aula, a evasão, as escutas, os diálogos, as participações eram aspectos que precisavam ser cuidadosamente repensados, se quiséssemos assumir o compromisso de um trabalho significativo para a vida desses trabalhadores alunos.

Essas inquietações me levaram a tomar a proposta para Educação de Jovens e Adultos da Rede Municipal de Educação de Goiânia como objeto de investigação e, em 2006, finalizei o Mestrado em Educação na Pontifícia Universidade Católica de Goiás (PUC-Goiás), na linha 
de pesquisa: Educação Escolar e Sociedade. Esses estudos proporcionaram crescimento acadêmico e profissional e reafirmaram meu compromisso com a educação, sobretudo com a construção de uma educação transformadora voltada para os jovens e adultos trabalhadores.

Em 2004, iniciei participação no Fórum Goiano de EJA, que possibilitou meu encontro com diversas experiências vivenciadas na luta por uma educação específica e por políticas públicas para essa modalidade em Goiânia, no Estado de Goiás, no Brasil e no mundo. Essa participação me fez pertencente a um movimento em defesa dos interesses dessa modalidade de educação. E, em janeiro de 2011, por aprovação em processo seletivo, ingressei no Projeto de Pesquisa do Centro Memória Viva (CMV): Documentação e Referência em EJA, Educação Popular e Movimentos Sociais, coordenado pela professora Dra Maria Margarida Machado, na Faculdade de Educação da UFG.

A participação no CMV, além de estudos nos seus três eixos de abrangência, proporcionou-me também experiência com documentação. Desde a coleta até a classificação, análise e arquivo, com estudos e discussões sobre as técnicas e normas arquivísticas e os entrelaçamentos com a metodologia da pesquisa científica. Os subprojetos com os quais me encontro mais diretamente envolvida nessa pesquisa são o proveniente da parceria com a SME, "Educação de Jovens e Adultos (EJA) na Secretaria Municipal de Educação de Goiânia: história e memória", e o do fundo de documentação resultante da pesquisa de doutorado da professora Maria Emilia de Castro Rodrigues. A sua tese intitulada: "Enraizamento de Esperança": As bases teóricas do Movimento de Educação de Base em Goiás (GOIÂNIA, 2008) é um estudo sobre educação popular que me envolveu para a discussão do tema do projeto que apresentei a este programa: A Educação Ambiental na Alfabetização de Trabalhadores de Cooperativas de Resíduos Sólidos: por um resgate de elos submersos.

Essa trajetória, aqui transcorrida, traz com ela a memória das minhas águas, mas, na medida em que fazia os registros, fui me dando conta do valor do registro de nossas memórias, percebi que a minha história tem pegadas na história da humanidade e que a história da humanidade é feita pela trama do entrelaçamento de nossas próprias histórias. Vendo dessa maneira, compreendi que não sou mera espectadora da história da humanidade, como me ensinaram nas escolas onde estudei. Com minha mãe, aprendi a lida da luz do sol e, com meu pai, a ver estrelas na escuridão da noite e assim me vejo fazendo história, entre luzes e sombras, pisando firme e sonhando alto. A experiência desta escrita ampliou a compreensão do pertencimento e impregnou de sentido a minha corresponsabilidade social, evidenciando que somos sujeitos das nossas histórias, me fazendo resgatar a história da humanidade sob o 
olhar de quem a vive e faz. Entendo que hoje, talvez mais que antes, essa história precisa ser recontada, agora, sob o prisma dos que a fazem, a fim de que todos se percebam sujeitos e corresponsáveis pelo mundo que construímos. Assim, fica registrada a forma como transcorre o meu pertencimento ao mundo e os vínculos ao tema que apresento.

Por este meio, demonstro meu envolvimento com a educação popular abarcando a educação ambiental, num reencontro profundo com minhas próprias águas, buscando fazer uma discussão nova nesse universo. Uma discussão que seja capaz de conceber uma contribuição para a área científica em que se situa, mas, especialmente, aos catadores alfabetizandos, sujeitos envolvidos no campo da pesquisa. Justifico assim a minha pretensão ao Curso de Doutorado em Educação oferecido pela UnB, devido à confluência na Linha de Pesquisa: Educação Ambiental e Educação do Campo - EAEC.

Figura 2 - Minha mãe de leite no canavial da fazenda Roma

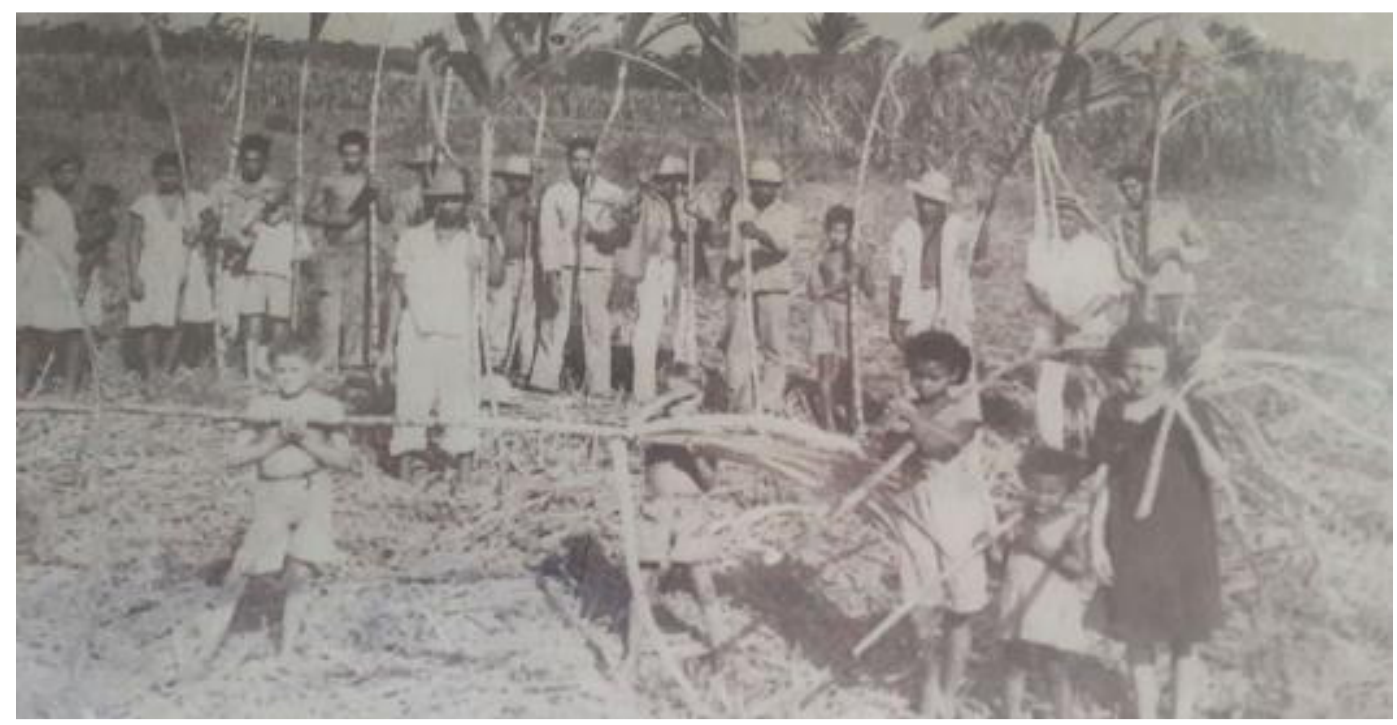

Fonte: Acervo da família Castro Gomes. Década de 1940.

Figura 3 - Mangueira do quintal de Roma

Figura 4 - A ciranda das águas do reencontro
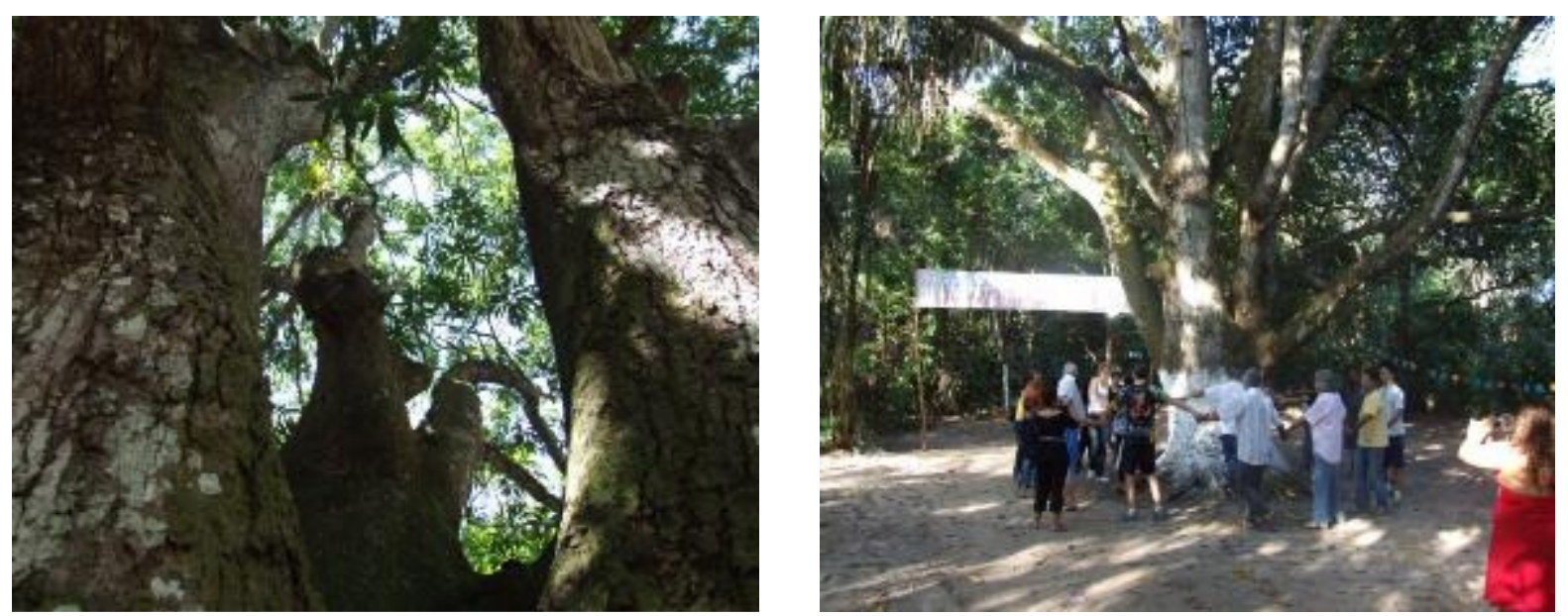

Fonte: Acervo Dinorá de Castro Gomes. Julho de 2010. 


\section{INTRODUÇÃO: LANÇANDO-ME EM ÁGUAS PROFUNDAS}

A imagem do planeta Terra azul vista pela primeira vez na década de 1960, quando o homem cruzou a órbita terrestre, causou perplexidade, emoção e uma profunda consciência de que estamos em uma única comunidade: a comunidade do planeta Terra. Porém, enquanto uns olhavam admirados para aquela imagem, outros com o dedo em riste apontavam para os botões das bombas de destruição em massa que ameaçavam o planeta. Era a guerra fria e as intimidações ensandecidas aterrorizavam. A humanidade, então, vendo-se diante desses prenúncios, retoma antigas indagações: O que é a vida? Quem somos nós? Por que estamos aqui? O que estamos fazendo aqui? Qual o sentido da vida? O que é ciência? Qual a finalidade das descobertas científicas? Para que e para quem serviria a ciência? Essa conjuntura colocou em xeque o sentido das tecnologias, das pesquisas, das descobertas, assim como a busca de maior compreensão da condição humana, exigindo uma nova forma de vinculação com a vida e com o mundo.

Mais uma vez os homens, desafiados pela dramaticidade da hora atual, se propõem a si mesmos como problema. Descobrem que pouco sabem de si, de seu "posto no cosmos" e se inquietam por saber mais. Estará, aliás, no reconhecimento do seu pouco saber de si uma das razões desta procura. Ao se instalarem na quase, senão trágica descoberta do seu pouco saber de si, se fazem problema a eles mesmos. Indagam. Respondem, e suas respostas os levam a novas perguntas. (FREIRE, 1987, p. 29, grifos do autor)

A década de 1960 foi um período de grande impacto para a humanidade. A ameaça imposta ao planeta Terra dizia a todos que outra lógica urgia. Que o homem precisava direcionar seu conhecimento para a vida e não mais para a morte. Ao olhar emocionado para o planeta, impregnado de indagações, o homem olhava para si mesmo e, conforme Gutiérrez e Prado (2000, p.30), compreendeu que as noções de tempo, espaço, matéria, força não podiam mais ser meras categorias isoladas, mas entidades entrelaçadas e integrantes das relações da vida. Confiantes de que outro mundo é possível, esses autores dizem que

Frente à lógica que nega o sagrado e a subjetividade e, em nome do desenvolvimento e do progresso, saqueia a natureza e mata a vida, o paradigma emergente caracteriza-se pela promoção de uma lógica relacional e auto-organizacional que leva o ser humano a redescobrir o lugar que the corresponde dentro do conjunto harmonioso do universo. Abandonar o paradigma que presidiu nosso agir até o momento significa, por isso, apoderar-se de espaços inéditos que requerem novas respostas em todos os âmbitos: político, econômico, cultural, educativo e outros. (2000, p. 30) 
Se a mudança se faz necessária, a educação constitui a base para essa transformação e será maior essa possibilidade quanto maior for o compromisso dos que nela atuam. Pois estar no planeta Terra significa, cada vez mais, tornar-se corresponsável por sua existência, manifestar-se contra as injustiças e lutar pela qualidade de vida para todos. Sensibilizar-se e emocionar-se com a dor e a alegria, no empenho de transformar em realidade a utopia de um mundo melhor, construído entre o belo e a iniquidade sob o azul que nos envolve. A educação, em seu sentido mais amplo de formação humana, deve favorecer a conscientização sobre a urgência de salvaguardar o planeta Terra e garantir a sustentabilidade de 15 bilhões de anos de trabalho para que a vida humana se tornasse possível.

\section{CONSIDERAÇÕES INICIAIS: ÁGUAS QUE FERTILIZAM O CAMPO}

A década de 1960, envolvida em sentimentos de rebeldia e insatisfação, em virtude dos acontecimentos históricos, é marco da emergência de um movimento de mobilização e contestação social, de busca de novos valores. Chamado de contracultura, esse movimento apresentava um caráter universal de mudança de atitude e integração cultural e humana, protesto político, tomada de consciência. As ideias marxistas e as existencialistas, lado a lado, subsidiando e fortalecendo organizações e lutas. A partir dessa década, eclodiram os movimentos e as ações que estavam sendo construídos por quem acreditava na realização da utopia de um mundo melhor, justo e humano, onde todos pudessem viver com dignidade e reconhecidos como cidadãos de direitos.

As sociedades do Hemisfério Norte pulsavam ao compasso da expansão financeira e cultural. A abertura para as alteridades terceiro-mundistas, étnicas e de gênero agudizou as contradições e instalou a luta pelas liberdades e possibilidades de autonomia que pareciam realidades muito próximas para os que fizeram e viveram a contracultura naqueles anos. Poder-se-ia dizer que foram anos de utopia e ousadia, embalados por uma visão romântica da revolução radical e da contestação à ordem e às disciplinas limitantes do potencial humano e social com o qual se podia sonhar. (CARVALHO, 2011, p.47)

É esse o contexto que promove o surgimento da Educação Popular, o mesmo de onde emanam as questões ambientais e, posteriormente, na década de 1970, a Educação Ambiental. A crise do desenvolvimentismo industrial e a iminência de uma terceira guerra mundial, durante a guerra fria imposta ao planeta Terra, diziam a todos que outra lógica urgia. 
A tese de Carson de que estávamos nos submetendo ao lento envenenamento pelo mau uso de pesticidas químicos que poluíam o meio ambiente pode parecer trivial agora, mas em 1962 Primavera Silenciosa concentrava o cerne da revolução social. Carson escreveu em um tempo de nova abundância e de intenso conformismo social. A Guerra Fria, com seu clima de suspeição e intolerância, estava em seu zênite. A indústria química, uma das principais beneficiárias da tecnologia do pós-guerra, era também uma das principais autoras da prosperidade nacional norte-americana. (LEAR, 2010, p.11)

Em sintonia com esse efervescente contexto, a pesquisa que apresento, a partir do acoplamento entre Educação Ambiental (EA) e Educação Popular (EP), procura investigar os elos existentes entre esses campos do saber, como essa relação se efetiva e quais os conhecimentos que daí podem ser revelados. A experiência de alfabetização de adultos, junto ao Programa AJA-Expansão ${ }^{1}$ da Secretaria Municipal de Educação de Goiânia (SME), com trabalhadores das cooperativas de resíduos sólidos, converge para esse desafio e constitui o meio empregado para observarmos como essa relação pode acontecer. Busca-se, portanto, uma ação comprometida com a transformação do ser e da sociedade, com a expansão do conhecimento, com a liberdade. Para isto, é necessária uma concepção de Educação Popular e de Educação Ambiental que possibilite essa sustentação no contexto atual da sociedade, considerando-se as circunstâncias proporcionadas pela cidade de Goiânia, as condições dadas pelo programa AJA-Expansão e a realidade vivida nas cooperativas de resíduos sólidos, como os principais elementos constitutivos dessa relação.

O analfabetismo no Brasil é uma pegada deixada nas areias da nossa história colonialista construída nas relações entre os que aqui habitavam, os que foram trazidos da África e os colonizadores europeus. Desde o início do período colonial, com as ações evangelizadoras dos jesuítas, muitos têm sido os programas e as iniciativas, com as mais diversas concepções e interesses que, de tempos em tempos tentam atender essa demanda. A partir da década de 1960, com o trabalho politizador de alfabetização de adultos realizado por Paulo Freire, ficou ainda mais evidente que o analfabetismo traz consigo muito mais que apenas um grupo de pessoas que não teve a oportunidade de aprender a ler e a escrever. Ele, hoje, mais que antes, é um estigma, é, sobretudo, uma expressão das pegadas deixadas não somente pelos que defendiam seus próprios interesses, mas pela força dos que ainda agem

\footnotetext{
1 O "AJA-Expansão" é um programa de alfabetização de adultos da SME de Goiânia que nasceu do compromisso do governo municipal, gestão 2001 - 2004, com a demanda de analfabetos de 15 anos de idade ou mais, existente na cidade de Goiânia. É a única iniciativa em rede pública voltada para a alfabetização de adultos nessa cidade.
} 
priorizando seus valores. Grupos que lutam pelo poder, mas que não conseguem fazer um diálogo próximo e verdadeiro com essa realidade.

Presente na sociedade, essa demanda oculta, portanto, jogos de interesses das mais diversas naturezas: econômicos, quando considerados dispendiosos; políticos, quando usados pelos truques ilusionistas dessa arte; sociais, ao se tornarem um problema pelas ruas das cidades; humanos, ao serem vistos como pessoas de direitos. Assim, muitas têm sido as iniciativas que se voltam a essa demanda, com o surgimento de programas federais, estaduais e municipais sem, contudo, obterem êxito. A grande demanda de pessoas adultas que não sabem ler e escrever continua existindo e tornou-se um aspecto da sociedade brasileira incorporado à sua natureza, vivido por muitos, ignorado por uns e naturalizado por outros.

É preciso pensar a formação humana e a formação do cidadão crítico, mas o sentido profundo dessa formação dificilmente se efetivará se não estiver inserida na Educação Ambiental, portanto à noção do todo "interdependente" e "interativo". Vendo dessa maneira, outras indagações me habitam: como pensar um cidadão capaz de cuidar de si, do outro e da sociedade sem uma ecocompreensão do mundo, sem a percepção das relações que permeiam as vidas no planeta? Como pensar um programa de educação, especialmente de alfabetização de adultos, sem levar em consideração que todos somos constitutivos de um mesmo meio ambiente? Como vislumbrar um futuro desejável, sem reflexões e atitudes ambientais? Da mesma forma, mediante o campo que aqui se configura, podemos ainda indagar: Como a educação popular pode trazer novos sentidos para a educação ambiental?

O cidadão crítico e consciente é aquele que compreende, se interessa, reclama e exige seus direitos ambientais ao setor social correspondente e que, por sua vez, está disposto a exercer sua própria responsabilidade ambiental. Este cidadão, quando se organiza e participa na direção de sua própria vida, adquire poder político e uma capacidade de mudança coletiva. Esse princípio assenta bases sólidas para a construção da sociedade civil, pois são os movimentos sociais, no redimensionamento de sua participação social, os que podem validar o processo para gestar uma utopia de qualidade de vida alternativa, que se atualiza no cotidiano e dentro de um horizonte futuro, desejável e viável. (GUTIÉRREZ; PRADO, 2000, p. 15)

A experiência com a alfabetização de adultos, trabalhadores de cooperativas de catadores de resíduos sólidos em Goiânia, realizada para esta pesquisa, mergulha nesse pântano com as estratégias da EA e, com suas lentes, busca apreender como essa situação se apresenta hoje na sociedade, promovendo um encontro com a EP. A EA e a EP possuem domínios peculiares que, academicamente, os constituem como campos epistemológicos. Conforme Canesin (2002, p. 99): 
Os campos são espaços de produção de bens simbólicos permeados por relações de poder expressas em conflitos, lutas, consensos entre os diversos agentes que, dispostos hierarquicamente, disputam o domínio destes bens como forma de autoridade, legitimidade e prestígio.

A submersão feita nesse ambiente, por meio da pesquisa realizada, traz à superfície dessas águas o murmúrio dos diálogos que se constituem no amálgama desses campos. Embora nasçam nas mesmas fontes e compartilhem de uma mesma realidade, surgem isoladamente nos programas e nos projetos educacionais, como se constituíssem aspectos de diferentes realidades. A experiência realizada indicou que as lutas e os conflitos não nascem desse amálgama, elas surgem das relações de confronto com as forças conservadoras e desarticuladoras dos movimentos sociais contra as quais a EA e a EP se posicionam do mesmo lado.

\subsection{Goiânia: um contexto em muitas águas}

Goiânia, hoje com 82 anos, é uma cidade localizada no planalto central brasileiro, criada para ser a capital do Estado de Goiás. Nascida no meio do cerrado goiano é um desdobramento do movimento histórico das entradas e bandeiras, que iniciou o povoamento dessa região na busca de metais e pedras preciosas, no apresamento de indígenas e na captura de escravos africanos fugitivos. Goiânia atualmente é uma metrópole com grandes desafios a serem superados ${ }^{2}$. Cidade com maior concentração de renda da América Latina, segundo relatório 2008/2009 ONU-Habitat, grandes e luxuosos condomínios contrastando com as favelas das muitas posses urbanas; possui quase um automóvel para cada adulto com carteira de habilitação e a maior frota de moto do país, nas ruas da cidade; é a $17^{\mathrm{a}}$ cidade mais violenta do Brasil. Com 1.403.697 habitantes, segundo IBGE, Censo 2015, é a segunda cidade mais populosa do Centro-Oeste, superada apenas por Brasília. O poeta goiano José Mendonça Teles (2005, p.28) extrai em seus versos gotas dos sentimentos da minha alma goiana. "Eu te vejo, Goiânia, quando abro a janela de minha sensibilidade e sinto a sensação de que o tempo, preso na tessitura de meus dedos, caminha comigo e me faz protagonista de tua história".

Goiânia, com um farto manancial, é permeada por muitas águas ${ }^{3}$. Possui 85 cursos d'água, sendo: 4 ribeirões (Anicuns, João Leite, Capivara e Dourados); 1 rio (Meia Ponte) e

\footnotetext{
${ }^{2}$ Disponível em: <www.encontragoiania.com.br/goiania>. Acesso em 10 mar. 2013, às 16h.

3 Fonte: Agência Municipal do Meio Ambiente - Goiânia (AMMA). Disponível em: <www.goiania.go.gov.br/shtml/amma/r>. Acessado em: 09 abr. 2014, à 1h.
} 
80 córregos. Os principais problemas verificados nos mananciais da capital, hoje, são ausência de mata ciliar, lançamentos clandestinos de esgoto, lançamentos clandestinos de entulho, focos de erosão, assoreamento e a ocupação irregular da Zona de Proteção Ambiental (ZPA). A Agência Municipal do Meio Ambiente (AMMA) possui projeto de limpeza das nascentes e reflorestamento da mata ciliar, que vem desenvolvendo de forma bastante precária, por falta de estrutura adequada para uma atuação mais eficiente.

Goiânia possui um índice de analfabetismo de 3,3\% da população, pessoas de 15 anos ou mais, de acordo com o Censo $2010^{4}$. Embora esteja bem abaixo da média nacional, é um índice expressivo, corresponde acerca de 46.322 habitantes. Contrastando com a beleza das flores de seu paisagismo urbano estão a desigualdade social, os problemas de trânsito, além do elevado índice de criminalidade. O clima seco, em grande parte, está associado ao desmatamento da mata original e à poluição do ar, provocada pela grande frota de automóveis. Inclui-se ainda a luta histórica pela superação do analfabetismo e por uma educação pública de qualidade, acolhedora das divergências e integradora das diversidades.

É, portanto, na conjuntura dessa cidade que, de maneira muito específica, com foco nas cooperativas de resíduos sólidos, resultantes da coleta seletiva em toda a cidade, que busco, por meio da relação entre a Educação Ambiental (EA) e a Educação Popular (EP), alcançar uma atuação capaz de apontar para uma alternativa que traga resultados diferentes ao processo de alfabetização e formação humana. Compreendendo a EA como resultante da reflexão da sociedade contemporânea sobre os efeitos da intervenção do homem na natureza e da administração dos riscos socioambientais, o que demandam um aumento do nível de consciência ambiental dos cidadãos para a construção de sociedades sustentáveis ${ }^{5}$. E compreendendo a EP como um atendimento específico originado para atender a alfabetização de adultos, de acordo com os preceitos da educação libertadora de Paulo Freire. Um entendimento que percebe tanto a EA quanto a EP entrelaçadas com os movimentos sociais, comprometidas com a justiça socioambiental e voltadas para a defesa do direito de todos pela qualidade de vida.

\footnotetext{
${ }^{4}$ Disponível em: <www.censo2010.ibge.gov.br>. Acesso em: 10 mar. 2013, às 17 h e 30 min.

${ }^{5}$ Segundo o relatório Brundtland (1991, p. 9) "A humanidade é capaz de tomar o desenvolvimento sustentável - de garantir que ele atenda as necessidades do presente sem comprometer a capacidade de as gerações futuras atenderem também às suas". Sustentabilidade tornou-se, então, um termo para definir ações e atividades humanas que visam suprir as necessidades atuais dos seres humanos, sem comprometer o futuro das próximas gerações. Ou seja, a sustentabilidade está diretamente relacionada ao desenvolvimento econômico e material sem agredir o meio ambiente, usando os recursos naturais de forma inteligente para que eles se mantenham no futuro.
} 
Figura 5 - Contrastes de Goiânia

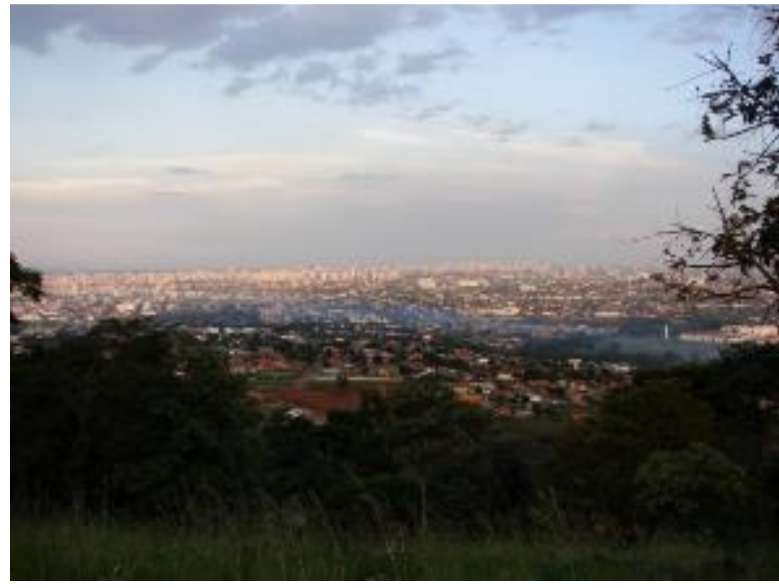

Fonte: internet - skyscraperlife.com. Abril de 2016.
Figura 6 - Rua lateral da Acop - Goiânia

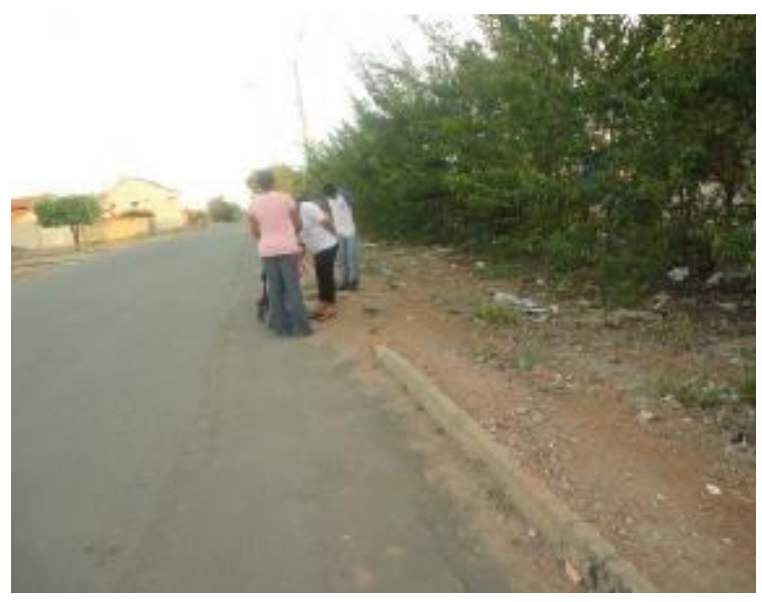

Fonte: Acervo da pesquisa. Outubro de 2014.

\section{JUSTIFICATIVA: SEIVA DA NASCENTE}

Vislumbro, com base na caminhada percorrida, a carência de produção acadêmica que apresente uma discussão da Educação Ambiental inserida nos procedimentos da Educação Popular, demonstrando a proximidade ou buscando o diálogo na relação entre esses dois campos. Essa situação enfatiza o valor deste estudo, pela possibilidade de suscitar novos elementos para a efetivação do direito de todos a uma educação de qualidade, especialmente dos adultos em nível de alfabetização das cooperativas de resíduos sólidos. Todavia enfatiza também por dar voz a uma discussão que, embora esteja colocada em pauta, é tomada como se os aspectos ambientais se resolvessem por si próprios, ou fossem insignificantes, mediante a resolução de outros problemas.

A observação que se faz é de que há um entendimento reduzido e aligeirado, predominante, acerca da EA. Um juízo que a coloca distante das discussões de currículo, avaliação e políticas públicas como se essas também não perpassassem pela discussão da Educação Ambiental. É, portanto, com o entendimento de uma EA entranhada na educação em geral e em nome do compromisso com a efetivação da educação como um direito e de qualidade para todos que busco, por meio desta pesquisa acadêmica, caminhos alternativos para maior aproximação das exigências de uma demanda específica de escolarização de nossas comunidades e da sociedade. É uma parte da ciência que se ocupa com a construção de uma sociedade mais justa e mais humana.

A discussão em torno do analfabetismo e da educação de jovens e adultos, compreendida como um direito e ao longo da vida, leva-nos a um olhar retrospectivo, à construção de um diagnóstico da situação atual e a uma visão dos desafios, especialmente 
quando transversalizada pela Educação Ambiental. Essa confluência de perspectivas permite a abrangência de grande parte do universo da Educação Popular, onde é flagrante o insucesso das políticas públicas frente às metas de superação do analfabetismo. Acredito, no entanto, que a transversalização da EA amplia as possibilidades de aproximação desse universo a cada realidade, podendo facilitar a criação de uma EP específica, própria dessa comunidade de trabalhadores de cooperativas de catadores de resíduos sólidos, trazendo a leitura desse mundo, na leitura das suas palavras, para outras leituras de outros mundos.

As estratégias da EA buscam um caminho integrador conduzindo à religação do homem à natureza e, ao percorrer esse caminho ao longo da pesquisa realizada, ela fez emergir com nitidez a fragmentação tão presente nos procedimentos educacionais comumente adotados. De tal modo, pude perceber com maior clareza o quanto a educação está impregnada pela fragmentação e o quanto que vamos imergindo nessas águas, até que as sombras nos retire a visão. E a EA nos dá fôlego para perceber que, na verdade, está fragmentada não somente a educação, mas toda a sociedade em sua maneira de se organizar e de se relacionar com a vida. Desse modo, educação e sociedade caminhando juntas, com os cacos de uma alimentando os fragmentos da outra.

O amálgama da relação entre a EA e a EP, nascido na experiência de alfabetização de uma turma de catadores de resíduos sólidos em Goiânia, origina um estudo de significativo valor por trazer à superfície uma realidade que repousa na sombra das águas profundas: a permanente demanda de catadores que não sabem ler e escrever. Uma demanda que pressupomos estar vinculada à história e ao modelo socioeconômico do país, assim como ao abandono a que essa realidade se encontra. A natureza integradora da EA é fonte nova para essas águas que chega articulando a educação libertadora de Freire (1987), com o pensamento transdisciplinar de Nicolescu (1999), o método da complexidade de Morin (2008) e a biologia do amor de Maturana (2009).

A alfabetização é um processo multirreferencial e multidimensional, pois envolve diversos aspectos sociais, mas, especialmente, envolve múltiplos aspectos da vida e da subjetividade humana. A maneira peculiar como cada alfabetizando viveu o seu processo de aprendizado das habilidades de leitura e escrita, manifestada durante a experiência realizada com os catadores, é uma evidência determinante de que a alfabetização é, sobretudo, uma vivência subjetiva. A partir dessa constatação, imersa na experiência realizada, intuo, ainda, que todos têm a capacidade de serem alfabetizados, desde que sejam valorizados e respeitados o tempo e o espaço de cada ser. Sendo assim, somente um procedimento de alfabetização 
enraizado na vida cotidiana é capaz de contribuir com o processo emancipatório desses catadores.

\section{QUESTÕES QUE EMERGEM DA FORÇA DAS ÁGUAS}

* Qual a contribuição da Educação Ambiental para uma aprendizagem significativa na alfabetização de adultos trabalhadores de cooperativa de resíduos sólidos?

* De que forma as estratégias ecopedagógicas podem contribuir para a formação humana emancipatória de alfabetizandos trabalhadores de cooperativas de resíduos sólidos?

\section{OBJETIVO GERAL: AO ENCONTRO DAS ÁGUAS CORRENTES}

Analisar a contribuição da Educação Ambiental para alfabetização e formação humana junto a uma turma de trabalhadores em cooperativas de resíduos sólidos na cidade de Goiânia.

\section{OBJETIVOS ESPECÍFICOS: ÁGUAS EM MOVIMENTOS CONEXOS}

* Inserir a EA, como tema gerador e transversal, em uma turma de alfabetização de trabalhadores de cooperativas de resíduos sólidos;

Desenvolver estratégias transdisciplinares, integrando conhecimentos e a complexidade do indivíduo contribuindo para a aprendizagem significativa e a expansão do ser;

Desenvolver atividades ecopedagógicas como estratégias de alfabetização.

\section{ESTRUTURA DA TESE: ÁGUAS INVENTANDO CAMINHOS}

A pesquisa-ação busca estreitar a sintonia entre o empírico e o teórico, explicando que o rigor "repousa na coerência lógica e empírica" (BARBIER, 2007, p. 60). Com esse cuidado, esta pesquisa está organizada em cinco capítulos construídos à luz das questões que a originam e dos objetivos propostos. Um percurso transcorrido no exercício desafiador da coerência. Com essa intenção, o primeiro capítulo apresenta o contexto histórico que deu origem à EA e à EP, identificando os seus fundamentos e possíveis vínculos e procurando situá-los na conjuntura atual da educação.

O segundo capítulo trata da memória da educação de adultos na rede municipal de educação de Goiânia por haver em sua proposta uma opção tomada em adotar a concepção da 
EP em seus princípios e procedimentos didático pedagógicos. A abordagem feita abrange a trajetória do Programa AJA-Expansão por ser o Programa responsável pela alfabetização de adultos nessa rede, com mais de 10 anos de existência.

O terceiro capítulo expõe a metodologia e suas lentes conceituais. Ele diz respeito às diferentes maneiras como podemos nos aproximar do objeto de conhecimento. Sabemos que essas escolhas não são aleatórias, elas vêm, portanto, trazidas pelo referencial teóricometodológico que dá sustentação ao trabalho de pesquisa e à análise interpretativa dos resultados. Estes referenciais foram escolhidos a partir da proposta de confluência da educação ambiental com a educação popular e alguns autores trazem uma contribuição substancial para este trabalho, dentre eles: Freire, Brandão, Leff, Morin, Nicolescu, Maturana, Carvalho.

O quarto capítulo é dedicado a apresentar as cooperativas em Goiânia e no Brasil, como uma forma de organização popular alternativa de compartilhar coletivamente os bens e serviços. O histórico, a relevância, a força de mudança trazida por essa organização, num mundo orientado pela lógica de mercado, pelo lucro. Apresenta as cooperativas em Goiânia, vinculadas à Incubadora Social da UFG, suas trajetórias e contextos, buscando conexões com a EA, a partir da pesquisa realizada, como espaços de interlocução entre a EA e a EP.

O quinto capítulo é o mar do encontro das águas movimentadas na experiência realizada. Nesse capítulo faço a descrição do percurso metodológico e também a análise interpretativa dos dados, buscando responder as questões da pesquisa. Nele, a experiência vivida ao longo do processo de alfabetização é detalhadamente abordada, à luz do objetivo descrito, fazendo emergir algumas categorias da cotidianidade da experiência realizada, balizadoras dos resultados obtidos e do desencadeamento de novas ações.

As considerações finais proporcionam a oportunidade de retomar alguns pontos relevantes da pesquisa num esforço de fazer conexões com as questões e objetivos da pesquisa, num encontro de águas sob a luz da experiência realizada na turma de alfabetização de trabalhadores das cooperativas de catadores. Nessas considerações se evidenciam os aspectos atuais e peculiares apresentados, assim como os possíveis desdobramentos desses resultados para o contexto contemporâneo. Por se tratar de uma pesquisa qualitativa, da área das ciências humanas e, especialmente, oriunda da Educação Ambiental, esse espaço traz também as lacunas da incompletude geradoras de novas indagações. 


\section{Capítulo 1}

\section{A natureza das águas que conduzem para a confluência}

\section{da educação ambiental com a educação popular}

Figura 7 - Águas da confluência

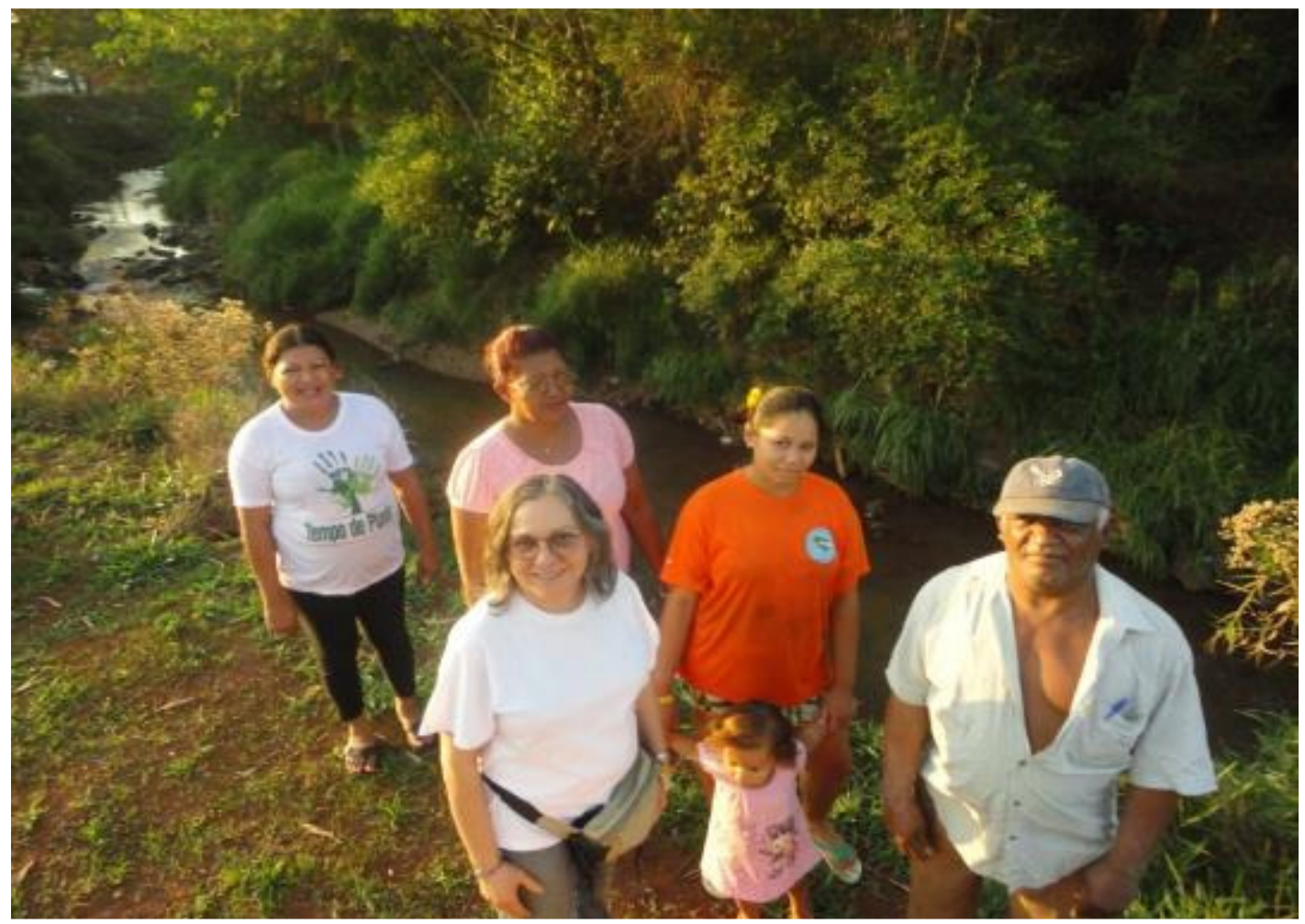

Fonte: acervo da pesquisa. Catadores às margens do córrego Cascavel. Outubro de 2014. 


\title{
CAPÍTULO 1 - A NATUREZA DAS ÁGUAS QUE CONDUZEM PARA A CONFLUÊNCIA DA EDUCAÇÃO AMBIENTAL COM A EDUCAÇÃO POPULAR
}

\author{
“Antes das aulas a gente passava \\ por cima do córrego \\ e nem olhava pra baixo. \\ Até das plantas mesmo também. (...) \\ Fez mudar dentro de mim, \\ porque agora eu tenho cuidado com as plantas. \\ Antes eu não tinha mesmo não. \\ Eu nem ligava, mas agora não, agora eu tenho."
}

Maria P

\subsection{Introdução: águas ruidosas da Educação Ambiental e da Educação Popular lançadas em uma experiência de aprendizagem significativa na alfabetização de adultos catadores}

O campo da Educação Ambiental é o lugar de onde se origina este estudo, um campo que precisa se lançar em outros espaços temáticos da educação e demonstrar sua capacidade de transformar a realidade e contribuir na construção de uma aprendizagem significativa. No diálogo com a Educação Popular essa chance é ainda maior, pois ambos compartilham da mesma luta por um mundo melhor e mais justo, todavia mais integrado e mais conectado às forças reparadoras da natureza.

A EA, como suporte desta pesquisa, traz referenciais com implicações específicas vinculadas à sua própria definição. Essas implicações, acopladas à definição da EA, por sua vez, vão se modificando, pois o conceito de EA é vinculado ao conceito de meio ambiente, portanto, na medida em que vai se modificando a compreensão de meio ambiente, também a de EA vai se refazendo. O meio ambiente compreendido, de maneira reduzida, envolvendo exclusivamente a seus aspectos naturais, restringe a percepção da interdependência entre as partes que constituem o todo e em contínuo movimento dialético. O conceito de EA elaborado como suporte para a preparação da Rio-92, amplia o olhar acerca do meio ambiente, ampliando também a visão da EA. Dias (2003, p. 99) nos apresenta esse conceito:

Nos subsídios técnicos, elaborados pela Comissão Interministerial para a preparação da RIO-92, a EA se caracterizava por incorporar a dimensão socioeconômica, política, cultural e histórica, não podendo basear-se em pautas rígidas e de aplicação universal, devendo considerar as condições e o estágio de cada país, região e comunidade, sob uma perspectiva holística. Assim sendo, a EA deve permitir a compreensão da natureza complexa do meio ambiente e interpretar a interdependência entre os diversos elementos 
que conformam o ambiente, com vistas a utilizar racionalmente os recursos do meio, na satisfação material e espiritual da sociedade, no presente e no futuro. (Grifos do autor.)

O Conceito de EA apresentado por essa Comissão conduz, portanto, a um olhar abrangente, a partir do qual se pode compreender outros sentidos para os conhecimentos que a EA se propõe a desenvolver. Para o alcance de seus propósitos, em "permitir a compreensão da natureza complexa do meio ambiente e interpretar a interdependência entre os diversos elementos que conformam o ambiente", Dias (2003 p. 99) ela precisa ser uma educação significativa, ou seja, uma educação que perpassa por uma abrangência sistêmica, que "possibilita identificar os diferentes componentes de um sistema ambiental e salientar as relações entre seus componentes". Para Sauvé, (2005, p.22) ela precisa ser holística, ao "levar em conta não apenas o conjunto das múltiplas dimensões das realidades socioambientais, mas também das diversas dimensões da pessoa que entra em relação com essas realidades, da globalidade e da complexidade de seu 'ser-no-mundo"'. Sauvé (2005 p. 27) Precisa perpassar pela "dimensão humana do meio ambiente, construído no cruzamento da natureza e da cultura". Sauvé (2005p. 25). Perpassar por uma noção de sociedade sustentável, em "que o desenvolvimento econômico, considerado como a base do desenvolvimento humano, é indissociável da conservação dos recursos naturais”. Perpassar pela ecopedagogia, que "aproveita a relação com o meio ambiente como cadinho de desenvolvimento pessoal, para o fundamento de um atuar significativo e responsável”. Sauvé (2005 p.35) Perpassar por uma consciência ambiental integradora do homem à natureza, mas integrando-o ao mundo, às suas culturas, às inter-relações entre os seres humanos e seus meios biofísicos.

A conscientização não está baseada sobre a consciência, de um lado, e o mundo, de outro; por outra parte, não pretende uma separação. Ao contrário, está baseada na relação consciência - mundo.

Tomando esta relação como objeto de sua reflexão crítica, os homens esclarecerão as dimensões obscuras que resultam de sua aproximação com o mundo. A criação da nova realidade, (...), não pode esgotar o processo da conscientização. A nova realidade deve tomar-se como objeto de uma nova reflexão crítica. (FREIRE, 1979a, p. 15)

O campo da educação ambiental popular emerge, então, com a força da realidade que o origina e com o desafio de dimensões imensuráveis ao se posicionar na contramão da exploração, da fome, da injustiça, de tudo aquilo, enfim, que atenta contra toda manifestação da vida no planeta. Bases sobre as quais se sustenta a lógica de mercado capitalista assentada 
na compra e venda de produtos retirados da natureza e consumidos desenfreadamente, na obsessão do lucro, enquanto consome o próprio ser condicionando a sua inserção ou exclusão social ao seu poder de pertencimento a esse ciclo consumista.

As águas que envolvem o universo deste estudo me fazem iniciar a sistematização da pesquisa, rompendo seu invólucro, com o contexto atual onde ela se insere. Esse momento se principia, portanto, perpassando pela Educação Ambiental e a Educação Popular, campos do conhecimento que abrigam a experiência realizada. A experiência procura trazer à superfície dessas águas os elos, submersos pela racionalidade cartesiana desagregadora, que podem ser formadores de um novo campo, o campo da educação ambiental popular.

A escuta ao murmúrio dessas águas busca entender a razão pela qual existe uma silenciada compreensão tácita de que a EA e a EP não navegam nas mesmas águas e também o porquê das resistências em entendê-las juntas. Em decorrência dessa percepção elas vêm sendo colocadas em leitos apartados e sacrificando os ganhos que podem haver para a educação, especialmente para a educação e alfabetização dos adultos, embora naveguem no mesmo leito da totalidade integradora da natureza da natureza (MORIN, 2008). Ressaltamos, portanto, que a EA, por meio de suas estratégias ecopedagógicas, procura traçar um percurso de religação entre o todo e as partes, buscando distanciar-se dos elementos fragmentadores do conhecimento e da existência humana. Um percurso que se inicia na ação junto aos sujeitos educandos desde a alfabetização, de crianças, jovens e adultos, à pós-graduação.

\subsection{Contextualização: a natureza das águas}

A experiência desta pesquisa baseou-se em estratégias da EA, apostando em uma mudança de consciência humana e planetária, a partir e com foco nas histórias de vida, em seu contexto ambiental subjetivo, considerando suas diversas dimensões, com a consciência da impermanência, incompletude e complexidade da existência humana. A partir dessa prática eco-didático-pedagógica, portanto, tantas dimensões foram surgindo: da comunitária, social e política, à espiritual, onde o aspecto do sagrado habita. Com essa postura, busquei fazer uma aproximação significativa entre estratégias didático-pedagógicas e uma formação humana integral e transformadora. Com a experiência realizada, passo a concordar com Grün (2007, p. 22-23), entendendo que nós, todos os sujeitos participantes dessa pesquisa, somos hoje indivíduos modificados: 
concepções dominantes de um modo de ser objetificante e antropocêntrico. Para efetivação desses princípios são necessários, como instâncias de realização da educação ambiental, a humildade, o respeito e o diálogo com a Natureza.

As águas onde me lanço movimentam meu empenho em desvendar entendimentos. Nesse sentido, busco definições conceituais que apascentam essas águas, suavizando a travessia. Por conseguinte, emerge dessa nascente a necessidade de compreender o que é Educação Ambiental e o que é Educação Popular. Assim, da margem, avisto as águas e tomo fôlego para lançar-me em um mergulho desafiador em sintonia com a natureza espiralada das buscas, procurando o vórtice das questões que me impulsionam. Com essa intenção, imersa nessas águas, vou remontando a história da EA e da EP, para trazer contextos que expressam o nascimento e a trajetória de compromissos de ambas e a conjuntura atual onde estão inseridas. Entendo que as falas apresentadas, dos sujeitos envolvidos na pesquisa, fortalecem o pensamento inicial acerca dos elos existentes entre esses dois campos e de como esses vínculos se materializam.

A história da humanidade sempre esteve inserida na natureza e os movimentos de uma atingindo os da outra continuamente. A racionalidade que conduziu a trajetória humana desprezou os ciclos da natureza e traçou um percurso que conduz ao esgotamento da vida no planeta. Atualmente, a crise ambiental coloca a humanidade diante de sua própria face, se dando conta de que os limites exploratórios da natureza estão no limite da vida. A escassez de água no planeta é uma resposta, sinalizando o seu esgotamento e a necessidade de outra lógica de relações que não seja guiada pela lógica do mercado. As estratégias de poder oriundas das relações de mercado, sustentadas por uma teoria econômica devastadora, mostra os seus limites.

A ideologia do progresso que promovia o conhecimento objetivando o real,
justificando a realidade, dominando a natureza, impulsionando o avanço da
ciência e da tecnologia, abriu as comportas de um processo de crescimento
econômico que se supunha infinito. De repente, a crise ecológica mostra os
efeitos da racionalidade econômica sobre a degradação ambiental. A lei-
limite do crescimento expressa-se na lei da entropia - a segunda lei da
termodinâmica - que se manifesta nesse transbordamento das externalidades
negativas da economia no aquecimento global do planeta. (LEFF, 2010, p.
23)

As relações de exploração capitalista, assentadas num modelo social devastador do homem e da natureza, têm o seu contorno manifestado em movimentos sociais em todo o planeta, que se acirram a partir da década de 1960. No Brasil, esses movimentos vão 
desencadear em um repensar das iniciativas em educação popular. Esse repensar, além de denunciar uma realidade de injustiça social e de exclusão, onde poucos tinham acesso à educação, traz "um novo enfoque quanto ao conceito de alfabetização, porque não dizer de educação, onde a perspectiva de letramento e decodificação, característica da visão das décadas de 40 e 50, passa a ser associada à concepção política do ato de educar.” (MACHADO, 1997, p. 15) A inserção da dimensão política ao ato de educar gera turbulências nas relações sociais estabelecidas desacomodando o povo e incomodando o poder, com exigências de transformação.

Hannah Arendt (2008, p. 45) fala da inserção do homem na política como um ato de coragem, um ato de deixar a família para dedicar a vida aos negócios da cidade. Explica que, na visão aristotélica, adentrar na política era superar o anseio inato da sobrevivência, era libertar-se da limitação do processo biológico da vida.

$\mathrm{Na}$ raiz da consciência política grega encontramos uma clareza e uma eloquência sem-par na definição dessa diferença. Nenhuma atividade que servisse à mera finalidade de garantir o sustento do indivíduo, de somente alimentar o processo vital, era digna de adentrar a esfera política. (ARENDT, 2008, p. 46)

Vejo que esse entendimento estava implícito no pensamento de Paulo Freire, que via na educação um caminho de libertação da subserviência humana às condições de exploração, que submete a vida à mera sobrevivência. A dimensão política é a via por meio da qual o homem pode libertar-se da opressão e pela educação ele pode ampliar a consciência crítica, resgatar a cultura e emergir compromissado com a sua realidade.

Se a vocação ontológica do homem é a de ser sujeito e não objeto, só poderá desenvolvê-la na medida em que, refletindo sobre suas condições espaçotemporais, introduz-se nelas, de maneira crítica. Quanto mais for levado a refletir sobre sua situacionalidade, sobre seu enraizamento espaço-temporal, mais "emergerá" dela conscientemente "carregado" de compromisso com sua realidade, da qual, porque é sujeito, não deve ser simples espectador, mas deve intervir cada vez mais. (FREIRE, 1979b, p. 61, grifos do autor)

Para Paulo Freire a educação é, sobretudo, um ato político, uma passagem para a libertação da opressão. Com essa visão, ele nos diz em A importância do ato de ler (FREIRE, 2009, p. 11) que "A leitura do mundo precede a leitura da palavra, daí que a posterior leitura desta não possa prescindir da continuidade da leitura daquele. Linguagem e realidade se prendem dinamicamente.” E explica: 
Daí que sempre tenha insistido em que as palavras com que organizar o programa da alfabetização deveriam vir do universo vocabular dos grupos populares, expressando a sua real linguagem, os seus anseios, as suas inquietações, as suas reivindicações, os seus sonhos. Deveriam vir carregadas da significação da sua experiência existencial e não da experiência do educador. (FREIRE, 2009, p. 20)

Concordando com o autor, entendo que a continuidade da leitura do mundo está intrincada pela leitura das relações que permeiam a nossa existência no ambiente que construímos e nas narrativas que registramos. Nesse sentido, vê-se que as pegadas da história construída pela sociedade brasileira são ainda hoje uma marca profunda da exploração e da escravidão que distancia os adultos analfabetos da escolarização. Essa realidade evidencia que vivemos ainda o peso de uma história marcada pela escravidão dos povos africanos e pela exploração e quase dizimação dos povos indígenas, uma relação de opressão enraizada na cultura dessa sociedade e capaz de envolver a todos em uma imagem ideológica de repetição, de acomodação, de naturalização da imobilidade e da exploração sufocando o potencial emancipatório.

Atualmente, a contribuição da Educação Popular tornou-se de grande importância para a definição da perspectiva não somente da alfabetização de adultos, mas de toda a educação pública do país. Tanto assim, que foi constituído um grupo pelo MEC para definir a Educação Popular e elaborar um documento balizador do trabalho com essa educação. Esse documento foi denominado "Marco de Referência da Educação Popular para as Políticas Públicas". Um reconhecimento do país à relevante contribuição da EP e, especialmente, a Paulo Freire, no mesmo ano em que ele foi condecorado como patrono da educação brasileira, pela grande contribuição de seu trabalho à educação do país. Esse Marco apresenta que

a questão política da Educação Popular é a defesa de uma classe social, que se identifica com os mais empobrecidos numa sociedade marcada historicamente pela exclusão social como a brasileira, pautada na construção democrática de um projeto de nação e de mundo que supere essas desigualdades sociais. (BRASIL, 2014, p. 29)

Assim como a história da degradação ambiental, também a do analfabetismo é antiga e vêm ambas sendo construídas a duras penas, resultantes da mesma lógica exploratória que devasta a vida. Segundo Rodrigues (2011), ainda na sociedade escravocrata do período colonial há a difusão do ensino primário destinado a todos os cidadãos, mas como naquela época somente possuíam cidadania as elites econômicas, então apenas a elas se destinava a educação. Segundo essa autora, decorre da década de 20 o início da luta pela EP, nas décadas 
de 1930 e 1950 houve uma redução significativa dos índices de analfabetos no Brasil passando de 65\% na década de 1920 para 40\% no final da década de 1950, concebendo importância para a alfabetização em função do desenvolvimento da mão de obra necessária àquele estágio de capitalismo industrial emergente no Brasil. Essa luta pela EP se intensifica na década de 1960.

O Marco de Referência da Educação Popular para as Políticas Públicas diz que antes da definição da história da EP é preciso considerar, primeiramente, dois desafios: o conceitual e o político. No aspecto conceitual, em alguns momentos ela é vista como uma educação do povo, pelo direito de todos à educação. Em outros momentos, ela é entendida como uma prática educativa comprometida com uma concepção emancipatória de educação, vinculada a um projeto social de mudança para a construção de uma sociedade igualitária, em um país soberano e formador de cidadania. A EP vista como formadora da consciência nacional e potenciadora de transformações. Há ainda outro sentido atribuído à EP, que é o da "educação para o povo". Esse sentido a insere em uma concepção de educação instrumentadora e voltada para servir ao mercado. Esse era o sentido da alfabetização de adultos feita pelo Mobral durante o período de ditadura militar no país.

A EP emancipadora sempre esteve vinculada às lutas em defesa da escola pública e, enquanto proposta de educação emancipatória, reconhece o valor do espaço escolar para a construção de uma mudança social, mas não se reduz a este. Ela se vincula aos movimentos sociais na disputa por outro projeto de sociedade e constrói a sua história permeada por esse contexto.

Esta concepção de Educação Popular se constituiu historicamente na experiência dos movimentos sociais no Brasil, sobretudo no início do século $\mathrm{XX}$, num contexto de lutas de classe e que tinham, dentro do sistema capitalista, a disputa de um projeto alternativo a esse sistema. Estão vinculados a esta concepção de educação emancipatória e libertária os movimentos anarcos sindicais da década de 1920; as organizações sindicais urbanas e rurais, sob influência do ideário comunista; os movimentos de base e populares liderados pela Igreja Católica no contexto dos anos 1960 e pós-Concílio Vaticano II; setores de igrejas evangélicas protestantes; as organizações estudantis secundaristas e universitárias, intensificando suas lutas nos anos que antecedem o regime militar e durante a resistência a esse regime; os sindicatos e organizações populares que se articularam na defesa da reabertura política no País nos anos 1980; as associações de moradores e de bairros que, junto aos espaços constituídos nos conselhos em várias áreas sociais, têm tentado manter essa luta por outra sociedade, que se espelha nos princípios da Educação Popular; nas últimas décadas, cabe destacar que muitos desses sujeitos coletivos e de luta pela Educação Popular emancipatória constituíram-se institucionalmente, em organizações não 
governamentais, ou permanecem em fóruns e movimentos autônomos. (BRASIL, 2014, p. 29)

Nesse contexto, vale ressaltar que a educação popular, aquela designada irrestritamente e com qualidade a todos os cidadãos, permanece como sendo um desafio, ainda mais acentuado mediante a incorporação da educação como direito de todos, expressa na Constituição Federal de 1988. Isto exige dos municípios brasileiros a necessidade de revisão em suas formas de atendimento aos sujeitos de direitos. O Marco de Referência da Educação Popular para as Políticas Públicas é um documento direcionado aos gestores e que leva a todas as escolas públicas o compromisso com uma educação emancipatória, construída junto com o povo, buscando atender aos seus anseios e necessidades. Na cidade de Goiânia, por exemplo, intencionando comprometer-se com uma educação emancipatória, a Secretaria Municipal de Educação de Goiânia (SME), em parceria com as escolas, no início do ano 2001, elabora uma proposta embasada nos princípios da EP, para toda a demanda da educação de jovens e adultos por ela atendida. No mesmo ano, cria o programa AJA-Expansão, estabelecendo parceria, em 2003, com o Programa Brasil Alfabetizado (PBA), que nasce como uma resposta do município de Goiânia à luta pela superação do desafio do analfabetismo.

A Pesquisa Nacional por Amostra de Domicílios (Pnad), realizada em 2012 pelo Instituto Brasileiro de Geografia e Estatística (IBGE) e divulgada em setembro de 2013, indica que o índice de pessoas de 15 anos de idade ou mais que não sabem ler nem escrever subiu de 8,6\%, em 2011, para 8,7\%, em 2012, em âmbito nacional. Embora pequena, é uma margem expressiva e indicadora, sobretudo, das dificuldades encontradas para a superação desse desafio em nosso país. Até 2015, o Brasil deveria reduzir a 6,7\% de analfabetismo da população com mais de 15 anos para cumprir a meta estabelecida com a Unesco (Organização das Nações Unidas para a Educação, Ciência e Cultura) em 2000, durante a Cúpula Mundial de Educação, em Dacar.

Outra pesquisa realizada pelo mesmo órgão, em 2014, e divulgada em novembro de 2015, indica que o Brasil não conseguiu cumprir a meta estabelecida há 15 anos com a Unesco. O índice de analfabetismo passou de 8,5\%, em 2013, para 8,3\%, em 2014, com distorções entre as regiões: 4,4\% região Sul, 16,6\% região Nordeste, 4,6\% região Sudeste, $6,5 \%$ região Centro-Oeste e $9 \%$ região Norte. O instituto estimou a população brasileira em 203,2 milhões, 1,7 milhão a mais do que em 2013 (alta de 0,9\%). Observa-se uma diferença de $0,2 \%$, diminuição correspondente a aproximadamente 408 mil adultos analfabetos a menos 
no país. Uma redução que se torna ainda mais significativa, ao vir acompanhada do aumento do índice populacional.

O movimento do índice de analfabetismo no Brasil é uma expressão do investimento e do compromisso dos gestores e de toda a sociedade civil envolvidos na implementação das políticas públicas para a alfabetização de jovens e adultos. É com alegria que vejo a diminuição desse índice e compartilho da conquista, especialmente por ver a pesquisa que estou apresentando inserida nesse universo e compromissada com a mudança dessa realidade, mas temos ainda $8,3 \%$ de analfabetismo o que corresponde a 13,2 milhões de pessoas. A diferença apontada é expressiva de que algo está sendo feito, de que existe um movimento em torno dessa situação, mas indicadora de que os esforços não estão sendo suficientes ou adequados para a obtenção de melhores resultados. Afinal, muitos já foram os programas realizados e as verbas públicas investidos no atendimento a essa demanda.

Mediante esse fato, as minhas questões de pesquisa se fortalecem. Estou também cada vez mais convencida de que o contexto atual do país e do planeta nos indica que a Educação Ambiental precisa ser colocada no centro das estratégias pedagógicas, como foco integrador, orientando o movimento de ensino e aprendizagem. A esse respeito, Morin (2008, p. 22) expõe que "Eu estou cada vez mais convencido de que a sociedade antropossocial precisa se articular com a ciência da natureza e que tal articulação requer uma reorganização da própria estrutura do saber". O campo da EA se ocupa dessa articulação e, com a experiência vivida nesta pesquisa, alcança a EP por meio da busca de superação do analfabetismo que, no Brasil, é tão integrada à história do país e das relações sociais da população, que facilmente é despercebida e/ou naturalizada. Diante dessa realidade histórica não podemos ancorar nossas naus, o mar é grande e navegar é preciso.

Várias pesquisas já reconstituíram a história das ações implementadas pelo Governo Brasileiro para a educação de jovens e adultos. Em Goiás, especialmente Machado (1997), Rodrigues (2000), Silva (2004), Gomes (2006), Santos (2007), Costa (2008) transitam por essa história no Brasil e em Goiás, evidenciando um percurso de interesses econômicos e políticos assim como de dependência das grandes potências internacionais. A esse respeito Gomes (2006, p. 54) apresenta que: "Nota-se, [...] que a UNESCO, junto com UNICEF, FMI, BIRD e outros agentes financiadores, muito mais que financiar tem a intenção de interferir nas prioridades e na forma de atendimento educacional”. É difícil não acreditar que existem muitos interesses em jogo. Quando o assunto é financiamento internacional, eles estão assentados nos mesmos princípios de mercado onde a educação, portanto, se transforma em mercadoria. Assim, a UNESCO defende, sobretudo, seus próprios interesses e dos grupos 
financiadores mais que os interesses das comunidades e da especificidade do atendimento educacional a que se propõe.

A década de 1960 foi relevante tanto para a EA quanto para a EP no Brasil. Por ocasião do golpe militar em 1964, estava sendo desenvolvida em todo o país a experiência de alfabetização de adultos preconizada por Paulo Freire. Nessa mesma década são iniciadas as discussões ambientais no mundo e na América Latina. Gutiérrez e Prado (2000, p.13) comentam que "Em quase todos os países da região, a sociedade civil organizada transformou-se numa contrapartida importante para as instituições governamentais em temas como saúde, meio ambiente e direitos humanos, temas estes que permaneceram à margem das políticas públicas."

Essa conjuntura avulta a importância da única proposta que teve como objetivo a formação de cidadãos numa perspectiva transformadora no Brasil, aquela desenvolvida por Paulo Freire. Porque tendo nascida do compromisso de qualificar mão de obra para atender as necessidades do processo de industrialização, a educação voltada para a população jovem e adulta tinha como principal função formar indivíduos sem visão crítica e sem poder de decisão para atender a interesses externos de dominação e sujeição. Por essa razão, a proposta desenvolvida por Paulo Freire foi cassada pelo regime militar, que via nessa práxis educativa uma ameaça à ordem estabelecida.

Ao longo dessa mesma década de 1960 vão se fortalecendo as discussões ambientais no mundo e na América Latina. Começaram com movimentos pontuais de preservação e as preocupações com as águas internacionais. A primeira discussão a tomar o ambiente internacional foi a iniciada por Jaques Cousteau.

As discussões começaram na década de 1960, com movimentos locais de preservação de biomas e das águas internacionais. Era o início da ideia de Bem Comum, um bioma ou meio ambiente de uso coletivo e de consequências igualmente coletivas. A primeira discussão a tomar o ambiente internacional foi a iniciada por Jaques Cousteau e seu apreço pelos oceanos.

Durante a década de 1970, os países desenvolvidos começaram a sentir as consequências do impacto causado pelas indústrias e sua poluição e se atentaram para um novo interesse, indagando-se: como sobreviveriam os seres humanos, se no mundo a vida não fosse mais capaz de se sustentar?

Das discussões em relação à matéria-prima e aos Bens Comunais, ou Bens Comuns, surgiu o movimento pela proteção ao meio ambiente. Embora os impactos do expansionismo industrial no meio ambiente fossem extremamente evidentes, a ganância e a vontade de desenvolver a indústria e 
a economia ainda falavam mais alto para muitos dos países desenvolvidos. (NEVES, 2009, p. 7)

Em 1972, na "Conferência das Nações Unidas sobre o Meio Ambiente Humano" realizada em Estocolmo, foi proposto o chamado "crescimento zero" para resolução da crise de recursos naturais não renováveis. O crescimento natural da população foi colocado como principal causa dos problemas ambientais do planeta, não se questionava o modelo de desenvolvimento como produtor da degradação ambiental e esgotamento dos recursos naturais. Duas décadas depois, a proposta de Desenvolvimento Sustentável foi apresentada no documento "Nosso Futuro Comum" produzido em 1987 pela Comissão Mundial sobre Meio Ambiente e Desenvolvimento e apresentada como base de discussão na Conferência Rio-92. (BRUNDTLAND, 1991)

A proposta de Desenvolvimento Sustentável foi debatida e amadurecida ao longo da década de 1990, a partir da ideia de que todas as crises são uma só e que o desenvolvimento sustentável é aquele "que satisfaz as necessidades presentes, sem comprometer a capacidade das gerações futuras de suprir suas próprias necessidades" segundo definição do supracitado relatório Brundtland (1991). A partir daí, todos os países envolvidos nas discussões ambientais, até mesmo os não envolvidos, deveriam tomar medidas para a proteção ambiental. Caso essas medidas não fossem tomadas, as consequências afetariam todo o planeta e não apenas um único país. Sobre essa compreensão de sustentabilidade, Catalão (2009, p. 252) adverte que:

A ideia de desenvolvimento sustentável mostra seus limites e suas contradições incontornáveis quando visa solucionar os impasses do desenvolvimento sem questionar o modo de produção capitalista. O cerne do projeto capitalista de desenvolvimento é essencialmente unidimensional. $\mathrm{O}$ crescimento ilimitado do mercado e outros indicadores de desenvolvimento aniquilam nos seus fundamentos a possibilidade de pleno desenvolvimento humano com preservação ambiental. (CATALÃO, 1993 apud CATALÃO, 2009, p. 252)

Buscando dialogar com o movimento da sustentabilidade e promover a sustentabilidade nos municípios brasileiros, em 2005 o Ministério do Meio Ambiente (MMA) elaborou o Programa Municípios Educadores Sustentáveis visando

promover o diálogo entre os diversos setores organizados e os projetos e ações de meio ambiente desenvolvidos nos municípios, bacias hidrográficas e regiões administrativas. Ao mesmo tempo, propõe dar-lhes um enfoque educativo, que propicia às cidadãs e aos cidadãos oportunidades, no dia-adia, de serem também educadores / editores de conhecimento 
socioambiental, formando outras pessoas, e multiplicando-se sucessivamente, de modo que o município se transforme em educador para a sustentabilidade. (BRANDÃO, 2005, p. 5)

O livro "Aqui é onde eu moro, aqui nós vivemos", de autoria do professor Carlos Rodrigues Brandão, escrito a convite do MMA para subsidiar esse programa, foi uma ferramenta fundamental para a implementação desse trabalho junto aos municípios. Ao prefaciar esse livro Sorrentino, diretor de Educação Ambiental do MMA, confessa: "Li e me emocionei. O professor Brandão materializava em palavras o seu testemunho de vida". E o autor fala sobre sustentabilidade explicando que

em um primeiro momento opõe-se a tudo o que sugere: desequilíbrio, competição, conflito, ganância, individualismo, domínio, destruição, expropriação e conquistas materiais indevidas e desequilibradas, em termos de mudança e transformação da sociedade ou do ambiente. (BRANDÃO, 2005, p. 86)

Essa noção de sustentabilidade exige mudanças profundas nas relações humanas e sociais. Nesse desafio, a ética é colocada no centro conclamando cada indivíduo, cada comunidade, para novas atitudes consigo, com o outro, com a sociedade e com a natureza onde a educação, via importante para o alcance de qualquer mudança profunda, torna-se o canal para o desaguar das transformações. Apascentando essas águas, a história da EA e da EP revela a abertura desses campos para as mudanças urgentes que estão demandando atenção, escuta e cuidado.

Durante a década de 1970, o Brasil e a América Latina viviam em um contexto de governos autoritários e envolvidos em lutas pela democracia. Essas lutas dão origem ao movimento ecológico que nasce na relação com o movimento contestatório da contracultura e da esquerda. Dessa maneira, observa-se que o contexto histórico que deu origem ao movimento ambiental e, posteriormente, à Educação Ambiental, é o mesmo que originou, portanto, o movimento da Educação Popular.

Podemos dizer que o movimento ecológico no Brasil será resultado do encontro de dois contextos socioculturais: a) o contexto internacional da crítica contracultural e das formas de luta do ecologismo europeu e norteamericano; b) o contexto nacional, em que a recepção do ideário ecológico acontece no âmbito da cultura política e dos movimentos sociais do país, assim como da América Latina. No caso particular do Brasil, por exemplo, não se poderia pensar a questão ambiental sem também levar em conta as formas pelas quais foi sendo marcada por outros movimentos sociais, ao mesmo tempo em que os marcou. Nos anos 80 e 90 houve progressivo diálogo e aproximação, com muita influência, entre as lutas ecológicas e os movimentos sociais urbanos, os movimentos populares de um modo geral, a 
ação política da educação popular, da Igreja da libertação e das Comunidades Eclesiais de Base. (CARVALHO, 2011, p. 50)

A Educação Ambiental nasce do movimento ecológico e está, portanto, conectada ao movimento social. Segundo Carvalho (2011, p. 51), os movimentos ecológicos suscitam a importância de preparar as pessoas para ações sociais ambientalmente adequadas, além de chamar a atenção para o fato de que os recursos naturais são finitos. A humanidade precisa, então, olhar para o meio ambiente onde vive e aprender a se relacionar com ele. Dessa maneira, a Educação Ambiental vai se fortalecendo como proposta educativa e adentra o campo educacional dialogando com suas tradições, teorias e saberes.

A Educação Ambiental é parte do movimento ecológico. Surge da preocupação da sociedade com o futuro da vida e com a qualidade da existência das presentes e futuras gerações. Nesse sentido, podemos dizer que a EA é herdeira direta do debate ecológico e está entre as alternativas que visam construir novas maneiras de os grupos sociais se relacionarem com o meio ambiente. (CARVALHO, 2011, p. 51)

A busca do diálogo entre os campos que se apresentaram na pesquisa me conduz a perceber o valor da contribuição da Educação Ambiental Crítica. Essa vertente se apresenta compromissada com a transformação social, com uma educação integradora e vinculada ao contexto histórico e cultural dos sujeitos, tornando-se, portanto, fonte para o encontro da EA com a EP, ampliando e fortalecendo o encontro dessas águas. Referência desse pensamento, Loureiro (2013, p. 52) nos apresenta seu entendimento acerca da "crítica" em educação. Ele inicia a sua explicação indagando:

Mas, afinal, o que cabe no interior da "crítica" em educação, particularmente
na educação ambiental? Por "teorias críticas" se entendem os modos de
pensar e fazer a educação que refutam as premissas pedagógicas tradicionais
de: organização curricular fragmentada e hierarquizada; neutralidade do
conhecimento transmitido e produzido; e organização escolar e planejamento
do processo de ensino e aprendizagem concebidos como "pura
racionalidade", pautados em finalidades pedagógicas "desinteressadas"
quanto às implicações sociais de suas práticas. Ao contrário, as proposições
críticas admitem que o conhecimento é uma construção social,
historicamente datada, não neutra, que atende a diferentes fins em cada
sociedade, reproduzindo e produzindo relações sociais, inclusive as que se
referem à vinculação entre saber e poder. Isso basicamente significou
incorporar, no interior da "crítica" em teoria educacional, as inúmeras
perspectivas marxistas, a fenomenologia e a hermenêutica", que poderiam e

\footnotetext{
${ }^{6}$ Lembro que produção vem do grego poiésis e significa criação.

${ }^{7}$ Apesar de nem sempre os adeptos destas duas últimas tradições filosóficas se afinarem com a denominação "crítica", inclusive fazendo questionamentos às formulações dos críticos, o que ressalto aqui, seguindo uma
} 
deveriam dialogar mais na construção de uma educação que se consolidasse como distinta das pedagogias tradicionais.

Sob essa perspectiva apresentada, vê-se que as premissas refutadas e as proposições admitidas pela "teoria crítica" são comuns a toda educação que se propõe ser transformadora e capaz de contribuir para a construção de um mundo melhor, por conseguinte, comuns também à EA. Por esse viés, o diálogo entre a EA e a EP se fortalece e se aproxima da realidade investigada, evidenciando que a Educação Ambiental torna-se, portanto, relevante nesse espaço por trazer a possibilidade de fazer a conexão entre a reflexão e a ação, desnaturalizando as relações estabelecidas, apontando caminhos para a melhoria da qualidade de vida dos cooperados, transformando relações. Torna-se relevante, sobretudo, quando temos em Goiânia uma significativa parcela de adultos analfabetos e de analfabetos funcionais em comunidades que vivem do material reciclável, proveniente de coleta seletiva, tendo nesse ambiente a sua relação com o trabalho. Nestas circunstâncias, para além de uma visão simplista e conservacionista, que vê o ser humano apartado das questões ambientais, reafirma-se ser pertinente entender a EA numa perspectiva crítica onde, segundo Carvalho (2011, p. 156)

\begin{abstract}
Nessa definição, a prática educativa é processo que tem como horizonte formar o sujeito humano enquanto ser social e historicamente situado. Segundo tal perspectiva, a educação não se reduz a uma intervenção centrada no indivíduo, tomado como unidade atomizada e solta no mundo. A formação do indivíduo só faz sentido se pensada em relação com o mundo em que ele vive e pelo qual é responsável. Na EA esta tomada de posição de responsabilidade pelo mundo em que vivemos, inclui aí a responsabilidade com os outros e com o ambiente.
\end{abstract}

A relação negligenciada, da maneira como está constituída, do indivíduo consigo, com o outro e com o mundo, pelo qual é responsável, vem gerando crises de toda ordem: política, social e econômica que se transversalizam na crise ambiental, afetando a todos, pois afinal o planeta Terra ainda é a única morada da humanidade. É preciso, portanto, trazer para esta discussão o paradigma da Educação Ambiental que questiona as bases estruturais do sistema de produção, distribuição e consumo que dão origem à deterioração ecológica e à desigualdade social.

classificação comum na educação, é o caráter crítico à educação tradicional adotado por muitos educadores a partir de um determinado momento histórico, tendo por base a dialética marxiana ou a hermenêutica ou a fenomenologia. 


\subsection{Educação Popular e Educação Ambiental: confluência das águas}

As questões que norteiam esta pesquisa conduzem para um percurso que se inicia no universo da Educação Ambiental (EA) e se desdobra no universo da Educação Popular (EP) ainda que na minha experiência pessoal o percurso tenha sido o inverso. A contribuição da EA está assentada em estratégias ecopedagógicas, baseada nos princípios da teoria da complexidade (MORIN, 2008) e da transdisciplinaridade (NICOLESCU, 1999), a partir de uma experiência de formação humana de intenção emancipatória durante o processo de alfabetização de trabalhadores de uma cooperativa de resíduos sólidos. Por se tratar de um processo de alfabetização de adultos, situada em uma realidade tão específica, oriunda do viver das pessoas de uma comunidade predominantemente de catadores, a discussão abarcou o campo da Educação Popular (EP). A experiência abordada está inserida, portanto, no universo de uma educação voltada para a "formação do sujeito aprendiz como um ator crítico, criativo, solidário e participante". (BRANDÃO, 2008, p. 35)

A junção desses campos conduz para uma ideia de acoplamento (MATURANA, 2001, p. 87) da Educação Ambiental (EA) com a Educação Popular (EP). Uma noção de EA que tem como objetivo formar cidadãos com consciência local e planetária, capaz de mobilizar a solidariedade dos humanos para com todas as formas de vida. (CATALÃO, 2009, p. 259) Uma noção de EP que toma os sujeitos das classes populares como protagonistas emergentes de um processo, Brandão (2008, p. 24) que se inicia na perspectiva da EP preconizada por Paulo Freire (1987), portanto, com uma história e uma intencionalidade nascidas na realidade dos próprios sujeitos que as vivem e as fazem.

A compreensão é de que tanto a EA quanto a EP são territórios considerados como unidades autopoiéticas, com estruturas particulares, mas abertas a interações capazes de constituir "perturbações recíprocas". No encontro, essas duas estruturas se alteram mutuamente e se transformam, ocasionando a ideia de acoplamento. Ao abstrair a presença da EA e da EP na experiência de alfabetização de catadores, fui me dando conta de que vai uma alimentando e modificando a outra reciprocamente.

A principal intenção neste capítulo é apresentar os elos entre esses dois campos localizando de que maneira, de fato, a junção da Educação Popular com a Educação Ambiental pode contribuir com o universo das discussões de uma educação que pretende ser libertadora da condição de mera sobrevivência humana. A experiência vivida por esta pesquisa me permitiu observar que esses campos se constituíram como complementares e componentes de um só mundo. A experiência corroborou com o entendimento de que tanto 
um quanto o outro se assenta no compromisso dos que sonham com um mundo bonito, justo e amoroso. Dos que trazem na alma a angústia provocada pelas injustiças, pelas discriminações, pelas exclusões, pela forma compartimentada e fragmentadora como o homem vem se relacionando consigo mesmo, com os outros, com a natureza e, portanto, com a vida. $\mathrm{O}$ universo dos que sentem fome e têm roubados seus sonhos. Dos que sentem sede e têm roubado o seu céu.

A Educação Ambiental foi a responsável pela sobrevivência da espécie humana no planeta. Ela é resultado da interação do homem com a natureza, da sua necessidade de se proteger e sobreviver às ameaças da natureza. Pensando assim, a prática da Educação Ambiental existe desde que o homem começou a interagir com o seu meio, intervindo, defendendo-se e transmitindo seus conhecimentos às novas gerações.

Este conhecimento foi passando de geração em geração, muitas vezes acrescido de novas descobertas. E mais: segundo Donella, "a natureza mostrou-se também fonte de alegria, (...) de inspiração para a música, arte e religião, significando enfim valores internos e perenes..." Para a pesquisadora, "desde o primeiro momento em que os seres humanos começaram a interagir com o mundo ao seu redor, e ensinaram seus filhos a fazerem o mesmo, estava havendo educação e educação ambiental". (CZAPSKI, 1998, p. 21)

No entanto, é nova a nascente da Educação Ambiental integrada a técnicas formativas e a procedimentos didáticos pedagógicos intencionados à educação formal e ao reaprendizado da humanidade a se relacionar com o meio ambiente em que vive. Uma nascente nova, mas de águas abundantes em seu percurso. O contexto ambiental do planeta nas décadas de 1950 e 1960 apresenta sinais incisivos de ameaça à vida: chuva ácida, envenenamento por uso indiscriminado de DDT, acidente com navio petroleiro poluindo o mar e matando milhares de vidas aquáticas, muitas espécies animais em extinção, bomba atômica, guerras, dentre outros episódios. Assustada com os resultados das suas criações, a humanidade inicia movimentos ambientais para pensar alternativas de sustentação da vida no planeta e, nesse contexto de aflição, a educação se abre como um caminho próspero de reaprendizagens para que a vida seja preservada.

Sobre o surgimento da Educação Ambiental, Gaudiano (2005, p. 53) apresenta que

A educação ambiental é um campo emergente da pedagogia, cuja patente internacional não recua para além do decênio de 1970 e, na maior parte dos países da América latina e das Caraíbas, da década de 1980. Trata-se também de um campo que se encontra em processo de constituição inicial, que ainda não consegue chegar apropriadamente às estruturas e práticas das 
instituições educativas oficiais na região latino-americana, embora nos países industrializados se afirme estar plenamente incorporado.

O mais importante em relação ao nascimento da Educação Ambiental não se insere somente em sua aparição temporal, é relevante também o seu fortalecimento na relação com os outros campos e nos discursos implicados. Nesse sentido, durante o VI Congresso de Investigação Educativa (2002) ocorrido no México, a Educação Ambiental fez parte de um painel de discussão chamado "<<As irmãs incómodas $>>$ para fazer referência à posição mantida pela educação ambiental em relação a outros campos, como da educação e género, educação bilíngue multicultural e educação de adultos". (GAUDIANO, 2005, p. 53-54). Observa-se com isto que a EA e a EP compartilham de lutas semelhantes também nesse espaço da efetivação do campo de conhecimento, pois a origem das ações desses campos em defesa da vida está nas lutas sociais.

Essas analogias colocam esses campos do mesmo lado quando as disputas suscitam uma relação de poder, gerando divergências e lutas decorrentes de diferentes interesses entre os campos, uma relação entre opressores e oprimidos, a mesma que existe no ambiente social que os originam. A que Freire (1987) atribui aos oprimidos a capacidade de restaurar a humanidade. É uma disputa que perpassa sobre qual projeto e visão de mundo pode melhor atender as necessidades do presente e as perspectivas do futuro. Uma discussão imprescindível tanto para o fortalecimento da EA quanto da EP e que seu desdobramento vai afetar a problematização do trabalho com a alfabetização de adultos, nessas cooperativas de resíduos sólidos.

A Educação Ambiental, como componente de uma cidadania abrangente, está relacionada com uma nova forma da relação homem/natureza. Assim, também a EA se constitui como um ato político voltado para a transformação social e representa um instrumento essencial para superar os atuais impasses da nossa sociedade. Essa mesma intencionalidade que orienta a EA como parte essencial da formação cidadã e humana dialoga com uma Educação Popular pensada como um instrumento de emancipação dos oprimidos, posto que a opressão da natureza tem se manifestado historicamente como outra face da opressão humana.

E esta luta somente tem sentido quando os oprimidos, ao buscarem recuperar sua humanidade, que é uma forma de criá-la, não se sentem idealistamente opressores, nem se tornam, de fato, opressores dos opressores, mas restauradores da humanidade em ambos. E aí está a grande tarefa humanista e histórica dos oprimidos - libertar-se a si e aos opressores. (FREIRE, 1987, p. 30) 
Essas relações desafiadoras de opressão se materializam quando vemos que a maior parte dos sujeitos da EP, especialmente os adultos alfabetizandos, possui histórias semelhantes, ou seja: histórias de exclusão, de falta de trabalho, de exploração, de serem corresponsáveis pela sobrevivência familiar e obrigados a inventar um modo de (sobre) viver. Ao observarmos estas condições, entendemos, inclusive, a razão da grande demanda de adultos analfabetos em cooperativas de catadores de materiais recicláveis.

Para essas pessoas, voltar para a escola ou iniciar uma formação escolar constitui-se em um enorme desafio, pois elas encontram dificuldades em se adaptar à cultura escolar de uma escola feita "para elas" e não "com elas". Dificuldade em cumprir uma rotina de ir todos os dias para a escola após o cansaço do trabalho e o enfrentamento das adversidades presentes em suas vidas. Dificuldade, especialmente, por já terem esquecido os seus sonhos e entenderem que já não podem mais sonhar. Por conta desse e de outros fatores vinculados à escola e a outras situações mais próximas, a evasão e a baixa frequência são desafios que se configuram também para a trajetória da turma de alfabetizandos desta pesquisa.

A experiência desta pesquisa foi vivida ao longo de 8 meses junto a uma comunidade de catadores trabalhadores de uma cooperativa de resíduos sólidos na cidade de Goiânia. Ela se deu por meio da convivência com o grupo que compunha a turma constituída como campo de pesquisa e deixou claro que o modelo de escola tradicional, formal, instrucional e estranha ao seu viver, oferecido institucionalmente e indistintamente, não o contempla. A escola para essas pessoas precisa ser um espaço de convivência, como um prolongamento da vida, que seja feita por elas, para uma troca a partir do que a vida lhes exige, ensina e cobra a cada dia, a partir da sede que lhes conduz à busca de outras águas.

Com esse entendimento, lanço-me nessa travessia buscando colocar em prática os princípios da EP e da EA ao trazê-las para o contexto dessa turma, que tem sua ação focada em estratégias da Educação Ambiental. O que minimamente se pode revelar é que essa turma está inserida no universo agregador da educação que acolhe a EP e a EA unidas por uma experiência que recontextualiza tanto uma quanto a outra. Uma experiência que, sobretudo, é originada a partir das necessidades e do contexto da vida dos que a vivem. Sem compromisso, portanto, com formações específicas para o mercado de trabalho, associadas a práticas voltadas ao atendimento das lógicas do mercado do grande capital. O contexto dessa comunidade é o lugar, por conseguinte, de onde brotam as dimensões cultural, social, política, espiritual, religiosa que vão direcionar o olhar ao longo do percurso.

A confluência das águas que conduzem a EA e a EP se faz por meio do percurso histórico de onde surgiram e dos compromissos de ambas com a construção de uma sociedade 
justa, igualitária, humana e sustentada em outros valores, diferentes dos considerados pelo consumo, pelo mercado, onde o ter se sobrepõe à satisfação da existência do ser. Os princípios oriundos dos compromissos da EA e da EP indicam os pontos de convergência entre ambas ao mesmo tempo em que deixam transparecer entendimentos distintos no movimento que dá contorno às margens dessas águas.

Uma luz penetra as sombras das águas agitadas que envolvem o diálogo entre a EA e a EP e revela que esse diálogo perpassa pela abordagem entre a tradição marxista, de grande influência sobre a EP, e a teoria da complexidade moriniana, que alcança a abrangência da EA. Essa é uma abordagem envolvida no diálogo proposto, que adentra em um mar de águas profundas e agitadas, que no contexto atual da vida no planeta precisam ser apascentadas pelas águas serenas do entendimento, do diálogo e da amorosidade, para o sustento da vida. Por meio da experiência realizada na alfabetização de catadores, com estratégias da EA, o diálogo entre a EA e a EP superou as divergências que o antecediam. Em seus estudos, Loureiro (2007, p.13) observou que

as premissas básicas de ambas são, no geral, similares em certos termos filosóficos e ontológicos, distanciando-se em termos de compreensão de processos históricos e de formação social, resultando em diferenciadas implicações políticas e educacionais.

Sabendo que o mar existe, os princípios e diretrizes da EA e da EP demonstram o que esses campos trazem de agregador entre eles. Dessa maneira, o diálogo se fortalece para a superação das divergências e a harmonia do encontro da EA com a EP.

\footnotetext{
Princípios da Educação Popular

I - Emancipação e poder popular.

II - Participação popular nos espaços públicos.

III - Equidade nas políticas públicas fundamentada na solidariedade, na amorosidade.

IV - Conhecimento crítico e transformação da realidade.

V - Avaliação e sistematização de saberes e práticas.

VI - Justiça política, econômica e socioambiental. (BRASÍLIA, 2014, p. 49)
}

Por meio destes princípios da EP apresentados pelo Marco de Referência da Educação Popular para as Políticas Públicas percebemos a amplitude social do alcance de seus propósitos, onde a educação está integrada à sociedade e, especialmente, aos movimentos sociais populares. A referência ao aspecto ambiental é feita, especificamente, no item VI onde 
a percepção ambiental aparece como um desdobramento do social, apontada como um direito inserido na justiça social. Essa é a visão emancipatória da EA que "agrega ao conceito de cidadania o direito à qualidade ambiental da vida para todos os cidadãos". (CATALÃO, 2009, p. 257). Esses princípios da EP se fundem aos da EA, na dimensão ampliada da educação nos espaços informais da sociedade, nas trocas de saberes.

A visão emancipatória é a que surge diante dos fatos ambientais que intimidam a vida no planeta. Diante das ameaças, as populações se organizam em defesa de seus direitos ambientais. A água é um grande exemplo de movimentos agregadores de lutas sociais, a que chega e a que sai de nossas casas, a que irriga nossos campos e permeia nossas cidades. Uma visão, portanto, da maior relevância por direcionar-se para uma atuação social organizada na defesa de seus direitos e interesses. Ao mesmo tempo, é preciso considerar outros aspectos da subjetividade humana e do pertencimento, que mobilizam as pessoas para as lutas sociais e ambientais em defesa da vida, sob o risco de reduzir-se a uma visão utilitarista. Dessa forma, as relações com o meio ambiente estão sempre voltadas para o exterior, distantes e dissociadas do ser, portanto, das mudanças de valores para a responsabilização pessoal e cuidados que nascem da interação subjetiva consigo, com a sociedade e com a natureza.

A Educação Ambiental insere-se nessa dupla pilotagem da educação. Ora volta-se ao exterior para compreendê-lo e transformá-lo criticamente, ora propõe um diálogo interior para emergência de valores enraizados no sentido do pertencimento e responsabilidade pessoal. (CATALÃO, 2009, p. 257)

Esse item VI remete também a outras análises, dentre elas, a de que essa visão emancipatória compreende apenas uma parte da atuação da EA, não abarca o alcance amplo, do micro ao macrocosmo, abrangente e transformador da EA. Vemos na fala da Maria P, na epígrafe deste capítulo, quando ela diz: "fez mudar dentro de mim", que a EA tem um potencial transformador que se inicia na ecologia interna do próprio sujeito, navegando para as águas da ecologia humana. Dansa, Pato e Corrêa (2014, p. 208-209) corroboram com esse entendimento explicando que

É a partir desse nível molecular que se inicia o processo de educação ambiental e ecologia humana. É na interface entre ecologia da mente, do desejo, do corpo, da linguagem, do esquecimento, da representação e da contradição, naquele campo onde cada homem é particular e geral, onde corpo e mente se tornam, muitas vezes, inimigos dissonantes, onde o coletivo é fruto das inúmeras tomadas de decisões de todos retroagindo sobre o todo, é ali que nós nos colocamos como observadores participantes desse movimento para compreender e construir uma forma de diálogo de cada um consigo mesmo, com os outros internalizados nas suas mais variadas 
nuances, com o seu contexto de relações compreendido como um processo de ação - interpretação - ação.

A Educação Ambiental agrega, portanto, diversas visões que ampliam o alcance das suas ações atuações, numa relação intrínseca entre reflexão e ação. (CATALÃO, 2009, p. 260 - 266) destaca "aquelas que experimentam e refletem o caráter dialógico e holístico da Educação Ambiental”. Dentre elas a ecopedagogia, a educação para o desenvolvimento sustentável, a transversalidade, a ecologia humana e o método vivencial, a corporeidade, a alfabetização ecológica e a educação integral.

A experiência vivida no campo desta pesquisa agregou as diversas visões da EA por meio das estratégias utilizadas. A ecopedagogia se fez presente ao integrar os educandos em uma relação direta com a biodiversidade da vida, com os elementos que constituem os reinos da natureza e com a percepção do planeta Terra como nossa casa. A educação para o desenvolvimento sustentável foi envolvida na experiência pelo que ela ocasiona de relacionamento solidário entre os seres humanos e entre os outros seres do planeta. A transversalidade foi a ponte construída entre a vida cotidiana dos educandos envolvidos e os conhecimentos adquiridos, transformando as ações na relação com o meio ambiente. A ecologia humana e o método vivencial estiveram no alicerce dos trabalhos por meio da percepção holística e integradora de tudo o que constitui o mundo. Essa percepção foi exercitada com oficinas, jogos, rodas de conversas e momentos introspectivos que desenvolveram a sensibilização, a criatividade, o sentimento intuitivo e imaginário, a fim de modificar a maneira de ser e estar no mundo.

Além dessas visões, também a corporeidade, a alfabetização ecológica e a educação integral estiveram constituindo a experiência da pesquisa. A corporeidade implica na relação do corpo com a compreensão da vida. E na experiência realizada, a respiração profunda, exercícios de percepção corporal, alongamentos, de forma criteriosa e frequente faziam parte das atuações como estratégias para integração da ação e do pensamento, no caminho para a religação das fragmentações. A alfabetização ecológica se deu por meio da conexão entre a natureza e os resíduos sólidos que chegam à cooperativa. A percepção do encadeamento de ações e transformações da extração da matéria prima, à triagem do resíduo para o retorno ao ciclo. Uma rede de relações que chega ao trabalho na turma promovendo o sentido da cooperação, interação e compreensão da organização ecológica na promoção da aprendizagem.

A experiência agregadora das diversas visões da EA vivida na turma de alfabetização de catadores demonstra o percurso integrador e complexo por onde a EA navega. Para 
responder as questões da pesquisa, era preciso por em prática os princípios da EA e esses princípios não se restringem ao social. A experiência se abriu então para aventuras em busca do desenvolvimento e da ampliação de novas interações entre a EA e a EP, mas, notadamente, em busca de novas interações com a vida. Morin (2011, p. 109) alerta para o perigo reducionista dizendo que

\begin{abstract}
Assim, o perigo interno que corrói o pensamento ecológico é o ecorreducionismo. O pensamento que reduz todos os problemas apenas ao problema da sociedade. Na própria concepção ecológica, diversas reduções produzem automutilação. Assim, a redução da ideia de ecossistema à ideia de equilíbrio, escamoteia a dimensão evolutiva. A partir daí, uma ecopolítica, que obedece à mesma simplificação, tende a considerar como norma a adaptação ao equilíbrio, portanto um imobilismo de "crescimento zero". Ora, assim como o equilíbrio é o grau zero da ecopolítica, o crescimento zero é o grau zero da ciência ecológica. O ecologismo que não concebe a possibilidade de novos desenvolvimentos na aventura da vida e na aventura humana (quer dizer, que não concebe a vida e a humanidade também como aventuras) torna-se tão mutilador como aquilo que combate.
\end{abstract}

Assim como "todo artista tem que ir aonde o povo está", Nascimento (1998) feito artistas, também a EA e a EP existem em função do povo, ou seja, são uma criação humana e ao povo se voltam para atender suas reivindicações e lutas. Nesse sentido, ambas possuem uma origem comum, mas nem sempre caminharam juntas e encontrar a bifurcação desses caminhos está sendo uma busca necessária para explicar se houve, de fato, a junção desses campos na experiência realizada. Com o intuito de encontrar os elos submersos, tenho navegado pelas águas das concepções, referências teóricas, da história e dos documentos de cada um desses campos. Assim, tenho percebido que os princípios e diretrizes desses campos são uma síntese e uma expressão dos compromissos e dos movimentos que os originaram, mas para compreendê-los é preciso saber como, onde e quando se originam. Com essa intenção, apresento um pouco dos percursos navegados por cada campo para, posteriormente, destacar alguns princípios e diretrizes que contribuem para a revelação desses elos.

A Educação Ambiental tem sua origem nos movimentos ambientais ao longo do século XX. Esses movimentos nem sempre se originaram em lutas populares porque, em seu início, eram os brados solitários de alguns, como o Comandante Jacques Cousteau e a bióloga Rachel Carson, dentre outros, que originavam os movimentos. Muitos movimentos apontavam para riscos ambientais iminentes que, de maneira geral, ressoavam como algo distante, fora da realidade, e não como uma ameaça real, pois não eram sentidos como uma intimidação à vida. Mas o destino dos brados é o eco no movimento social, então, esses brados ecoaram provocando movimentos de grande repercussão. Cousteau e Carson 
alertaram, respectivamente, sobre a ameaça aos corais e à vida marinha e ao uso indiscriminado do DDT nas plantações contaminando o solo irreversivelmente. Ameaças silenciosas e invisíveis, mas de grande impacto sobre a sustentação da vida no planeta.

O início dos movimentos ambientais se confronta com o peso da concepção de infinitude dos recursos naturais muito presente naquela época, e de certa forma ainda hoje presente e arraigada. Esse foi um juízo muito enraizado ao longo da história da humanidade, devido à maneira como construiu sua relação com a natureza. E uma raiz tão profunda sempre deixa sua seiva no chão onde fez brotar a árvore. O próprio movimento comunista, fonte da EP, por algum momento considerou o movimento ambiental como alienação. Um olhar que até hoje se faz presente no entendimento dos mais conservadores. Desfazer esses mitos é mais uma tarefa da interface da EA com a EP que se interpõe no ambiente da sustentação da vida. Portanto, no amálgama desses campos, as águas do movimento social de onde brota a EP fortalecem o compromisso popular da EA, enquanto as águas do meio ambiente de onde brotam a EA fortalecem o compromisso da EP com uma educação holística, restauradora das conexões e religadora do saber, ampliando o campo de atuação da EP. O Fórum Global foi um marco do acoplamento da EA aos movimentos sociais populares. A esse respeito Carvalho (2011, p. 53-54) conta que

Na sociedade brasileira, o evento não governamental da última década mais significativo para o avanço da EA foi o Fórum Global, que ocorreu paralelamente à Conferência da ONU sobre Desenvolvimento e Meio Ambiente, no Rio de Janeiro, em 1992, conhecida como Rio 92. Nessa ocasião, as ONGs e os movimentos sociais de todo o mundo reunidos no Fórum Global formularam o Tratado de Educação Ambiental para as Sociedades Sustentáveis, cuja importância foi definir o marco político para o projeto pedagógico da EA. Esse tratado está na base da formação da Rede Brasileira de Educação Ambiental, bem como das diversas redes estaduais, que formam grande articulação de entidades não governamentais, escolas, universidades e pessoas que querem fortalecer as diferentes ações, atividades, programas e políticas em EA.

Como vemos, as diretrizes da EA no Brasil têm sua origem e vínculos em movimentos que se iniciaram para lá das 200 milhas marítimas. O documento: A Implantação da Educação Ambiental no Brasil, Czapski (1998) adotado aqui como referência neste percurso, traz das águas de além-mar até o contexto brasileiro alguns episódios ambientais impactantes que desencadearam movimentos alertando sobre a necessidade de medidas de contenção da exploração desenfreada da natureza. Em 1948, ao mesmo tempo em que nasce a ONU e a Declaração Universal dos Direitos Humanos, a disputa de força entre as grandes nações estava sendo feita com a produção desenfreada de armamentos nucleares. Em 1952, ocorreu o 
fenômeno "smog", grande poluição atmosférica resultante da combinação da fumaça das indústrias com a névoa fria e úmida, que matou milhares de pessoas em Londres. Foram episódios impactantes, que marcaram a história ambientalista de onde se origina a Educação Ambiental.

Os anos 60 foram de grande mobilização em todo o planeta: movimento hippie, contracultura, paz e amor, existencialismo, comunismo, manifestações feministas e em favor dos negros e, no bojo das manifestações, também as ambientais. Com relação à educação, surgiram críticas à educação tecnicista e voltada para a formação eficiente para o trabalho. Busca por nova maneira de pensar, agir e sentir. Ao longo dessa década a EA foi sendo gerada e ganhando forma, definindo-se a cada situação, em ininterrupta transformação.

O auge dessa década foi o ano 1968, e o "Clube de Roma" foi um movimento que deixou uma pegada marcante, nascido nesse ano quando, por iniciativa de um empresário italiano, este reuniu em Roma 30 pessoas de vários países, pertencentes a diversos segmentos e áreas sociais, para discutirem sobre as ameaças ambientais. Esse grupo lançou vários documentos, dentre os quais se destacou um relatório denominado "Os limites do Crescimento", lançado em 1972. Esse documento foi relevante por ser um dos primeiros alertas à humanidade sobre a questão ambiental global e, especialmente, pelo impacto que causou ao falar sobre os riscos da exploração gananciosa. Esse documento já traz premissas para o surgimento da EA.

Sob o impacto desse relatório do Clube de Roma, ocorre a Conferência das Nações Unidas sobre o Meio Ambiente Humano, de 5 a 16 de junho de 1972, em Estocolmo, na Suécia, conhecida como a Conferência de Estocolmo. Nela foi criado um organismo novo da ONU voltado somente para a área ambiental, o Programa das Nações Unidas para o Meio Ambiente (PNUMA), com sede em Nairobi, capital do Quênia. A relevância dessa Conferência fez do dia 5 de junho o Dia Mundial do Meio Ambiente. Os 113 países participantes assinaram a "Declaração da ONU sobre o Ambiente Humano". Nesse documento se percebe a EA eclodindo do chão fértil dos compromissos sociais com condutas responsáveis dos indivíduos, das empresas e comunidades. No artigo 19 ele diz:

É indispensável um trabalho de educação em questões ambientais, visando tanto as gerações jovens, como os adultos, dispensando a devida atenção aos setores menos privilegiados, para assentar as bases de uma opinião pública bem informada e de uma conduta responsável dos indivíduos, das empresas e das comunidades, inspirada no sentido de sua responsabilidade, relativamente à proteção e melhoramento do meio ambiente em toda a sua dimensão humana. (DIAS, 2003, p. 372) 
Em 1975, atendendo às recomendações da Conferência de Estocolmo, a Unesco promove em Belgrado, Iugoslávia, um encontro internacional de Educação Ambiental com especialistas de 65 países. Esse encontro gera a Carta de Belgrado, um documento histórico para o movimento ambientalista que traz orientações para um programa internacional de EA. Segundo essas orientações, a EA deve ser contínua, multidisciplinar, integrada às diferenças regionais e voltada para os interesses nacionais. A EA vai iniciando a sua definição.

Entre 14 e 26 de outubro de 1977, dando continuidade às discussões em andamento desde a Conferência de Estocolmo, 1972, perpassando pelo encontro de Belgrado, 1975, ocorre a I Conferência Intergovernamental de Educação Ambiental de Tbilisi, acontecida nesse município, na Geórgia (ex-União Soviética). Foi um encontro de águas fecundas que fertilizaram os campos da EA. Dessa Conferência saíram as definições, os objetivos, os princípios e as estratégias para a Educação Ambiental até hoje adotadas em todo o mundo.

Tbilisi foi um prolongamento de Estocolmo, 1972, que foi de onde surgiu a $1^{a}$ fase do Programa Internacional de Educação Ambiental (PIEA). O PIEA foi sugerido em Estocolmo, mas iniciado em 1975, a partir da reunião de Belgrado, que fortaleceu o surgimento da EA, propondo que esta deveria ser contínua, multidisciplinar, integrada às diferenças regionais e voltada para interesses nacionais. O PIEA organizou reuniões regionais entre 1975 e 1977 na África, nos Estados Árabes, na Europa e na América Latina promovendo estudos sobre a EA.

O Brasil não participou da reunião de Belgrado, nem da reunião de Tbilisi, o argumento foi de que não possuía relações diplomáticas com o bloco soviético. Em decorrência, vários anos se passaram até que os brasileiros tivessem acesso às informações de Tbilisi. Somente a partir de 1997, 20 anos após, as 41 recomendações dessa Conferência foram divulgadas oficialmente no Brasil, de dois modos: na internet, na home Page do Ministério do Meio Ambiente, dos Recursos hídricos e da Amazônia Legal, e por meio de um livro intitulado "Educação Ambiental, as Grandes Orientações da Conferência Internacional de Tbilisi”, publicado pelo IBAMA (1997) .

Durante os anos 70, enquanto no mundo todo crescia a mobilização em função da necessidade de proteção ao meio ambiente, no Brasil o regime militar dava sustentação ao crescimento econômico a qualquer custo, sem nenhuma preocupação ambiental. Era o “Milagre Econômico". Na contramão dessas posturas, em 1972 o Brasil enviou uma delegação oficial a Estocolmo, para a Conferência da ONU sobre o Meio Ambiente Humano e assinou, sem restrições, a Declaração da ONU sobre o Meio Ambiente Humano. No ano seguinte, a Presidência da República criou a Secretaria Especial do Meio Ambiente (SEMA), o primeiro órgão nacional do meio ambiente, que entre as atribuições constava o controle da 
poluição e a educação ambiental. As ações contraditórias do Brasil expressavam muito mais encenações de interesses políticos que legítimos compromissos ambientais.

O relatório Brundtland foi lançado em 1987 com o nome "Nosso Futuro Comum". Esse relatório é fruto de um importante movimento, onde um grupo de 22 pessoas notáveis de diferentes países viajou pelos 5 continentes, ouvindo milhares de pessoas de diferentes segmentos e classes sociais. O objetivo era entregar à ONU um diagnóstico da situação ambiental do mundo, propondo estratégias para superar o problema. Esse relatório propôs o "desenvolvimento sustentável" como caminho para a superação dos desafios ambientais, ao constatar que "a miséria também gera a degradação ambiental e portanto deve ser combatida". Esse documento teve um forte impacto no mundo todo e a partir dele foi definida a realização da Conferência das Nações Unidas para o Meio Ambiente e Desenvolvimento, Rio-92, que se realizou no Rio de Janeiro em 1992.

No Brasil, a década de 1980, antecessora da Conferência das Nações Unidas para o Meio Ambiente e Desenvolvimento, a Rio-92, foi de muita movimentação na criação de órgãos oficiais e na concepção de diretrizes voltadas para a EA. Essa movimentação se intensificou a ponto de fazer com que o Brasil fosse escolhido para sediar essa Conferência. Em 1981 é sancionada a Lei 6.938 que institui a Política Nacional de Meio Ambiente onde, de acordo com Catalão (1993, p. 112), a “Educação Ambiental é apresentada então como princípio, que deverá ser incorporado em todos os níveis de ensino e na educação não formal voltada para as comunidades, objetivando capacitá-las para a participação ativa na defesa do meio ambiente".

Em outubro de 1985 a Comissão Brundtland visita o Brasil, organizando audiências públicas. Em 05 de outubro de 1988 é promulgada a nova Constituição da República Federativa do Brasil que traz um capítulo e vários artigos sobre meio ambiente. Com essa Constituição, o Brasil é considerado vanguardista no movimento ambiental, sendo um dos poucos países que trazem esse compromisso em sua constituição. Nesse mesmo ano, em 22 de dezembro, o ambientalista Chico Mendes é assinado em Xapuri, Acre. Esse episódio tem grande repercussão internacional e tornam-se intensas as pressões internacionais sobre a política ambiental brasileira.

Em resposta a essas pressões, muitas ações se desencadeiam no Brasil. Em fevereiro de 1989 é criado o Ibama, como órgão oficial para coordenar e executar a política nacional do meio ambiente. Nesse mesmo ano é realizado em Recife o I Encontro Nacional sobre Educação Ambiental. Em 20 de agosto de 1991 é lançado no Palácio do Planalto o Projeto de Informações sobre Educação Ambiental, Ibama/MEC. São orientações básicas sobre EA, lançado em encarte da revista Nova Escola. Foi a primeira manifestação formal brasileira a 
partir das recomendações de Tbilisi. A portaria 2124, de 21/11/1991, do MEC, institui em caráter permanente um Grupo de Trabalho para a EA. De 25 a 29 de novembro de 1991, é realizado em Brasília o Encontro Nacional de Políticas e Metodologias para EA. Toda essa movimentação ambiental interna determinou a escolha do Brasil para sediar a Conferência das Nações Unidas para o Meio Ambiente e Desenvolvimento, a Rio-92, e, como desdobramento no país, da Rio - 92, em 1993 foi criado o Ministério do Meio Ambiente (MMA), como uma expressão do compromisso brasileiro, ampliando o espaço de discussão e ação em defesa do meio ambiente.

A Conferência das Nações Unidas para o Meio Ambiente e Desenvolvimento, a Rio92, desencadeou muitas ações em todo o planeta. A partir da "Agenda - 21", um programa de ação com mais de 800 páginas, resultante dessa Conferência, foram reafirmadas as recomendações de Tbilisi. (DIAS, 2003, p. 194-195) O Tratado de Educação Ambiental para Sociedades Sustentáveis e Responsabilidade Global, elaborado pela sociedade civil de todo o planeta presente no Fórum Global, realizado durante a Conferência, foi também um documento estruturado durante a Rio - 92 a partir das orientações de Tbilisi. Essas orientações foram fontes de referência para a criação da Política Nacional de Educação Ambiental, Lei no 9.795/99. "O Brasil é o único país da América Latina que tem uma política nacional específica para a Educação Ambiental.” (DIAS, 2003, p. 201)

O Tratado de Educação Ambiental para Sociedades Sustentáveis e Responsabilidade Global torna-se um documento da maior importância para definição e ação da Educação Ambiental. Ele apresenta o fundamento e os princípios da Educação Ambiental para as sociedades sustentáveis e não deixa dúvida quanto às conexões da EA com os movimentos sociais e com os mais desfavorecidos na cadeia das relações sociais injustas estabelecidas. A introdução desse documento é uma síntese dos vínculos e das intenções:

\section{I - Introdução}

Consideramos que a Educação Ambiental para uma sustentabilidade equitativa é um processo de aprendizagem permanente, baseado no respeito a todas as formas de vida. Tal educação afirma valores e ações que contribuem para a transformação humana e social e para a preservação ecológica. Ela estimula a formação de sociedades socialmente justas e ecologicamente equilibradas, que conservam entre si relação de interdependência e diversidade. Isto requer responsabilidade individual e coletiva a nível local, nacional e planetário. Consideramos que a preparação para as mudanças necessárias depende da compreensão coletiva da natureza sistêmica das crises que ameaçam o futuro do planeta. As causas primárias de problemas como o aumento da pobreza, da degradação humana e ambiental e da violência podem ser identificadas no modelo de civilização 
dominante, que se baseia em superprodução e superconsumo para uns e subconsumo e falta de condições para produzir por parte da grande maioria. Consideramos que são inerentes à crise a erosão dos valores básicos e a alienação e a não-participação da quase totalidade dos indivíduos na construção de seu futuro. É fundamental que as comunidades planejem e implementem suas próprias alternativas às políticas vigentes. Dentre estas alternativas está a necessidade de abolição dos programas de desenvolvimento, ajustes e reformas econômicas que mantêm o atual modelo de crescimento com seus terríveis efeitos sobre o ambiente e a diversidade de espécies, incluindo a humana. Consideramos que a Educação Ambiental deve gerar com urgência mudanças na qualidade de vida e maior consciência de conduta pessoal, assim como harmonia entre os seres humanos e destes com outras formas de vida. (TRATADO, 1992, p. 1)

Ao mesmo tempo em que a EA traça o seu percurso, também a EP delineia o seu caminho. O professor Carlos Rodrigues Brandão, em palestra de abertura do II Seminário Nacional de Formação de Educadores de Jovens e Adultos, realizado em 2007, na Faculdade de Educação da Universidade Federal de Goiás, na cidade de Goiânia, com uma fala brotando da alma de quem, sobretudo, viveu e vive o que está falando, inicia pedindo tolerância aos que desenvolvem novas práticas, porque ele vem de "“um outro tempo", do tempo de Paulo Freire, do tempo em que nasciam as ideias e as práticas de uma "cultura popular" - que mais tarde foi denominada educação popular.” Brandão (2008, p. 17), falando com a naturalidade de quem narra sua própria história, explica:

A cultura popular foi pensada e afirmada como um fator de ação política entre os anos 1960 e 1970, dando lugar a um novo e diferenciado vínculo de compromissos políticos com os movimentos populares. Apenas entre os educadores de vocação mais definitivamente partidária, a questão da educação popular continua sendo uma espécie de educação do, para e através do partido revolucionário. Na maioria dos outros casos, essa educação varia conforme a tendência dos movimentos e de alguma modalidade de presença e de ação popular. Dessa forma, há uma clara diferenciação dirigida a recobrir outras áreas e outros campos de práticas sociais com uma antiga ou mesmo recente vocação equivalentemente popular. Nesse momento, as expressões comuns eram "trabalho com educação popular na área da saúde"; com a "pastoral popular"; com o "trabalho de comunidades populares"; até mesmo com a "escolarização popular". etnia, de cultura, de luta pelos direitos humanos, de ação comunitária e de vocação ambientalista, em muitos casos, se reconhecem incorporando, de

\footnotetext{
${ }^{8}$ O termo "escolarização popular" é, ao mesmo tempo, simples e complicado. Ouvi pela primeira vez esse termo no setor de educação do Centro Ecumênico de Documentação e informação. Depois, Sérgio Haddad e a equipe da Ação Educativa, de São Paulo, o utilizaram para conotar experiências de trabalho de educação popular.
} 
algum modo, o espírito originário e o ideário das práticas atuais da educação popular?.

O Marco de Referência da Educação Popular para as Políticas Públicas (BRASIL, 2014) vai ao encontro da explicação dada pelo professor Brandão e define a EP explicando que

\begin{abstract}
A Educação Popular a um só tempo é uma concepção prático teórica e uma metodologia de educação que articula os diferentes saberes e práticas, as dimensões da cultura e dos direitos humanos, o compromisso com o diálogo e com o protagonismo das classes populares nas transformações sociais. Antes de inserir-se em espaços institucionais, consolidou-se como uma ferramenta forjada no campo da organização e das lutas populares no Brasil, responsável por muitos avanços e conquistas em nossa história. (BRASIL, 2014, p. 7)
\end{abstract}

Os processos que contribuíram para a consolidação do Marco de Referência para a EP demonstram os seus compromissos. Dentre esses processos, a Recid, criada em 2003, como uma ação do Programa Fome Zero, faz a relação entre o governo e a sociedade atuando com centenas de entidades, organizações e movimentos populares, desenvolvendo a EP junto a diferentes grupos historicamente vulneráveis: sem teto, catadores de resíduos sólidos, assentados, acampados, pescadores, comunidades LGBT, dentre outros. Os diálogos e as ações com universidades públicas, centros de educação popular, organizações não governamentais (ONGs) e movimentos sociais brasileiros, por meio de oficinas, seminários, palestras e debates envolvendo a EP, fortalecem a concretização deste Marco. A história da Educação Popular no Brasil é retomada pelo Marco de Referência, por momentos relevantes vividos na luta em defesa dos desamparados pela sociedade e pelo direito de todos à educação. O Marco de Referência retoma essa história mostrando a que ela remete, detalhando vários momentos marcantes.

Retomar o esforço nacional em defesa da Educação Popular como educação do povo quase sempre nos remete às lutas históricas em defesa da escola pública, que advém dos discursos dos liberais desde a primeira República; intensifica-se com outras vozes na década de 1930, por exemplo, por meio do Manifesto dos Pioneiros da Educação Nova; incorpora outros atores sociais nas décadas de 1950 a 1970 , principalmente os movimentos populares e estudantis; sofre a repressão e o silenciamento imposto pela ditadura militar; recupera suas bandeiras históricas no processo de reabertura política do país, sob a liderança do Fórum em Defesa da Escola Pública;

\footnotetext{
${ }^{9}$ A associação dos nomes "popular" e "ambiental” já é suficiente para se compreender o sentido das mudanças sugeridas aqui.
} 
mantendo nas última décadas uma mobilização liderada por instituições públicas, entidades de pesquisas e movimentos sociais organizados que, em diferentes fóruns de debate, ainda insistem na denúncia do não cumprimento constitucional da educação como direito de todos.

A par do reconhecimento de todas essas lutas em defesa da escola pública, esta reconstituição histórica entende que a Educação popular é mais do que isso. Enquanto proposta de educação emancipatória, não se reduz ao espaço escolar, embora o reconheça como estratégico para concretização de outro projeto de sociedade. Portanto, esta concepção de Educação popular se constituiu historicamente na experiência dos movimentos sociais no Brasil, sobretudo no início do século XX, num contexto de lutas de classe e que tinham, dentro do sistema capitalista, a disputa de um projeto alternativo a esse sistema. (BRASIL, 2014, p. 28)

Os caminhos da história vivida pela EA e pela EP estão hoje expressados e registrados pelos princípios construídos ao longo dessa trajetória. Além da história que os originou, também esses princípios mostram o quanto a EA e a EP têm de comum entre elas. A fim de lançar a comparação entre esses princípios, após já ter apresentado os da Educação Popular, apresento agora os da Política Nacional de Educação Ambiental (Lei nº 9.795/99), Capítulo I, que apresenta os seguintes princípios da Educação Ambiental:

Art. $4^{\circ}$ São princípios básicos da educação ambiental:

I - o enfoque humanista, holístico, democrático e participativo;

II - a concepção do meio ambiente em sua totalidade, considerando a interdependência entre o meio natural, o socioeconômico e o cultural, sob o enfoque da sustentabilidade;

III - o pluralismo de ideias e concepções pedagógicas, na perspectiva da inter, multi e transdisciplinaridade;

IV - a vinculação entre a ética, a educação, o trabalho e as práticas sociais;

$\mathrm{V}$ - a garantia de continuidade e permanência do processo educativo;

VI - a permanente avaliação crítica do processo educativo;

VII - a abordagem articulada das questões ambientais locais, regionais, nacionais e globais;

VIII - o reconhecimento e o respeito à pluralidade e à diversidade individual e cultural.

O que observamos ao conferir esses princípios é que a EP e a EA compartilham juntas de uma história de participação nas lutas pela defesa dos direitos, da justiça e da qualidade de vida para todos. O item 9 dos Princípios Básicos da EA, finalizado com o quadro síntese das concepções do processo educativo, nas Recomendações da Conferência de Tbilisi, comentado pelo professor Dias (2003, p. 123), deixa claro que a EA e a EP estão navegando nas mesmas águas.

9. Destacar a complexidade dos problemas ambientais e, em consequência, a necessidade de desenvolver o senso crítico e as habilidades necessárias para resolver tais problemas. 
CA: "Desenvolvimento do senso crítico", como preconizara Paulo Freire, foi o que menos se praticou em nossas escolas, nos últimos vinte anos. Temos o tipo de escola que prepara excluídos, dominados. O sistema é rígido, pouco dado ao diálogo, e os seus conteúdos não lidam com a realidade dos estudantes. Representa o interesse das classes dominantes, ávidas de manter o que está aí, um mundo de assalariados, sem-teto, imersos num quadro de mobilidade social inexistente.

A educação não é neutra. É uma ação cultural. O processo educativo resulta numa relação de domínio ou de liberdade.

Quadro 1 - Educação: processo dominante ou transformador

\begin{tabular}{|l|l|}
\hline \multicolumn{1}{|c|}{ DOMÍNIO } & \multicolumn{1}{c|}{ LIBERDADE } \\
\hline Rígido & Flexível \\
\hline Autoritário & Participativo \\
\hline Avesso ao diálogo & Dialogal \\
\hline $\begin{array}{l}\text { Representa o interesse das classes } \\
\text { dominantes }\end{array}$ & Representa o interesse de todos \\
\hline $\begin{array}{l}\text { Produz professores empenhados em } \\
\text { ter alunos dóceis e passivos }\end{array}$ & $\begin{array}{l}\text { Quer alunos participativos, } \\
\text { questionadores, criativos }\end{array}$ \\
\hline $\begin{array}{l}\text { Aulas formais, conteudistas } \\
\text { (informativas), distantes da } \\
\text { realidade }\end{array}$ & $\begin{array}{l}\text { Conhecimentos da sua realidade } \\
\text { suscitam reflexões, análises, críticas e } \\
\text { autocríticas. Trabalha com formação e } \\
\text { informação }\end{array}$ \\
\hline Objetiva MANTER a situação & Objetiva MUDAR a situação \\
\hline
\end{tabular}
Fonte: Dias (2003)

O percurso traçado neste capítulo foi um esforço para revelar qual diálogo existe e qual diálogo é possível ser feito, ou construído, entre a Educação Ambiental e a Educação Popular. Um empenho também para mostrar a nossa capacidade de superação dos conflitos. A conscientização, a dialogicidade e a resiliência, envoltas na amorosidade, são pilares para a construção de outro mundo. Mesmo assim, se os conflitos existem na sociedade, os fundamentos e princípios da EA e da EP indicam que esses campos devem andar juntos, do mesmo lado, aliados para ampliarem as suas capacidades de lutar por um mundo melhor, mais justo, mais humano e mais natural idealizado por ambos. Um mundo construído sobre os pilares de uma Educação Ambiental Popular. 
Capítulo 2

A alfabetização de adultos nas águas do AJA-Expansão

Figura 8 - "Ler o Mundo, escrever a vida"

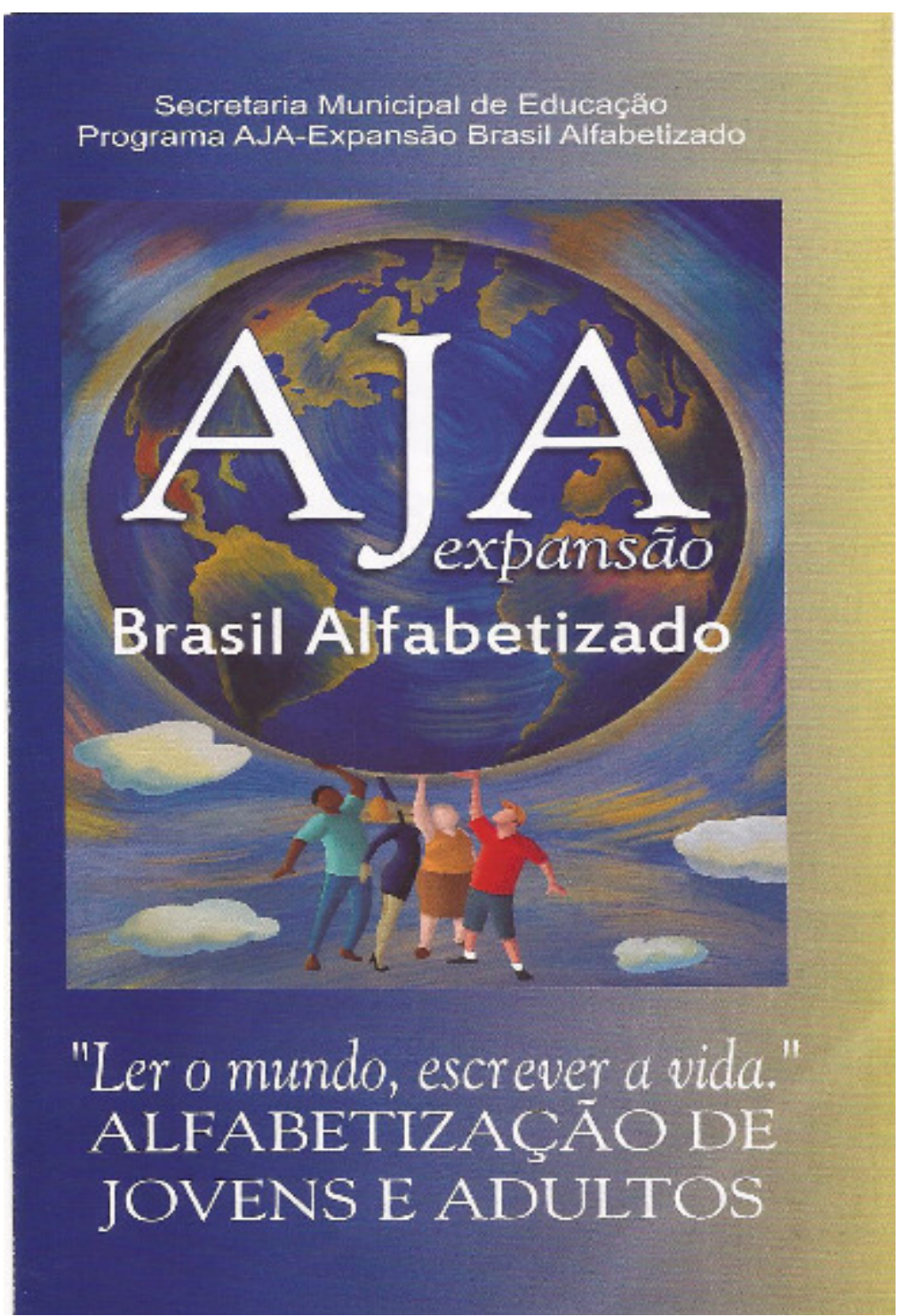

Fonte: Folder do Programa AJA-Expansão. Ano: 2001. 


\section{CAPÍTULO 2 - A ALFABETIZAÇÃO DE ADULTOS NAS ÁGUAS DO AJA- EXPANSÃO}

Ô minha irmã, eu nunca tive escola na minha vida.

Eu nunca tive escola não. Eu tive duas semanas e três dias de escola. Saí da aula e fui pro trabalho foi cedo. Agora eu voltei a criança de novo. Estudar. Agora vou estudar. Com 67 anos, voltei a ser criança. Tô animado.

Seu J

\subsection{Introdução: a força do encontro das águas}

O percurso que venho navegando com esta pesquisa agrega diversos elementos em sua embarcação. Colocar a Educação Ambiental no centro desta discussão, para verificar a sua contribuição em uma aprendizagem significativa na alfabetização de adultos trabalhadores de cooperativa de resíduos sólidos, exige a junção dos campos da Educação Ambiental com a Educação Popular e com essa conexão outros círculos são agregados. Ao fazer esse acoplamento, vou encontrando pontos que os aproximam e outros que os distanciam, embora a experiência vivida junto com os catadores indique que essa aproximação é possível e necessária, por utilizar estratégias da EA enriquecedoras do processo e proporcionadoras de uma experiência que transita do micro ao macrocosmo, buscando uma totalidade integradora, valorizando a subjetividade e ressignificando o pertencimento.

A natureza vem apresentando sinais de seu esgotamento e a humanidade, cada dia mais, se dando conta de que precisa encontrar uma maneira equilibrada de se relacionar com ela, mas o encontro desse equilíbrio requer uma reaproximação do homem à natureza, reduzindo o distanciamento, reconectando as relações. $O$ contexto que hoje se apresenta solicita novos aprendizados para que a vida se fortaleça. Aprendizado para compreender que o homem não é o centro do universo e perceber que a vida se manifesta de muitas maneiras, para viver os sentimentos, para sensibilizar-se, para percorrer os caminhos da subjetividade e do pertencimento. Para ser capaz de construir relações sustentáveis em um mundo de justiça e paz. Em todos esses espaços se localiza a EA, tornando-se indispensável se a escolha for a de trilharmos por outros caminhos. Fonseca e Echeverría (2004, p. 125) comentam a esse respeito dizendo que 
A educação ambiental é, hoje, uma necessidade, diante de uma realidade que apresenta tais situações como: a utilização desenfreada dos recursos naturais pelos processos de industrialização adotados; a exclusão social, com suas consequências nefastas perante a fome, a miséria e a pobreza de grandes populações do planeta e que têm suas raízes, também, no modelo de desenvolvimento implantado e nas bases da relação ser humano - ser humano e ser humano - natureza.

A EA inserida na alfabetização de catadores em Goiânia levou à parceria com o Programa AJA-Expansão, que enriqueceu substancialmente a experiência, suscitando uma diversidade de conexões. Isto foi proporcionado por ele ser ligado a uma rede pública de educação e ao governo federal, trazendo o caráter institucional; pelo acúmulo de experiência em mais de uma década de existência; por possuir uma visão de educação pautada na concepção de educação politizadora, dialógica e libertadora, preconizada por Paulo Freire; por poder fazer a certificação da formação junto aos educandos, dentre outras. Todo esse conjunto de elementos determinou a destinação de um capítulo a esse Programa, retomando a sua trajetória, recontextualizando a sua história, localizando seus compromissos e identificando-os junto à experiência vivida ao longo do período da pesquisa, inserindo-o no campo da Educação Ambiental.

Em 2010, o Programa AJA-Expansão iniciou uma experiência de alfabetização instalando turma envolvendo três cooperativas vinculadas à Incubadora Social da UFG. Essa experiência, embora não tenha obtido um resultado satisfatório, pois nenhuma dessas turmas conseguiu finalizar a formação, foi suficiente para evidenciar ainda mais a percepção da necessidade de uma abordagem mais aproximada dessa realidade, o que me levou a fortalecer o pensamento de que uma abordagem integradora da EA pudesse fazer diferença para essa formação. Interessante observar, nesse contexto, que a proposta político-pedagógica do AJAExpansão traz o pressuposto de uma alfabetização a partir da realidade dos educandos, uma alfabetização construída "com" e não "para" os educandos. Esse pressuposto, mediante a realidade observada, conduz a outras indagações: por que as experiências anteriores do AJAExpansão não foram bem sucedidas? Com quais condições o trabalho foi realizado? A forma como o AJA-Expansão acompanha as atividades teria sido adequada e suficiente para alcançar essa realidade?

Ao longo desse tempo, ficou o desejo de outras tentativas de formação de turmas pela Incubadora, pois a demanda de catadores que não sabem ler e escrever vem cobrando essa iniciativa, mas a realidade dessa demanda possui características bem específicas que requer um atendimento diferenciado do atendimento de alfabetização dispensado a outras comunidades. Portanto, as dificuldades para a estruturação de uma turma e para a 
continuidade da formação ao longo de 8 meses, período determinado pelo AJA-Expansão, e também a falta de pessoas com uma formação específica que se encarregassem das demandas advindas dessa atividade frustraram novas tentativas.

\subsection{Programa AJA-Expansão: a fonte de suas águas}

O Programa AJA-Expansão é, atualmente, o único programa de alfabetização de adultos de Goiânia, vinculado a uma rede pública de educação, a Secretaria Municipal de Educação de Goiânia (SME), e subsidiado com verbas do governo federal, por meio do Programa Brasil Alfabetizado (PBA). Ele está inserido na "Proposta Político-Pedagógica da Educação de Adolescentes, Jovens e Adultos" da SME de Goiânia, sendo parte da diversidade dos atendimentos direcionados pela SME para essa modalidade de educação. Possui, portanto, princípios, objetivos e metas nascidos de uma movimentada história de avanços e recuos, de enfrentamentos e superações. Nesse contexto, para falar do AJA-Expansão, é importante adentrar na fonte das águas da sua história, porque a sua história revela a visão que o originou.

A história do AJA-Expansão é proveniente da história da SME de Goiânia e,nela, da história do projeto AJA. Interessa recontar aqui uma parte dessa história, a fim de buscar os canais da espiral que conduz e une a seiva que envolve o leito dessas águas. A cada reconto há uma recontextualização que nasce do momento histórico onde novas pegadas estão fazendo suas marcas. Assim, trazer essa história justifica a caminhada e fortalece o pertencimento, localizando o ambiente de onde provêm as águas movimentadas com o objeto desta pesquisa.

Opto por iniciar esse reconto trazendo Clímaco (2004) pela relevância de sua pesquisa acerca do processo de criação dessa Secretaria, fazendo importante registro de uma história impregnada de relações clientelistas. E concordo quando ela diz que é relevante "também pelo fato de que as questões centrais ali abordadas - clientelismo e cidadania - continuam presentes em nosso cotidiano." (CLÍMACO, 2004, p. 32) Até 1961 as administrações de Goiânia e do estado de Goiás não se separavam. A justificativa, segundo essa pesquisadora, para essa situação foi atribuída à reduzida população do município, àquela época com 150 mil habitantes, e outra forte motivação é atribuída ao fato de que até esse período os titulares administrativos eram copartidários. Em 1959, foi criado o Departamento Municipal de Educação e Cultura que, em 1961, foi transformado em Secretaria Municipal de Educação e Cultura, iniciando um difícil processo de separação física e administrativa entre os poderes municipal e estadual, para a consolidação da autonomia dessa secretaria. 
Somente após mais de 3 décadas, com a promulgação da Lei de Diretrizes e Base da Educação, em 1996, a Secretaria Municipal de Goiânia foi impelida a construir seu próprio sistema, que até então ainda estava sendo normatizada pelo Conselho Estadual de Educação (CEE). Essa nova Lei atribui aos municípios a responsabilidade pelo Ensino Fundamental. Por essas vias, em 1997, foi criado o Conselho Municipal de Educação (CME), que passou a regulamentar as diretrizes que norteiam o funcionamento do Sistema Municipal de Ensino, incluindo a EAJA. Mas, e o Programa AJA-Expansão, onde se localiza nessa história? É importante conhecermos o percurso da SME até a chegada a esse Programa, para que se compreendam os seus propósitos e compromissos.

O clientelismo foi uma marca muito forte no sistema educacional de Goiânia. Até a década de 1980, quando se iniciaram os concursos para a contratação de professores e funcionários administrativos, essa ainda era a prática comum à qual as pessoas precisavam recorrer para ter seus direitos atendidos na forma de "favores". Recorriam a vereadores e deputados para conseguirem uma vaga para matricular os filhos em alguma escola, assim como a contratação dos professores e funcionários e a indicação dos diretores, da mesma forma, tudo era feito somente pela determinação dos políticos, sem nenhuma exigência de habilitação específica para o exercício da docência. Até mesmo os aspectos didáticopedagógicos e disciplinares eram influenciados pelas interferências dos políticos. Além de comum, essa era uma prática naturalizada onde a cidadania era exercida pela via do voto, elegendo aquele que fosse mais "generoso".

Era, portanto, uma relação de prevalência clientelista. Há que se considerar que o clientelismo é uma relação ainda muito presente nos dias de hoje, se manifestando de novas maneiras e confirmando o quanto essa relação está estreitamente vinculada à conquista da cidadania. Ou seja, quanto menor for a conquista da cidadania, maior se torna a relação clientelista. Ou ainda, o clientelismo é uma força que extingue a cidadania e oprime a existência do cidadão possuidor de direitos.

Clientelismo supõe a inexistência de direitos garantidos, supõe a substituição de direitos por favores. [...] No Brasil, os direitos dos indivíduos, ainda que garantidos em lei, na verdade são de difícil concretização, uma vez que a generalização dos direitos entra em confronto com um modo tradicional de organização social extremamente hierarquizado e intolerante para "com os usos socialmente construtivos do conflito", para usar uma expressão cara a Florestan Fernandes. A cultura do "favor", do "jeitinho", está tão presente entre nós que, muitas vezes, para usufruir de um direito óbvio, recorre-se à interferência de uma pessoa influente para obter um determinado "favor". [...] Cidadania supõe, pois, não só que os indivíduos sejam portadores de direitos, mas, sobretudo, que os indivíduos participem da construção, da 
definição e da fruição desses direitos, independentemente da mediação de um padrinho. (CLÍMACO, 2004, p. 32)

O contexto que vivemos atualmente, reafirmado pelas dificuldades encontradas para a constituição da turma desta pesquisa, indica que não basta ter políticas públicas, além das políticas é preciso que as condições sejam produzidas para a sua efetivação, sob o risco de criar novas faces para o clientelismo. Nesse contexto, a trajetória vivenciada pela SME de Goiânia apresenta um percurso que vai da relação clientelista à implementação de propostas educacionais democráticas e com princípios que indicam alternativas para o atendimento específico à demanda dos educandos adolescentes, jovens e adultos. A cidade de Goiânia, no período de 1993-1996, foi administrada por uma gestão que se apresentava como democrático-popular e buscava comprometer-se com o atendimento às necessidades do povo. Nesse período, é criado na SME de Goiânia um atendimento alternativo denominado Experiência Pedagógica de $1^{\mathrm{a}}$ a $4^{\mathrm{a}}$ Séries do Ensino Fundamental para Adolescentes, Jovens e Adultos, conhecida como Projeto AJA, ou seja, uma experiência que buscava uma maneira diferente da educação formal, mas que fosse específica e próxima da realidade dos educandos atendidos. Trata-se de uma experiência alternativa, que gerou grande influência para o atendimento a essa demanda até os dias atuais.

O Projeto AJA, por sua vez, se originou de uma experiência de alfabetização desenvolvida, em 1992, na Faculdade de Educação (FE) da Universidade Federal de Goiás (UFG) intitulada "Intenção de Estudo: experiência com adolescentes de $1^{\mathrm{a}}$ a $4^{\mathrm{a}}$ série de $11 \mathrm{a}$ 17 anos". Para essa experiência, foram instaladas nessa FE duas turmas de vinte adolescentes e jovens analfabetos. Esse projeto ficou conhecido com o nome "Alfabetização para meninos e meninas de rua", embora essas turmas estivessem constituídas por meninos de rua, adolescentes de classe média com dificuldades escolares e disciplina, além de adolescentes da periferia. (RODRIGUES, 2000, p. 65)

Por falta de estrutura física adequada e pela necessidade de ampliação do atendimento, em 1993 a experiência foi transferida para a SME, quando uma nova equipe toma posse nessa secretaria e a professora coordenadora do projeto na FE/UFG passa a fazer assessoria na SME. Esse movimento dá origem ao "Projeto de Experiência Pedagógica de $1^{\mathrm{a}}$ a $4^{\mathrm{a}}$ série do ensino fundamental para adolescentes, jovens e adultos" que ficou sendo conhecido como "Projeto AJA". Iniciado em 12 escolas da Rede Municipal de Educação (RME), o Projeto AJA apresentou resultados satisfatórios no caminho de superação de problemas históricos como a evasão e a repetência, além do fortalecimento do trabalho em equipe e do envolvimento dos educandos e educadores tanto no desempenho das atividades, como em sua 
própria formação. (MACHADO, 2004; RODRIGUES, 2004). Sobre os princípios do Projeto AJA Rodrigues (2004, p.159) comenta que

O Projeto AJA (...) retoma características da educação básica construída pelas camadas populares na década de 1960, resgatando o conteúdo político das propostas ali desenvolvidas, tendo em vista a sua incorporação no seio da RME. Objetivando trabalhar com adolescentes, jovens e adultos excluídos da escola por falta de condições, repetências sucessivas, inadequação à metodologia infantilizada ou por indisciplina (...).

O Projeto AJA, portanto, vive uma experiência transformadora e, por essa razão, desafiadora gerando situações novas e inesperadas para a própria SME que o propôs. Ao longo do trabalho, a equipe de professores e técnicos que com ele se envolveu foi se aprofundando em estudos e discussões em busca de compreender melhor em que consistia um trabalho educacional dirigido aos jovens e aos adultos. Perceberam, dentre outras coisas, que a educação para esses sujeitos deve ser uma educação construída com eles e não para eles. Em decorrência desse entendimento, outros foram surgindo mudando a compreensão de currículo, transformando a avaliação, alterando horários, ressignificando tempos e espaços, esbarrando, enfim, pois, nos próprios limites da estrutura da SME. "Nesse sentido, o Projeto AJA se depara com os limites impostos pela estrutura da própria instituição que o propõe". (MACHADO, 2004, p. 189)

Dentre as contribuições significativas, trazidas pelo movimento iniciado pelo Projeto AJA, destaca-se a experiência de círculos de cultura. Círculo de cultura foi a denominação dada aos grupos de alfabetizandos nas experiências realizadas por Paulo Freire. Essa experiência foi recontextualizada no Projeto AJA, em Goiânia, onde a formação desses círculos tinha o propósito de localizar os educandos e trazê-los para uma roda onde tivessem o contato com a leitura e a escrita, numa perspectiva emancipadora, a fim de despertar nesses educandos o desejo de retornar ou iniciar, em alguns casos, sua formação escolar. Cunha, Rodrigues e Machado (2007, p. 22) explicam como foi feita essa experiência no Projeto AJA, assim:

Os Círculos de Cultura, aos moldes dos anos de 1960, foi um movimento de alfabetização popular implementado em Goiânia, no período de agosto de 1993 a dezembro de 1996, que surgiu quando a SME firmou convênio com a Confederação Nacional dos Bispos do Brasil/Movimento de Educação de Base (CNBB/MEB), com o objetivo de buscar os alunos que não estavam procurando as escolas e criar neles o desejo de estudar, mobilizando-os por meio do processo inicial de alfabetização e elevação da auto-estima. No início foram abertos 30 Círculos de Cultura, sendo 14 vinculados a entidades religiosas, 6 a associações de moradores, 5 a sindicatos e 5 a empresas 
públicas. Eles funcionavam em três dias semanais alternados - segunda, quarta e sexta -, num período mínimo de duas horas em cada encontro. As/os monitoras/es eram aducadoras/es populares indicados pelos parceiros. A formação das/os monitoras/es para atuar nos Círculos de Cultura era realizada pela SME, em parceria com o MEB, sendo que, nas trocas de experiências, tinha o/a educador/a observador/a que auxiliava na formação de ambos.

Em 2001 uma nova gestão que se apresentava como democrático-popular tomou posse na prefeitura de Goiânia. A equipe que assume a SME, nessa gestão, reelabora toda a proposta educacional colocando o aluno no centro das atividades. Essa mudança provocou o distanciamento a procedimentos seletivos baseados em seriação, notas, reprovação e ênfase no conteúdo, promovendo a aproximação com uma prática que valorizasse as vivências, a cultura e os saberes dos educandos, um exercício que promovesse a inclusão social e a educação como direito.

Afirmando-se embasado em compromissos democrático-populares, o grupo que assumiu a SME no período 2001-2004 fortalece o Projeto AJA e elabora uma proposta político-pedagógica estendendo esses princípios a toda EAJA da RME. Ou seja, a todo o ensino fundamental da educação de adolescentes, jovens e adultos, da $1^{\mathrm{a}}$ à $8^{\mathrm{a}}$ série, dessa rede municipal de educação. Essa incorporação vai demandar muitas mudanças e em 2001 a SME decide pela realização de uma pesquisa intervencionista para elaborar coletivamente uma proposta que responda aos anseios dos sujeitos que fazem a EAJA, intitulada: "A construção de uma proposta democrático-popular de Educação para Adolescentes, Jovens e Adultos (EAJA) da rede municipal de educação de Goiânia, pelos sujeitos do processo educativo". Observa-se que a movimentação no interior dessa SME vem em resposta também aos movimentos de emancipação desencadeados no país desde os anos de 1980.

O Brasil, a partir dos anos 1980, vive uma grande movimentação de redemocratização do país, decorrente da luta pelas eleições diretas e o final da ditadura militar. No bojo desse movimento é buscada pela SME de Goiânia, mais especificamente na educação de jovens e adultos, uma experiência que superasse a visão utilitarista e mercantilista da educação do jovem e adulto. Com essa intenção, a experiência popular vivida nos anos 60, ou seja, a experiência implementada pelo professor Paulo Freire é retomada, mas em uma desafiadora reconfiguração para inserí-la em uma rede educacional. Assim, são empreendidos esforços por essa SME para que a inserção dos princípios de uma educação libertadora, transformadora e comprometida com as questões sociais fosse recontextualizada e materializada em um novo contexto histórico social. 
A inserção dos princípios teórico-filosóficos da proposta pedagógica do Projeto AJA provocaram um conjunto de mudanças. Rodrigues (2004, p. 160-161) acrescenta ainda alguns desdobramentos acerca da vivência proporcionada por esses princípios, norteadores do Projeto AJA, explicando que:

A vivência desses princípios, a flexibilidade de horários e frequência, bem como a utilização de uma proposta de ensino-aprendizagem pautada no diálogo, na utilização de temas geradores, na ação conjunta de educandos e educadores para a construção e reconstrução de saberes significativos, numa perspectiva interdisciplinar, configuraram-se em avanços na RME, que iniciou o projeto AJA, em 1993, com 12 turmas experimentais e, em 2001, já contava com 186 turmas. Vale dizer, em 2002, os princípios e avanços nele vivenciados foram estendidos às demais turmas de EAJA, do ensino fundamental da RME de Goiânia. (RODRIGUES, 2004, p. 160-161)

O resultado apresentado pelo Projeto AJA nas 12 turmas experimentais fez com que essa experiência fosse aos poucos se expandindo às outras escolas da RME. Essa foi a primeira conotação dada à expressão "expansão", pois esse Projeto, além de estender-se às demais escolas da RME, também a partir da década de 90 expande-se pelo atendimento da alfabetização de adultos à continuidade dessa concepção de escolarização por todo o ensino fundamental destinado à EAJA nessa RME e, a partir de 2001, com o início de uma nova gestão é criado o projeto AJA-Expansão. Um programa instituído por essa SME para atendimento à grande demanda de adultos privados da habilidade de leitura e escrita na cidade de Goiânia.

A partir de agosto de 2001, a rede pública municipal de educação, mediante
parcerias com outros órgãos públicos municipais, estaduais ou federais, e
com organismos da sociedade civil, propõe-se a efetivar a expansão do
referido projeto AJA, estruturando turmas com organização de carga horária
diferenciada e atendidas por educadores populares, originados da própria
comunidade. (GOIÂNIA, 2002, p. 25 )

De acordo com o Censo do Instituto Brasileiro de Geografia e Estatística (IBGE), no ano 2000 Goiânia possuía 5,7\% de pessoas não alfabetizadas, aproximadamente 45.000 habitantes. Garantir sala de aula para todas essas pessoas foi o maior desafio ao qual a equipe da SME, gestão 2001-2004, se lançou. Foi na tentativa de enfrentar esse desafio que, em 2001, é criado o Programa AJA-Expansão. Este inicia seu atendimento com subsídios do Tesouro Municipal, fazendo parceria com o governo federal a partir de 2003, quando passa a ser denominado Programa AJA-Expansão/Brasil Alfabetizado. Atualmente, ele conta somente 
com o financiamento do governo federal por meio do Programa Brasil Alfabetizado (PBA), dependendo, a cada ano, da liberação do governo federal para a abertura de turmas.

Em 2001, a equipe que assumiu a SME, buscando uma estrutura que correspondesse à concepção de educação "participativa e transformadora" Goiânia (2002, p. 25) que estava apresentando, criou uma nova composição e transformou o Departamento de Ensino em Departamento Pedagógico. Ao mesmo tempo, instituiu várias divisões vinculadas a esse Departamento Pedagógico, dentre elas, a Divisão de Educação Fundamental de Adolescentes, Jovens e Adultos (DEF-AJA).

Pensando uma estrutura que favoreça a construção da educação inclusiva, a nova administração, no ano de 2001, instituiu como parte integrante do Departamento Pedagógico, antigo Departamento de Ensino, a Divisão de Educação fundamental de adolescentes, de jovens e de adultos.

Essa Divisão, a partir de então, juntamente com as demais divisões, Unidades Regionais de Educação e o Centro de Formação dos Profissionais de Educação, pretende buscar caminhos que efetivem, na rede municipal de educação de Goiânia, uma concepção de educação participativa e transformadora, compatível com as expectativas da comunidade educacional (educadores, educandos, pais de alunos e moradores locais).(GOIÂNIA, 2002 , p. 24 e 25)

O Programa AJA-Expansão foi criado pela SME de Goiânia como uma ação necessária para o cumprimento da difícil meta estabelecida, pela própria SME, de alfabetizar todos os adolescentes, jovens e adultos que ainda se encontravam privados do domínio da leitura e da escrita na cidade de Goiânia. Essa foi uma meta tomada como "Prioridade de Governo" Goiânia (2001) e uma atividade relevante, pois desse atendimento foi possibilitado criar nos educandos o desejo de dar continuidade à escolarização remetendo-os à EAJA de $1^{\text {a }}$ à $8^{\mathrm{a}}$ séries, alimentando e criando outras demandas na EAJA de toda a RME. Por meio do Programa AJA-Expansão "a SME se propõe a alfabetizar, no período de 2001-2004, os presumidos quarenta e cinco mil analfabetos adolescentes e adultos existentes em Goiânia". Goiânia (2002, p.4) Para o cumprimento dessa meta a SME apresenta um documento embrionário do Programa AJA-Expansão denominado: "PROJETO AJA - A Educação fazendo sua parte", Goiânia (2001) onde apresenta (p.35) a seguinte tabela de projeção de suas intenções: 
Quadro 2 - Projeção de intenções do Projeto AJA

\begin{tabular}{|l|c|c|c|}
\hline \multicolumn{4}{|c|}{ DADOS DE ANALFABETISMO: aproximadamente 45.000 pessoas acima de 15 anos } \\
\hline \multirow{2}{*}{ ANO } & ALUNOS & TURMAS & EDUCADORES \\
\hline $\mathbf{2 0 0 1}$ & 5.000 & 200 & 200 \\
\hline $\mathbf{2 0 0 2}$ & 15.000 & 600 & 600 \\
\hline $\mathbf{2 0 0 3}$ & 15.000 & 600 & 600 \\
\hline $\mathbf{2 0 0 4}$ & 10.000 & 400 & 400 \\
\hline & & & $\mathbf{6 0 0}$ \\
\hline
\end{tabular}

Fonte: Programa AJA-Expansão. Ano 2001.

O Censo do IBGE 2010 apresenta um percentual de 3,3\% de analfabetismo em Goiânia. Por esse dado, observa-se que houve uma redução significativa do percentual de analfabetismo, embora bem distante da meta almejada, mas observa-se também que esse é um rio caudaloso e de águas turbulentas, difícil de navegar. São muitas pedras nesse leito para serem contornadas: a localização dos educandos é a maior delas, saber quem são e onde estão, outro obstáculo é convencê-los de seu direito a estudar e há, ainda, a necessidade de mobilizações nos bairros e estabelecimento de parcerias. Além desses obstáculos há outras situações que se originam do contexto de cada lugar. Considerando todas essas dificuldades, há que se reconhecer o esforço para o alcance da meta à qual a SME se propôs, mas sabemos que esse é um terreno de grande complexidade, abrangendo muitos elementos, de diversos espaços sociais.

Esse resultado confirma que o analfabetismo é uma expressão da estrutura social perversa que sucumbe a vida e aniquila os sonhos, lembra também que ler e escrever são para quem tem um lugar na sociedade e que essa realidade não muda sozinha, isoladamente. Para haver mudança, o investimento tem que ser grande, o esforço tem que ser contínuo, o empenho tem que ser forte e o compromisso permanentemente realimentado na relação dialética transformadora da realidade geradora da exclusão, da fome, da ignorância, da submissão do ser às condições desumanas da vida.

Mobilizada por esse contexto de difícil superação, procurando maneiras novas de intervir nessa realidade é que me lanço nessas águas. Assim, me arremesso a inventar estratégias de EA, apostando nas possibilidades de contribuir para a obtenção de melhores resultados, sem preocupações com estatísticas oficiais, mas comprometida, principalmente, 
em demonstrar o que a Educação Ambiental pode proporcionar para a melhoria da qualidade de vida para os que com ela reaprendem a estar no mundo. O quadro apresentado pelo documento de avaliação do Plano Municipal de Educação (PME), Goiânia ${ }^{10}$ (2015, p. 3) traz dados que confirmam a drástica redução dessa demanda por alfabetização:

\section{RENDIMENTO ESCOLAR DOS PROGRAMAS DE ALFABETIZAÇÃO DE JOVENS E ADULTOS NO MUNICÍPIO DE GOIÂNIA, POR DEPENDÊNCIA ADMINISTRATIVA, 2004-2013}

Quadro 3 - Redução da demanda por alfabetização no município de Goiânia

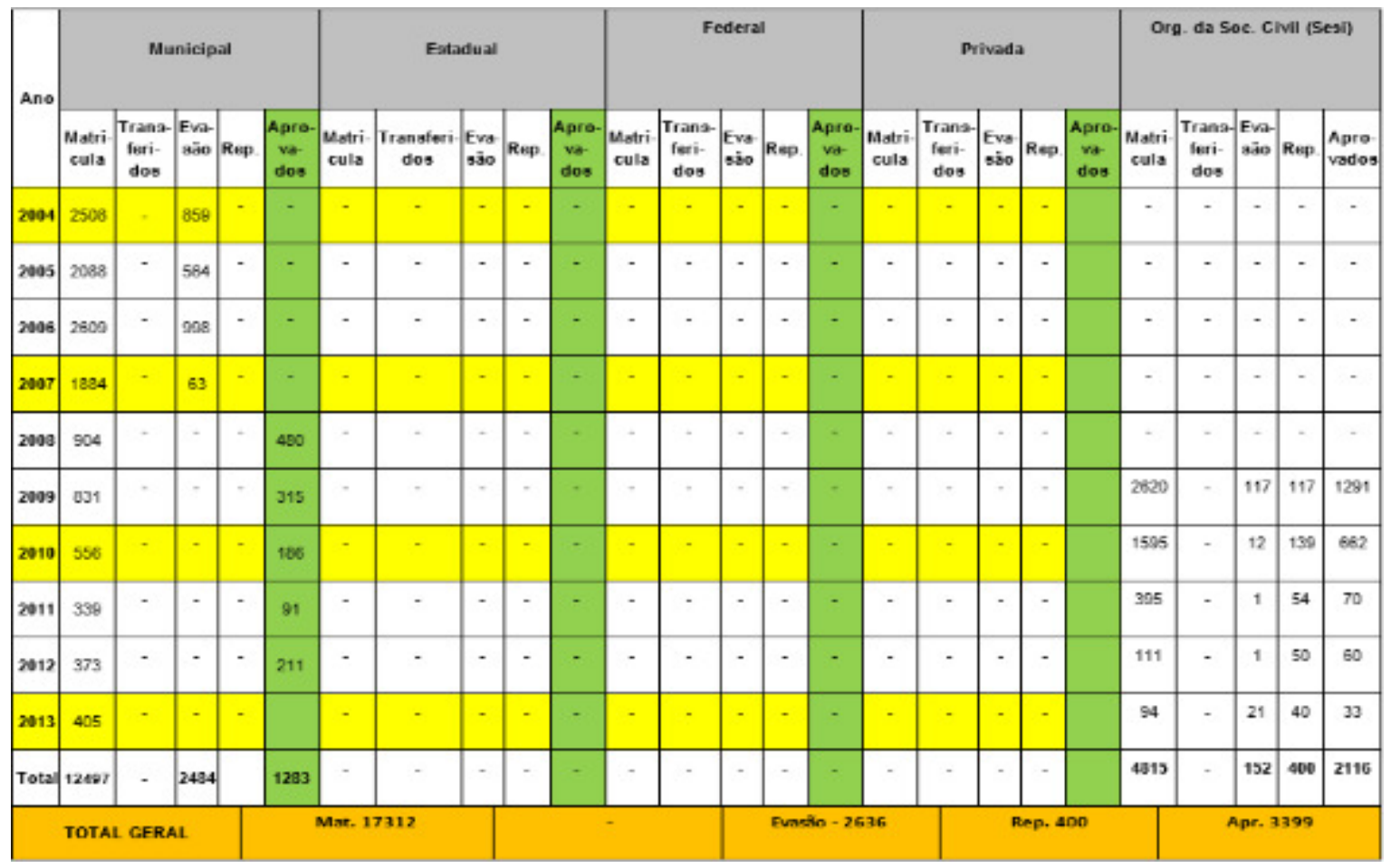

Fonte: Dados de rendimento escolar da SME de Goiânia e Sesi no PME. Ano: 2015.

Observa-se, por essa tabela, que ano a ano o atendimento a essa demanda tem se reduzido. Dos mais de cinco mil alunos atendidos em 2001 e em 2002, com aproximadamente 300 turmas a cada ano, vê-se que essas turmas foram reduzidas numa proporção maior que a do percentual de educandos alfabetizados. Em 2014, ano em que participei com a turma constituída para a realização desta pesquisa, foram formadas inicialmente 24 turmas, mas

\footnotetext{
${ }^{10}$ Texto produzido pela Comissão de Educação de Jovens e Adultos, composta pela equipe de sistematização: Maria Emilia de Castro Rodrigues - Fórum Goiano de EJA e UFG (coord.), Cláudia Borges Costa - SME Goiânia e Fórum Goiano de EJA, Maria Jacqueline Dias Alves - SME Goiânia; além dos integrantes: Esmeraldina Maria dos Santos - SME Goiânia, Marisa Claudino Costa Barbosa- DEF-AJA, Ramon Marcelino R. Jr. - IFG, Jackelyne de Souza Medrado - Sesi, Cecília Torres Borges - SME Goiânia, Vanira Victorino - Condir, Augusto César de Azevedo - Seduc, Rosemeire B. Santos Carvalho - Seduc; Orita de Souza Medrado - Seduc.
} 
finalizou com 14 turmas e pouco mais de 100 educandos. Em contrapartida, os dados apresentados pelo IBGE indicam que a demanda existe e está fora da escola. Na introdução da “Avaliação da Educação de jovens e Adultos no Plano Municipal de Educação de Goiânia 2004-2014" (GOIÂNIA, 2015, p. 1) os dados apresentados confirmam a demanda.

Conforme o censo de 2010, os dados fornecidos pelo Instituto Brasileiro de Geografia e Estatística-IBGE ${ }^{11}$, a cidade de Goiânia computava uma população de 1.302.001, sendo que 1.296 .969 pessoas situavam-se no meio urbano e 4.926 no meio rural, tendo como atividades básicas o comércio e a prestação de serviços. Deste total da população temos 1.031 .094 pessoas acima de 15 anos de idade, e de acordo com IBGE/2010, 28,5\% dessa população não possui ensino fundamental completo e $19,4 \%$ possui ensino fundamental completo e ensino médio incompleto. A população estimada para 2014, segundo o IBGE é de 1.412.364 habitantes.

Em 2015 não houve formação do AJA-Expansão por falta de financiamento do PBA, informação essa dada pela DEF-AJA. Encurtou a verba, mudou a prioridade de governo, federal e local, diminuiu o percentual de educandos na escola. No ano de 2014, durante esta pesquisa, faltou composição de pessoal suficiente na DEF-AJA para percorrer os quatro cantos da cidade a fim de conhecer mais de perto e atender as peculiaridades de cada comunidade, faltou a garantia de estrutura para a instalação de turmas em cada comunidade necessitada. Houve sinais de preterição ao Programa AJA-Expansão que se manifestaram de diversas maneiras, durante a pesquisa de campo que realizei em 2014. Uma realidade que me chamou a atenção, causando-me surpresa. Por conhecer a história que deu origem ao AJAExpansão, por considerar a relevância de sua existência e os princípios com os quais se compromete, sempre imaginei que a SME o tivesse em grande consideração e atencioso cuidado.

Em agosto de 2014 a DEF-AJA promoveu o III Simpósio da EAJA, intitulado "O currículo e suas dimensões: relato de experiências das escolas da RME de Goiânia”. Para esse Simpósio foram convidados todos os segmentos dos diversos atendimentos que até aquele ano a DEF-AJA vinha desenvolvendo: AJA Alternativo, Ensino Fundamental EAJA $1^{\text {a }}$ fase e $2^{\text {a }}$ fase, Proeja FIC. Somente o AJA-Expansão não foi convidado para apresentar a sua experiência. Investida do espírito de pesquisadora, eu fui ao Simpósio. Quando ao final, abriram para perguntas dos professores que compunham a plateia, não pude me conter: falei para os colegas sobre o AJA-Expansão, pois são muitos os novos professores que não

11 Esse dado é uma elaboração realizada a partir dos microdados do Censo 2010, fornecidos pelo IBGE. 
conhecem das experiências e sobre a história da EAJA nessa rede, e comentei de meu estranhamento por ele não ter sido convidado para o Simpósio. Ninguém explicou, outros assuntos foram colocados em discussão. Notei que o Programa que um dia foi "Prioridade de Governo", agora é deixado fora dos relatos importantes das experiências realizadas pela DEFAJA. Ao que podemos entender, o AJA-Expansão traz com ele a parte mais rica e significativa da história da EAJA da SME de Goiânia e uma ação relevante perante a sociedade. Deixá-lo fora desse Simpósio é deixar de contar essa história, é omitir a origem da concepção pedagógica que a orienta. O Programa que foi "Prioridade de Governo", hoje não é sequer convidado para um Simpósio de EJA organizado pela mesma Divisão que sempre o atendeu. Parece que o cisne se tornou patinho feio.

A estrutura de atendimento à EAJA na SME de Goiânia foi adquirindo uma forma muito diferente da estrutura de atendimento dada às turmas do ensino regular. Essa maneira própria de se estruturar é resultado da história vivida pelos sujeitos envolvidos com essa realidade, na defesa e construção de um atendimento que acolha as especificidades desses educandos. Mas a realidade é dinâmica e as tensões são contínuas exigindo constantes mudanças. A redução de turmas na modalidade EJA, na SME de Goiânia, vem acontecendo ano a ano e, com o esvaziamento das escolas, a SME é impelida a se movimentar em busca de maneiras de superação do problema. Mediante as exigências decorridas dessa realidade, em janeiro de 2016, a SME apresenta a toda a sua comunidade educacional um projeto de atendimento à EAJA intitulado: Orientações Preliminares Sobre a Nova Estrutura da Educação de Adolescentes, Jovens e Adultos para 2016. (GOIÂNIA, 2016)

Com essa proposta, novas discussões estão em curso na SME e no Conselho Municipal de Educação de Goiânia (CME), pois ela reduz de 8 para 5 anos a educação fundamental para a EAJA. Essa redução parece caminhar na contramão do movimento histórico de conquistas de espaço para essa modalidade dentro da SME e traz pressões que recaem sobre os sujeitos envolvidos, equipe gestora, educadores e, especialmente, os educandos, pois estes terão os seus tempos e espaços, dessa maneira, reduzidos na EAJA. Observa-se que, com essa medida, a SME, ao invés de olhar para a realidade buscando o atendimento a esses sujeitos, promovendo estudos, discussões, seminários e apontando novos caminhos para uma realidade que se agrava cada dia mais em Goiânia, em Goiás e no Brasil, ela age com uma prática já conhecida, baseada em medida de gabinete a partir de "estudos de rede", direcionada a reduzir gastos e aumentando ainda mais o distanciamento à escolarização dos educandos jovens e adultos trabalhadores. Entende-se que encurtar o tempo, no mundo da EJA, é aligeirar o atendimento, e que aligeirar é tirar desses sujeitos o direito a uma educação 
que lhes permita trilhar todos os espaços dos conhecimentos produzidos pela humanidade e poder se fazer sujeito no ambiente da ciência. É subjugá-lo à condição da sobrevivência humana, Arendt (2008) alimentando a cadeia de um modelo social injusto, excludente e devastador do homem e da natureza.

As pressões são muitas e o movimento vai se fazendo em constante oscilação entre avanços e recuos, mas desde que a SME iniciou a experiência com o Projeto AJA, na década de 1990, nota-se um crescimento de tempos e espaços se concretizando na RME de Goiânia na busca do atendimento específico para a modalidade de EJA. Inclusive, uma força que se considera que contribuiu para assegurar as conquistas ao atendimento a esses sujeitos foi a permanência da equipe de EJA da SME, mesmo com as mudanças dos prefeitos e secretários de educação. A troca de algum membro, de tempos em tempos, sucessivamente foi determinada por questões pessoais do próprio percurso da vida, que por determinações políticas. Nessas mesmas "Orientações Preliminares" a DEF-AJA foi transformada em "Gerência de Educação de Adolescentes, Jovens e Adultos - GEAJA”. Se olho para a própria coerência interna do processo, ela parece me dizer que há uma intencionalidade. Senão, por que essa mudança? Mas qual será a intenção? Estará a SME querendo mostrar aos antigos sujeitos da DEF-AJA e a todos envolvidos nas novas orientações, que a estrutura que os insere mudou, evidenciando um novo lugar?

São muitas as questões, tantas mais quanto mais se adentrar nas estruturas sociais geradoras da exclusão, da fome, da ignorância, da subserviência. Quais são, então, as forças que arremessam a esse movimento de redução dos educandos nas escolas? Por que esses educandos estão se afastando da escola? As estatísticas revelam o grande número de jovens e adultos fora da escola, que não concluíram o ensino fundamental, nos fazendo ver que o esvaziamento das escolas e do atendimento à modalidade EJA não é uma realidade exclusiva de Goiânia, mas um fenômeno que está sendo vivido em todo o país. Uma circunstância de forças confrontadas no desencontro de águas turbulentas. A compreensão desse fenômeno envolve uma conjuntura complexa, geradora de tema para muitas investigações, mas indicadora, sobretudo, de que a escola desses sujeitos ainda não foi inventada.

\subsection{A parceria entre o curso e o percurso}

O contexto histórico da alfabetização de adultos em Goiânia abre diversas possibilidades de abordagem para esse estudo: no âmbito de política pública, formação continuada, didático-pedagógica dentre outras. No entanto, embora seja um projeto bem 
elaborado pela equipe da SME de Goiânia, observei a falta de referência da educação ambiental em suas proposições, o que me alertou para a necessidade da inserção de vínculos com essa discussão. Toma-se, portanto, o aspecto didático-pedagógico como foco desta pesquisa, por sua relação direta com os sujeitos envolvidos no processo. Essa abordagem, além de possibilitar a inserção da Educação Ambiental com estratégias ecopedagógicas que promovam o trabalho de consciência ambiental junto aos educandos da cooperativa ACOP em processo de alfabetização, direciona o olhar para outra perspectiva de atuação a partir da sensibilização, da percepção do ser, da expansão da vida.

A longa e conflituosa história da alfabetização de adultos no Brasil e o acúmulo de discussões e produções existentes que subsidiam o Programa AJA-Expansão da SME de Goiânia são elementos que lhe possibilitam enfrentar os desafios e contribuir para a construção de uma nova história da alfabetização de adultos no Brasil. Nesse contexto, considero que a EA pode trazer contribuições significativas para interferir junto a essa situação de grande evasão dos educandos da EJA que está se apresentando hoje em Goiânia e em todo o país. É uma situação que traz novos desafios, que exige novas maneiras de serem olhados e cuidados.

A concepção de educação que envolve a EA não se contrapõe à concepção de educação que orienta a EP, mas a EA revela a natureza complexa que envolve a alfabetização de adultos colocando em foco nesse processo uma relação integrada com a natureza. A EA busca integrar o homem à sua natureza e à natureza da natureza reaproximando-o, levando o ser humano a se perceber parte da natureza, inserido em seu sistema de alimentação da vida. Nesse caminho, ela vai ao encontro das emoções, da sensibilidade, das subjetividades, criando uma relação diferente daquela que vê a natureza como matéria prima para ser explorada, da que coloca a natureza a serviço do homem. Por meio da sensibilização, ela busca a reaproximação consigo mesmo, localizando o pertencimento e resgatando a identidade para tornar-se sujeito consciente e capaz de realizar transformações que alimentem a vida. Sato e Passos (2013, p. 24) aprofundam essa reflexão comentando que

$\mathrm{Na}$ dimensão político-poética da EA, não há orientações pedagógicas magistrais de receitas prontas, cartilhas que promovam o $\mathrm{ABC}$ de estratégias, ou bússolas que mostrem apenas um eixo "norteador" do universo, senão um conjunto de tentativas e erros, com acúmulo de dissabores e que muitas vezes nem alcançam a beleza da flor. A educadora ou o educador ambiental situa-se, assim, num enigmático mundo de descobertas, com dúvidas sobre por onde caminhar ou sobre qual itinerário seguir. 
Seguindo a correnteza que conduz estas águas, teço esta trama com as pontas soltas dos fios escorridos do tecido encontrado. O Programa AJA-Expansão/Brasil Alfabetizado possui uma estrutura organizacional para a formação e a prática das atividades com as turmas, tanto internas quanto externas, por meio da qual implementa toda a elaboração para o atendimento aos educandos. A essa estrutura inseri a turma da pesquisa e acredito que, assim como houve para essa turma uma relação específica entre ela e a estrutura de atendimento proposta, também para cada turma que aí se forma há uma relação peculiar decorrente das características de cada comunidade atendida. Assim, apresento a estrutura organizacional da proposta de trabalho do AJA-Expansão onde se inseriu a experiência vivida nesta pesquisa, para em seguida contar como ela aconteceu. É importante lembrar que a relação com o AJAExpansão é apenas uma das dimensões do universo abordado, outras extensões desse universo estão localizadas nas cooperativas contatadas, no apoio recebido da Incubadora Social da UFG, nas parcerias com Ong e com professor de artes, dentre outras.

A Proposta Político Pedagógica da Educação de Adolescentes, Jovens e Adultos (EAJA) 2010-2014 da SME de Goiânia apresenta a estrutura organizacional do Programa AJA-Expansão expondo que essa organização se dá em função de garantir formação integral e cidadania aos educandos, mas sem explicações acerca do que seja uma educação integral, ou de como essa cidadania pode ser garantida. Ou seja, sem nenhuma discussão acerca desses e de outros aspectos que estão na base do AJA-Expansão. Essa falta de explicitação acerca do trabalho pedagógico com o AJA-Expansão pode ser entendida também como uma expressão da falta de atenção a esse Programa, parece indicar não estar havendo um repensar da sua proposta, ficando subsumido na proposta geral da EAJA da SME.

Além de aparecer na Proposta Político Pedagógica da EAJA da SME de Goiânia, o Programa AJA-Expansão tem um projeto específico para a consolidação da parceria com o PBA. Entendo, porém, que, pela relevância desse Programa, para valorizá-lo e enriquecer o trabalho junto com os grupos dos educadores populares, é necessário que seu projeto seja partilhado, que sua proposta seja apresentada integralmente, com detalhamentos, explicitações, avaliações e discussões. As experiências boas, as trocas, as sugestões para um trabalho contínuo, enriquecido com as experiências de cada ano a fim de que possa se aproximar cada vez mais das comunidades atendidas, se revendo, se recontextualizando e se aprimorando. Assim, poderá compartilhar e discutir a compreensão do que seja uma educação integral, pensar em uma transversalização da EA, num trabalho mais profundo e de continuidade. Em depoimento para esta pesquisa, a coordenadora popular que acompanhava a minha turma disse não saber que existe uma proposta de EAJA na SME e que, também, não 
conhecia nenhum projeto específico do AJA-Expansão. Um forte indício de desatenção. O Programa AJA-expansão aparece inserido na Proposta da EAJA da SME, apenas na parte concernente à "Estrutura organizacional", e apresentado da seguinte forma:

\subsection{Estrutura organizacional}

Tendo como foco o atendimento às necessidades, anseios e especificidades dos educandos, a EAJA está organizada de forma a garantir sua formação integral e seu pleno direito de exercício da cidadania.

\subsubsection{Programa AJA-Expansão / Brasil Alfabetizado}

- Carga horária: 360 horas anuais e 10 horas semanais.

- Jornada letiva: $2 \mathrm{~h} 30 \mathrm{~min}$ diárias.

- Números de educandos por turma: mínimo de 15 e máximo de 25.

- Desenvolvimento de leitura e escrita contextualizada e pensamento lógico-matemático.

- Registro de avaliação: produção textual mensal.

- Desenvolvimento em locais alternativos, tais como empresas, sindicatos, igrejas, associações e outras instituições.

- Formação inicial com duração de 40 horas/aula.

- Formação continuada: encontros semanais organizados em grupos que funcionam nos turnos matutino e noturno.

- Acompanhamento mensal do coordenador aos respectivos grupos.

- Uma reunião semanal da coordenação, para reflexão e planejamento.

- Financiamento para participação em seminários, encontros e congressos. (GOIÂNIA, 2013, p. 48-49)

O cumprimento de toda essa "Estrutura Organizacional" foi efetivado dentro dos limites entre o proposto e as possibilidades de realização, durante a experiência vivida no ano de 2014 com a alfabetização dos catadores. Assim, apresento essa "Estrutura Organizacional" do AJA-Expansão aplicada na experiência vivida na comunidade de catadores, explicitando como cada item se efetivou.

Carga horária: nessa experiência, a carga horária das 360 horas foi cumprida, priorizando o atendimento aos educandos. Por ter iniciado as atividades na turma somente no dia 12 do mês de maio, não foi feito intervalo de férias no mês de julho e as atividades se sucederam ininterruptamente até o dia 16 do mês de dezembro.

Jornada letiva: a jornada de $2 \mathrm{~h} 30 \mathrm{~min}$ diárias foi cumprida seguindo uma combinação com os educandos. Essa combinação consistiu no cumprimento de $2 \mathrm{~h}$ de atividades diárias no grupo, complementada com atividades para serem feitas fora da sala, em outros horários de cada um. Dessa maneira, as atividades em sala aconteciam das 17h30min às 19h30min. Essa 
sugestão precisou ser acatada por solicitação do grupo, sob pena de os educandos não permanecerem na turma. As atividades propostas a serem realizadas fora desse horário consistiam muito em observação da natureza, apreciação da lua cheia, contemplação das estrelas, observação e cuidados com a água, plantação de horta, cultivo de flores, respiração profunda, observação dos sentimentos ao longo do dia, atividade de escrita do próprio nome e de palavras do mundo, dentre outras. Essas atividades eram retomadas no início de cada encontro, frequentemente em clima de risadas e descontração.

Número de educandos na turma: esse foi o item mais difícil para ser cumprido. A turma inicialmente foi cadastrada em dois grupos, sendo 8 educandos na cooperativa Coocamare e 8 na cooperativa Acop. Na segunda semana de atendimento o grupo da Coocamare se desfez, com uma greve na coleta seletiva os alunos não compareceram. As atividades se concentraram somente na turma da Acop. As atividades realizadas inicialmente no galpão da cooperativa chamava a atenção de quem por ali passava e várias pessoas da comunidade se cadastraram, formando uma lista de 15 educandos. As dificuldades de cada um para vencer as resistências nutriam a irregularidade do grupo. Em alguns dias compareciam 3 alunos, em outros 6 compareciam, às vezes a presença era de apenas 2 educandos, mas todos os dias teve frequência. E as atividades eram desenvolvidas com o mesmo entusiasmo, valorizando a presença do aluno que estava ali.

\section{Desenvolvimento da leitura e escrita contextualizada e pensamento lógico-} matemático: foi um item desafiador para todo o grupo e, especialmente, para mim. Como desenvolver essa atividade, como introduzir o procedimento da leitura, com qual lógica caminhar? Do analítico para o sintético, do sintético ao analítico, do global para o silábico, das letras às palavras, das palavras ao mundo e do mundo às ideias. Os princípios do método desenvolvido por Paulo Freire foram a estrela guia e, me orientando por esse caminho, fomos plantando flores, somando com as estrelas do céu, subtraindo dores, juntando poesia com alegria, para desabrochar pensamentos e palavras.

Registro de avaliação: foi um procedimento que fizemos por meio de rodas de conversa, que foram gravadas como registro avaliativo feito pelo próprio grupo. O desenvolvimento das habilidades de leitura, escrita e do pensamento lógico matemático foi avaliado pelos teste de entrada e teste de saída. O teste de entrada avalia os conhecimentos com os quais os educandos iniciam a formação, o teste de saída é outra avaliação feita ao final da formação. Esses testes são enviados pelo Programa Brasil Alfabetizado (PBA) para avaliação das aprendizagens dos alunos. Acompanhando esses testes vem um guia com orientações para a aplicação e para o preenchimento das fichas de registro dos resultados 
obtidos. Por ter sido a minha primeira experiência com essa formação, fiquei surpresa ao saber que teria de aplicar esses testes. A nossa programação teve de ser refeita e as atividades adaptadas em função dessa exigência. Todos os educandos tinham de fazer os testes. Isto exigiu que nos desdobrássemos para o cumprimento dessa atividade, porque a frequência dos educandos sempre foi muito irregular e, em decorrência, enquanto um grupo finalizava os testes, outro iniciava. Tive receio de que pudesse ter estranhamento e rejeição por parte dos educandos, mas acho que isso foi maior somente em mim, pois recebi esses testes como sendo uma quebra do trabalho que estávamos fazendo e, de fato, foi. Algumas estratégias foram suspensas, como a oficina de produção de papel reciclado e os trabalhos com vidros. Mas os educandos foram se envolvendo com os desafios trazidos e gostaram da experiência com os testes.

Desenvolvimento em locais alternativos: esse item, relativo ao local onde as atividades devem ser desenvolvidas, foi outro desafio a ser superado. A comunidade não tinha um espaço onde a turma pudesse ser instalada, por isso a formação foi iniciada provisoriamente no próprio galpão da cooperativa. Estava acontecendo uma greve dos trabalhadores da coleta seletiva na cidade e, com a redução do material, pudemos utilizar esse espaço. Durante o mês de junho ficamos na varanda da casa de uma catadora e no início do mês de julho fomos para uma sala alugada para instalar a turma. O pagamento do aluguel foi assumido com a bolsa do educador popular. Esse foi o lugar alternativo onde a formação foi realizada durante todo o restante do período. Naquela região não havia empresa, sindicato, igreja, associação ou outro tipo de instituição para essa parceria, mesmo assim, da experiência empreendida percebi que o local deve ser escolhido a partir das relações estabelecidas na comunidade onde a turma será instalada.

O local de funcionamento da turma precisa ser agregador de todos indistintamente. Assim, se for na residência de alguém pode afastar aqueles que não tenham boa relação com as pessoas daquela residência, se for em uma igreja, pode afastar quem não é daquela religião. O espaço do galpão da cooperativa, onde iniciei a experiência, teve maior aceitação da comunidade, mas não tinha a condição para o funcionamento da turma. Ao irmos para a casa da catadora, houve a desistência de um aluno por razões de relações interpessoais. A sala alugada foi um espaço que se institucionalizou, criado somente para esse fim e aberto a todos indistintamente.

Formação inicial com duração de 40 horas/aula: essa formação é realizada com os educadores populares, ao longo das duas primeiras semanas de atividade. Para essa formação são convidados professores da Universidade Federal de Goiás, técnicos ou outros 
profissionais de acordo com a programação realizada. Não me foi possível participar dessa formação, pois o deferimento ao meu processo junto à SME para a realização da pesquisa foi expedido somente após esse momento, quando pude cadastrar a turma junto ao Programa e, consequentemente, a mim como educadora popular.

Formação continuada: essa formação é direcionada aos educadores populares e no ano de 2014 se deu somente no turno noturno, embora tivessem turmas atendendo no matutino e no vespertino, mas todos os educadores populares puderam se reunir nesse turno. Foram encontros semanais realizados sempre na $6^{\mathrm{a}}$ feira, das $19 \mathrm{~h}$ às $21 \mathrm{~h}$. Esses encontros foram momentos fecundos e da maior importância para a alimentação e fortalecimento do trabalho. Muitas trocas, muita partilha, águas aquecidas no encontro de vidas. A equipe coordenadora, responsável pela formação, era composta por uma chefe da coordenação e mais duas coordenadoras, as que faziam o acompanhamento das turmas. Com relação à EA, a chefe da coordenação possuía uma formação na área da biologia que lhe fazia colocar os pés na EA. Uma pessoa sensível, amorosa e muito comprometida em trabalhar com elementos da natureza. Buscou desenvolver uma formação integrada com a natureza, para isso trouxe um rico material sobre o cerrado com vídeos e textos. Também apresentou um material lúdico muito rico, criado por ela, para trabalhar com a apresentação dos animais e plantas do cerrado.

Essa mesma coordenadora fez uma formação muito especial junto aos educadores populares sobre o plantio da horta, acoplado com o "Projeto Horta em Pequenos Espaços" que já existe na SME, ensinando e estimulando como fazer, como plantar. Houve uma formação prática, em um terreno da SME, com o técnico do Projeto. Essa formação gerou frutos no trabalho das turmas e também em meu trabalho no grupo de catadores, uma importante iniciativa dessa coordenadora, fazendo uma rica abordagem da EA. O que pude observar com relação a esse trabalho é que a abordagem da EA se aproximou a um tema, algo como um conteúdo a mais sendo trabalhado, um movimento externo. A EA necessita ser trabalhada a partir do próprio ser, a partir da sensibilização, do trabalho corporal, da respiração, da integração das partes, do movimento em espiral, num movimento dialético e sistêmico de dentro para fora, unindo e integrando a parte ao todo e o todo à parte para que o educando possa dialogar em um ambiente formador.

Para que haja melhor compreensão do trabalho com a EA, é necessário formação. Essa é uma formação que precisa ser feita no universo da formação inicial e continuada, porque trabalhar com a EA não é fazer dela mais um conteúdo, mas para que essa mudança seja feita é preciso que seja compreendida e essa compreensão se faz em uma formação que seja integradora. Dessa maneira, todo esse trabalho desenvolvido tangenciou a transversalização, 
sem romper com o caráter disciplinar, conteudista, pois trabalhar com a EA é, antes de tudo, nos percebermos seres pertencentes à natureza, em permanente troca na sustentação da vida e esse envolvimento não foi feito. Daí a importância da formação abrindo passagens para percorrer os caminhos de dentro, integrando a nossa vida, em suas múltiplas dimensões, do micro ao macro, às outras vidas do planeta. Dessa maneira, podemos vislumbrar uma EA transversalizada.

Figura 9 - Equipe do AJA-Expansão e educadoras populares.

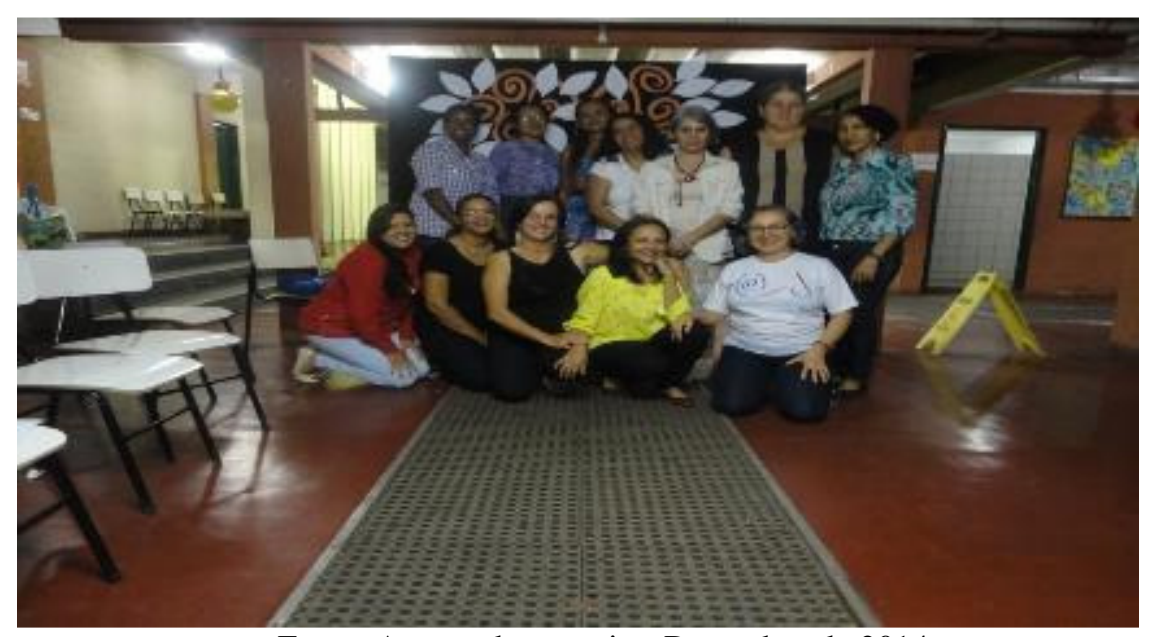

Fonte: Acervo da pesquisa. Dezembro de 2014.

Acompanhamento mensal do coordenador: Na equipe de coordenação havia uma coordenadora que fazia o acompanhamento da nossa turma. A cada visita mensal ela fazia uma produção textual descritiva e avaliativa. Nem sempre sabíamos quando ela compareceria. Em uma das primeiras visitas feitas, eu não estava na turma. Às vezes eu precisava viajar para ir à UnB, em Brasília, sempre deixando atividades com a monitora que me acompanhava. $\mathrm{O}$ grupo estranhou a presença da coordenadora e o estilo da aula. Disse que ela era brava. Essa imagem logo foi desfeita, em outras ocasiões, quando pudemos intermediar interlocuções amorosas com essa coordenadora. Notava que ela era uma educadora alfabetizadora experiente, habilidosa e que rapidamente transformava as conversas em palavras para serem escritas. Aprendemos muito com ela.

Reunião semanal da coordenação: essa era uma atividade interna da equipe coordenadora para reflexão e planejamento. Tratava-se de uma reunião preparatória onde as coordenadoras avaliavam, planejavam, elaboravam materiais, pesquisavam. Ao longo do ano, fomos percebendo o quanto a equipe coordenadora trabalhava sozinha no acompanhamento do AJA-Expansão. As atividades desenvolvidas eram de sua própria iniciativa. Havia muita limitação para realizar visitas, promover excursões com o grupo ou liberação de materiais solicitados. Para equipar a sala do meu grupo a equipe coordenadora fez a solicitação, mas 
não conseguiu as carteiras e nem um quadro de giz. Eu equipei a sala com a colaboração de uma catadora e com o que eu levei de mesa e banquinhos. O quadro de giz foi feito em pintura na parede.

Financiamento para participação em seminários, encontros e congressos: esse financiamento foi utilizado ao longo do ano. O Programa AJA-Expansão é afiliado da Rede Mova Brasil de alfabetização de adultos. O MOVA - Movimento de Alfabetização de jovens e Adultos, foi criado por Paulo Freire quando foi secretário de educação em São Paulo, durante a gestão da prefeita Erundina, de 1989 a 1992. Em 2014, de 31/10 a 02/11, foi realizado o $10^{\circ}$ Encontro Nacional da Rede Mova-Brasil, em Porto Alegre, RS. A estadia e alimentação para todos os delegados foi financiada pelo MEC e as passagens, em número limitado, foram subsidiadas com financiamento próprio para o AJA-Expansão. Eu participei como delegada financiando a minha passagem, mas o financiamento recebido pelo Programa foi muito importante por ter proporcionado a participação de uma educadora popular de nosso grupo em uma experiência inédita e emocionante para ela e de grande contribuição para todo o grupo.

O encerramento das atividades do Programa AJA-Expansão, nos primeiros anos das formações, era um momento cerimonioso, festivo e de grande alarido na SME. As autoridades da cidade participavam, era feita a entrega de certificados em momento solene, em grandes auditórios. Não faltavam discursos, entusiasmos, emoções, prantos e sorrisos. Os educandos eram chamados ao palco um a um para receber o certificado. Em 2014, ao final da formação dos grupos, os educandos do meu grupo já estavam esperando a cerimônia. Eles estavam se sentindo orgulhosos, envaidecidos e felizes por se verem pertencentes a uma rede de educação. O pertencimento se fortalecendo nesse caminho. Já havíamos conversado sobre isso e eles sabiam dos vínculos institucionais que a turma possuía e se viam, satisfeitos, alunos da RME de Goiânia. Mas naquele ano não teve nenhuma cerimônia, a DEF-AJA não fez a certificação, a SME não prestou nenhuma homenagem.

A falta dessa cerimônia foi substituída pela grandiosa celebração feita pelo nosso próprio grupo, em nosso espaço, com a participação aberta da comunidade. Ali celebramos com alegria, emoção e festa. Fizemos um convite que foi encaminhado para a SME, para a Incubadora Social da UFG, para o CMV, na FE/UFG, para a cooperativa Acop e a toda comunidade onde a sala se localizava. Fizemos a nossa própria cerimônia com entrega dos certificados. Não faltaram autoridades: contamos com a presença da coordenadora chefe do Programa AJA-Expansão, da coordenadora que nos acompanhou, da professora de artes da UFG que nos deu um grande apoio, de sua aluna orientanda que foi grande parceira nas 
atividades da turma e de uma professora da FE/UFG, que faz assessoria ao trabalho da EAJA e é membro da equipe de elaboração do AJA-Expansão.

Fizemos a entrega dos certificados aos alunos e essa professora da FE/UFG explicou à turma que os certificados eram provisórios, por estarem sem assinatura, mas que ainda receberiam os certificados assinados. A falta de assinatura das autoridades da SME se deu por não haver formulários de certificados feitos para aquele ano. Como havia muita sobra de certificados de um ano anterior, eu fiz à mão a atualização do ano e pedi que a autoridade da DEF-AJA os assinasse. A correção feita não foi aceita e se dispuseram a fazer outros certificados sem rasuras. O nosso encerramento estava marcado para daí a dois dias. Sabendo que não ia dar tempo, depois de ponderar, decidi por fazer a entrega provisória sem nenhuma assinatura, por não poder esperar por outro, já que não havia nesses certificados espaço para a assinatura dos coordenadores e dos educadores populares. Isso não tirou a alegria, nem a emoção, nem o brilho da festa de nosso encerramento. A sala cheia nos dizia que a conquista estava feita e o espaço pequeno para abrigar tantos desejos e sonhos despertados.

Figura 10 - Águas da celebração

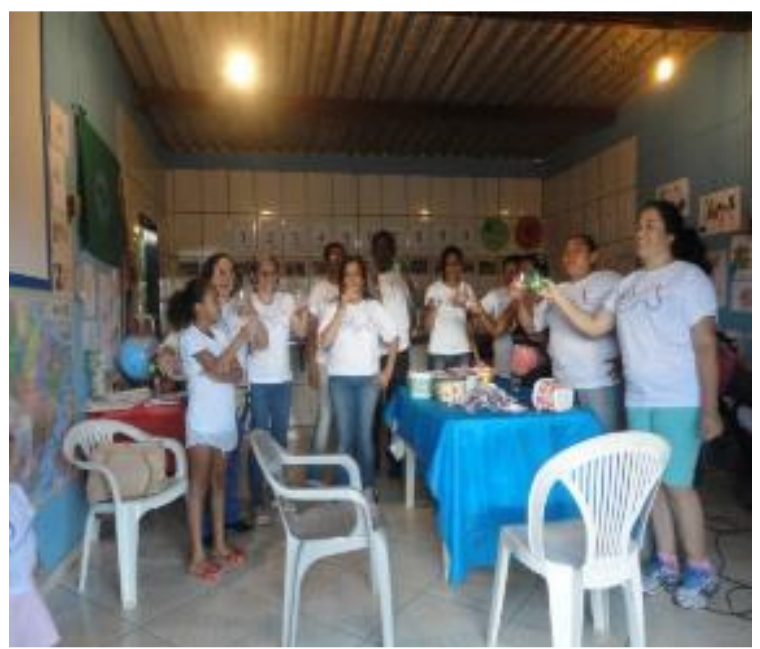

Figura 11 - Fechando a roda

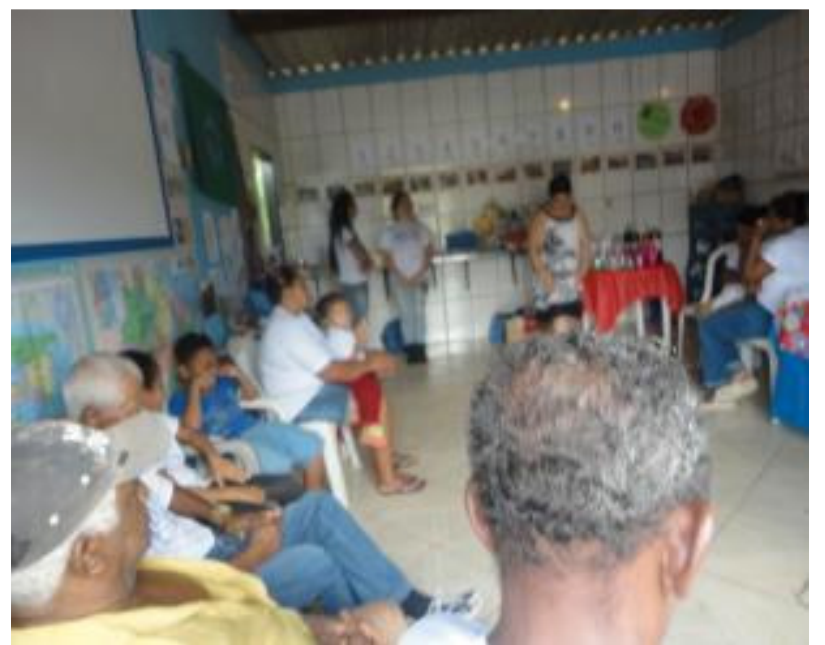

Fonte: Acervo da pesquisa. Dezembro de 2014. 
Figura 12 - Entrega de certificado I
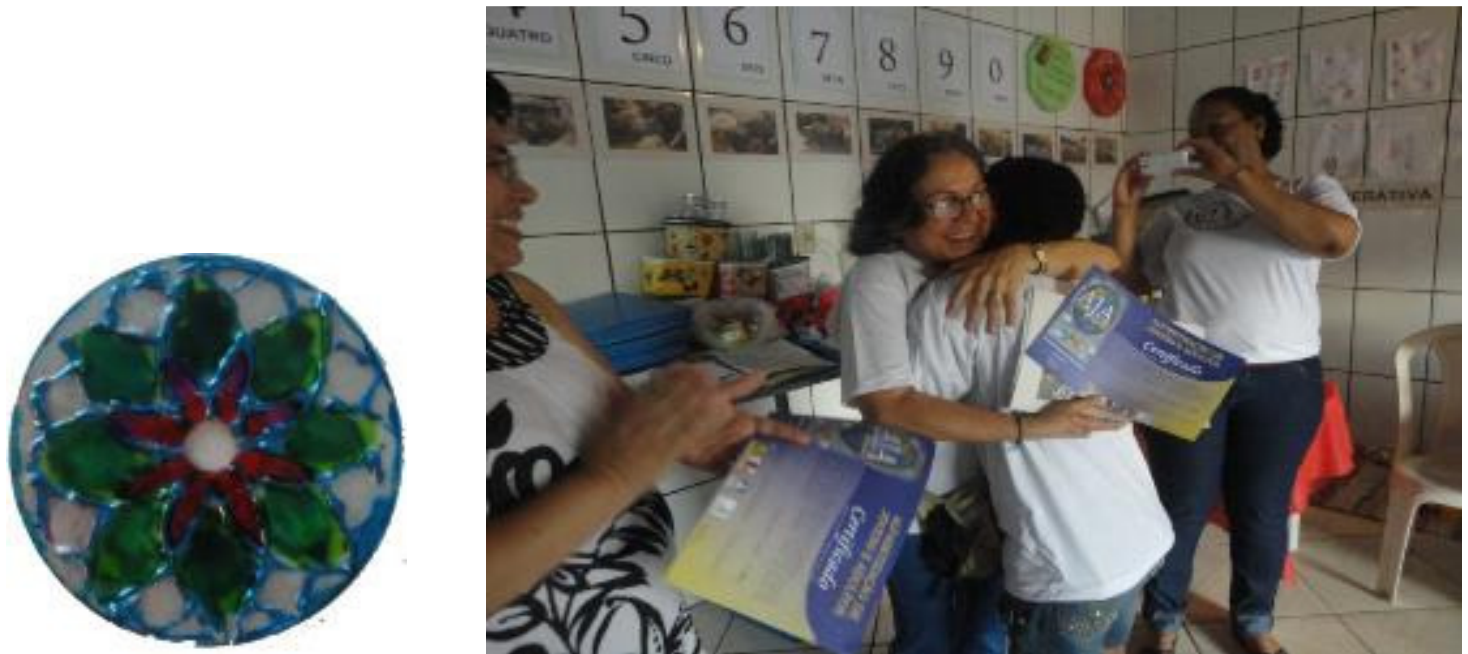

Fonte: Acervo da pesquisa. Dezembro de 2014.

Figura 13 - Entrega de certificado II

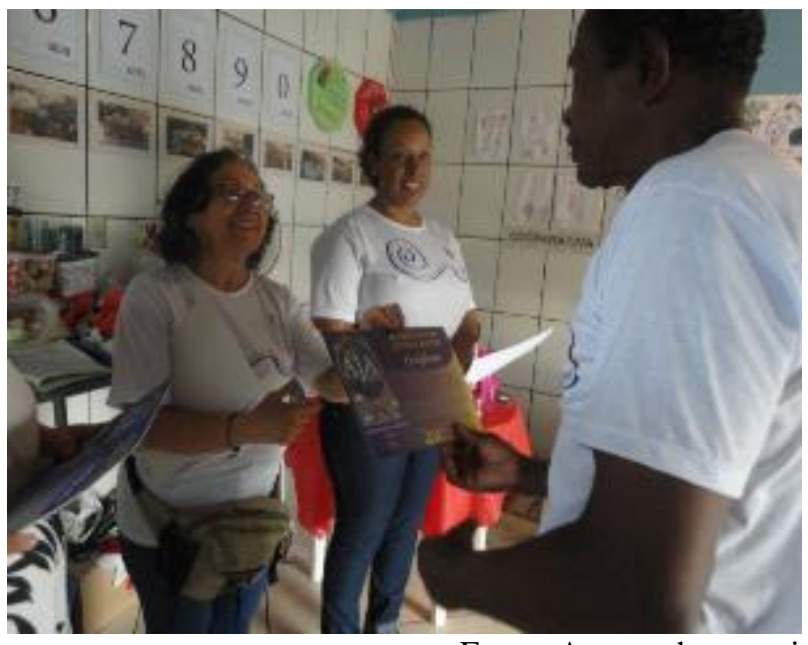

Fonte: Acervo da pesquisa. Dezembro de 2014.

Figura 14 - Entrega de certificado III

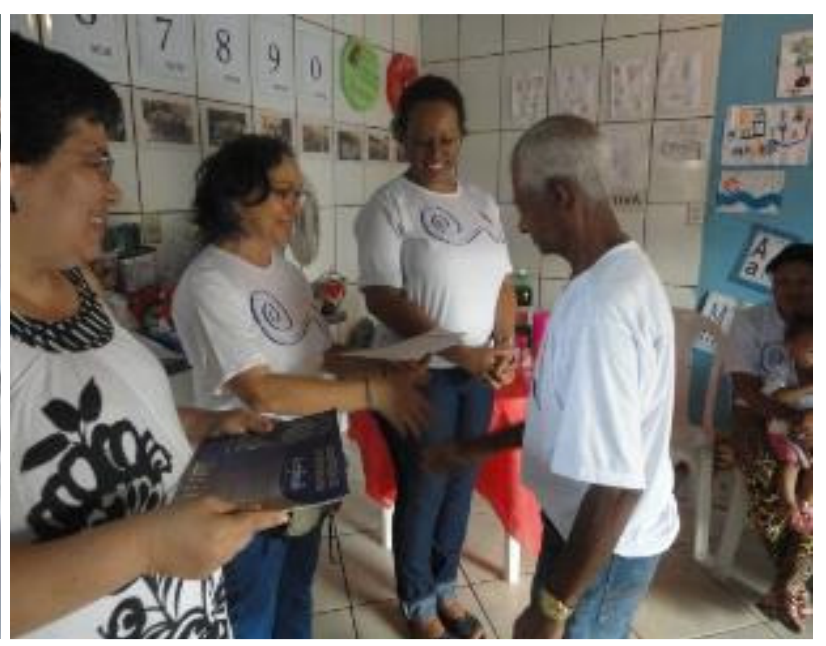

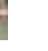

Figura 15 - Entrega de certificado IV
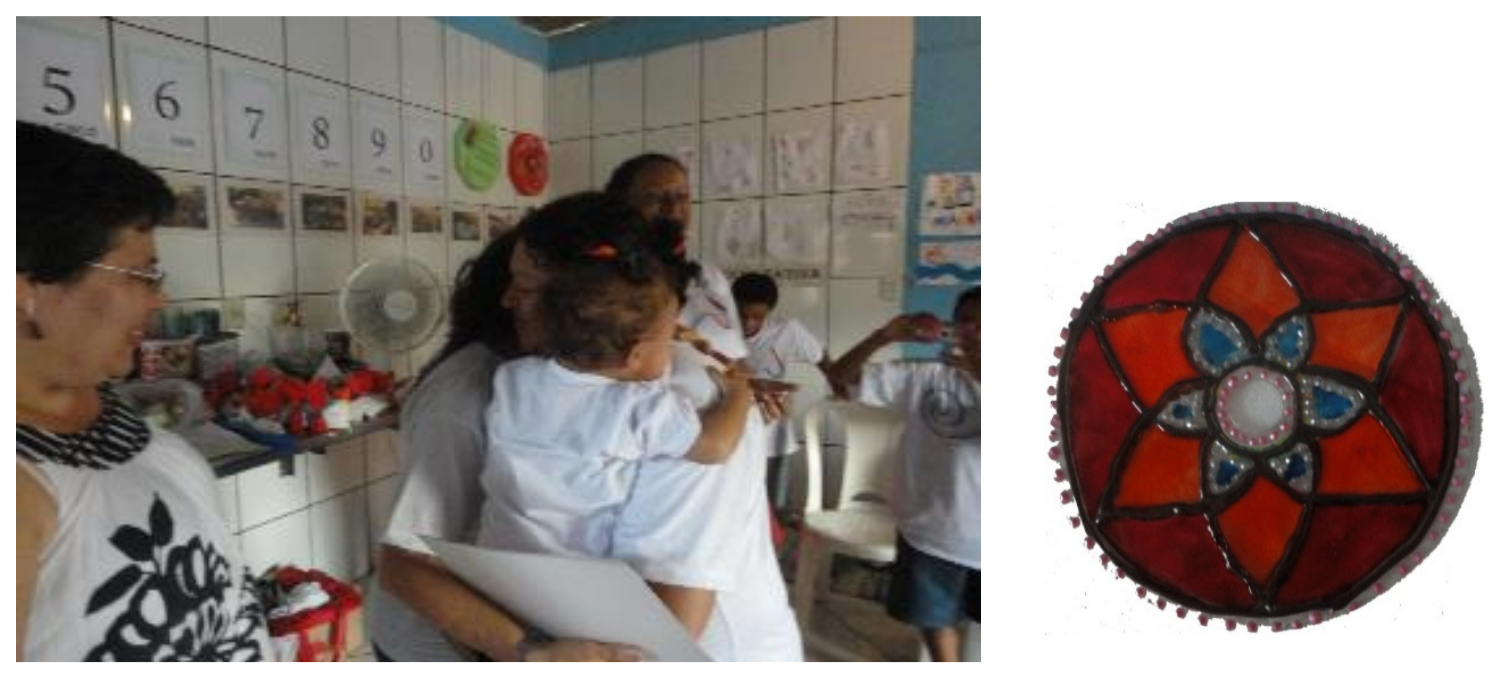

Fonte: Acervo da pesquisa. Dezembro de 2014. 


\section{CAPÍTULO 3}

A metodologia do contorno das águas e a definição do leito

Figura 16 - Caminho das águas

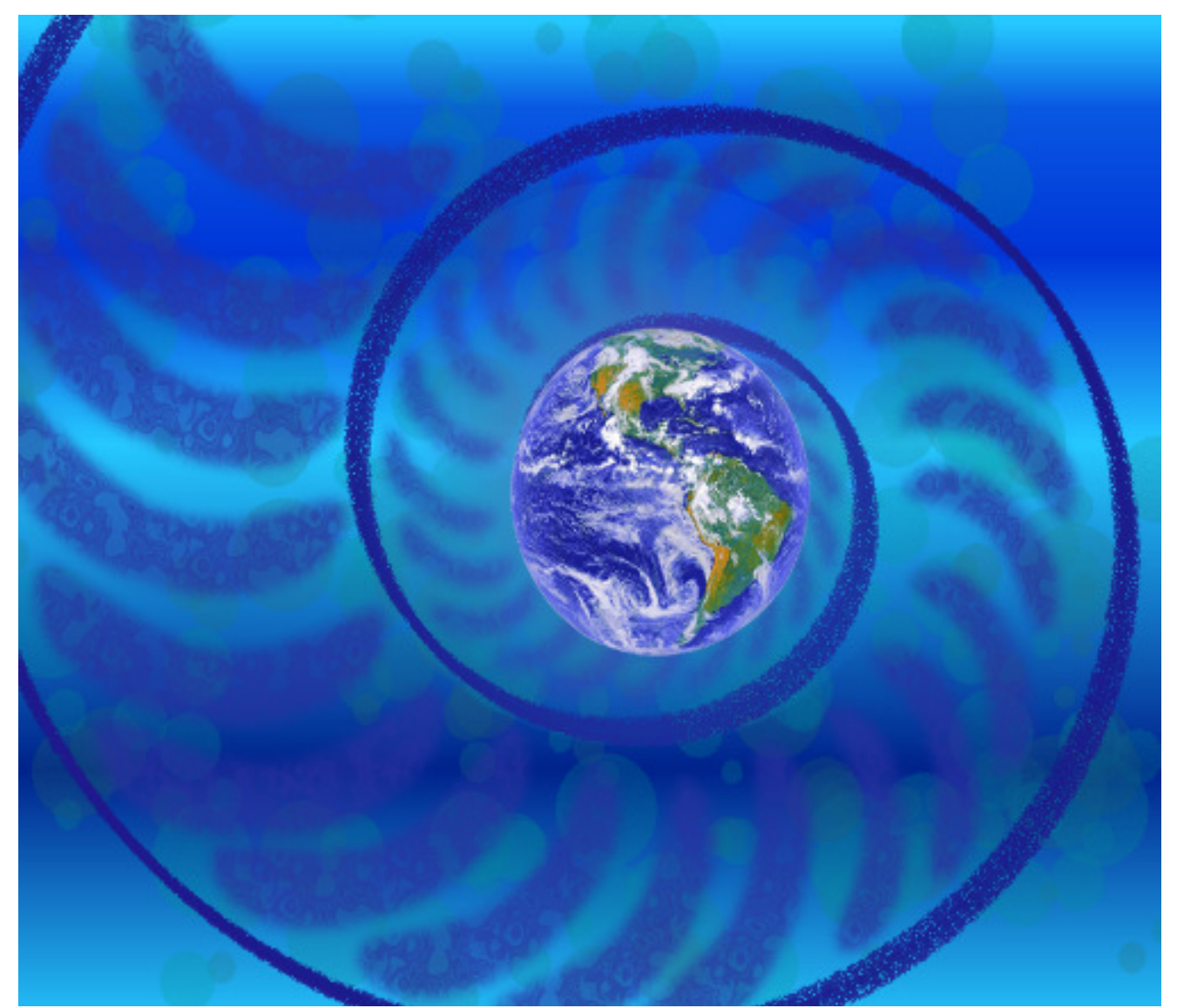

Fonte: Fotomontagem de Virgílio de Castro Neves. Ano: 2014. 


\title{
CAPÍTULO 3 - A METODOLOGIA DO CONTORNO DAS ÁGUAS E A DEFINIÇÃO DO LEITO
}

\author{
Acho que do mesmo jeito que a gente trabalhou (...), \\ que foi com aula de artes, tudo bem misturado, \\ com passeios, porque vai abrindo. \\ Até porque os catadores já têm uma certa idade avançada, \\ então pra eles, aprender mais, só vendo mesmo. \\ Tem coisa que eles vão aprender vendo, sabendo (...). \\ Naná
}

\subsection{Introdução das águas que formam o leito que se apresenta}

O diálogo entre a EA e a EP, trazido pela natureza desta pesquisa, requer a necessidade de procedimentos metodológicos que alcancem essa articulação. Assim, foi feita inicialmente a opção pela pesquisa-ação, pela correspondência ao pensamento em que se assenta a EA. As águas movimentadas ao longo do percurso foram me revelando que esse diálogo se efetivaria de maneira mais integradora e aprofundada fazendo ainda a fusão com a Pesquisa Participante, que se alinha à história da EP. Assim, fui me colocando em uma postura de abertura para a construção de todo o diálogo possível entre esses campos, a fim de enriquecer essa articulação e fortalecer a intenção de apresentar uma experiência capaz de apontar para resultados significativos no universo da alfabetização de adultos.

É pertinente que se façam alguns comentários acerca do que se compreende por alfabetização, pois ao longo dos anos esse conceito vem se modificando. Segundo Soares (2005), durante algumas décadas, os Censos Demográficos definiam como alfabetizados apenas saber ler e escrever, mas aos poucos essa definição foi se tornando insuficiente, pois foram surgindo novas e diversificadas demandas sociais e profissionais exigindo o uso competente da leitura e da escrita. Desse novo contexto nascem ressignificações do conceito de alfabetização, surgindo termos como: letramento, alfabetismo funcional, analfabeto funcional. Soares (2005. p. 93) explica que

É essa ampliação do conceito - essa ressignificação do conceito - que trouxe também a palavra letramento, usada com aproximadamente o mesmo sentido de alfabetismo funcional. Em todos esses novos termos - alfabetização funcional, alfabetizado funcional, analfabeto funcional, alfabetismo funcional, letramento - está presente o conceito de que a inserção no mundo da escrita se dá através de dois processos: a aprendizagem do sistema de escrita (o sistema alfabético e o sistema ortográfico) - o que se poderia denominar alfabetização, em sentido restrito - e o desenvolvimento de competências (habilidades, conhecimentos, atitudes) de uso efetivo desse sistema em práticas sociais que envolvem a língua escrita - a alfabetização (ou alfabetismo) funcional, o letramento. 
O que se depreende dessas transformações é que a alfabetização hoje não pode mais ser abordada separada da educação em geral. A inserção ao mundo da escrita requer a sua continuidade, pois o desenvolvimento de capacidades, noções de mundo e maneiras de agir exigem a ampliação da leitura e, mais que isso, enseja a busca de sentidos. Essa noção de alfabetização vai se juntar ao mesmo entendimento de que a leitura do mundo precede a leitura da palavra da escrita.

A turma constituída para a realização da pesquisa foi vinculada ao Programa AJAExpansão da SME de Goiânia. Por essa razão, ao permear as margens desse percurso o faço a partir do referencial trazido pelo Programa AJA-Expansão da SME de Goiânia, pois esse foi o referencial com o qual a pesquisa precisou dialogar ao trazê-lo para o campo da EA. O AJAExpansão é uma das ações dessa secretaria voltadas para a educação de jovens e adultos. Por essa razão, aparece como parte da Proposta Político-Pedagógica da EAJA ${ }^{12}$ da SME de Goiânia, que em sua versão 2010-2013 aponta com qual concepção de educação ela se compromete. Dessa forma, inicia a sua “Apresentação" expondo:

\begin{abstract}
A Proposta Político-Pedagógica (PPP) da Educação de Adolescentes, Jovens e Adultos (EAJA) apresenta uma organização curricular fundamentada na concepção humanista e histórico-dialética de formação do sujeito, na compreensão da prática pedagógica como uma atitude política e dialógica que visa a construção do conhecimento e cria possibilidades de interferência do sujeito na sociedade.
\end{abstract}

Essa concepção faz referência a Paulo Freire que teve no exercício da alfabetização de adultos o lugar de origem de seu projeto educacional, assentado em uma concepção comprometida com uma perspectiva de educação onde se pode pensar uma prática pedagógica "humanista", "política" e "dialógica". "O diálogo é este encontro dos homens, mediatizados pelo mundo, para pronunciá-lo, não se esgotando, portanto na relação eu-tu." (FREIRE, 1987, p. 78)

Com o compromisso de desenvolver uma educação sob essa concepção apresentada, a EAJA da RME de Goiânia adota um referencial teórico sustentado por autores que vão amparar a concepção assumida, na estruturação e orientação das práticas desenvolvidas, dentre eles: Freire (1987, 2009), Moreira e Candau (2007), Vygotsky (1998), Oliveira (1999),

\footnotetext{
${ }^{12}$ EAJA é a nomenclatura adotada pela Divisão do Ensino Noturno da SME de Goiânia para todo o Ensino Fundamental direcionado à Educação de Adolescentes, Jovens e Adultos a partir da Gestão de 1997-2000. Cabe esclarecer que a referência ao adolescente se inicia a partir de uma experiência intitulada: "Intenção de estudos: experiência com adolescentes de $1^{\mathrm{a}}$ à $4^{\mathrm{a}}$ série de 11 a 17 anos" realizada em 1992, com turmas de adolescentes, na Faculdade de Educação da Universidade Federal de Goiás (FE/UFG).
} 
Oliveira e Paiva (2004), entre outros. A leitura desses autores apresenta como pressupostos básicos a consideração do ser humano como sujeito historicamente constituído, a compreensão da realidade como processo que se configura em face da intervenção desses sujeitos, e os espaços de escolarização como locus que podem contribuir na formação humana dos sujeitos que deles participam.

A concepção apresentada vincula-se ao pensamento histórico dialético, que nos remete a Marx. A esse respeito, há que se considerar a relevância da contribuição do pensamento desse autor, acrescentando ainda que "nenhuma análise textual pode substituir as poderosas ferramentas de análise da sociedade de classes que nos foram legadas pela economia política marxista" (SILVA. 2003, p. 147), mas o objeto desta investigação requer outras abordagens provenientes de uma epistemologia transdisciplinar suscitada pela Educação Ambiental. Essas novas abordagens suscitadas pela EA também se inserem em um movimento dialético, mas envolvendo o todo e as partes em relações sistêmicas permanentemente interconectadas afastando-se das posturas fragmentadoras, nesse sentido, buscando uma visão de totalidade capaz de trazer novas relações, além da já estabelecida relação entre o todo e as partes. Partilho esse entendimento com Catalão (1993, p. 17) quando esclarece que

A concepção de totalidade aqui trabalhada incluiu a necessidade de
estabelecer possíveis diálogos, além daquele fundamental entre o todo e as
partes, outros tantos que superassem a cisão entre sincronia/diacronia,
homem/natureza, sujeito/objeto, indivíduo/sociedade, razão/sentimento,
conhecimento/sabedoria, mente/corpo, síntese/análise, mundo vivido/mundo
concebido e outros tantos pares de opostos que somente uma metodologia
dialética poderia nos abrir caminho diante da inesgotabilidade do real.

Tomando o aspecto didático-pedagógico como caminho para este estudo, participei de uma ação de alfabetização de adultos, com intervenções no processo, agregando uma postura transdisciplinar a essa proposta apresentada pela SME de Goiânia, colocando-a sob o enfoque da Educação Ambiental. Para isso, há que se considerar o entrecruzar da tomada de consciência ecológica na relação com as políticas públicas e com a formação dos educandos e educadores. Ao mesmo tempo, há que se incluir uma abordagem a partir dos elementos que constituem essa opção tomada: a linguagem, o currículo, a avaliação, mas inseridos em uma postura transversal (BARBIER, 1997) necessária para a Educação Ambiental na produção do conhecimento.

A Educação Ambiental surge da percepção das ameaças de grandes proporções impostas ao planeta. As observações apontam que a maneira como o homem vem se relacionando com a natureza, tomando-a devastadoramente apenas como fonte de exploração 
para o suprimento de seus interesses, se tornou um prenúncio de destruição da própria vida. A EA, portanto, entende que é preciso que a humanidade repense o seu percurso e busque outras maneiras de se relacionar com a natureza, de se relacionar com a vida. As implicações dessas buscas são complexas, mas se iniciam na tomada de consciência de cada indivíduo na relação com o outro e com a sociedade, no cuidar de si, do outro e do planeta. Uma experiência, portanto, de alfabetização de adultos de cooperativas de catadores de resíduos sólidos, com foco na Educação Ambiental, é uma tentativa de trilhar outros caminhos, é um esforço de ruptura com um modelo cartesiano comprometido com os interesses do grande capital e responsável pela crise profunda por que passa a humanidade.

Deste modo, a transversalidade apresentada por Barbier, se entrelaça à noção de transdisciplinaridade (NICOLESCU, 1999, p.180) e à teoria da complexidade trazida por Morin. Essas noções constituem uma postura indispensável para desvelar as relações da multirreferencialidade do conhecimento, valorizando o papel da sensibilidade, da imaginação, da emoção, da intuição, da poesia, da metáfora imprescindíveis para a religação do sujeito à sua natureza e à natureza da natureza. (MORIN, 2008)

Barbier (2007) fortalece o meu entendimento a esse respeito, dando-me segurança na escolha pela pesquisa-ação existencial ao longo de suas explanações, mas especialmente quando explica que:

Desse ponto de vista, as pesquisas-ações que eu empreendo tratam, há anos, de temas muito enraizados na afetividade humana (nascimento, amor e paixão, velhice, morte, sofrimento, autoformação, vida social alternativa, interculturalidade, etc.). Faz parte da natureza da pesquisa-ação assim como da natureza das artes marciais que a obsessão do rigor e da competição desapareça, ao longo da experiência, em prol de sua finalidade repleta de uma complexidade crescente do Potencial Humano. (BARBIER, 2007, p. 67)

A pesquisa-ação existencial me faz perceber, por conseguinte, que, para este estudo, é necessária uma compreensão capaz de demonstrar a relação existente entre os elementos fundantes da pesquisa: a Educação Ambiental, a Educação Popular, as cooperativas de resíduos sólidos e os sujeitos envolvidos nessa tessitura. Encontro em Morin esse entendimento quando apresenta a complexidade como a conexão entre a unidade e a multiplicidade, ressignificando o conhecimento pertinente.

O conhecimento pertinente deve enfrentar a complexidade. Complexus significa o que foi tecido junto; de fato, há complexidade quando elementos diferentes são inseparáveis constitutivos do todo (como o econômico, o 
político, o sociológico, o psicológico, o afetivo, o mitológico), e há um tecido interdependente, interativo e inter-retroativo entre o objeto de conhecimento e seu contexto, as partes e o todo, o todo e as partes, as partes entre si. Por isso, a complexidade é a união entre a unidade e a multiplicidade. Os desenvolvimentos próprios a nossa era planetária nos confrontam cada vez mais e de maneira cada vez mais inelutável com os desafios da complexidade. (MORIN, 2003, p. 38)

Outros aspectos relevantes da formação humana, notadamente quando se trata da alfabetização de adultos, são a linguagem, o currículo e o conhecimento. Ao ler a proposta da SME, Goiânia (2010), percebi que essa equipe tem consciência da importância da concepção de linguagem, currículo e conhecimento tomados por parte de quem orienta o processo ensino-aprendizagem. Assim, essa proposta considera a linguagem

como um processo de interação e comunicação entre o indivíduo e o meio ou entre dois ou mais indivíduos. Representa o principal elemento do sistema simbólico dos grupos humanos, considerada um avanço na evolução da espécie, pois é por meio dela que o homem adquire formas de lidar com objetos do mundo exterior. (GOIÂNIA, 2010, p. 28-29)

Essa compreensão pode assegurar maior possibilidade de contribuir com o processo de alfabetização do adulto. Ela permite liberdade para a apropriação e a construção de um trabalho mais próximo e a partir da realidade, portanto a liberdade de expressão das ideias do sujeito, como participante do processo de transformação de si e de sua realidade. Acrescentase a essa visão, também, uma compreensão ampliada de linguagem lembrando que ela é formada por um aspecto verbal, a escrita e a fala, e outro não verbal, que compreende desde a linguagem corporal até a simbólica, sendo todas essas expressões fortemente influenciadas tanto pela cultura, quanto pela ideologia sociopolítica e econômica do meio em que se inserem.

$\mathrm{O}$ currículo, assim como a linguagem, precisa adequar-se à realidade dessa modalidade de ensino. Precisa estar próximo das necessidades motivadoras do retorno desse aluno à escola, sem baratear o ensino. Para tanto, ele precisa ser processual, ser entendido como um caminho, como um conjunto de princípios que considerem as vivências, as convivências, as ações e inter-relações, num diálogo permanente entre o popular, o científico e a consciência ambiental. De acordo com Freire,

toda prática educativa demanda a existência de sujeitos, um que, ensinando, aprende, outro que, aprendendo, ensina, daí o seu cunho gnosiológico; a existência de objetos, conteúdos a serem ensinados e aprendidos; envolve o 
uso de métodos, de técnicas, de materiais; implica, em função de seu caráter diretivo, objetivo, sonhos, utopias, ideais. (2009, p. 69 - 70)

Dessa forma, o currículo escolar fundamenta-se na reflexão sobre por que se ensina um determinado conteúdo em detrimento de outro, numa relação dialógica enquanto condição metodológica e de resgate, pela escola, dos saberes populares, articulando-os aos saberes científicos, com ênfase aos ambientais, na busca de desvelar a realidade e construir um novo conhecimento. Concebe-se então o currículo como as várias experiências escolares envolvidas no processo do conhecimento em que homens e mulheres se sintam sujeitos críticos e capazes de interferir na sociedade em que vivem. Sob esse entendimento, o currículo não está dado, ele deve ser construído coletivamente e continuamente a partir da realidade social dos educandos envolvidos no processo. O currículo, portanto, se depreende da vida.

O conhecimento, no entendimento tomado pela equipe da DEF-AJA que elaborou a proposta, é um processo humano, histórico, incessante, de busca de compreensão, de organização, formação de conceitos, de transformação do mundo vivido e sempre provisório. Tal ação humana está atrelada ao desejo de saber, de aprender e de mudança, porque o homem é um ser incompleto em busca do ser mais, ou seja, da sua humanização.

De acordo com Moreira e Candau (2007), o conhecimento é o elemento básico do currículo e o processo de aprendizagem desse conhecimento deve ser constituído na expectativa da compreensão das temáticas socialmente construídas, a fim de serem questionadas e reconstruídas pelos sujeitos envolvidos no processo.

Os procedimentos metodológicos se referem às diferentes maneiras como podemos nos aproximar do objeto de conhecimento. Mas sabemos que essas escolhas não são aleatórias, elas são trazidas pelo referencial teórico que dá sustentação aos princípios e pensamentos que se conectam às intenções e posturas adotadas pelo pesquisador, em função das subjetividades e da natureza do objeto a ser investigado. Pelo percurso escolhido, encontrei pensamentos que foram demarcando as trajetórias, as lutas e os contextos, fazendo nascer, de um movimento contínuo e integrado, a concepção de uma educação ambiental popular.

\section{2 Águas da metodologia na arte de inventar caminhos}

A pesquisa realizada com a alfabetização de adultos trabalhadores de uma cooperativa de resíduos sólidos, foco deste estudo, confirmou a importância dos vínculos entre as opções 
metodológicas, o referencial teórico, o objeto da pesquisa e as ações empreendidas. Algumas escolhas foram feitas a priori, a partir da coerência do sujeito pesquisador entre sua percepção de mundo, de sociedade, de humanidade, suas intencionalidades e suas questões de investigação delineadoras do objeto da pesquisa, que foram se redefinindo na ação. As intencionalidades intrínsecas à pesquisa e, em especial, ao diálogo entre a Educação Ambiental e a Educação Popular se baseiam em um referencial teórico que faz "sua articulação com o real concreto, e uma tentativa de ser compreendida pelos membros de uma comunidade que seguem o mesmo caminho de reflexão e ação". (MINAYO, 1994, p. 19). Essa articulação assinala a necessidade de uma atuação hoje, projetando-se sobre o futuro, pois enquanto a EP nos remete à criticidade transformadora da realidade, a EA parte dessa realidade e a transcende, nos remetendo a mirar horizontes. Vai assim, a partir das trilhas de nossos caminhos de dentro, acoplando-nos ao tempo de renovação da própria natureza, pulsante, silencioso, contínuo e inspirador de confiança na vida, almejando uma educação para o futuro, onde também se localizam os resultados desta intervenção. Sato (2001, p. 2) fala sobre essa perspectiva na EA.

A trajetória traçada para a EA deve mirar adiante, desafiar, estabelecer um horizonte de referência, sempre palpitante, e que pelo próprio andar, se desloca à frente, abrindo dimensões ainda não vistas, ampliando horizontes e emprestando significação ao próprio andar (...).

O desdobramento dessa visão integradora no acoplamento da EA à EP suscita a necessidade do acoplamento também das metodologias da pesquisa-ação existencial com a pesquisa participante, a fim de amparar o universo da experiência realizada. Enquanto uma fortalece a abordagem subjetiva e abre-se para as dimensões da arte, da poesia e também para as espirituais e multiculturais da vida, a outra põe o foco na visão crítica da realidade por sua vinculação histórica com os movimentos sociais populares. Ao mesmo tempo, pode-se observar que ambas se identificam com os princípios da emancipação, da transformação, da libertação das condições humanas subordinadoras. Barbier (2007, p. 73) explica a pesquisaação existencial dizendo que:

A pesquisa-ação existencial (P-AE) é, sem dúvida, levada a favorecer bastante o imaginário criador, a afetividade, a escuta das minorias em situação problemática, a complexidade humana admitida, o tempo da maturação e o instante da descoberta. Ela não está ligada a uma disciplina particular em Ciências Antropossociais. Dará preferência provavelmente à Psicossociologia clínica, à Antropologia e à análise institucional. Mas, na 
realidade, ela se abre para outra coisa sem ser a ciência: a arte, a poesia, a filosofia, as dimensões espirituais e multiculturais da vida.

Brandão (2006, p. 113-114) define a pesquisa participante a partir do contexto em que ela nasce, pois é nesse contexto que está a elucidação para o seu surgimento. Ele explica então que ela

\begin{abstract}
Nasce no Terceiro mundo, por oposição ao discurso desenvolvimentista nascido em e para a defesa dos interesses dos países opressores e exploradores. Esse contradiscurso postula uma organização e uma estrutura de conhecimento para que os países dominados e explorados possam articular - e defender - sua postura sociopolítica e econômica, com base em seus próprios valores e capacidades. É um processo que combina a pesquisa científica e a ação política para transformar a realidade social e econômica, para construir o poder popular em favor dos explorados [...].
\end{abstract}

Nesse sentido, fui alimentando as escolhas a partir dos referenciais teóricos buscando entender a relação entre o sujeito pesquisador e o objeto da pesquisa, também distinguindo o objeto dos demais sujeitos envolvidos, por haver de antemão um compromisso com uma ação libertadora e transformadora. Essa percepção inicial foi relevante para a definição das demais opções, pois o sujeito pesquisador adquire a consciência de que entre ele e o objeto, que está inserido na realidade investigada, há outros sujeitos envolvidos. Ao refletir sobre a pesquisa científica, Paulo Freire adverte para algumas situações que estão inseridas em questões epistemológicas implicadas na pesquisa e chama a atenção para a relação entre os sujeitos envolvidos e o objeto da investigação e, em profunda coerência com suas preocupações, nos diz:

Se me interessa conhecer os modos de pensar e os níveis de percepção do real dos grupos populares estes grupos não podem ser meras incidências de meu estudo. Dizer que a participação direta, a ingerência dos grupos populares no processo da pesquisa altera a "pureza" dos resultados implica na defesa da redução daqueles grupos a puros objetos da ação pesquisadora de que, em consequência, os únicos sujeitos são os pesquisadores profissionais. Na perspectiva libertadora em que me situo, pelo contrário, a pesquisa, como ato de conhecimento, tem como sujeitos cognoscentes, de um lado, os pesquisadores profissionais; de outro, os grupos populares e, como objeto a ser desvelado, a realidade concreta. (FREIRE, 1981, p. 35, grifos do autor)

Vejo, portanto, que essa perspectiva libertadora fortalece ainda mais a opção aqui tomada pelo acoplamento entre a pesquisa-ação e a pesquisa participante, pois a EA inserida no universo da EP proporciona a atmosfera apropriada para esse tipo de pesquisa, tomando o 
contexto como um espaço de formação e intervenção. A explicação acerca da pesquisa-ação trazida por Catalão e Rodrigues (2006, p.18), corresponde ao pensamento metodológico integrador desses campos no universo desta pesquisa. Nesse sentido elas explicam:

Ela propõe (...) um trabalho de formação grupal e individual que busca articular os saberes e habilidades das comunidades com o conhecimento científico e tecnologias apropriadas à ação ambiental e aos programas de desenvolvimento humano sustentável. Esta metodologia percebe a intervenção crítica e transformadora em uma situação-problema como uma co-formação para os seus protagonistas.

As questões que nortearam a pesquisa trouxeram águas de diferentes fontes que se encontraram ao longo do percurso. Para saber qual a contribuição da Educação Ambiental para uma aprendizagem significativa na alfabetização de adultos trabalhadores de cooperativas de resíduos sólidos, assim como para verificar qual o papel das estratégias ecopedagógicas nessa formação humana emancipatória, me lancei em águas profundas. Águas mobilizadas que brotaram da experiência de alfabetização de catadores, utilizando estratégias da EA, no campo investigado.

Sobre a pesquisa-ação Barbier (2007, p. 58) nos diz que "os técnicos podem fazer a pesquisa por si mesmos nos locais de sua atividade". A teoria da complexidade corresponde a essa opção metodológica quando aplicada à pesquisa-ação. Barbier comenta que o paradigma da complexidade "opõe-se ao paradigma da simplicidade concebido como uma análise, visando desconstruir a totalidade em unidades menores”. (BARBIER, 2007, p. 87)

Para Barbier (2007), o espírito da pesquisa-ação consiste em uma abordagem em espiral que utiliza todas as noções-entrecruzadas. "Significa que todo avanço em pesquisaação implica o efeito recursivo em função de uma reflexão permanente sobre a ação." (2007, p. 117) A esse respeito ele acrescenta que a "abordagem em espiral supõe igualmente que, mesmo se nós nunca nos banhamos duas vezes no mesmo rio, segundo a fórmula heraclitiana, ocorre-nos olhar duas vezes o mesmo objeto sob ângulos diferentes. É o espírito mesmo da multirreferencialidade". (BARBIER, 2007, p. 117)

Partindo desta reflexão, Barbier (2007, p. 118), assentando-se na concepção da teoria da complexidade sistematizada por Morin, apresenta quatro temáticas centrais a serem examinadas quando da utilização do método da pesquisa-ação: 1) a identificação do problema e a contratualização; 2) o planejamento e a realização em espiral; 3) as técnicas de pesquisaação e 4) a teorização, a avaliação e a publicação dos resultados. Para Barbier (2007, p. 118), o "método é antes um auxílio à estratégia". "O método" escreve Morin "pode modificar seu 
rumo em função das informações recebidas e dos acontecimentos imprevisíveis. Pertence ao domínio da paradigmatologia, isto é, dos princípios que vão governar o espírito quando este vai abordar um problema de conhecimento”. (BARBIER, 2007, p. 118)

A transversalização, portanto, como postura proveniente da pesquisa-ação, é a abertura para a escuta e dialogicidade ao longo do percurso da pesquisa. Essa abertura cria, contudo, uma coerência interna que demanda um rigor metodológico específico correspondente a cada nova circunstância. Inicialmente, houve o entendimento de tomar como procedimentos necessários a consulta bibliográfica que trata da temática em questão, assim como a pesquisa documental (fontes oficiais e institucionais) e a pesquisa in loco, mas outros procedimentos metodológicos foram sendo adotados por esta investigação, construídos ao longo do processo, de acordo com os princípios da pesquisa qualitativa e da pesquisa-ação. A entrevista semiestruturada foi um procedimento importante, que trouxe contribuições reveladoras do universo envolvido.

O referencial metodológico adotado traz a subjetividade como aspecto relevante da interação dos sujeitos envolvidos. Considerando a importância da subjetividade desses sujeitos, acrescenta-se a esse conjunto a opção por uma pesquisa implicada construída de forma participativa e comprometida com a emancipação dos sujeitos envolvidos.

No entendimento de Barbier (2001, p. 120), a implicação no campo das ciências humanas pode ser então definida como o profundo vínculo pessoal e coletivo do pesquisador com sua práxis científica, em função de sua história social, libidinal e de seu projeto sócio-político em ato, de tal modo que o investimento que resulte inevitavelmente de tudo isso seja parte integrante da dinâmica de toda sua atividade. (MACEDO, 2012, p. 24)

A fundamentação teórica se torna mais consistente, portanto, quanto mais coerente e integrada ela estiver com a pesquisa e com os sujeitos nela envolvidos, especialmente quando se trata de uma pesquisa realizada in loco, ou empírica, ampliando as possibilidades da investigação. Assim, a necessidade da contemplação do rigor científico durante todo o processo de construção do trabalho investigativo é premente, mas é preciso considerar que cada "vez mais se entende o fenômeno educacional como situado dentro de um contexto social, por sua vez inserido em uma realidade histórica, que sofre toda uma série de determinações". (LUDKE; ANDRÉ, 1986, p. 5) 
A experiência proporcionada por este estudo vai se inserir na diversidade das experiências da Educação Popular, conforme se refere Brandão ${ }^{13}$ (2014), mencionando Freire em uma entrevista concedida em Buenos Aires por ocasião do "Seminario Movimientos Sociales y Educación Popular", organizado pela Universidad Nacional de Luján. Quando perguntado sobre se a EP tem uma teoria própria, ele nos diz que:

Es que el mismo Paulo Freire tuvo siempre una dificultad muy grande en decir quién era. Por ejemplo: nunca fue marxista, solamente cuando viejo. En Pedagogía del oprimido utiliza a Mao-Tsé Tung, Marx, Martin Buber, que es un judío conservador, también a autores críticos pero no marxistas. Siempre, en toda su vida, fue muy ecléctico. Y por otra parte, las experiencias de educación popular fueron siempre muy diversas. Yo diría que aunque tuvimos un libro, claro, Pedagogía del Oprimido, nunca hubo una única educación popular.

Corroborando com a fala de Brandão (2014), a experiência realizada indica que a EP está em constante recontextualização. A natureza dessa investigação insere a EP no universo dessa diversidade e, assim sendo, conduz à necessidade de uma abordagem metodológica diversificada e criativa, pois ela requer ultrapassar os limites explicativos do paradigma cartesiano ainda muito presentes na produção do conhecimento, especialmente no processo de alfabetização de adultos.

\subsection{Contorno das margens definidas pelo incontível curso das águas}

A postura transversal, proveniente da pesquisa-ação, proporcionou abertura para a escuta sensível e a dialogicidade ao longo do percurso da pesquisa. A coerência interna demandada dessa postura exigiu um rigor metodológico específico correspondente a cada nova circunstância. Inicialmente, a consulta bibliográfica que trata da temática em questão, assim como a pesquisa documental (fontes oficiais e institucionais) e a pesquisa in loco, foram procedimentos necessários nesta abordagem e, portanto, previamente adotados, mas outros procedimentos metodológicos puderam ser tomados por esta investigação e construídos ao longo do processo. Todos os registros apreendidos foram dialogando com o referencial teórico que deu sustentação às análises, a partir do campo investigativo que se constituiu. Assim, explicito aspectos fundamentais que constituíram a pesquisa, elementos que se articularam e se entrecruzaram definindo as análises, no contorno de seu leito.

\footnotetext{
${ }^{13}$ Disponível em: <http://www.pagina12.com.ar/diario/elpais/1-236859-2014-01-02.html>. Acesso em: 01 mar. 2016, às $00 \mathrm{~h} 12$.
} 


\subsubsection{Os educandos colaboradores}

A pesquisa realizada na comunidade da cooperativa Acop envolveu 14 colaboradores na formação da turma, sendo 10 mulheres e 4 homens. Dentre esses, havia duas alunas que moravam nas imediações mas não eram catadoras e a Naná, uma catadora que participou como educadora popular, sendo minha auxiliar, recebendo uma bolsa da Incubadora Social. Embora tenha contado com a colaboração de 13 educandos, a permanência deles na turma foi irregular. 3 educandas saíram, em momentos diferentes, ao longo do mês de junho, outra entrou no mês de julho e saiu no final de setembro e outra que só entrou em outubro e saiu no final de novembro. Teve um catador que participou durante todo o período, mas com frequência sempre muito irregular e outros dois que decidiram frequentar a turma a partir do mês de outubro e se mantiveram até o final.

Todos os educandos sempre foram recebidos com acolhimento em qualquer momento que ingressavam na turma. O movimento das águas se manifestava ali, entre idas e vindas, me mostrando a natureza daquele grupo. Essa foi a maneira como o grupo conseguiu participar da turma, cada um inserindo-a em seus outros tantos afazeres, tentando encontrar um lugar de sentido para ela em sua vida. Considero que foi um grande espaço conquistado na vida de cada um que se dispôs a participar da experiência, cada um encontrando dentro de si um motivo para estar ali, mas, na certa, a aproximação entre o trabalho realizado e a realidade daquele lugar foi relevante para a permanência da turma durante todo o período.

\subsection{2 $\underline{O}$ período de realização da pesquisa}

A experiência de alfabetização realizada com os educandos teve a duração de 8 meses, período determinado pelo Programa AJA-Expansão. As atividades se iniciaram, nessa turma, no mês de maio e foram encerradas no mês de dezembro, do ano de 2014. As aulas aconteciam de $2^{\mathrm{a}}$ a $5^{\mathrm{a}}$ feira, das $17 \mathrm{~h} 30$ às $20 \mathrm{~h}$, horário combinado com o grupo, sendo a $6^{\mathrm{a}}$ feira reservada para a formação continuada com os educadores populares no Centro de Formação dos Profissionais da Educação - CEFPE.

Antes da constituição da turma, no entanto, houve um momento prévio de levantamento de dados para a confirmação da demanda do analfabetismo entre os catadores das cooperativas incubadas e para, a partir desse dado, poder decidir e definir quanto à constituição da turma. Esta foi uma etapa da pesquisa, que se constituiu em um procedimento in loco levando a um percurso de visitas e aproximações entre mim e o mundo dessas cooperativas. 


\subsubsection{O espaco das aulas}

Após quase dois meses com a turma funcionando em espaços provisórios, pude, finalmente, alugar uma sala e adaptá-la para a instalação da turma. A partir de então, os encontros diários se materializaram em um espaço onde as atividades foram desenvolvidas, evidenciando a relevância desse espaço para a realização da pesquisa, tão mais relevante quanto mais difícil foi encontrar esse lugar na comunidade, a ponto de tomá-lo como um lugar sagrado, um templo de encontros e partilhas. Lugar onde todos os dias as artérias marcavam o ritmo das existências compartilhadas. Um espaço onde os ensinamentos se faziam pelas trocas de saberes, despertando em cada sujeito a sua palavra e o seu sentido profundo de ser. Onde as marcas deixadas na folha branca, eram um registro das palavras escritas no coração. Assim, penso ter proporcionado as condições para a realização das atividades, assegurando um espaço físico para a instalação de uma sala de aula conectada com aquela realidade, que se tornou uma expressão dos adultos alfabetizandos que compartilhavam todos os dias a realidade daquela cooperativa, um ambiente que todos puderam acompanhar e participar de sua criação. Um lugar que era de todos, portanto, do entrecruzar de olhares, vidas e saberes.

\subsubsection{As parcerias}

A pesquisa conduziu a algumas parcerias importantes que precisaram ser feitas, pois se tratou de um campo bastante restrito e de grande especificidade: a instalação de uma turma de alfabetização de adultos trabalhadores de cooperativas de resíduos sólidos. Embora o objeto da pesquisa já estivesse previamente definido, não havia um campo pronto, preparado para uma intervenção e a inexistência das condições necessárias para o trabalho, especialmente as relativas à escolarização daqueles trabalhadores, afastava as possibilidades da experiência. Assim, as parcerias foram relevantes visando o fortalecimento das condições para que a experiência se efetivasse.

\subsubsection{O Programa AJA-Expansão}

Um Programa da SME de Goiânia direcionado para a alfabetização de adultos, que se tornou uma relevante parceria na realização do trabalho, pois a turma foi cadastrada a esse Programa e pôde receber todo o apoio dos recursos que ele oferecia. Além dos recursos didático pedagógicos nas formações e no acompanhamento à turma, também materiais didáticos e merenda escolar. Esse é um programa com mais de 10 anos de existência, portanto 
com uma vasta experiência; com vínculos com o Programa Brasil Alfabetizado, recebendo subsídio do governo federal; enfim, um programa institucionalizado por uma rede pública de educação e com uma proposta político-pedagógica bem definida. Embora a sua proposta não focalize a EA, o seu compromisso com uma educação libertadora e voltada para as especificidades da educação dos jovens e adultos, explicitado em seu PPP, favorece ao diálogo com a Educação Ambiental.

\subsubsection{A cooperativa ACOP}

Foi outra parceria fundamental. Essa cooperativa foi o ponto de convergência das buscas que se intencionava fazer, em seu entorno havia uma comunidade onde residiam os catadores que fizeram parte da turma. A cooperativa, os educandos catadores e aquela comunidade formaram o contexto onde a experiência se realizou.

\subsubsection{A Incubadora Social da Universidade Federal de Goiás}

Órgão vinculado à Pró-reitoria de Extensão e Cultura dessa universidade, foi outra parceria relevante. Ela desenvolve um trabalho imprescindível para a manutenção e organização das cooperativas orientando-lhes no processo autogestionário, na relação entre os cooperados e na contabilidade.

A esse tipo de colaboração hoje está em moda ser denominado de parceria. Considero os comentários de Munarim (2005, p. 31), acerca das parcerias, pertinente ao que ora se apresenta:

O uso da palavra parceria, hoje, é moda. Governos, empresas, organizações da sociedade civil, cada um a seu modo, todos defendem a importância das parcerias. Mais que isso, para ser (ou, pelo menos, parecer ser) moderno, no sentido de atualizado, é comum o entendimento de que, de algum modo, toda e qualquer organização tem que trabalhar em parceria. Parece até que é passado o tempo de competição, de concorrência. Agora, a voga parece ser a (re)descoberta da ação solidária.

Assim, para além de qualquer modismo que se possa imaginar, considero que essas instituições foram parceiras importantes nesse empreendimento, não somente pelo espírito solidário agregado a cada uma, mas especialmente pela troca cooperativa a que esses vínculos favoreciam a todos os envolvidos. Dessa maneira, entendo que as parcerias que se estabeleceram criaram uma rede que fortaleceu, sobretudo, o espírito cooperativo, em um espaço que buscou se afastar de competições e concorrências, sem distanciar-se, porém, dos 
desafios do mundo contemporâneo. Um espaço de pensamento crítico, mas integrativo, autônomo, dialógico, cooperativo, complexo, subjetivo e objetivo, resiliente, em busca da qualidade e sustentação da vida. Essas parcerias foram o suporte inicial para a instalação da turma que, ao longo do processo, foi se fortalecendo por conta da demanda existente, das relações que foram se estabelecendo e da minha determinação de pesquisadora superando obstáculos.

\subsubsection{Observação participante}

A natureza desta pesquisa, ao investigar a interface entre a Educação Ambiental e a Educação Popular, suscitou novos elementos provenientes do espaço dessa convivência. Em seu percurso, foram utilizadas predominantemente abordagens qualitativas junto aos vários atores sociais implicados. Os encontros do grupo foram espaço de (com)vivência, transitando pelas múltiplas dimensões da vida e lócus privilegiado da observação participante. A observação participante se deu a partir das considerações apontadas por Barbier (2007) ao que ele se refere como sendo observação participante predominantemente existencial (OPE), que me fizeram perceber os entrelaçamentos que eu possuía com aquela realidade, pois a minha participação na pesquisa se procedeu, ao mesmo tempo, como pesquisadora participante e como educadora popular, aumentando o meu compromisso com aquela comunidade.

Dessa maneira, a minha observação não podia ser outra senão a participante, pois, ao mesmo tempo que observava, compartilhava do processo me localizando em uma dimensão particular, com um tipo de implicação a que Barbier (2007) qualifica de Observação Participante Ativa (OPA) em que "o pesquisador tenta, por meio de um papel desempenhado no grupo, adquirir um status no interior do grupo ou da instituição que ele estuda. Ele está simultaneamente dentro e fora do grupo." (BARBIER, 2007, p. 126). Dessa maneira, o cuidado no desempenho dos dois papeis, ora ouvindo, observando, registrando, ora participando das discussões e intervindo, me colocava, simultaneamente, dentro e fora do grupo. Dessa relação, emergiu uma função específica a partir da conexão e inter-relação dos

papeis de educadora e pesquisadora, passando a perceber-me como educadora/pesquisadora/participante/existencial/ativa.

\subsubsection{Entrevista semiestruturada}

Este foi um procedimento relevante para a compreensão do contexto dos sujeitos envolvidos, contribuindo para a percepção do potencial de transformação suscitados pela 
inserção da EA no processo de alfabetização de adultos em cooperativas de resíduos sólidos. $\mathrm{O}$ contexto onde a pesquisa se desenvolveu me conduziu à escolha de três sujeitos para serem entrevistados, selecionados à luz do objetivo a ser alcançado e das questões que se busca responder. Por meio da entrevista semiestruturada foram recolhidos os depoimentos de Seu Iramar, do Sr. Fernando e da Elizângela (Naná). Esses entrevistados assinaram o Termo de Consentimento livre e esclarecido autorizando a utilização de seu próprio nome na pesquisa.

O Seu Iramar, além de ser o presidente da cooperativa ACOP, foi entrevistado também por sua história de luta e superação como catador e, também atualmente, junto às cooperativas. Hoje ele está envolvido com o movimento nacional dos catadores, sendo membro da coordenação nacional. É uma referência no movimento dos catadores e no ambiente das cooperativas de Goiânia. Ele foi, portanto, uma pessoa estratégica que pôde fornecer informações relevantes para a pesquisa.

O Sr. Fernando foi outro sujeito selecionado por ser coordenador geral da Incubadora Social da UFG. Ele é técnico em cooperativismo, formado pela Universidade Federal de Viçosa (MG), disse ter paixão pelo que faz e não consegue se ver trabalhando com outra coisa que não seja o cooperativismo. Por sua função, a entrevista concedida trouxe importante contribuição com informações acerca da atuação da Incubadora junto às cooperativas: como a Incubadora atua na relação com as cooperativas, como interfere, que estratégias utiliza, se existem resistências por parte das cooperativas, se há procedimentos da EA, se é feita alguma eco formação e como é feita, dentre outras.

Elizângela (a Naná) foi entrevistada por ser uma catadora, filha de catadores, que foi presidente da Acop, moradora dessa comunidade e acompanhou de perto o trabalho realizado na turma de alfabetização, por ter sido minha auxiliar como educadora popular da turma. Naná tinha concluído apenas o ensino fundamental, por isso ela não pôde ser a educadora popular da turma, porque pela diretriz do Aja-Expansão é preciso ter o ensino médio completo. Ela foi um elo de conexão muito importante entre a comunidade e a experiência realizada na turma. Naná era o apelido como gostava de ser chamada, assim ela era conhecida na comunidade.

\subsubsection{O portfólio}

Utilizado como instrumento de registro e avaliação da aprendizagem, foi um rico procedimento para essa pesquisa por fazer um registro das mudanças ocorridas. De forma simplificada, esse portfólio se constituiu em nosso campo em uma pasta caixote, com elástico, 
de uso individual, onde todos os dias cada um colocava ali o que fosse de seu interesse. Do caderno a uma flor, cada objeto com o seu sentido, a sua razão de ser. Desde o início foi combinado que esse portfólio era parte de minha pesquisa e que ele seria recolhido no encerramento da turma. Por solicitação da turma, ficou combinado que ele seria devolvido assim que a pesquisa fosse finalizada.

\subsubsection{As rodas de conversa}

Essas rodas foram estimuladas em sala de aula, por meio desse procedimento foi possível ter a avaliação dos educandos acerca das aprendizagens. Houve uma roda de conversa tematizada, organizada em um roteiro, que foi realizada no mês de outubro. Eu havia programado fazer outra roda de conversa avaliativa no final do mês de novembro, mas não foi possível. Fazer essa roda não era uma tarefa fácil porque a frequência e a pontualidade eram muito irregulares. Quando todos chegavam, e o grupo terminava de se reunir, já havia diferentes atividades sendo desenvolvidas, pois cada um que chegava era recebido com o mesmo acolhimento. A maneira que encontrei foi gravar discussões espontâneas durante as aulas, a partir dos temas discutidos na sala, na perspectiva da escuta sensível.

\subsubsection{Diário de campo}

O diário de campo foi um instrumento importante, pois ele é o registro de falas e situações que emergem do cotidiano na sala de aula. Juntamente com ele também foi feito o registro por fotografia e gravação de voz e vídeo. Além do meu diário de campo, houve também o diário da Naná, um registro que lhe foi solicitado pela Incubadora por ocasião da efetivação de seu contrato como bolsista. Forneci-lhe um caderno onde ela fez os seus registros.

\subsubsection{0 $\underline{\text { Registros fotográficos }}$}

Os registros fotográficos foram feitos com câmera digital amadora. As imagens fotográficas tiveram 3 diferentes autores: além de mim, $\mathrm{Pp}, 10$ anos, que era filho de Maria $\mathrm{P}$, gostava de colaborar fotografando o grupo. Também Naná costumava ter a iniciativa de registrar algumas atividades. Esses registros possuem um valor especial, eles fazem por si só uma narrativa de toda a história, por meio das imagens. 


\subsubsection{Pesquisa documental}

A pesquisa documental foi feita a partir da coleta de documentos da cooperativa. Atas de reuniões para eleição de presidentes, atas de decisões internas, registro da cooperativa em cartório, documento de escritura da cooperativa junto à prefeitura de Goiânia. Esses documentos foram importantes para comprovarem a institucionalização da cooperativa Acop, ao mesmo tempo que comprovam a história de lutas e superação vivida por aquela comunidade. Eles são um registro dessa história, mostrando a conquista feita e podendo servir de instrumento de fortalecimento para o trabalho daqueles catadores. Além desses, também foram selecionados documentos relativos à SME de Goiânia: proposta político pedagógica, relatórios e avaliações.

\subsubsection{Outros Procedimentos}

A partir do que foi proposto e sustentado pelo pensamento que fundamenta todo este trabalho de pesquisa, alguns procedimentos solicitados precisaram ser implementados para a efetivação da pesquisa, dentre eles:

\subsubsection{Pedido de autorização para realização da pesquisa junto ao AJA-Expansão}

Esta é uma exigência da SME para a realização de pesquisas nessa rede. No dia 02 de abril de 2014 protocolei esse pedido junto à SME de Goiânia, mas somente no dia 08 de maio recebi o retorno com o deferimento do pedido, me autorizando a realizar a pesquisa. Devido a esse procedimento, não participei da formação inicial para os educadores populares, que foi realizada durante o mês de abril.

\subsubsection{Levantamento da demanda de catadores que não sabiam ler e escrever}

Este foi um procedimento adotado de levantamento de dados para a confirmação dessa demanda, a fim de que o projeto de pesquisa pudesse ser efetivado, na forma como foi proposto desde o início. Para esse levantamento, percorri todas as cooperativas incubadas aplicando o instrumento elaborado.

\subsubsection{Conselho de ética}

Esta pesquisa se insere no subprojeto "Educação de Jovens e Adultos na Secretaria Municipal de Educação de Goiânia: história e memória", do "Projeto de Pesquisa e Extensão 
Centro Memória Viva Documentação e Referência em EJA, Educação Popular e Movimentos Sociais do Centro Oeste", estando, portanto, vinculada ao registro de ética desse centro de pesquisa.

\subsubsection{Termo de Consentimento Livre e Esclarecido}

Esse termo de consentimento foi apresentado a todos os educandos, em duas vias para cada um, com a leitura feita por mim e cada um acompanhando em sua cópia, onde eram informados e convidados a participarem da pesquisa. Assinaram, com satisfação, pela primeira vez em um documento, o próprio nome, no Termo de Consentimento. Esse foi um documento de consentimento livre esclarecido, onde autorizavam a utilizar as falas, as imagens e áudios na tese, para obtenção do título de doutora; em palestras em comunidades científicas, culturais e educativas; em publicações acadêmicas em livros e periódicos. Os educandos me autorizaram, oralmente, a utilizar o nome deles na pesquisa, mas no documento assinado consta que será mantido o anonimato, por isso os nomes foram preservados.

\subsubsection{Os instrumentos}

Esses instrumentos encontram-se colocados como apêndice, no final do trabalho.

$>$ ficha de levantamento de dados pessoais e escolares: instrumento elaborado para levantamento da demanda dos catadores que não sabiam ler e escrever junto às cooperativas incubadas.

$>$ ficha de matrícula no AJA- Expansão: A ficha de cadastro dos educandos junto ao AJA-Expansão foi uma fonte importante de coleta de dados sobre esses sujeitos.

$>$ roteiro de entrevista semiestruturada, planejamento das aulas, roteiro para roda de conversa: foram instrumentos utilizados para suporte a cada um desses procedimentos.

\subsubsection{As estratégias ecopedagógicas}

A partir dos princípios da EA e da EP, aliados ao objetivo da pesquisa, pude definir previamente algumas estratégias pedagógicas a serem adotadas. Essas estratégias foram sendo modificadas ao longo do percurso, na medida em que novas situações foram surgindo, na interação entre os sujeitos e mediante as condições reais apresentadas. Portanto, a 
metodologia definiu diversas estratégias empregadas que serviram de ponte para o alcance do objetivo almejado, enriquecendo o percurso. Dentre as que foram desenvolvidas estão:

A trajetória de vida, elemento fundante no processo de alfabetização de adultos, promovendo o diálogo entre o mundo interior e o exterior;

$>$ Eco-oficina, estratégia utilizada para a promoção dos encontros, o surgimento do diálogo, o cuidado com a vida, a formação humana e, especialmente, para o trabalho com a ecologia profunda;

$>$ Linguagem eco poética, conectando imagens e palavras a partir das sílabas do próprio nome, o letramento inserido na ampliação da percepção de si e do mundo;

$>$ Religação com a natureza através de excursões e eco atividades integradoras: visita ao Memorial do Cerrado;

> Vivências com a água, despertando uma conexão espiritual integradora e agregadora;

$>$ Caminhada ao córrego Caveirinha, para sensibilização e conversa sobre a água, com a água;

Utilização de pluralidade de textos e de gêneros textuais;

$>$ Utilização da linguagem visual para a apreciação, discussão e criação de textos com conexões entre palavras e imagens: desenhos, pinturas, colagens;

$>$ Eco temas geradores no percurso de conexão entre o trabalho com a triagem dos resíduos sólidos, as relações sociais e a natureza;

$>$ Discussão de temas e/ou proposição de oficinas com a colaboração e participação direta de convidados: companheiros das cooperativas, professores, técnicos, artistas plásticos, artesãos...

$>$ Produção artística a partir dos resíduos sólidos que a cooperativa recebe;

$>$ Parceria com professor de artes e graduando bolsista, para dar suporte em produções artísticas;

Organização de uma exposição dos trabalhos artísticos produzidos;

Todas essas estratégias ecopedagógicas se constituíram em um importante potencial de transformação, foi por esse meio que as ações se efetivaram fazendo com que os educandos pudessem vivenciar situações que os conduzissem a refletir sobre a sua existência e sobre a realidade. As estratégias ecopedagógicas são capazes de transformar o ser e, transformando-o, ele modifica o meio onde habita e o mundo em que vive.

O que se percebe é que este estudo transita por um novo campo, o campo da educação ambiental popular proveniente da junção da Educação Popular e da Educação Ambiental. A 
criação desse campo promove a inserção de uma discussão necessária não somente na alfabetização, mas em todo trabalho com a EJA, pois se trata de dois universos que, na verdade, não se separam se considerarmos que todos somos seres que existimos e alimentamos a vida compartilhando uma história construída em um mesmo ambiente.

O entrecruzar dos elementos que contextualizam a pesquisa colaboram com a análise interpretativa da realidade, suscitando algumas categorias. Sabemos que as categorias são formas do pensamento que expressam termos mais gerais de organização dos elementos, permitindo melhor representação da realidade, mas concordo com Lüdke e André (1986, p. 49) quando recomendam que é necessário ir além, é necessário haver um esforço de abstração, pois apenas a categorização não esgota a análise. Esse é, portanto, o meu empenho neste momento de apresentação da pesquisa, ou seja, ultrapassar a descrição, buscando de fato acrescentar algo à discussão já existente sobre o assunto focalizado. Aí está o meu esforço de abstração, procurando ultrapassar os dados, tentando estabelecer conexões e relações que possibilitem a proposição de novas explicações e interpretações. Buscando maior aproximação à pesquisa que estou apresentando, considero pertinentes estas considerações trazidas por Gadotti (2001, p.82).

É nesse contexto, nessa travessia de milênio, que devemos pensar a educação do futuro e podemos começar por nos interrogar sobre as categorias que podem explicá-la. As categorias "contradição", "determinação", "reprodução", "mudança", "trabalho" e "práxis", aparecem frequentemente na literatura pedagógica contemporânea, sinalizando já uma perspectiva da educação, a perspectiva da pedagogia da práxis. Essas são categorias consideradas clássicas na explicação do fenômeno da educação. Elas se constituem um importante referencial para a nossa prática. Não podem ser negadas, pois ainda nos ajudarão, de um lado, para a leitura do mundo da educação atual e, de outro, para a compreensão dos caminhos da educação do futuro.

O percurso desta pesquisa foi delimitado pelas margens das águas que o alimentaram, ou seja, se o compromisso é de mudança, de transformação, percebi que, além das categorias tradicionais da pedagogia da práxis, havia a necessidade de considerar, especialmente, as categorias nascidas da cotidianidade da experiência. Assim, toda a experiência vivida gerou um contexto decorrido dos elementos que o constituíam: a reciclagem, a cooperativa, as parcerias, a sustentabilidade, a fome, a persistência, o cuidado, a confiança, a escuta, a sensibilização, a emoção, o empenho, a participação, a partilha, a transcendência, a espiritualidade, a alfabetização, a formação, que brotavam no percurso, definindo a trajetória. A presença desses elementos é percebida ao longo de toda a exposição da pesquisa e eles vão 
surgindo de diferentes maneiras a partir dos contextos que os originam, favorecendo o cruzamento dos dados, o relacionar dos fatos, criando uma tessitura capaz de acrescentar algo ao já conhecido, em coerência com a perspectiva teórica adotada, para fazer a análise de conteúdo. A esse respeito, Franco (2012, p. 22) traz algumas observações importantes para a opção de análise adotada nesta pesquisa, ao falar sobre a análise de conteúdo, acrescentando que

\begin{abstract}
Além disso, análise de conteúdo requer que as descobertas tenham relevância teórica. Uma informação puramente descritiva não relacionada a outros atributos ou às características do emissor é de pequeno valor. Um dado sobre o conteúdo de uma mensagem deve, necessariamente, estar relacionado, no mínimo a outro dado. O liame entre este tipo de relação deve ser representado por alguma forma de teoria. Assim, toda a análise de conteúdo implica comparações contextuais. Os tipos de comparações podem ser multivariados. Mas, devem, obrigatoriamente, ser direcionados a partir da sensibilidade, da intencionalidade e da competência teórica do pesquisador. (FRANCO, 2012, p. 22)
\end{abstract}

O desafio é lançado e busco a coerência para segurar o leme. O conceito de dialogicidade apresentado por Paulo Freire (2013, p. 129) acrescenta uma contribuição especial a essas reflexões quando ele explica a sua concepção por meio de "em que se funda ela". Ao apresentar essa compreensão ele o faz considerando que ela se manifesta na prática da natureza humana e da democracia, mas se detém ao falar da exigência epistemológica contida na dialogicidade. Assim, ele entra nas questões de método, corroborando com Franco, comentando que:

Por uma questão de método, jamais me dirijo ou oriento diretamente minha
atenção ao objeto que me desafia e que procuro conhecer. Pelo contrário,
"tomando distância epistemológica" do objeto de que resulta minha
"aproximação" a ele, o faço "cercando" o objeto. "Tomar distância
epistemológica" do objeto significa objetivá-lo, "tomá-lo" em nossas mãos
para conhecê-lo, enquanto o "cerco epistemológico" é a operação na qual,
para melhor me apropriar da substantividade do objeto, procuro decifrar
algumas de suas razões de ser. O "cerco epistemológico" não é uma tentativa
de isolar o objeto e apreendê-lo em si. No "cerco epistemológico" procuro
compreendê-lo nas suas relações com outros objetos, sobretudo, como já
disse, procuro suas razões de ser. (FREIRE e FREIRE, 2013, p. 129, Grifos
do autor)

A comunidade onde a pesquisa se realizou era constituída por uma teia de elementos definidores da participação dos catadores colaboradores em seu processo de alfabetização, determinantes da maneira como os educandos colaboradores puderam participar da experiência. A localização dos elementos dessa teia, a sua razão de ser e o entrecruzar das 
informações criaram uma tessitura geradora de unidades temáticas que serão apresentadas e discutidas no Capítulo 5. 


\section{CAPÍtUlO 4}

Cooperativas de resíduos sólidos: movimento das águas no sustento da vida

Figura 17 - Resíduos da vida

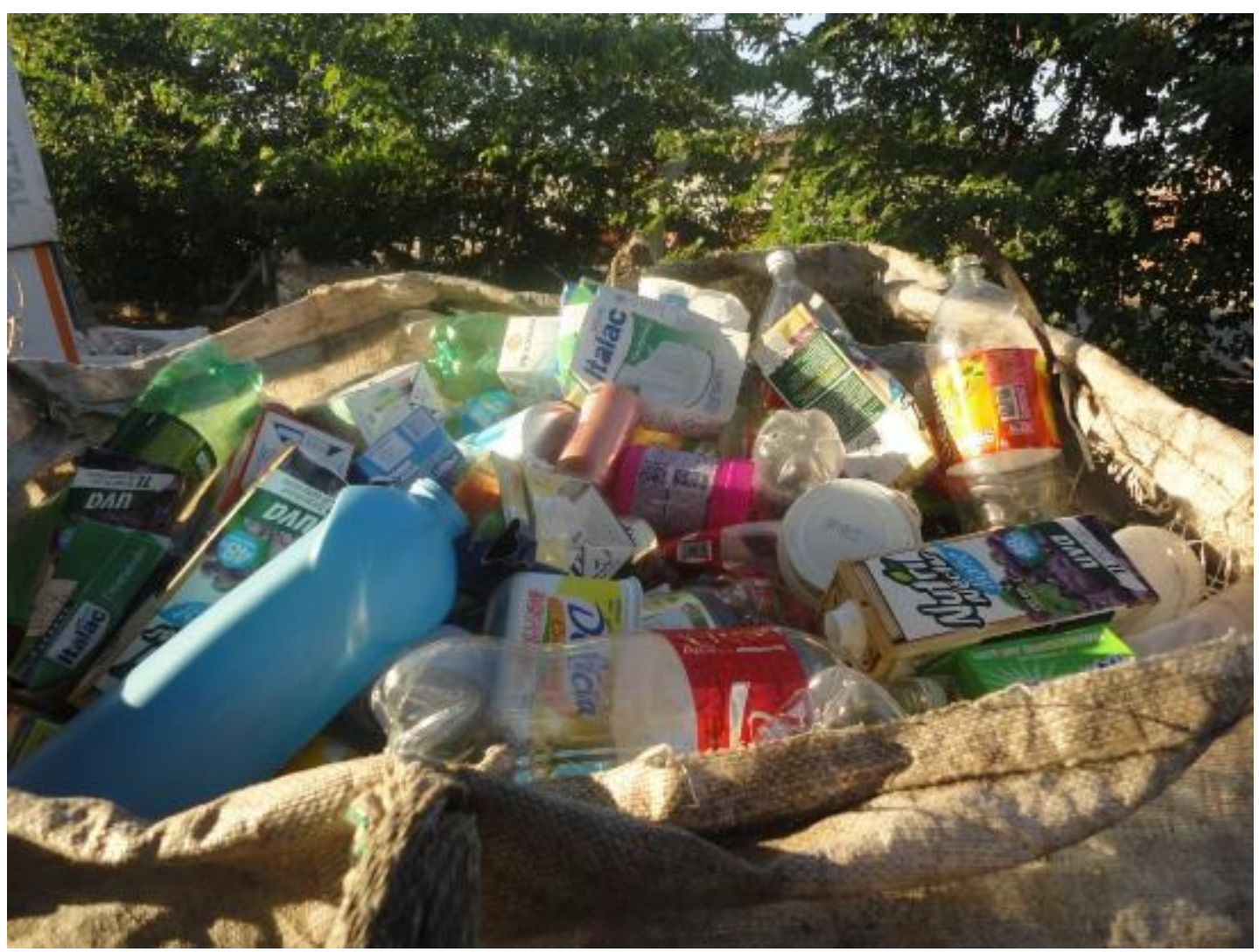

Fonte: acervo da pesquisa. Ano: 2014. 


\title{
CAPÍTULO 4 - COOPERATIVAS DE RESÍDUOS SÓLIDOS: MOVIMENTO DAS ÁGUAS NO SUSTENTO DA VIDA
}

\author{
É, cooperação já fala: cooperar e agir, que é ação. \\ Pra cooperar, a gente tem que cooperar pra ter uma ação. \\ Existe uma quantidade de trabalho aqui \\ que a gente tem que juntar um grupo aqui \\ e vamo definir quem vai fazer o quê e juntos. \\ Seu Iramar
}

\subsection{Introdução: partilhando as águas da cooperação}

O pertencimento é um tema recorrente nesta pesquisa e agora o temos como chave para a cooperação. Nas relações humanas, o sentido da ação se faz no pertencimento. A cooperação se distingue de uma ação puramente altruísta, não se trata de uma simples dedicação ao outro, mas, principalmente, uma troca onde todos se beneficiam com a ação. A cooperação é uma forma de relação resultante da evolução do ser, que se percebe capaz de fazer junto, compreendendo que com o outro ele pode realizar mais que sozinho, com o outro ele pode realizar o que não é possível realizar sozinho. A cooperação gera sentimentos verdadeiros de partilha, bem estar, satisfação, gratidão, amorosidade, alegria. Sentimentos partilhados pela evolução do ser. Dessa maneira, a cooperação, a ética e a sustentabilidade são elementos acoplados em interação permanente fecundando as águas por onde a EA navega. Este entendimento vai ao encontro do que Ribeiro (2014, p. 59) comenta sobre cooperação.

A cooperação entre as pessoas acontece quando existe empatia e abertura.
Cooperamos com aquilo que acreditamos ser importante para nossas vidas
ou para a sociedade. Para que haja cooperação é preciso que as pessoas se
sintam parte do processo coletivo ou que se identifiquem com a causa
comum. No campo institucional o mesmo princípio se aplica, pois uma
instituição se interessa em cooperar em uma iniciativa onde os
posicionamentos institucionais sejam respeitados e tenham espaço para se
expressar.

Neste capítulo, se apresenta a cooperação como uma forma de organização social humana, mas com uma compreensão ampliada, aberta à percepção da cooperação como uma organização presente em todas as manifestações da vida na natureza. Assim, perpassando por este entendimento ampliado de cooperação, este capítulo traz o cooperativismo como uma forma de organização social humana, uma proposta de mudança num mundo orientado pela lógica de mercado, pelo lucro, pelo grande capital. Passando pela origem dessa organização, apresentando essas cooperativas no Brasil a partir do contexto que as gerou, chega às 
cooperativas de resíduos sólidos em Goiânia, especialmente à cooperativa ACOP, campo desta pesquisa.

Essa incursão vai demonstrar a relevância desse tipo de organização como alternativa para a reorganização da sociedade, sob os princípios da cooperação e da solidariedade, em lugar dos princípios da competição, rivalidade, disputa. As cooperativas são um espaço de trabalho e de expressão dos sujeitos que as fazem, cada cooperativa possui uma história, cada história é parte de uma teia tecida nas sombras da sociedade. A aproximação com a pesquisa registrou um pouco do que se passa no mundo interno dessas cooperativas. As reivindicações, as lutas e os desafios, envoltos em sonhos e emoções, em aprendizagens e ensinamentos. A sustentabilidade e a manutenção da vida no planeta submersas nas relações humanas que se estabelecem no interior de cada uma.

\subsection{As águas da Educação Ambiental no movimento entre a cooperação, o cooperativismo e as cooperativas de resíduos sólidos}

A cooperação é água que jorra intensa da fonte da Educação Ambiental. A natureza integradora da EA tem a cooperação como pilar de sua prática e a pesquisa realizada em uma comunidade no entorno de uma cooperativa de resíduos sólidos fez despontar a cooperação como tema gerador de aprendizagens e saberes na prática pedagógica da Educação Ambiental. A cooperação está na fonte da vida, inúmeros estudos têm demonstrado que, em seus diferentes níveis e formas de manifestação, os seres necessitam ajudar-se mutuamente para a garantia de sua sobrevivência. A competição gera sentimentos e pensamentos que se opõem à manutenção da vida, que levam à morte. A cooperação, ao contrário do que as relações sociais predominantes estabelecem, assegura particularidades onde todos participam da elaboração da vida. Em seus estudos, observando a natureza para compreender a sociedade humana, Kropotkin (2009, p. 22) apresenta que

A sociabilidade e a luta de todos são, no mesmo grau, uma lei da Natureza. É claro que seria dificílimo estimar, mesmo que superficialmente, a importância numérica relativa de ambas as séries de fatos. Mas, se nos valermos de uma prova indireta e perguntarmos à Natureza "Quem são os mais aptos: aqueles que vivem em guerra ou aqueles que se apoiam mutuamente?", vemos de imediato e sem sombra de dúvida que são estes últimos. Os que adquirem hábitos de ajuda mútua têm mais chances de sobreviver e atingem, em suas classes respectivas, o desenvolvimento mais elevado do intelecto e da organização corporal. Considerando os incontáveis fatos que podem ser apresentados para corroborar essa visão, podemos dizer com segurança que tanto a ajuda mútua quanto a luta de todos contra todos são uma lei da vida animal; mas enquanto fator de evolução, a primeira tem 
provavelmente uma importância muito maior, na medida em que favorece o desenvolvimento dos hábitos e características que asseguram a manutenção e a evolução da espécie, além de maior bem-estar e melhor qualidade de vida para o indivíduo com o menor dispêndio de energia.

As ideias de Kropotkin (2009) evidenciam que essas forças estão presentes em nossa sociedade, ou seja, "tanto a ajuda mútua quanto a luta de todos contra todos". É entre essas forças que nos movimentamos, mas já é momento da humanidade alertar-se de que, neste atual estágio de vida planetária, ela tem a capacidade de fazer suas escolhas e definir sobre que tipo de sociedade deseja ter, decidindo sobre o seu próprio destino e o da vida no planeta. O modelo capitalista, determinante das relações sociais, profundamente enraizado entre os humanos, se alimenta da competição e a competição se nutre na seleção onde o vencedor é sempre aquele a quem é dada a melhor condição de competir, é aquele a quem as homenagens são direcionadas, enquanto o perdedor é retirado de cena e entregue às suas mazelas. Singer (2002, p. 10) comenta que

O que importa entender é que a desigualdade não é natural e a competição
generalizada tampouco o é. Elas resultam da forma como se organizam as
atividades econômicas e que se denomina modo de produção. O capitalismo
é um modo de produção cujos princípios são o direito de propriedade
individual aplicado ao capital e o direito à liberdade individual. A aplicação
destes princípios divide a sociedade em duas classes básicas: a classe
proprietária ou possuidora do capital e a classe que (por não dispor de
capital) ganha a vida mediante a venda de sua força de trabalho à outra
classe. O resultado natural é a competição e a desigualdade.

Segundo Lima (2013, p. 31): “As origens históricas nos mostram que a economia solidária resgata as lutas dos trabalhadores no início do século XIX, sob a forma de cooperativismo, que servia como manifestação contra o avanço avassalador do capitalismo industrial." O Cooperativismo surgiu, então, como uma forma de organização social que contribuísse para o fortalecimento dos trabalhadores e a melhoria das condições de vida, se orientando pelos princípios da organização autogestionada, ou seja, um tipo de organização em que não há patrão, todos participam coletivamente das decisões em igualdade de condições.

Considerando Singer (2013), a crise inflacionária, ocorrida no Brasil e agravada a partir dos anos 1980, perdurou por quase duas décadas e gerou grande instabilidade econômica e social. Essa crise submeteu as classes trabalhadoras a intensas ondas de exclusão social e econômica que se manifestavam na forma de desemprego em massa, favelização e precárias relações de trabalho. Esse contexto fortaleceu o surgimento e a propagação dos 
empreendimentos econômicos solidários como alternativa de sobrevivência das classes trabalhadoras fortemente afetadas pelos vários planos de congelamento de preços.

Os trabalhadores assim vitimados reagiram adotando diferentes estratégias de sobrevivência, uma das quais tomou a forma de economia solidária, que se caracteriza por iniciativas de produção, distribuição e consumo organizadas por agrupamentos de trabalhadores que criam empreendimentos, dos quais tem a posse coletiva, autogeridos democraticamente pelo conjunto deles e cujos ganhos são repartidos pelos sócios segundo critérios de justiça distributiva, em proporção à quantidade de trabalho realizado por cada um. (SINGER, 2013, p. 7)

Segundo Singer, (2002) o cooperativismo chegou ao Brasil no início do século XX, trazido pelos imigrantes europeus. Aqui, tomou a forma de cooperativas de consumo, as criadas para o abastecimento dos associados, e de cooperativas agrícolas voltadas para o trabalhador do campo. Com a chegada das grandes redes de hipermercados, muitas cooperativas de consumo fecharam, enquanto as cooperativas agrícolas se expandiram e foram se descaracterizando, transformando-se em grandes empresas agroindustriais e comerciais. Essas cooperativas nunca foram autogestionárias e, atualmente, tanto as cooperativas de consumo, como as agrícolas são operadas por equipes assalariadas.

De um modo geral, o cooperativismo representou uma importante alternativa para a crise econômica iniciada na década de 1980 no Brasil. De acordo com Singer (2002), nas décadas de 1980 e 1990 o Brasil se desindustrializou e muitos postos de trabalho foram fechados gerando desemprego em massa. A economia solidária reviveu o país tomando a forma autogestionária e atendendo sob diferentes modalidades. A Cáritas, entidade ligada à Conferência dos Bispos do Brasil (CNBB), financiou milhares de pequenos projetos denominados Projetos Alternativos Comunitários, conhecidos como PACs. Além desse movimento, houve também outro muito importante com a tomada de empresas falidas, ou em vias de falimento, pelos trabalhadores, que as transformavam em cooperativas autogestionárias.

Para o alcance dos seus propósitos, a Organização das Cooperativas do Brasil (OCB) explica que as cooperativas necessitam basear-se em valores de ajuda mútua, responsabilidade, democracia, igualdade, equidade e solidariedade e acreditar nos valores éticos de honestidade, transparência, responsabilidade social e preservação do ambiente para o desenvolvimento sustentável. Por esses valores nasce a economia solidária no seio do cooperativismo, ao mesmo tempo em que cultiva sua interface nos princípios da EA evidenciando que há portas abertas para essa interlocução. A EA transversalizada nesse 
ambiente pode, portanto, criar estratégias específicas capazes de contribuir para a melhoria das relações e do trabalho nas cooperativas, facilitando o alcance de seus propósitos. Sobre o entrelaçamento entre economia solidária e cooperativismo, o professor Frantz (2012, p. 2526) comenta que

A organização de um empreendimento solidário, ao tirar o indivíduo de seu mundo particular, relacionando-o com os outros, pelos laços sociais da amizade, da emoção, da razão, da associação, da cooperação, construindo espaços coletivos, desperta a responsabilidade social e a solidariedade, elementos fundamentais ao desenvolvimento do ser humano e de seus espaços de vida. Os seres humanos se humanizam pelo reconhecimento solidário e cooperativo do outro.

Uma experiência enriquecedora do cooperativismo no Brasil se dá com a entrada do MST nesse movimento. O MST adotou a forma de cooperativas autogestionárias acomodando os princípios desse sistema cooperativista à sua realidade junto aos assentamentos. Criou, então, o Sistema Cooperativista dos Assentados (SCA), para promover o seu sistema de agricultura. Criado de 1989 a 1990 o SCA conta com mais de 80 cooperativas espalhadas por todo o território nacional, por meio das quais fortalece o movimento cooperativista nacional. As inúmeras dificuldades vividas pelo MST no interior de seu movimento cooperativista não diminui a força do encontro das águas contidas nesses movimentos.

Singer (2002) comenta também sobre outro componente da economia solidária que tem apresentado um relevante serviço. São as Incubadoras Tecnológicas de Cooperativas Populares (ITCPS), entidades universitárias, que atuando de maneira multidisciplinar, incubam cooperativas e grupos de produção, dando-lhes formação em cooperativismo e economia solidária e apoio técnico, logístico e jurídico para que possam viabilizar seus empreendimentos autogestionários. Este foi o tipo de atuação encontrado na Incubadora Social da UFG, entidade por meio da qual localizamos as cooperativas que fizeram parte desta pesquisa estando todas vinculadas a essa Incubadora.

A Incubadora Social da UFG possui uma atuação direta junto às cooperativas de resíduos sólidos de Goiânia. Estas, por sua vez, possuem uma natureza complexa, multidimensional e multirreferencial que envolve as mais diversas áreas de conhecimento. Dessa maneira, essa Incubadora incorpora em sua atuação toda a diversidade do conhecimento humano e o seu quadro é composto por técnicos, professores, pesquisadores e estudantes das diversas áreas do conhecimento, tornando-se um rico ambiente interlocutor de pesquisas científicas. A colaboração de toda essa equipe foi relevante para a realização desta pesquisa, percebi que os estudantes bolsistas que me acompanhavam eram pessoas que 
possuíam um vínculo estreito com as atividades, desempenhando-as com desenvoltura e envolvimento. Percebi, ainda, no entanto, que, por tratar-se de uma instituição social cuja atuação está envolvida eminentemente com as relações humanas e com as cooperativas de resíduos sólidos, é preciso que ela olhe para a sua própria ecologia, percorra os seus caminhos internos, por meio dos caminhos internos de cada um dos que a fazem, desenvolvendo a ecologia humana e a percepção do ser, em meio à teia que os envolve.

As cooperativas de catadores se sustentam dos resíduos sólidos e estes, por sua vez, se originam na caminhada da humanidade embasada num modelo de desenvolvimento que valoriza o lucro e a acumulação de capital e entende que as inovações tecnológicas, explorando ilimitadamente a natureza, podem responder a todos os desafios sociais. O planeta Terra vem demonstrando que não suporta mais esse modelo, causador do consumo desenfreado e, em decorrência, do desperdício, gerando os resíduos sólidos que, paradoxalmente, são hoje fonte de sustentação de muitas famílias que trabalham nas cooperativas. A lei $\mathrm{n}^{\mathrm{o}} 12.305$, de 2 de agosto de 2010, que institui a Política Nacional de Resíduos Sólidos, item XVI, Capítulo II, define resíduos sólidos como sendo

\begin{abstract}
Material, substância, objeto ou bem descartado resultante de atividades humanas em sociedade, a cuja destinação final se procede, se propõe proceder ou se está obrigado a proceder, nos estados sólido ou semissólido, bem como gases contidos em recipientes e líquidos cujas particularidades tornem inviável o seu lançamento na rede pública de esgotos ou em corpos d'água, ou exijam para isso soluções técnica ou economicamente inviáveis em face da melhor tecnologia disponível. (BRASIL, 2010, p. 11)
\end{abstract}

As cooperativas de resíduos sólidos se constituem como uma nova modalidade de trabalho dentro das relações sociais e se fortalecem pela relevância de sua atividade, embora sem esse reconhecimento, devido à grande quantidade de resíduos produzida diariamente por cada um de nós. Agora, elas fazem parte de nossa cadeia, a nossa vida passa também pelas cooperativas de resíduos sólidos. Em sua lida de todo dia, devido ao serviço braçal que a atividade requer, elas estão incorporando uma parcela da sociedade que se encontrava sem trabalho, sem perspectiva de vida, marginalizada, alguns vivendo nas ruas. A mesma parcela que detém uma baixa escolaridade e falta de mão de obra especializada. Por essa razão, encontra-se em suas comunidades um número expressivo de adultos analfabetos. Sob esse aspecto, as cooperativas estão representando também uma solução de acomodação social, um lugar para essas pessoas. As cooperativas são a consequência do modelo de sociedade que se alimenta pela produção de rejeitos enquanto elas, pelas sobras humanas. As cooperativas são, portanto, o lugar onde esses rejeitos se encontram, o lugar onde, por vias tortuosas, as águas 
encontram seu fluxo. Sob essas condições, não poderia gerar outro tipo de inclusão senão uma inclusão precária e degradante decorrente de uma sociedade cuja compreensão de desenvolvimento se localiza na contramão da sustentabilidade, da solidariedade, da vida.

No prosseguimento desse movimento, os resíduos sólidos provenientes do consumo humano tornaram-se um valioso produto de negociação no mercado, sendo, não raro, alvo de disputa e de exploração entre quem fornece e quem compra. Ou seja, entre as cooperativas e as empresas recicladoras. As negociações que aí se estabelecem são paradoxais em relação a uma política de sustentabilidade, pois enquanto por um lado educa-se para uma relação de preservação da natureza, por outro lado, a disputa pelos resíduos sólidos no mercado dos recicláveis incentiva ao consumo e ao desperdício, visando maiores somas. Esse é um desafio do universo das cooperativas que está na soma dos movimentos interno e externo de cada uma. Essa situação chama a atenção para o papel da Educação Ambiental junto às comunidades, a fim de que não se tornem vítimas desses interesses.

Atualmente, falar em resíduos sólidos domiciliares remete à coleta seletiva e
à política dos 3 Rs: reduzir, reaproveitar e reciclar os resíduos. No entanto, de
uma maneira geral, a ênfase dos programas de coleta seletiva está no
reaproveitar e no reciclar e não no reduzir o consumo, que se caracteriza
como o principal problema. (ZANETI, 2006, p. 74)

Desse modo, embora a organização se dê por meio do cooperativismo, o objeto da negociação, ou seja, os resíduos sólidos, são provenientes da relação de consumo da sociedade, indicando, portanto, que não basta pensar uma alternativa econômica de distribuição democrática da renda. É fundamental pensar também na preservação da natureza e dos recursos naturais e refletir sobre a responsabilidade de todos na construção de um mundo melhor. Nesse sentido, a educação, e mais especificamente a Educação Ambiental, por meio de intervenções pedagógicas, traz a possibilidade de ampliar a consciência para que essa condição seja percebida, compreendida e modificada.

Atualmente, os resíduos sólidos têm sido objeto de muitos ensinamentos e aprendizagens, pois a sustentabilidade do planeta sofre uma ameaça cada vez maior. Nas cooperativas de resíduos sólidos em Goiânia, assim como em toda a sociedade, é o mesmo modo de produção capitalista que afeta o princípio da sustentabilidade. Com a intenção sempre direcionada para o lucro, para a acumulação de bens, a ganância, as relações humanas vão se tornando aviltadas mediante a força do mercado, onde tudo tem um preço. Atualmente, com a percepção das ameaças de exaustão da natureza, as cooperativas surgem assumindo um papel da maior importância para a sustentabilidade ambiental, pois são elas que recebem os 
resíduos sólidos coletados nas cidades, fazem a triagem desse material, separando por categorias, e vendem para as indústrias recicladoras. Elas são um artifício necessário criado pela dinâmica ecossistêmica do tipo de desenvolvimento criado pela humanidade. Nesse movimento, é importante considerar, no entanto, as implicações que a reciclagem pode gerar. A esse respeito, vejo a pertinência de algumas ponderações trazidas por Loureiro (2013, p. 75) ao considerar que

É consensual entre nós que a reciclagem é necessária e algo presente na dinâmica ecossistêmica. Contudo, focar a prática educativa aí, desconsiderando o modo de produção, é ignorar que esta, no "livre mercado", serve ao processo de ampliação da acumulação capitalista e é um estímulo ao consumismo (desde que reciclemos, podemos consumir sem limites - Zacarias 2000). A reciclagem tem que ser pensada, como qualquer outra categoria, como relação. Ou seja, para ser efetiva, segundo os interesses ambientalistas democráticos, é preciso ser problematizada, articulada com aquilo que a define (estilos de vida, padrão de consumo e de produção, quem se apropria dos benefícios da reciclagem etc.) e realizada para a transformação das relações e, portanto, da realidade.

A relação de mercado afeta o movimento interno e externo dessas cooperativas, comprometendo o ritmo de trabalho para aumentar a renda e a relação de comércio entre elas e as indústrias recicladoras dos resíduos sólidos. Nesse movimento, nota-se que o ambiente das transações comerciais estabelecidas se assenta na prevalência do reciclar, pois, de diversas maneiras, as indústrias lucram com isso, até mesmo vendendo a imagem de sustentabilidade. Para elas, portanto, quanto maior o consumo, maior o seu lucro, maior será a quantidade de material para o comércio. Ao mesmo tempo, com a reutilização e a reciclagem dos resíduos, passa a existir a ideia de que o problema do material inorgânico está resolvido e o equilíbrio da sustentabilidade restabelecido, estimulando o consumo. Sabemos, no entanto, que na contramão desse movimento, uma relação de sustentabilidade não pode ser construída sem a redução do consumo. É nesse lugar que se inicia a relação de preservação da natureza, um lugar que exige atitude, portanto, desafiador e cheio de enfrentamentos.

Reduzir, no contexto da sustentabilidade, traz implicações de diversas naturezas e dimensões. Em um mundo de relações estimuladas pelo consumo e reguladas pelo mercado, reduzir constitui uma transformação profunda de pensamentos e atitudes, conduz ao reencontro consigo e com as reais necessidades do homem e da humanidade, um reencontro com tudo o que alimenta a vida, portanto, reduzir significa romper com o consumo e os apelos do mercado. Nessa condição, a humanidade adquire o poder de decidir sobre o futuro da vida no planeta Terra escutando o chamado da natureza para a construção de uma 
sociedade sustentável, ou atendendo aos apelos do mercado que se alimenta da ganância, da competição, do desequilíbrio, da desarmonia, do conflito, de conquistas materiais indevidas, da limitação da vida. É esse o dilema por onde se inicia o pensamento da sustentabilidade e das transformações necessárias para a construção de uma sociedade sustentável. Brandão, (2005, p. 87-88) atendendo o seu compromisso com a vida, explica o seu entendimento sobre uma sociedade sustentável.

Como um princípio de Vida oposto à ideia de um crescimento econômico ilimitado, uma sociedade sustentável é a que busca mudanças e transformações que satisfaçam as verdadeiras vocações e necessidades dos seres humanos. Que realizem a vocação humana à felicidade sem comprometer, agora e para o futuro, as condições de equilíbrio e harmoniosa fertilidade da Natureza e, de maneira concreta, do meio ambiente diretamente envolvido em qualquer processo de socialização da Natureza.

Além de ser bastante realista, pois se trata de nada mais nada menos do que garantir a nossa própria sobrevivência, junto com a Vida na Terra, a ideia de sociedades sustentáveis é inovadoramente generosa e solidária para com o presente e o futuro.

[...] Ela pretende transformar pessoas e direcionar nações e povos no rumo de um espírito de crescente cooperação entre todos. No rumo de uma relação de socialização da natureza sustentável e recriadora da Vida. No rumo, ainda, de partilhas equitativas, inclusivas, gratuitas e generosas dos frutos da terra e dos bens e recursos derivados de nosso trabalho junto a ela, com vistas à uma universal regeneração da Natureza e de nós próprios. (Grifos do autor)

O analfabetismo ambiental é o grande obstáculo para a coleta seletiva, é ele o responsável pela falta de estrutura para a coleta seletiva e a criação de cooperativas, na grande maioria dos municípios. As pessoas ignoram e não se dão conta da importância de seu papel nessa teia, ou melhor, não se veem fazendo parte de uma teia. Ao mesmo tempo, as cooperativas de resíduos sólidos trazem com elas muito mais que os detritos reaproveitáveis da sociedade, elas são uma expressão da composição daquilo em que a civilização humana se transformou. O comércio, o consumo, o desperdício, a exploração, a sobra, a exclusão, mas também a cooperação, a solidariedade, o trabalho, a emoção, as vidas, tudo isso se encontrando ali. Nas mãos dos catadores a triagem, o reaproveitamento, o retorno e, mesmo que muitas vezes sem ter consciência de sua obra, a preservação da natureza, a sustentabilidade.

Os olhares, cada vez mais, têm se voltado para esse grupo de trabalhadores que vem crescendo, se articulando e ressignificando o que até há pouco tempo muitos consideravam 
lixo. Ainda assim, o que geralmente é lixo para os que consomem, para os que se encontram fora do padrão de consumo da modernidade isso é desperdício, é luxo. O papel fundamental que estão desempenhando em relação ao meio ambiente está produzindo uma nova lógica de relação para o desenvolvimento sustentável. Assim, a institucionalização do trabalho do catador, por meio das cooperativas de resíduos sólidos, vem contribuindo para a articulação política dos catadores, que passam a se ver como uma categoria profissional. E, como categoria, enfrentam muitas dificuldades, motivando inúmeras reivindicações para a melhoria das condições de trabalho e de vida. Assim, se fortalece a cada dia o Movimento Nacional dos Catadores de Material Reciclável (MNCR).

O site desse movimento apresenta, na aba "Sobre o Movimento", o entendimento que têm acerca de seu papel na sociedade, valorizando o trabalho dos catadores e dando visibilidade a essa categoria profissional. O documento me levou a apreender que o movimento já possui um nível bem articulado e politizado. Nesse documento eles explicam o que é o movimento em três partes: a primeira "O que é o movimento", a segunda "Nossa Missão" e a última "Nossos Princípios". Por essas partes vê-se que o movimento organiza os catadores e catadoras em todo o Brasil, buscando a valorização dessa categoria. O movimento tem o objetivo de garantir o protagonismo dos catadores sob o princípio de independência de classe em uma ação direta popular, com a participação efetiva em tudo que envolve sua vida, abrindo caminho para a transformação da sociedade. Além disso, se compromete com a construção de sociedades justas e sustentáveis orientados pelos princípios de auto-gestão, ação direta, independência de classe, solidariedade de classe, democracia direta e apoio mútuo. Falam, portanto, em categoria, solidariedade, luta contra a exploração, em liberdade.

Esse documento demonstra que já existe um movimento bem articulado, expressa o nível de consciência que eles possuem acerca de seu papel para a sustentabilidade e para a sociedade. De modo geral, passa a ideia de que há nesse movimento influência de um modelo de movimento social que já possui uma estrutura assentada em concepções teórico filosóficas bem determinadas. Ao mesmo tempo, não faz referência à escolarização, ao direito de estudar, da criação de uma escola para os catadores, de uma pedagogia escolar integrada ao movimento, às pedagogias de suas lutas e reivindicações. Vejo, portanto, uma lacuna que interpela por um trabalho de reaproximação da escola, colocar isso na pauta das reivindicações, a fim de que todos possam iniciar e/ou dar continuidade aos estudos, transversalizando-os pela EA, pois a EA constrói estratégias que partem das particularidades desse universo, trazendo a sensibilização, a emoção, a percepção do ser, o pertencimento à 
vida, à sociedade, ao planeta, ao cosmos. Estratégias integradoras, enfim, pela construção de uma escola específica, feita pelos catadores, capaz de garantir a escolarização desses sujeitos.

Ao longo da pesquisa, percebi também o distanciamento desse processo de escolarização dos catadores e observei que esse distanciamento existe até mesmo no MNCR. Seu Iramar, presidente da Acop no ano 2014, catador atuante, representante do movimento nacional dos catadores no Estado de Goiás e um dos membros da Comissão Nacional do MNCR, sabe do valor da escolarização para o fortalecimento das lutas e, consequentemente, para a melhoria das condições de trabalho e vida. Em entrevista concedida para esta pesquisa no dia16/04/2015, ele comenta sobre a importância do catador saber ler e escrever.

(1) Pra todo cidadão, assim, que tem conhecimento da verdade de leitura, pra gente é fundamental sê saber ler e escrever. No processo de cooperativa, a gente vai trabalhar também com vários tipos de equipamento, e você tem que ter o conhecimento como é o manual desses equipamento, como é que você vai fazer uma leitura do manual de equipamento que você vai usar se você não sabe ler?

(2) No caso, hoje eu estou como presidente, sei ler, sei escrever e tal. Amanhã ou depois, qualquer outro cooperado que tá aqui dentro pode ser um presidente, e como é que ele vai ser presidente se ele não sabe assinar os documentos que precisa ser assinado? Assinar uma folha de cheque pra fazer o pagamento dos cooperados, tudo isso... Pra fazer a assinatura num projeto de uma parceria, de um convênio com a Prefeitura, com o Ministério Público, tudo isso a gente tem que saber ler. Você lê o instrumento lá, que antes de assinar você lê, tem o conhecimento. Hoje, na verdade você tá tratando com pessoas do poder público e tudo, mas nem tudo a gente deve expressar uma confiança total naquilo que tá escrito no papel. Estar ciente realmente, ler um pouco antes de assinar, ter o conhecimento realmente. Ah, não, eu tô ciente do que que tá acontecendo, então eu posso assinar sabendo o que eu tô assinando.

(3) Se os companheiro não tiver um incentivo pra buscar se alfabetizar, pra se formar, pra se capacitar... Hoje a gente já tem até satisfação de falar. Tem uma catadora lá em Anápolis que ela trabalhava no lixão e estudava. Aí ela saiu do lixão, tá na cooperativa, continua a estudar, se formou agora no começo desse ano. Não me recordo bem a matéria, agora já tá fazendo a faculdade.

A escolarização dos catadores é da maior importância para que possam se afirmar como profissão, defendendo seus interesses e participando como atores ativos no processo. $\mathrm{O}$ socioambientalismo tem a emancipação como objetivo a ser alcançado por meio da EA crítica e essa emancipação ocorre quando os sujeitos se tornam agentes do processo, elaborando, 
pensando, definindo e se organizando com autonomia, sem depender de agentes públicos ou instituições para isso. Seu $\operatorname{Iramar}^{14}$ conta o que viveu

(4) Isso lá na favela ainda. Foi, lá na favela. Aí com essa entidade já registrada e legalizada, nos empoderou mais ainda no processo de organização. O poder público nos enxergou diferentes, que estávamos realmente querendo nos organizar, que era pai de família que estava querendo um direito e dignidade de trabalhar, se fosse reconhecido pelo poder público e pela sociedade.

Sabemos que a educação é carregada de intencionalidades, portanto, a escolarização dos catadores é um terreno de problemática complexa. De um lado, existe a difícil luta dos catadores buscando afirmar-se e construir uma identidade. De outro, a força de uma educação que se diz emancipatória, mas que quando carregada de cunho puramente ideológico, retira a força dos catadores, colocando-a nas instâncias educadoras, ou seja, os sujeitos educandos passam a acreditar e a depender do poder da instituição educadora. Contudo, à instância educadora verdadeiramente emancipadora compete interagir de maneira a contribuir para a formação de sujeitos cooperativos e participativos, surgindo daí a distinção entre empoderamento e empoderar-se. Um é conduzido, enquanto o último é conquistado a partir da própria capacidade de reflexão do grupo. Tassara et al (2014, p.160) procuram mostrar essa distinção dizendo que "empoderar-se significaria ser capaz de conduzir decisões sob a ótica do bem comum, assentada sobre processos reflexivos alimentando os espaços de locução emancipatórios." Sobre o empoderar-se, esses autores esclarecem ainda que

Ou seja, para propiciar o empoderar-se, a instância socializadora deve interagir de maneira a contribuir para a formação de sujeitos cooperativos e participativos, capazes de fundamentar suas ações em uma ética do bem comum, assentando seus juízos, reflexiva e racionalmente, em ideais democráticos de justiça, solidariedade e respeito à diversidade de valores. Se estas interações entre a instância socializadora e demais atores em processo de funcionamento grupal produzir tais resultados, pode-se afirmar que o mesmo constituiu-se em um espaço de locução. (TASSARA; TASSARA; ARDANS, 2014, p.159)

É nesse espaço complexo de múltiplos desafios e tensões que esta pesquisa transita com as estratégias da EA. Porquanto a complexidade que desponta desse espaço é a mesma que está na natureza da EA, um lugar em que os sujeitos envolvidos poderão se perceber em

\footnotetext{
${ }^{14}$ Entrevista no 3 , de 16/04/2015
} 
um ambiente onde a interlocução entre "sua ontologia (sua existência como ser) e sua epistemologia (o conhecimento que se pode ter sobre ele) coincidem." (TASSARA et al, 2014, p. 159) Esta pesquisa realizada, embasada nos princípios da pesquisa-ação e da pesquisa participante, almeja fazer uma interconexão entre a EA e a EP, mesmo sabendo que as tensões não se desfazem, mas localizando elos entre a EA e a EP nesse espaço de lutas dos catadores.

\subsection{As cooperativas de resíduos sólidos de Goiânia: um espaço de interlocução no curso das águas entre a Educação Popular e a Educação Ambiental}

O lixo é o gerador da coleta seletiva e para falar da coleta seletiva é preciso entender o lixo, pois a coleta seletiva é uma decorrência da produção de lixo. O lixo é um fenômeno puramente humano, na natureza não existe lixo, na natureza tudo tem vida e tudo se renova, lembrando Lavoisier, dos meus tempos de estudante de escola fundamental. Em sua caminhada "evolutiva" o homem priorizou a capacidade inventiva em busca de atender as suas necessidades de sobrevivência junto à natureza e, assim, foi destruindo a natureza, na medida em que ia inventando formas de se proteger e se alimentar. Mas a capacidade inventiva da humanidade não se contentou somente em proteger-se e alimentar-se, o homem logo viu que podia acumular, viu que acumulando podia vender e lucrar.

O comércio, que se alimenta pelo grande estímulo ao consumo, ao mesmo tempo em que depreda desenfreadamente a natureza, provocou e provoca um grande acúmulo de lixo produzido pela sociedade humana. Para acomodar esse lixo, a sociedade os despeja em lixões a céu aberto, mas o acúmulo imenso exigiu um tratamento. Então, inventou os aterros sanitários, que passam a conviver com os lixões. Estes, não suportando mais o grande volume de lixo que recebem, obrigam a sociedade a olhar para o lixo que produz. As pessoas começam, então, a perceber que nem tudo é lixo, a se dar conta da presença da natureza no lixo produzido, a compreender que a natureza tem um ciclo de renovação e, até mesmo, entender que fazem parte da natureza. Assim, a humanidade é impelida a iniciar a coleta seletiva. Sua capacidade inventiva, aliada à sua ganância, a levou à destruição da natureza, desrespeitando os ciclos, devastando a vida. Arendt (2008, p. 107-108) nos faz lembrar que todas as coisas possuem um processo de vida e que nós somos parte de um processo natural onde tudo possui um ciclo, possui um momento de permanência e um retorno ao processo natural: 
Das coisas tangíveis, as menos duráveis são aquelas necessárias ao próprio processo da vida. Seu consumo mal sobrevive ao ato de sua produção; no dizer de Locke, todas essas <boas coisas $>$ que são $<$ realmente úteis à vida do homem>, à <necessidade de subsistir>, são < geralmente de curta duração, de tal modo que - se não forem consumidas pelo uso - deteriorar-se-ão e perecerão por si mesmas >. Após breve permanência neste mundo, retornam ao processo natural que as produziu, seja através de absorção no processo vital do animal humano, seja através da decomposição; e, sob a forma que lhes dá o homem, através da qual adquirem lugar efêmero no mundo das coisas feitas pela mão do homem, desaparecem mais rapidamente que qualquer outra parcela do mundo. Consideradas em sua mundanidade, são as coisas menos mundanas e ao mesmo tempo as mais naturais. Embora feitas pelo homem, vêm e vão, são produzidas e consumidas de acordo com o eterno movimento cíclico da natureza. Cíclico, também, é o movimento do organismo vivo, sem exclusão do corpo humano, enquanto ele pode suportar o processo que permeia o seu ser e o torna vivo. A vida é um processo que, em tudo, consome a durabilidade, desgasta-a, fá-la desaparecer, até que a matéria morta, resultado de pequenos processos vitais, singulares e cíclicos, retorna ao círculo global e gigantesco da própria natureza, onde não existe começo nem fim e onde todas as coisas naturais circulam em imutável, infindável repetição.

A lógica de produção e consumo inventada pelo homem é geradora de produtos que, embora tenham sua origem na natureza, a manipulação humana dificulta o seu retorno ao ciclo natural. Nessa artificialidade, a indústria e o comércio tentam inventar seu próprio ciclo, mas que se confronta com o grande ciclo natural da vida. O maior desafio, então, passa a ser, encontrar um equilíbrio nesse amplo circuito que envolve a vida.

A coleta seletiva, portanto, é um artifício que nasce da necessidade de cuidar do mais pernicioso produto do mundo artificial criado pela humanidade, o lixo. Ela se torna, então, uma conciliação de forças entre o mundo artificial e os ciclos da natureza, conectando-se paradoxalmente aos catadores pelas vias das desigualdades sociais. Possuindo um ciclo próprio ela antecede os programas e as leis, impulsionada, por um lado, pela grande produção de resíduos pela sociedade e, por outro, pela significativa demanda de pessoas excluídas da relação de consumo, que se consomem retirando daí o seu sustento. Em Goiânia, o movimento dos catadores antecedeu e pressionou a coleta seletiva na cidade. Em entrevista concedida para esta pesquisa, Seu Iramar ${ }^{15}$ conta um pouco dessa história.

(5) Tive o conhecimento e a concepção dessa realidade, que haveria a importância de nos organizar como associação ou como uma cooperativa, já que a gente trabalhava como catadores de materiais nas ruas, né, puxava carrinho, morava na favela. Aí a gente teve conhecimento do movimento

\footnotetext{
${ }^{15}$ Entrevista n ${ }^{\text {o }}$, de 16/04/2015
} 
nacional dos catadores, que é uma ferramenta política, que traz o conhecimento e a troca de experiência de vários catadores a nível de Brasil. Hoje eu faço parte desse movimento, sou o representante do movimento nacional dos catadores no Estado de Goiás e sou um dos membros da Comissão Nacional.

(6) Com esse conhecimento do movimento foi aonde despertou a ideia de organizar a comunidade onde nós morávamos - uma favela que ficava na Vila Nova, bem ao lado da Pecuária. Passamos a fazer o registro da cooperativa, fazendo ata, estatuto, né, a gente conseguiu organizar juridicamente o documento da cooperativa, mas a gente não tinha área e não tinha casa pra morar. E aí, desde então, com esse instrumento na mão, que era a cooperativa, a gente começou a articular com a Prefeitura, e a Prefeitura não tinha projeto de coleta seletiva, e aí a gente começou a trabalhar nas ruas, conscientizando alguns prédios e condomínios pra separar o material que nós passaríamos a coletar. Aí a gente começou a fazer a coleta seletiva muito antes do projeto da Prefeitura. (...) Isso foi no começo de 2000, a gente já começou a se organizar quanto à associação.

Em 2008, tem início em Goiânia o Programa Goiânia Coleta Seletiva (PGCS), criado pela prefeitura, que, como vimos, surge a reboque das forças e movimentos sociais que exigiam que o poder público tomasse alguma providência para reparar essa situação que já se apresentava envolvida em dimensões imensuráveis. Assim, nasce esse Programa em Goiânia “com o objetivo de evitar que materiais recicláveis fossem para o aterro sanitário, podendo assim aumentar a vida útil deste e, ao mesmo tempo, beneficiar famílias em cooperativas de catadores." (GOIÂNIA, 2008) A coleta seletiva foi instituída inicialmente somente em dez bairros da cidade e em alguns Pontos de Entrega Voluntária, os chamados PEVs. A partir de 2009, tem início a coleta de porta em porta, com a ampliação da coleta a cada ano. Atualmente, a COMURG informa estar fazendo a coleta em toda a capital, mais de 500 bairros, com um calendário de coleta para cada bairro. O que se sabe, como habitante dessa cidade, é que essa coleta não tem sido feita a contento, além de passar somente uma vez por semana, há semana que o caminhão não passa; em outras, passa, mas não pára em todas as portas.

Essa coleta se dá em caminhão apropriado para essa finalidade e em cronograma distinto do recolhimento do resíduo orgânico. Os resíduos sólidos arrecadados são distribuídos em cooperativas instaladas nas periferias da cidade, algumas circundadas por comunidades que têm aí o seu principal sustento. Até 2014, existiam 15 cooperativas cadastradas na prefeitura da cidade de Goiânia e, dentre estas, 7 fomentadas pela Incubadora Social da Universidade Federal de Goiás (UFG), ligada à Pró-Reitoria de Extensão e Cultura (PROEC). Essas cooperativas concentram muitas pessoas e vivem em torno do trabalho de 
triagem e venda do material reciclável ${ }^{16}$. A quantidade de catadores em cada uma está sempre variando, porque dificilmente se mantêm por um longo período nessa atividade, mas cada cooperativa trabalha com uma média de 15 a 20 pessoas.

A estrutura para receber os resíduos varia em cada cooperativa. Na maioria das vezes a coleta trazida pelos caminhões é depositada nos pátios onde, no chão mesmo ou sobre bancadas e com pouca proteção de equipamentos, é feita a triagem. Muitas funcionam em condições precárias de higiene e estrutura. $\mathrm{O}$ trabalho realizado é basicamente o de triagem e armazenamento dos resíduos em grandes sacos de lona, que eles denominam de "bags", fornecidos pelas empresas, as mesmas que retornam para negociar e transportar o material separado. Esses "bags" possuem um tamanho padronizado e servem de unidade de medida. Segundo a presidente da cooperativa Coocamare, o valor do material vendido é determinado pelo mercado, ou seja, a cooperativa vende para quem pagar mais. O dinheiro arrecadado é dividido entre os catadores envolvidos, sob a administração de uma liderança escolhida pelo grupo, conforme os preceitos das cooperativas autogestionárias.

O Programa Goiânia Coleta Seletiva (PGCS) percebe a necessidade de fazer a capacitação dos catadores para que eles consigam se organizar e administrar suas associações. A UFG, então, é convidada a prestar essa assessoria. Dessa parceria nasce em 2008 a Incubadora Social da Universidade Federal de Goiás, vinculada à Pró-Reitoria de Extensão e Cultura, com a finalidade de fazer a capacitação e o assessoramento aos empreendimentos dos catadores de materiais recicláveis. Essa Incubadora iniciou imediatamente o atendimento a três associações, mas, impelida pela grande demanda, ampliou rapidamente seu atendimento e em 2011 já estava com 10 grupos sendo atendidos. A adesão desses grupos à Incubadora é voluntária, as cooperativas incubadas é que definem quanto à sua adesão, permanência e saída do vínculo com a Incubadora. Por essa razão, em 2014 havia 7 cooperativas incubadas. A Cooperfam, a CooperMas, a Cooper Rama, a Guarani, a Cooprec, a Coocamare e a Acop.

Essas foram as cooperativas que eu percorri no período de construção do campo desta pesquisa, com um instrumento de coleta de dados para fazer o levantamento da demanda dos adultos que não sabiam ler e escrever em cada uma delas e conhecer um pouco do perfil desses sujeitos. Com esse procedimento, localizei 30 adultos catadores que não sabiam ler e escrever e que demonstraram interesse em frequentar uma turma que fosse específica para

\footnotetext{
${ }^{16}$ Reciclagem, lei $n^{\circ} 12.305$, de 2 de agosto de 2010, item XV, Capítulo II, é o processo de transformação dos resíduos sólidos que envolve a alteração de suas propriedades físicas, físico-químicas ou biológicas, com vistas à transformação em insumos ou novos produtos, observadas as condições e os padrões estabelecidos pelos órgãos competentes (...).
} 
eles. Esse foi um período importante para a pesquisa que realizei, pois, além da coleta de dados, foi, na verdade, o caminho por onde iniciei a pesquisa, a partir do dia 15 de outubro de 2013, um momento importante de minha aproximação ao mundo dos catadores por meio do qual as visitas suscitavam os vínculos humanos mais até do que o conjunto de dados apurados.

A Lei $n^{\circ} 12.305$ que legisla sobre a Política Nacional de Resíduos Sólidos (PNRS), sancionada em 02 de agosto de 2010, dava prazo de 4 anos para que as cidades se adequassem às normas dessa política. Para isso, todos os municípios do país teriam que substituir os lixões por aterros sanitários, implantar a coleta seletiva e a reciclagem, o reuso, a compostagem e o tratamento do lixo até 2014. Com essa exigência, a Incubadora da UFG precisou ampliar sua área de atendimento para outros municípios além da região metropolitana de Goiânia, com parcerias via Secretaria Nacional de Economia Solidária (SENAES) e com o Ministério Público do Estado de Goiás.

Com relação a esse prazo estabelecido pela PNRS, muitos municípios alegaram não terem condições de atender as exigências no prazo estabelecido. Em decorrência, no dia 01/07/2015, o Senado aprovou um projeto que prorrogou o prazo para as cidades brasileiras se adequarem às regras da PNRS. De acordo com esse projeto aprovado, os municípios têm o prazo de 2018 a 2021 para se adequarem à PNRS, com critérios que variam de acordo com a localização geográfica, o número de habitantes e a renda. Quanto maior o município e a renda, assim como os de fronteira, menor o prazo. Sobre o empenho dos municípios, o Sr. Fernando, coordenador da Incubadora Social da UFG, em entrevista ${ }^{17}$ para esta pesquisa, comenta:

(7) Eu acho que está como quase todos os lugares que eu conheço, muito fraco, muito tímido, mas isso a gente tem detectado aqui no decorrer do tempo que existe o que a gente chama de "a cultura do lixo", nós vivemos sob a cultura do lixo e nós temos percebido que tanto a sociedade e os governantes percebem os materiais que são descartados, não importa se é reciclável ou não, isso é lixo. [..]) Então, a gente vê governantes de municípios que não se preocupam em fazer essa distinção entre o que é material reciclável ou não, para que as pessoas possam compreender que o material reciclável não é lixo, é material limpo, é material gerador de trabalho e renda. Essa eu creio que é a maior das dificuldades por estarmos submetidos a cultura do lixo. Então, investir nesse segmento não é uma coisa que está dentro dos planos, desde que tirou da frente da casa, sumiu, já resolveu o problema.

\footnotetext{
${ }^{17}$ Entrevista $^{\circ} 1$, de $05 / 03 / 2015$
} 
(8) Então nós percebemos que é muito comum, a gente observa, isso é visível, por exemplo, o investimento em propaganda dos governos muito maior do que em uma estrutura dessa natureza. Então, no meu entender, que eu vejo essa relação entre Educação Ambiental e Coleta Seletiva, [...] acho que o ponto de partida é a educação ambiental, mas ela de certa forma orientada para quebrar esse paradigma que vem amarrado nesse aí chamado de cultura do lixo, esse é o grande problema que nós vivemos aí.

Esse comentário do Sr. Fernando esclarece que a prorrogação do prazo dado aos municípios para o cumprimento da Lei de PNRS, não resolve a situação, porque se o prefeito não tiver consciência ambiental ele nunca vai conseguir cumprir o que está estabelecido nessa diretriz, ou em qualquer outra, não importa qual seja o prazo. O problema não está na Lei ou nos prazos, o problema está na falta de Educação Ambiental, no analfabetismo ambiental dos governantes. A PNRS não se integra à visão estreita de muitos governantes submergidos em suas astuciosas políticas eleitoreiras. Essa tem sido uma grande dificuldade encontrada no trabalho da Incubadora e é também uma grande barreira para o avanço do trabalho ambiental. A Incubadora está no meio de uma cadeia, tentando fazer o elo entre as partes que a mantêm.

Cada cooperativa visitada possui uma história e em cada história uma gota a mais que se desprende das narrativas ocultadas nas sombras das águas de nossa sociedade. As cooperativas que visitei trazem de comum entre elas um grupo de pessoas que experimentam o espaço mais dolorido da nossa sociedade, pessoas que sabem o que é a fome pra além do intervalo entre uma refeição e outra. Pessoas espectadoras do mundo consumista e que se consomem na lida com os resíduos sólidos, mas pessoas cujas águas permanecem aquecidas pelo calor de suas emoções, na partilha da vida, no cultivo coletivo dos sonhos. Dentre estas, destaco a cooperativa Cooprec e a Acop, por serem pioneiras nesta experiência em Goiânia e guardarem memórias de uma relevante história da experiência da EA vivida nesta cidade.

A cooperativa Acop e a Cooprec são as grandes pioneiras na experiência da coleta seletiva em Goiânia. Elas viveram essa experiência de maneira diferente, a partir do contexto de cada uma. A Cooprec era composta por pessoas que moravam nos bairros do seu entorno, cada uma tendo o seu lugar de moradia nesses bairros, ou nas proximidades e trabalhavam nos serviços da cidade: domésticas, babás, serviços gerais, ajudantes de pedreiro e até catadores, dentre outros. A Acop era composta por pessoas que não tinham onde morar, elas moravam em uma favela debaixo de uma ponte, sobre os trilhos de trem de uma linha desativada. Pessoas que viviam da coleta de material reciclável, andando pelas ruas, puxando os seus carrinhos, como meio de sobrevivência. A cooperativa foi uma maneira de se organizarem para lutarem também por moradia. A diferença fundamental entre essas duas histórias é que 
uma cooperativa foi entregue pronta, equipada, estimulando um grupo a tornar-se catador, enquanto a outra foi fruto da luta de quem era catador, mesmo sem ter uma cooperativa.

No início do ano de $2013 \mathrm{fiz}$, por telefone, o primeiro contato com a Incubadora Social da UFG, quando soube de seu trabalho junto às cooperativas, a fim de buscar essa parceria para a realização da pesquisa. Eu já estava fazendo o Doutorado na UnB. Nesse contato, conversei com o Sr. Fernando, coordenador da incubadora, a quem me apresentei e comentei acerca da pesquisa que intencionava realizar. Ele se mostrou muito interessado pelo meu trabalho e se dispôs a colaborar de toda maneira que fosse possível, pois alfabetizar os catadores fazia parte dos objetivos da incubadora, embora não estivesse sendo possível materializar esse objetivo. Um dos meus primeiros contatos pessoais junto à Incubadora está registrado na memória de uma reunião com um bolsista da Incubadora. Essa memória, resgatada do diário de campo, é um registro das mudanças de rumo que foram se sucedendo, pois as estratégias para a formação da turma, que definimos nessa reunião, foram inteiramente modificadas.

Reunião com bolsista que atua na incubadora, com suporte em gestão das cooperativas - dia 15/10/2013 - 15 horas - sob a sombra das mangueiras da Incubadora Social - PROEC UFG.

Expliquei para o bolsista acerca de que consistia a pesquisa que intencionava realizar. Depois, discutimos estratégias para a organização de turmas de alfabetização de adultos. A ideia era podermos agrupar as cooperativas por região, a fim de conseguirmos o número mínimo de inscritos, 15 alunos para a formação de turma, conforme as diretrizes do AJA- Expansão. Assim, o bolsista sugeriu agrupar as cooperativas pela proximidade geográfica pensando em facilitar o deslocamento dos educandos para um local onde a turma estivesse instalada. Montamos três agrupamentos:

Agrupamento I:

CooperMas, Cooperfame e Carrossel(não incubada)

Ficam próximas e se localizam na região do Jardim Vera Cruz

Agrupamento II:

Acop, Carrinho de Ouro(não incubada) e Cooper Rama

Ficam próximas e estão na região do Curitiba

Agrupamento III:

Coocamare, Ambiental(não incubada), Beija Flor(não incubada) e Guarani Ficam próximas e estão na região da UFG e Crimeia Oeste

Hoje, este registro é sobretudo uma expressão do meu distanciamento a essa realidade naqueles momentos iniciais. Aos poucos, fui aprendendo que os planejamentos precisavam ser feitos a cada dia, a partir de cada situação encontrada. A primeira mudança de plano foi devido à dificuldade de acesso às cooperativas não incubadas. Soube que elas possuem uma relação patronal muito rígida que dificulta o contato com os catadores, pois eles têm metas e horários estabelecidos para cumprir. Então, decidi envolver somente as cooperativas incubadas, nessas não havia dificuldade para o acesso à cooperativa e aos catadores. 
Considerei que, para a realização da pesquisa, somente as cooperativas incubadas seriam suficientes para responder às questões, não havendo necessidade de entrar no espaço das cooperativas patronais que, na verdade, nem trabalham em regime de autogestão. Segundo informação do bolsista, os catadores são contratados com remuneração fixa estabelecida e o presidente é, na verdade, o patrão. Logo entendi que há nesse espaço muito o que ser investigado, mas que isso é demanda para outras pesquisas.

A partir de outubro de 2013, iniciei as visitas pessoais às cooperativas, acompanhando bolsistas da incubadora, para me aproximar dessa realidade e fazer um levantamento da demanda, pois o Programa AJA-Expansão exigia no mínimo 15 alunos para formar uma turma. Iniciei os primeiros contatos com os catadores junto com os bolsistas da Incubadora, pois era difícil fazer agendamento sem que eles soubessem do que se tratava e como não dava para explicar por telefone, eu precisava me apresentar pessoalmente aos catadores. Após as primeiras visitas, percebi que para ter um levantamento acerca da demanda do analfabetismo entre os catadores das cooperativas incubadas eu precisaria elaborar um instrumento de coleta de dados e percebi, também, que seria mais ágil fazer o primeiro contato me apresentando e em seguida respondendo o questionário.

O coordenador da Incubadora já me havia informado acerca da demanda do analfabetismo junto aos catadores me apresentando as assinaturas, algumas com digitais e outras feitas por memorização, em documentos da Incubadora. Foi bom ter essa informação, mesmo assim considerei necessário fazer um levantamento para buscar informações mais aproximadas da realidade. Afinal, precisava buscar as informações para a pesquisa que eu estava fazendo. Elaborei um instrumento de coleta de dados e continuei as visitas às cooperativas. Agendava essas visitas às vezes aproveitando agendamentos que os bolsistas já tinham, outras vezes eles me acompanharam em retornos para coleta de dados agendados por mim mesma, e outras vezes fui sozinha.

Foram ao todo 8 cooperativas visitadas por mim: CooperMas, Cooperfam, Acop, Cooper Rama, Coocamare e Guarani. Visitei também uma cooperativa denominada Nossa Senhora Auxiliadora, mas referida apenas como Auxiliadora, que teve um período breve de existência e não resistiu às dificuldades provenientes de uma greve da coleta seletiva na cidade. Segundo o presidente me informou, estava dando prejuízo, porque tinham que pagar o aluguel do galpão e o que arrecadavam não estava dando para a sobrevivência dos catadores. No início de 2014, visitei a cooperativa Cooprec, uma das mais antigas da cidade, que decidiu se filiar à Incubadora, ficando 7 cooperativas incubadas. 
A cada visita realizada me aproximava um pouco mais da vida dos catadores e das cooperativas. Aos poucos, fui percebendo o movimento constante que há nesse ambiente, um fluxo impelido pela sobrevivência, que ora aproxima os catadores, ora os afasta das cooperativas. Ora é interessante vincular-se à Incubadora, ora não, orientando-se pela melhor maneira de aumentar a renda. Assim, percebi que a impermanência domina os ambientes das cooperativas. O levantamento dos dados foi muito importante, pois além da confirmação da demanda para a formação da turma, obtive um perfil desses sujeitos. O próximo passo foi a formação da turma.

Foram 93 questionários respondidos, aproximadamente $80 \%$ do total dos catadores das 7 cooperativas visitadas, sendo 34 homens e 59 mulheres, com média de idade de 40 anos. O estado civil apresentou 20 casados, 6 separados, 21 vivendo com o companheiro, 4 viúvos e 36 solteiros. Uma média de três filhos. A maioria, 54 catadores, se identificou de cor parda, 11 branca, 21 preta, 1 amarela, 1 indígena e o restante não quis identificar essa informação. $O$ transporte que utilizam para chegar nas cooperativas demonstrou que a maioria mora nas proximidades das cooperativas onde trabalham, pois, dentre os que informaram, 43 vão a pé, 27 de transporte público, 4 de motocicleta, 5 de bicicleta, 2 de carro e 5 moram nas cooperativas. A renda mensal apresentada foi de 51 catadores até 1 salário mínimo, 36 de 1 a 3 salários mínimos, 1 de 3 a 5 salários mínimos. O rendimento da cooperativa às vezes é maior que um salário mínimo, mas o mais comum é ser menor que um salário. Os que têm renda maior trabalham em outro lugar também, ou tem imóvel alugado. A maioria mora em residência própria, 44 catadores. 30 moram de aluguel e 17 moram em outras condições: com os pais ou parentes ou na própria cooperativa.

A escolaridade mostrou 21 não alfabetizados e 11 alfabetizados, 30 com o ensino fundamental incompleto, 09 com ensino fundamental completo, $10 \mathrm{com}$ ensino médio incompleto, 11 com ensino médio completo e uma catadora com o superior completo, formada em administração, trabalhando na administração de uma cooperativa. O número dos não alfabetizados aumentou para 30 quando retornei às duas cooperativas que iam participar da pesquisa, para fazer o cadastro para a formação da turma. Dos 93 que responderam o questionário, 10 estavam estudando e 83 sem estudar. Esses dados confirmaram informações estatísticas já anunciadas, como o grande número de pessoas sem estudar, sem completar o fundamental, a redução no ensino médio e no superior, mas foram importantes para a definição da pesquisa, especialmente, por confirmarem a demanda de catadores que não sabiam ler e escrever, por me mostrarem a localização de todos eles e nos mostrar que o que 
as estatísticas apresentam é uma realidade concreta, localizada e com desejo de que algo possa ser feito para modificá-la.

Além dessas informações indaguei também sobre que outras habilidades artísticas ou profissionais eles possuíam, além da atividade de catador, e obtive a informação atualizada de um diversificado contexto que envolve as nossas realidades. Eles informaram diversas habilidades como: servente; crochê; artesão; fazer tapete: de tear, de crochê, de retalhos; serralheria; moveleiro; mistura de plástico na fábrica; feirante; dona de casa; manicure; pedreiro; faz pintura em textura e grafiato; atividade rural; motorista; toca teclado e canta; baterista de banda; operador de trator; auxiliar de contabilidade; telefonia; digitação; artesanato com reciclável; curso de cooperativismo; auxiliar administrativa escolar; carpinteiro; garimpeiro; cozinheiro; dança forró; limpa quintal; cuida de idoso; diarista; vendedor; joga futebol; desenha; costureira; auxiliar de costura; doméstica; auxiliar de limpeza; cabeleireira; serviço braçal; cuidar de gado. Ao ver esses dados, imaginei a riqueza de uma turma formada com essas pessoas, quantos saberes partilhados, um autêntico contexto transdisciplinar e revelador de um mundo ocultado pelas sombras da sociedade.

O que você deseja como trabalhador de cooperativa de reciclagem, foi outra questão que apresentei, intencionando verificar o vínculo à profissão de catador e as respostas expressaram o desejo de prosperar na cooperativa, como catador. O reconhecimento do trabalho; qualidade de vida, de moradia e de formação (faculdade para catadores); organizar financeiramente a cooperativa; ajudar na formação dos cooperados a ser dono do próprio negócio; ser objetivo em tudo; poder melhorar a renda; ter boa renda; organização da cooperativa; muito respeito; grandes vitórias; que a cooperativa alcance o sucesso. A última questão que lhes apresentei queria saber qual o grande sonho na vida, à qual eles disseram: ganhar a casa onde está inscrito há 5 anos; ter a casa própria; concluir a faculdade; ter o próprio negócio; acabar com as drogas; ser feliz; formar em Direito; melhorar a saúde; terminar os estudos; ser policial; crescer profissionalmente; educar os filhos para ser alguém na vida.

CooperMas: Cooperativa dos Catadores de Materiais Recicláveis "Meio Ambiente Saudável" - foi a primeira cooperativa visitada, localizada na Avenida Senador Canedo n³1, no Setor Conjunto Vera Cruz I, no dia 11 de novembro de 2013. Foi meu primeiro contato com essa cooperativa e com o conjunto de cooperativas que teria de percorrer. Estava acompanhando um bolsista da Incubadora, ele tinha um agendamento marcado para discutir questões de gestão. Fomos recebidos pela presidente. O bolsista me apresentou a ela e explicou rapidamente do que se tratava. Ela enviou recado por um catador, a notícia se 
espalhou e logo estavam em frente à casa sede da cooperativa, improvisando lugar pra sentar. Demonstraram estar habituados a se reunirem ali. Havia 15 catadores na cooperativa e, após explicações do bolsista, continuei a reunião com 13 catadores, 2 decidiram voltar ao trabalho. Nesse contato, expliquei sobre a turma, como seria feito o trabalho, a quem se destinava. Queria saber qual o interesse e se tinha alguém com vontade de participar. Havia 2 catadores com o ensino médio, pensei no educador popular, mas não consegui saber ao certo acerca da demanda de alfabetizandos e escolarização dos demais. Combinei de retornar a essa cooperativa para aplicar o questionário, pois foi a partir desse encontro que ficou bem claro que eu precisava aplicar um questionário para a coleta de dados mais precisos sobre a escolarização desses catadores.

Dia 20 de dezembro de 2013, com agendamento feito, retornei à CooperMas para fazer a coleta de dados com o questionário. Cheguei pela manhã, por volta das $10 \mathrm{~h}$. Fui conversando com os catadores de um por um, para coletar os dados para não interromper o trabalho da cooperativa. Foi mais demorado, mas foi essa a condição apresentada pela presidente e acatada por mim, assim eles me atendiam sem precisar interromper o serviço. Chegou a hora do almoço e eu ainda não havia terminado. A presidente fez o almoço e me convidou, almocei junto com eles. Uma comida goiana bem simples e muito saborosa: arroz, feijão, um picadinho de carne ao molho, macarrão e salada de tomate com repolho picadinho. Quando todos se reuniram, ela foi servindo a comida em cada prato. Com a minha presença, teve conversa sobre a vida escolar de cada um e outros assuntos, durante o almoço. Uma catadora, filha da presidente, havia buscado a filha na escola para almoçar ali. Após o almoço, a menina foi pra casa com uma acompanhante. Cada um lavou suas vasilhas, eu também. Durante a sesta do almoço consegui finalizar o levantamento com 11 questionários respondidos. O levantamento apontou 4 catadores alfabetizandos e 3 não quiseram responder que, segundo eu soube, eram alfabetizandos.

A CooperMas está instalada em uma área de aproximadamente 5.000 metros quadrados. Toda cercada com um muro pré-moldado. Possui 3 galpões: dois onde organizam as atividades de triagem dos resíduos e um, bem alto, com uma grande prensa. Há também uma casa sede pequena, com uma varandinha, onde almoçamos, e nela tem uma geladeira, um pequeno banheiro com chuveiro, pia e sanitário e a entrada da cozinha. Contígua à cozinha, mas com entrada separada, por fora, há uma sala do escritório com computador e internet. A presidente ofereceu esse espaço para instalar a turma. Vi que seria possível para uma turma pequena com até 6 alunos. O material da reciclagem não era colocado no espaço da casa que, embora pequeno, pareceu ter organização e asseio. Não havia nenhuma árvore. É uma região 
alta e da parte mais alta do pátio uma ampla e bonita vista da linha do horizonte distante, do encontro entre o céu e a Terra. Uma paisagem repousante, extinta na urbanidade. O meu olhar arqueado me situava no espaço entre aqueles resíduos e a infinitude, até de mim mesma.

Figura 18 - Linha do horizonte

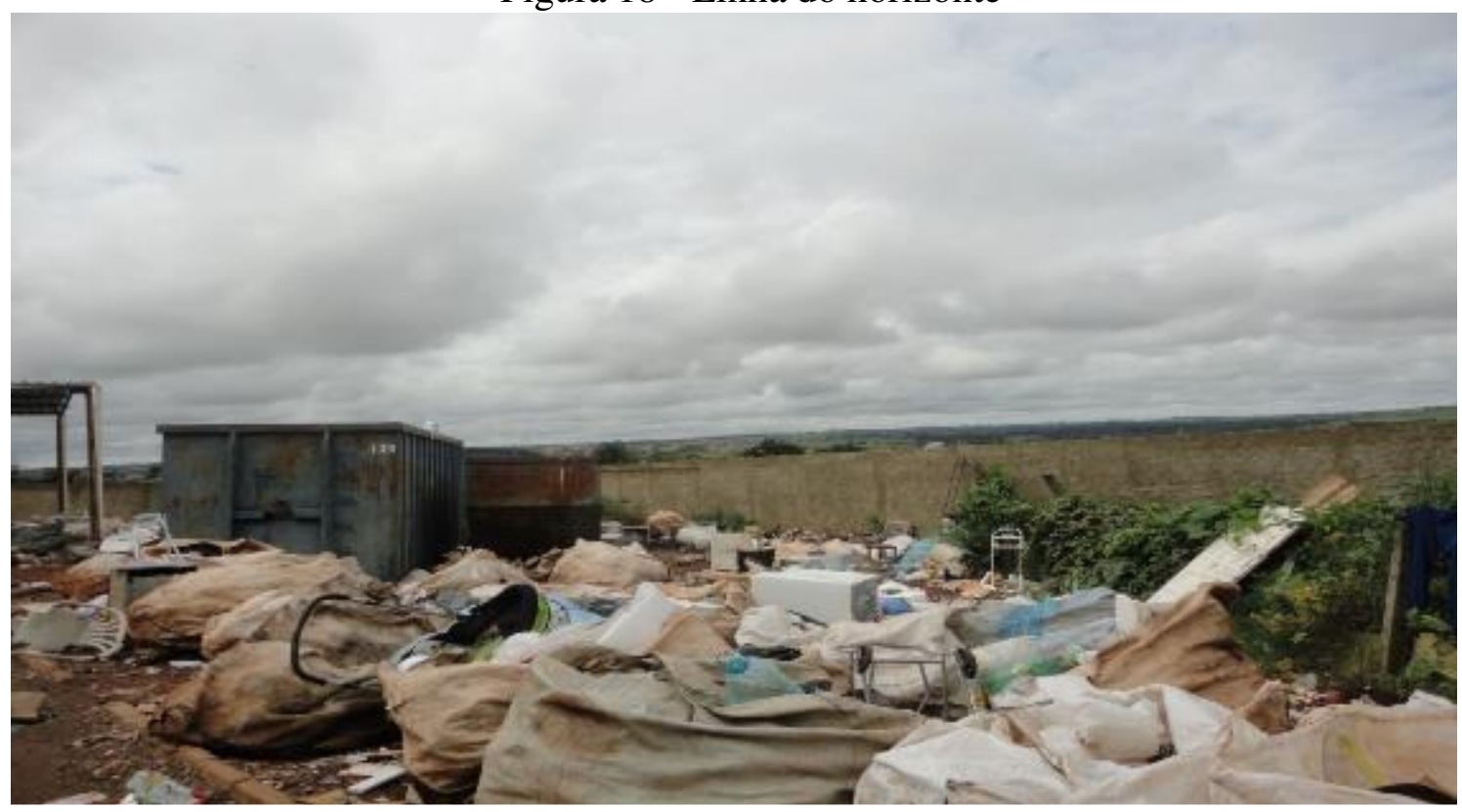

Fonte: acervo da pesquisa. Pátio da CooperMas. Ano: 2013.

Coocamare: Cooperativa dos Catadores de Material Reciclável - foi a segunda cooperativa que visitei. A primeira visita foi no dia 26 de novembro, para me apresentar à presidente e conversar sobre o meu projeto de alfabetização, e outra no dia 19/12/2013, para responderem o questionário. Essa cooperativa estava instalada em uma chácara, alugada, próxima ao Campus II da UFG, localizada na Rua 03, S/N, lotes 12-13, no bairro Chácara Retiro. Era cercada com muro pré-moldado, havia um portão de entrada e saída de pessoas e veículos, que estava sempre aberto, por onde eu entrava e estacionava o carro próximo à casa sede. Do seu lado ficava outra cooperativa que não era incubada e me disseram que era muito difícil conversar com a presidente, ela não era de muita conversa, e todos tinham que cumprir o horário com rigor.

O pátio da Coocamare chamava a atenção pelas frondosas mangueiras carregadas de flores e frutos, servindo de abrigo para o trabalho dos catadores. A presidente contou que o dono da chácara se empenhava em preservar essas árvores, que ele deixou de alugar mais caro para uma empresa de ônibus porque teria que derrubá-las. Essa cooperativa não possuía galpão, nela havia duas grandes tendas armadas que abrigava, em uma, parte do material e, 
em outra, uma máquina de prensar. O material era depositado dos caminhões diretamente no pátio, sob as mangueiras. As copas frondosas carregadas de flor e fruto, derreadas sobre os resíduos, era a natureza com seus braços abertos, frondosos e férteis acolhendo amorosamente aquele fruto desgarrado que retornava ao colo aquecido da mãe.

Do lado esquerdo da entrada havia um cercadinho, de alambrado, caindo abandonado, com mato crescendo, indicando que ali houve uma horta. Havia galinhas com pintinhos mariscando soltos nessa parte da frente à esquerda, porque do outro lado e mais ao fundo era onde trabalhavam, em volta da casa. Havia uma casa simples, de telhado de barro, baixo, com estilo de casa de campo. Indicava que aquela já havia sido uma região de fazenda, onde hoje é área urbana. Era volteada por uma varanda estreita onde estava a entrada principal, na frente, e outra pela parte lateral à esquerda. A entrada da frente dava para uma sala onde estava instalado o escritório da cooperativa, com um computador e internet, duas mesas, dois armários de arquivo e mais alguns objetos no canto direito da entrada. Um quadro com painel bem grande de recados e informações sobre a cooperativa foi colocado sobre a única janela desse cômodo, reduzindo significativamente a luz e a ventilação. Havia uma porta que dava acesso a outros compartimentos e a outra saída pelos fundos, onde tinha uma cozinha caipira com fogão de lenha e um lavatório, com uma muretinha em volta. Ali também havia objetos guardados no chão. Em um cômodo, ao lado da sala de entrada, estavam guardados muitos objetos recolhidos e também muitos livros coletados, alguns em uma pequena estante e muitos empilhados pelo chão. Contaram-me que a intenção era formar uma sala de leitura. No lado direito da porta de entrada, na varanda da frente da casa, havia muito material depositado também, pilhas de papelão já amarrados no fardo e outros objetos. Vi que na casa toda há muito material dos resíduos coletados guardado pelos cantos.

Conversando com uma catadora, enquanto ela lavava algumas vasilhas na cozinha, ela me contou que morava ali com a família: o marido e duas crianças que já estavam na escola, mas que era por pouco tempo, eles estavam juntando dinheiro para comprarem uma casa na cidade de origem, no interior da Bahia. Além dessa família havia mais três homens, todos alfabetizandos, que moravam ali. Um deles possuía família, a esposa e os filhos já grandes, que trabalham na cooperativa Acop, onde a família possuía uma casa. O cômodo que ele ocupava era um pequeno "puxado" feito na varanda lateral direita da casa. Ali havia muito material guardado, um amontoado de coisas que reduzia e entulhava o espaço. Vi rato disputando lugar com as coisas e as pessoas. Percebi que ali era um lugar que precisava ser tratado, aquelas pessoas precisavam se perceber dignas de um lugar bom e bonito para trabalharem e estarem. Imaginei um lugar limpo e bem cuidado, uma biblioteca organizada, 
flores caindo de vasos pendurados naquela varanda, uma horta bonita e bem cuidada enriquecendo as refeições ali, um jardim com flores enfeitando a entrada, um canteiro de chás para aliviar as dores.

A segunda visita agendada foi para a coleta de dados e, juntamente com uma bolsista da Incubadora, fomos novamente recebidas pela presidente. Lembrei a ela que estava retornando para fazer o levantamento dos dados escolares para a formação da turma e, em seguida, ela chamou todo o grupo para uma reunião conosco. Interessante como eles se comunicaram rapidamente, semelhante ao que se sucedeu na cooperativa CooperMas. Ela falou com um catador, a notícia foi se espalhando pelo pátio feito brincadeira de correio sem fio e logo foram chegando e se acomodando na parte da frente da varanda e próximo ao canto esquerdo que dobrava para o fundo da casa. Nesse lugar, as pessoas se agruparam da melhor maneira que o espaço permitiu, ficando um círculo um pouco disforme. Demonstraram já estarem habituados com aquela situação. Para esse contato eu levei o questionário. Expliquei a todos do que se tratava, combinamos de uns irem ajudando os outros para que terminássemos mais rápido e que eu e a bolsista também poderíamos escrever para quem precisasse. Distribuí o questionário e canetas para todos. Foram 24 questionários respondidos, indicando 3 não alfabetizados e 2 com o ensino médio completo. Um senhor, alfabetizando, de quem anotei suas respostas ao questionário, falou ao receber o material: "Meu pai dizia que caneta boa era o cabo da enxada".

Figura 19 - Mãe natureza

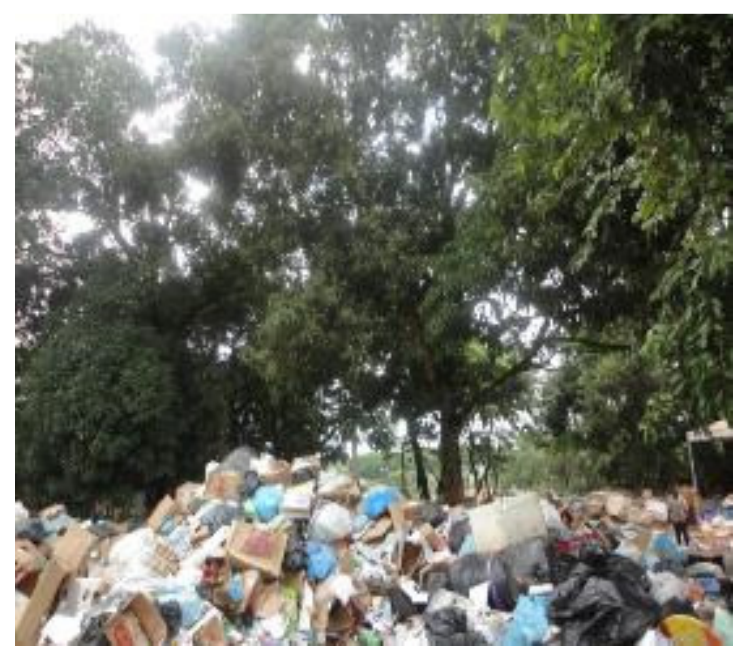

Figura 20 - Invasão de resíduos

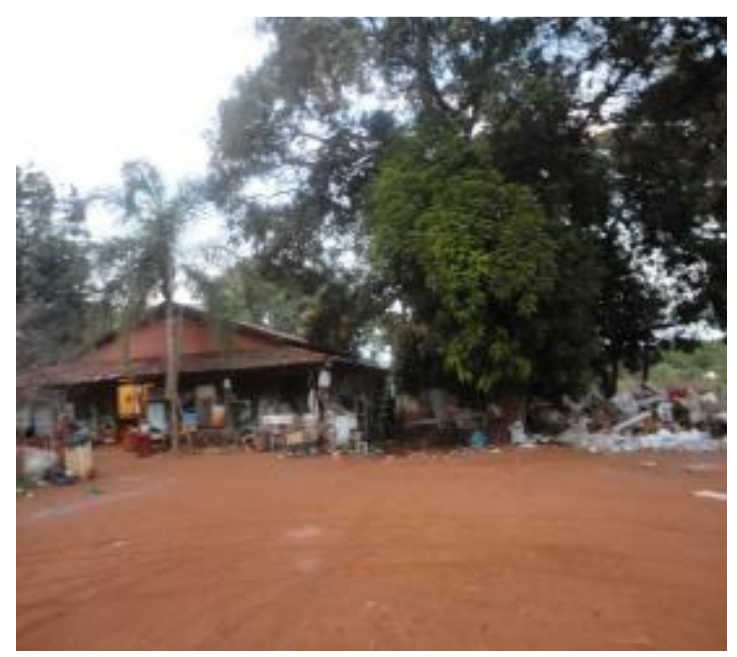

Fonte: Acervo da pesquisa. Ano: 2014.

Guarani: foi a terceira cooperativa visitada e também visitei por duas vezes, sempre acompanhada por bolsistas da Incubadora. A primeira visita foi dia 20/11/2013, fui em meu próprio veículo, seguindo o veículo onde estavam os bolsistas. Nesse dia foi uma equipe 
maior da Incubadora, porque essa era uma cooperativa nova que estava em processo de instalação e a sua gestão e contabilidade estavam sendo cuidados bem de perto pela Incubadora. Reunimo-nos com 12 cooperados. Um bolsista orientou a respeito da forma como devem se organizar para fazerem o pagamento dos cooperados, fez orientações com relação à contabilidade. A conversa depois revelou que, embora a cooperativa sendo nova, havia catadores antigos trabalhando ali. Informaram-nos que no sábado o expediente na cooperativa é somente com o bazar. O bazar é a venda de produtos oriundos da triagem da cooperativa e de produtos artesanais: vasos com garrafas de vidro e árvores de natal feitas com garrafa pet, mas que não é todo sábado. Uma catadora disse, me dando um recado, que está acostumada a receber pesquisador da UFG e que depois eles somem sem dizerem mais nada. Outra catadora, mais jovem, disse que parou de estudar no $1^{\circ}$ ano do ensino médio porque não viu possibilidade de ir para a universidade, disse que é preciso criar uma universidade para os catadores. Expliquei sobre o projeto para formar uma turma de alfabetização de catadores e que voltaria para fazer o levantamento dos interessados em participar.

Essa cooperativa também estava instalada em uma chácara bastante arborizada. Além de mangueiras, havia outras árvores frondosas e bananeiras. Era um espaço bonito e bem amplo. Alguns catadores moravam ali mesmo, em uns quartinhos construídos lado a lado, em um bloco separado que pareciam ruínas, e outros na casa sede. Essa casa era um barraco, bem simples, de chão batido, paredes de tábuas e papelão. Ali havia uma cozinha que nos abrigou em volta de uma mesa. O presidente era um rapaz novo, mas muito empenhado no trabalho de catador. Nessa cooperativa havia um cachorro muito bravo que precisava ser colocado em uma corrente, para que pudéssemos ficar ali. O bolsista que estava ali conosco já havia sido mordido por esse cachorro e tomado várias injeções no tratamento feito. Embora estivesse sob controle, eu fiquei apreensiva com essa situação.

A segunda visita na cooperativa Guarani foi em 10/02/14, por volta das $15 \mathrm{~h}$, para a aplicação do questionário. Nesse dia havia poucos catadores. A greve da coleta seletiva estava afastando os catadores que saíam em busca de outros serviços. Eu fui junto com o bolsista, de carona no transporte da Incubadora. O bolsista tinha um atendimento de orientação sobre as contabilidades para fazer. Assim que finalizou, nos reunimos na casa sede para responder o questionário. Fiz uma explicação mais rápida, pois esse já era o retorno para a coleta de dados, mas nesse dia havia uma educanda que não sabia ainda do projeto. Ela era uma senhora bonita, comunicativa, se expressava com desenvoltura, bem apresentada, estava chegando àquela hora porque estava vindo de uma consulta médica. A julgar pelo que apresentava, ninguém diria que ela não sabia ler e escrever. Aliás, nessas andanças percebi 
que o analfabetismo tem aparência disforme, se instala no interior das pessoas e as obriga a arquitetar maneiras de reinventar a vida na convivência com o mundo letrado.

Distribuí os questionários e também canetas para que respondessem. Foram 7 questionários obtidos e apresentaram uma demanda de 4 alfabetizandos, um catador não quis participar da pesquisa e me informaram que ele não sabia ler e escrever. O bolsista e eu auxiliamos os que não conseguiam responder por não saberem ler e escrever. Outros dois disseram saber ler, mas pediram ajuda mesmo assim pela dificuldade em ler e escrever. Os alfabetizandos, e até outros catadores, manifestaram grande interesse em fazer parte dessa turma e essas manifestações faziam crescer em mim o compromisso em envolver todos os educandos detectados e também me faziam pensar em um tipo de atendimento alternativo que pudesse envolver a todos.

Figura 21 - Resíduos das sombras

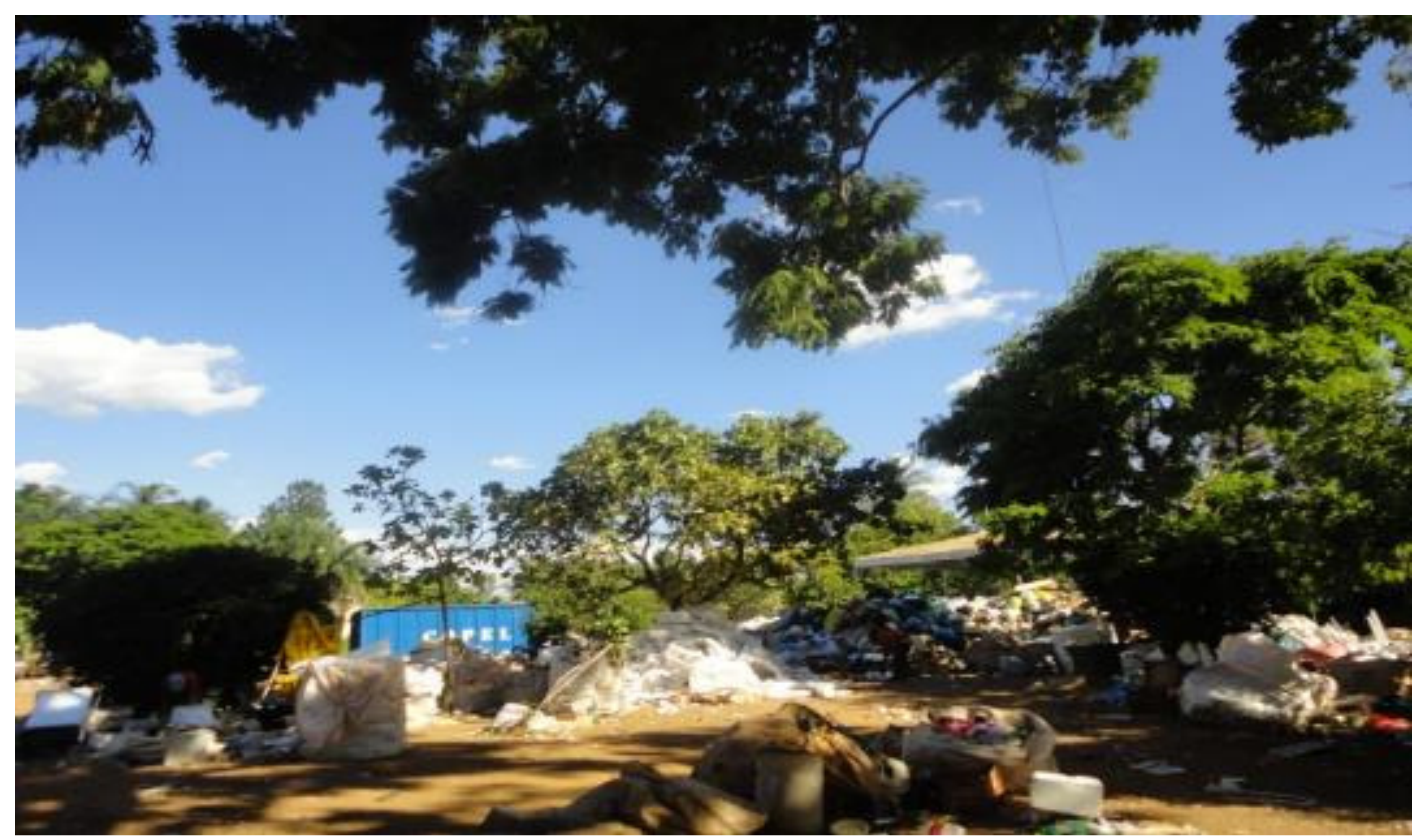

Fonte: Acervo da pesquisa

Cooperfam: Cooperativa de Selecionadores de Materiais Recicláveis Família Feliz foi a quarta cooperativa visitada. A Cooperfam fica localizada no Galpão - Chácara Maringá, n. 92, km 04, Rodovia GO-060, saída para Trindade. Estive nessa cooperativa em uma tarde chuvosa e nublada do dia 18 de dezembro de 2013, por volta das $15 \mathrm{~h}$. Estive junto com a bolsista da Incubadora que acompanha essa cooperativa, ela havia feito o agendamento para essa visita. A chácara onde essa cooperativa está instalada é uma área ampla, estimo que não menos que uns 5 mil metros quadrados. Tem algumas árvores, bem poucas, mas comi goiaba de vez colhida no pé. Em um clima alegre, descontraído, algumas catadoras nos receberam ali, perto da goiabeira, e nos encaminharam para o galpão onde estavam trabalhando os outros 
catadores. O galpão é bem grande e alto, todo fechado com paredes de tijolo e sem janelas. Logo depois de minha chegada, entrou um caminhão da coleta seletiva para descarregar. Observei que o caminhão entrava no galpão e descarregava lá dentro, diretamente no lugar onde faziam a triagem.

Nessa tarde estavam 15 catadores na cooperativa. As catadoras que nos receberam foram avisando, a notícia se espalhou e logo estávamos todos reunidos, sentados sobre caixas, sacos de garrafas pet, latas, papelão. Me chamou a atenção nessa cooperativa a presença das mulheres, eram 12, enquanto havia somente 3 homens e um deles era o presidente. Me apresentei e expliquei da pesquisa que estava fazendo para formar a turma de alfabetizandos. Gostaram da ideia, embora somente dois cooperados fossem alfabetizandos, e alguns disseram que gostariam de frequentar uma escola para os catadores. Distribuí o questionário e canetas e a roda foi se organizando em pequenos grupos, com uns ajudando os outros em clima de descontração. Pelos dados coletados, apenas uma catadora estava estudando, 5 informaram que possuíam o ensino médio completo, 5 tinham o ensino fundamental incompleto, 1 com o fundamental completo, 2 eram apenas alfabetizados e 2 que não sabiam ler e escrever.

Figura 22 - Galpão Maringá

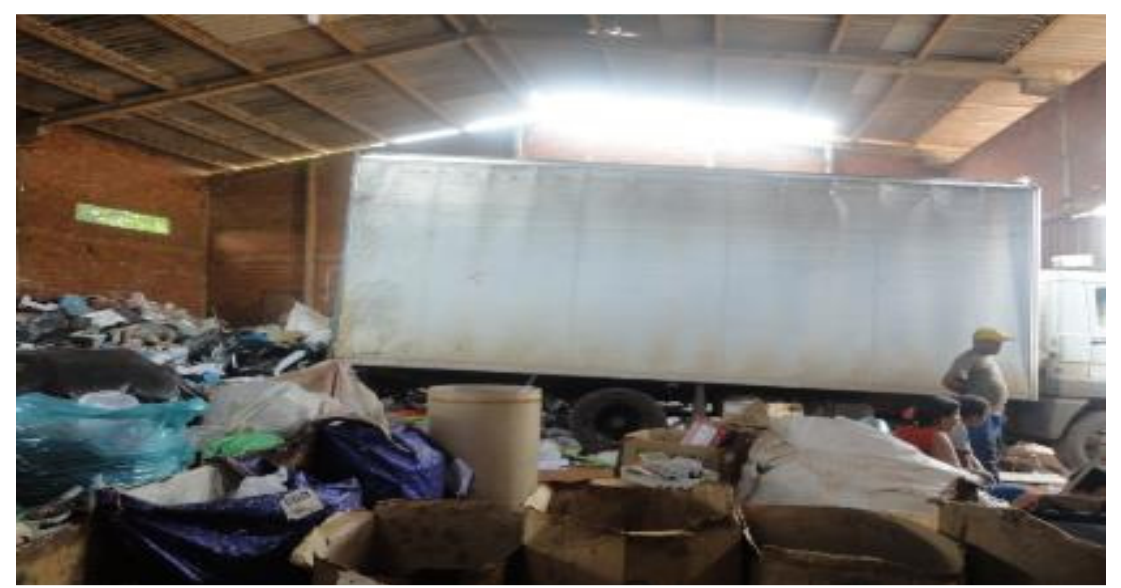

Fonte: Acervo da pesquisa. Ano: 2014.

Acop: Associação de Catadores de Materiais Recicláveis Ordem e Progresso - foi a $5^{\text {a }}$ cooperativa visitada. Ela fica localizada na Área AP3, esquina da rua Sab 3 com Avenida das Américas, no Setor Albino Boaventura, Região Noroeste. Foi nessa comunidade, no entorno dessa cooperativa, onde, após percorrer todas as cooperativas Incubadas, pude instalar a turma de catadores alfabetizandos para a realização desta pesquisa. A minha primeira visita, para apresentação do projeto e levantamento de dados, foi no dia 19/12/13, por volta das $15 \mathrm{~h}$. Havia um agendamento prévio feito pela bolsista que acompanhava essa cooperativa e fomos juntas. Assim que chegamos, todos pararam as atividades e foram se organizando em círculo, 
sentados em lugares improvisados sobre caixas, latas, papelões e bags. Percebi que as pessoas dessas cooperativas incubadas interrompiam o serviço com tranquilidade, sem demonstrar aborrecimento, ou estranhamento, sempre que eram chamadas para uma reunião. Havia um ambiente de descontração, de brincadeiras entre eles e isso me deixou mais à vontade para a conversa com eles.

A reunião foi realizada com 12 cooperados. Havia 8 mulheres e 4 homens. Os dados coletados apontaram uma demanda de 5 catadores que não sabiam ler e escrever, 2 com o ensino fundamental completo, 3 o fundamental incompleto e dois não quiseram informar. Somente 3 estavam estudando, 9 estavam fora da escola. A maioria ia para a cooperativa a pé, somente 1 ia de bicicleta e outra de transporte público, pois moravam na comunidade em torno da cooperativa. A cooperativa estava instalada em uma área própria, escriturada pela prefeitura, para esse fim, não precisavam pagar aluguel. Era um terreno de 3 mil metros quadrados e sem nenhuma árvore. Observei uns vasinhos com flores, feitos de garrafa pet, presos em uma coluna do galpão. Um detalhe que me chamou a atenção pelo contraste entre o peso dos resíduos e a delicadeza daquelas flores. Por mais sutil que fosse, elas transmitiam mensagem para mim, como pesquisadora de EA, mas, especialmente, para aqueles catadores que as cultivavam. Essa cooperativa ficava a uns 50 metros do córrego Caveirinha e a uns 100 metros do encontro desse córrego com o córrego Cascavel. Havia somente um galpão onde tinha a máquina de prensar e uma bancada para a triagem. Nem banheiro havia ali, usavam banheiro em suas próprias residências ou nas mais próximas. O material que chegava era depositado no chão dentro do galpão e em volta, quando ficava muito cheio. A presidente dessa cooperativa, quando fiz essa visita, era a Naná, a mesma catadora que tornou-se educadora popular auxiliar no trabalho com a turma.

A Acop iniciou suas atividades no final da década de 1990. Ela é fruto da luta de um grupo de pessoas que tinha na coleta de resíduos sólidos pelas ruas o seu sustento. Eram famílias inteiras, pais e mães carregando seus filhos pelas ruas, catando os materiais. Dessa maneira, essa cooperativa adquiriu uma longa tradição de catadora, mas iniciou sua mobilização para se organizar como uma associação a partir do ano 2000. O Seu Iramar, que era o presidente em 2014, foi uma liderança desse grupo na frente da mobilização para se organizarem como uma cooperativa. Foi informado da existência de cooperativas em São Paulo e também que existia um movimento nacional dos catadores. A partir daí se orientou, organizou as pessoas da favela e saiu abrindo portas para o registro da cooperativa, porque, naquela época, ninguém falava em programa de coleta seletiva na cidade, segundo ele. 
(9) [...] Com esse instrumento na mão, que era a cooperativa, a gente começou a articular com a Prefeitura, e a Prefeitura não tinha projeto de coleta seletiva. Isso foi no começo de 2000, a gente já começou a se organizar quanto à associação, só que a gente não tinha o conhecimento aonde ia, aí a gente passou a procurar informações, aonde é que registrava, a gente não sabia, porque é a Acop, foi a primeira associação em Goiânia de catadores de material reciclável ${ }^{18}$.

Com a cooperativa registrada em 2005 e com muita luta junto aos políticos e autoridades, a Prefeitura criou um bairro para onde três favelas da cidade foram levadas, o Setor Albino Boaventura, com casas e infraestrutura de água, luz e esgoto, para morar. Esse é o lugar onde hoje está instalada uma comunidade no entorno da cooperativa. Depois de conhecer as 7 cooperativas incubadas e fazer o levantamento dos educandos que não sabem ler e escrever em todas elas, foi nessa comunidade, no entorno da cooperativa Acop, onde consegui organizar um grupo para a realização desta pesquisa. A história de uma vida de muitas dificuldades e superações, vivida por esse grupo, justifica a resistência de alguns educandos em frequentar a turma. Com essa comunidade convivi ao longo de 8 meses, partilhando a vida na troca de emoções e saberes. Posso afirmar que, hoje, estamos modificados.

Figura 23 - Pausa para a Incubadora

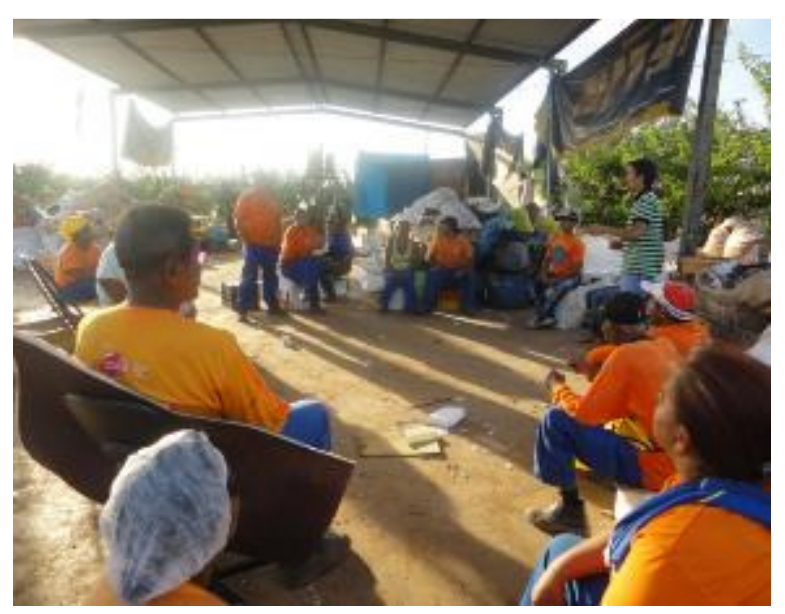

Figura 24 - Pausa para prosa

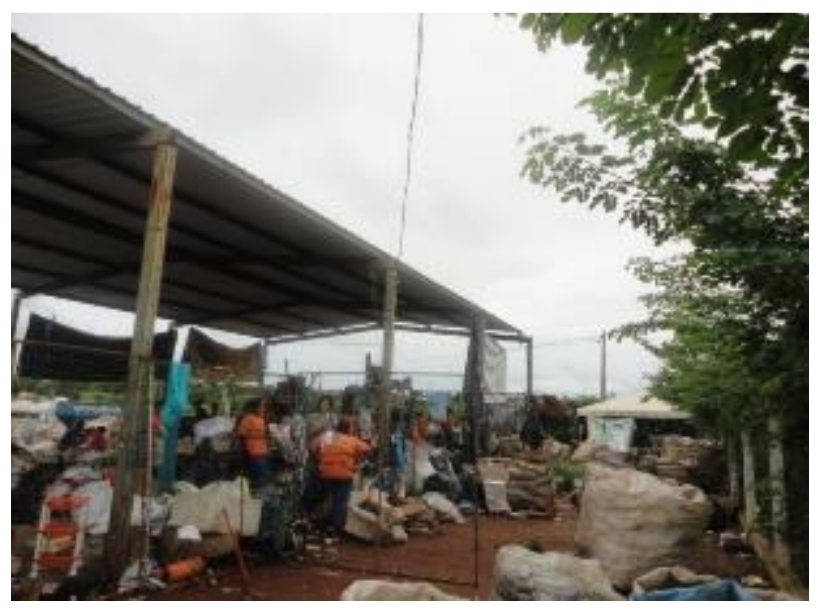

Fonte: Acervo da pesquisa. Ano: 2013.

Cooper Rama: Cooperativa de Material Reciclável "Reciclamos e Amamos o Meio Ambiente" - foi a sexta cooperativa visitada. Ela fica localizada na Rua 55, Quadra 126, Lote 10, no Jardim Curitiba III, Região Noroeste. Ocupa uma área pequena, o galpão ocupa quase toda a área, além dele tem apenas um pequeno quintal. Fica no meio de um bairro bem

\footnotetext{
${ }^{18}$ Entrevista $^{\mathrm{o}} 3$, de $16 / 04 / 2015$
} 
povoado. O seu prédio tem dois pavimentos: no térreo fica o galpão que recebe os resíduos, um lugar fechado, com pouca iluminação natural e ventilação, e no $2^{\circ}$ piso tem o escritório e um espaço grande para reuniões ou outras atividades, pensei na sala de aula. Estive nessa cooperativa no dia 28 de janeiro de 2014, chegando por volta das $15 \mathrm{~h} 30 \mathrm{~min}$. Uma bolsista havia feito o agendamento e fomos juntas. Fiz apenas uma visita a essa cooperativa, nessa visita me apresentei, falei da formação da turma e apliquei o questionário.

Fomos recebidas com o mesmo acolhimento e simpatia que as outras cooperativas. Após a minha fala, algumas catadoras se sentiram estimuladas a falar também e disseram que elas precisam ter a oportunidade para dizer do quanto a sociedade precisa ser preparada, educada, para aprender a lidar com os resíduos sólidos. Manifestaram o desejo de estudar, até disseram que gostariam de frequentar essa sala de aula, mesmo já sabendo ler e escrever. Foram 11 questionários respondidos. Se organizaram em pequenos grupos e foram respondendo juntos, uns ajudando aos outros. Me disseram que naquela tarde haviam faltado dois catadores. Um que estavam lá não quis responder. Sobre a escolarização, os dados informaram que 2 não sabiam ler e escrever, 1 era apenas alfabetizado, 2 tinham o ensino fundamental completo e 3 incompleto, 1 com ensino médio completo e 1 com o superior completo, a única catadora que tinha o curso superior dentre as cooperativas visitadas. Conversei com ela, era uma moça formada em administração de empresa e que trabalhava na parte administrativa da cooperativa, cuidando de toda a contabilidade. Era uma pessoa bem integrada ao trabalho de catador. Dentre os que responderam, somente 2 estão estudando. As manifestações dos catadores dessa cooperativa foram se somando às outras das outras cooperativas, reafirmando o desejo de estudar, mas o desejo de que haja uma escola para os catadores.

Figura 25 - Mulheres no comando I

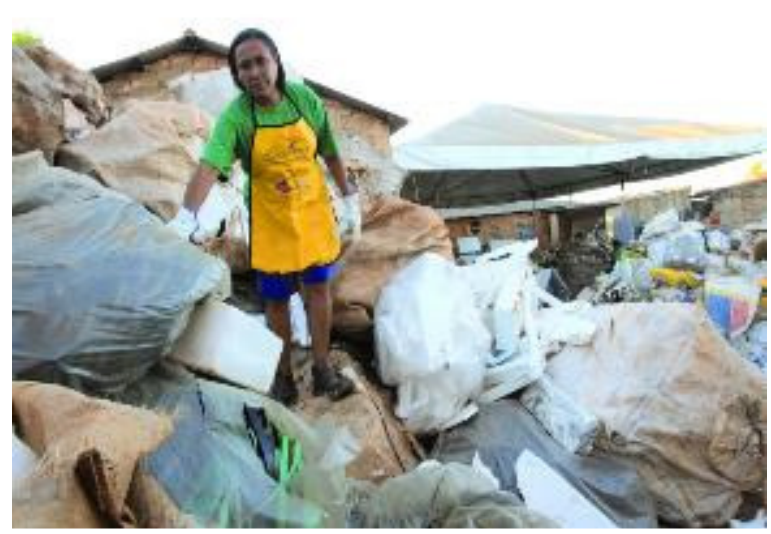

Fonte: O Popular de 08/07/2012
Figura 26 - Mulheres no comando II

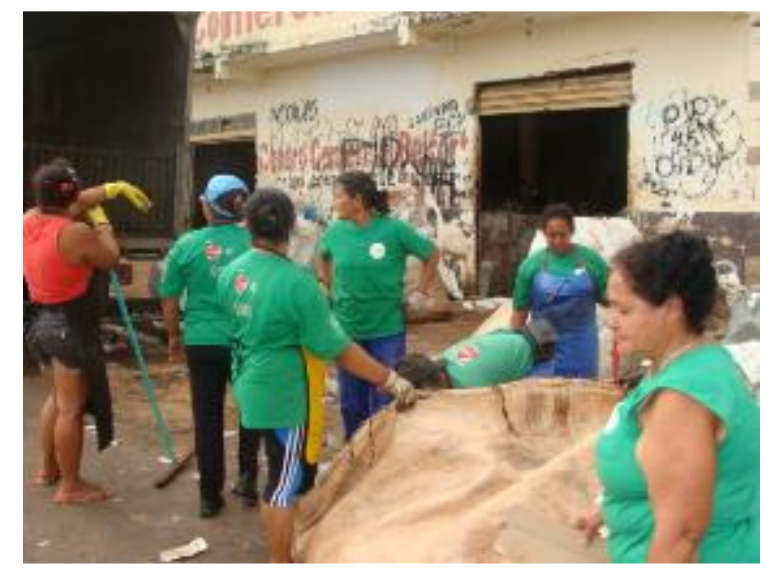

Fonte: Internet - empreendação.com.br. Abril de 2016 
Cooprec: Cooperativa de Reciclagem de Lixo - foi a última a ser visitada. Fiz uma única visita, no dia 21 de fevereiro de 2014, por volta das $15 \mathrm{~h}$. Essa cooperativa confirmou o seu vínculo com a incubadora no início do ano de 2014. Juntamente com a Acop, são as primeiras cooperativas da cidade, e, com histórias bem distintas, ambas são hoje uma referência na história das cooperativas de catadores de Goiânia. Localizada na Travessa Xingu, no Setor Jardim Conquista, na Região Leste de Goiânia, foi criada em 1998, por iniciativa do jornalista Washington Novaes, que atuava na Pontifícia Universidade Católica de Goiás (PUC-GO). O projeto era promover a educação ambiental, reciclagem de lixo, inclusão social e geração de renda para os cooperados. A construção da estrutura da cooperativa foi feita com verbas do governo federal, para aquisição de máquinas, balança de pesagem de caminhão e trator. O Sebrae em Goiás foi um órgão parceiro, realizando cursos de cooperativismo e consultorias.

Ao visitar esta cooperativa, desde a entrada percebi a grande diferença entre a sua estrutura de funcionamento e a das outras cooperativas visitadas: em sua entrada havia um canteiro de jardim com flores, por onde entram também os caminhões. Não se vê o material da coleta seletiva ao entrarmos ali. É uma estrutura projetada para esse fim, portanto, com planejamento para o recebimento do material em uma rampa para os caminhões descarregarem, com locais apropriados para a triagem e o funcionamento de diferentes atividades em um enorme galpão. Além desse, há outro prédio com cozinha e refeitório, que é espaço também para reuniões do grupo, uma sala para administração e uma sala de outros acervos da cooperativa. Tudo num ambiente limpo, cuidado, humanizado. Essa estrutura faz dessa cooperativa um ambiente acolhedor, onde as pessoas são tratadas com dignidade em seu trabalho, valorizando o catador.

No dia da minha ida a essa cooperativa havia 15 cooperados trabalhando. Após conhecer os diferentes espaços e acompanhar um pouco as atividades de triagem, fomos para a sala de refeitório e reunião. Esse foi um dia histórico para essa cooperativa, a reunião marcada era para documentar a adesão dela à Incubadora e, além disso, tinha como ponto central de pauta tratar da criação da Rede Uniforte. Além da Rede Uniforte há também a Cataforte e o Programa CataSol, com especificidades, mas todos voltados para a união e fortalecimento das cooperativas. Após a reunião, fiz a coleta de dados para a minha pesquisa, com o instrumento que elaborei para esse fim. Ali havia somente um catador sem o domínio de leitura e escrita, ficou entusiasmado com a ideia de aprender a ler e escrever, disse que esse sempre foi um sonho. Fui recebida com alegria e entusiasmo pelas catadoras que gostaram do meu projeto de pesquisa e me levaram para uma sala onde guardavam um rico acervo da 
história vivida por essa cooperativa. Apresentaram-me álbuns com fotografias, roupas de teatro, documentos, peças de artesanato, tapetes produzidos com material da coleta.

Essas mulheres me explicaram que elas faziam, pessoalmente, de porta em porta, nos bairros mais próximos da cooperativa, a orientação para as pessoas separarem o lixo em suas casas. Levavam um folder explicativo, que era elaborado por elas em parceria com a Pontifícia Universidade Católica de Goiás - PUC Goiás. Depois passavam recolhendo o material em carroças ou empurrando carrinhos. Fizeram também parcerias com condomínios luxuosos que entregavam o material coletado na cooperativa. Faziam apresentações teatrais nas feiras do bairro, nas ruas, nos locais de movimentação, conversando e entregando o folder. Em 2008, quando tem início em Goiânia o PGCS, os catadores dessa cooperativa já acumulavam uma rica história de EA vivida por eles. Até o dia de minha visita, havia ainda muitas pessoas desse primeiro grupo de catadoras e catadores que continuavam trabalhando nessa cooperativa, com vínculos se fortalecendo a cada ano. Atualmente, a Cooprec caminha sobre suas próprias pernas e compartilha muitas das mesmas dificuldades vividas pelas outras cooperativas: pouco material, rotatividade de catadores, baixa renda, dentre outras.

Figura 27 - Passarela dos resíduos

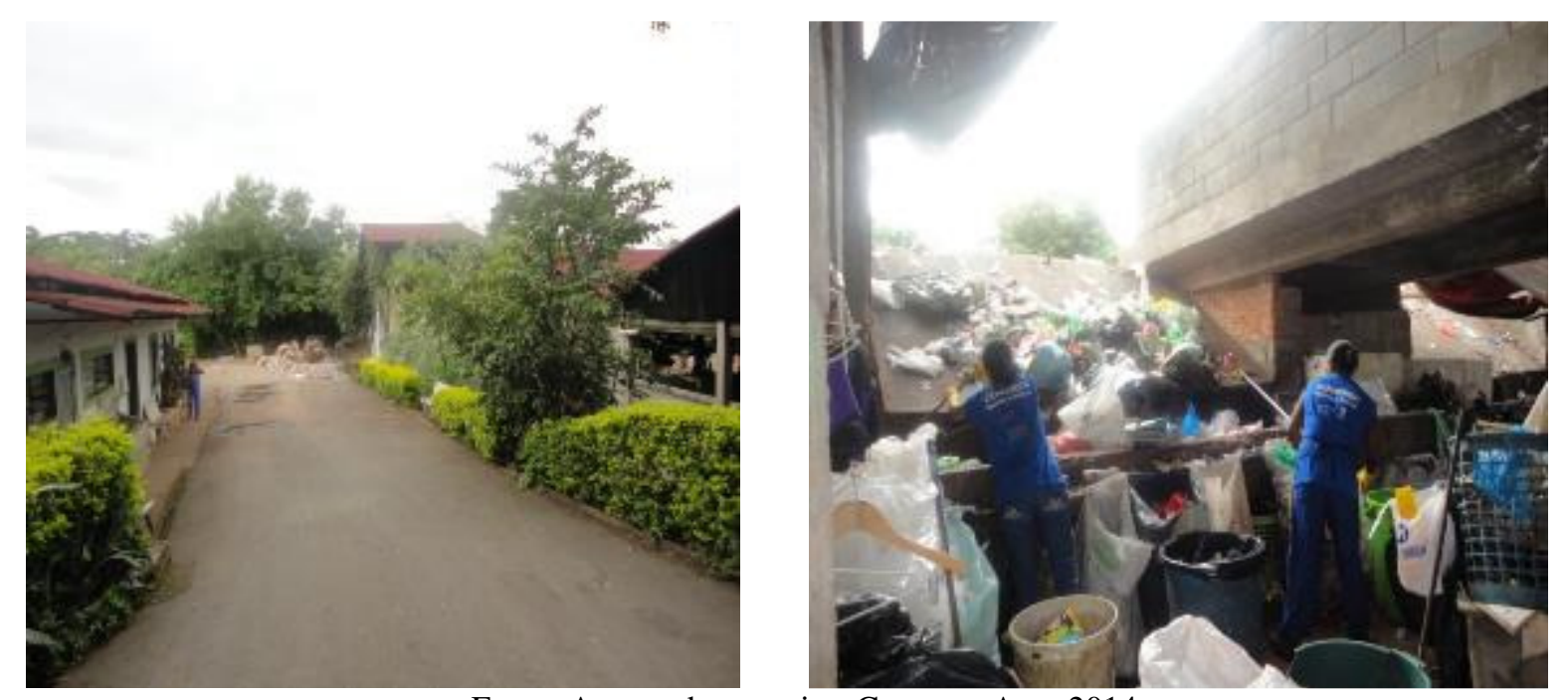

Fonte: Acervo da pesquisa. Cooprec. Ano: 2014
Figura 28 - Rampa de resíduos

O maior interesse dessa cooperativa em se vincular à Incubadora é para o fortalecimento da Rede Uniforte. Segundo boletim da Incubadora divulgado em página do site da $\mathrm{UFG}^{19}$, essa Rede é uma organização das cooperativas na tentativa de se fortalecerem

\footnotetext{
19 Disponível em: <https://www.ufg.br/n/65098-incubadora-social-apoia-encontro-de-mulheres-catadoras >. Acesso em: 04 mar. 2016.
} 
enquanto empreendimentos de economia solidária de geração de emprego e renda. Organizadas em Rede as cooperativas objetivam aumentar a produção, eliminar atravessadores e melhorar a qualidade de vida dos participantes. A cooperativa Cooprec é a proponente dessa Rede e a Incubadora Social da UFG é a executora do projeto. Criada no final do ano de 2013, além da Cooprec, mais 4 cooperativas compunham essa Rede: a Coocamare, a Coooperama, a CooperMas e a Acop. Por meio dessa Rede poderão fazer a venda coletiva do material reciclável, produção de telhas de papelão e a transformação de plásticos em grânulos para a fabricação de mangueiras. Mas, para a efetivação desses objetivos, precisarão de equipamentos, máquinas e veículos, além da adesão de um maior número de cooperativas e até de catadores que ainda estão pelas ruas. Uma ideia muito interessante e totalmente cooperativa, pois a sua força está justamente na adesão do maior número de cooperativas e catadores. Quanto maior a adesão, maior o volume de material reciclável. Com isso, poderão eliminar a figura dos atravessadores e negociar diretamente com as indústrias, uma tentativa de poderem, juntas, ter maior poder de negociação do material reciclável, melhorando, consequentemente, a qualidade de vida dos catadores. Essa Rede é um projeto ambicioso, do tamanho dos sonhos dos catadores. Em entrevista para esta pesquisa Naná ${ }^{20}$ fala sobre as lutas com propriedade:

(10) Olha, acho que toda cooperativa, desde o começo, tem uma luta, uma caminhada. Então se ela não lutar, se ela não caminhar, nada vai pra frente. Se ela não correr atrás, não vem, as coisas não caem do céu. Primeiro, através da luta ela tem um sonho, que é o sonho de ser estruturada, de ser bem sucedida, com galpões, eles fica sonhando. Cooperado que é cooperado sonha. "Vamo ter uma prensa, vamo fechar isso aqui, vamo ter isso, vamo ter uma sala de jogos, um refeitório", eles fica sonhando. Eu falo por mim-que eu sonhava mais a Maria $W$ - que a gente via essas empresa grande, eu falava: "já imaginou?". A gente fica com aquele sonho. E através dos sonhos a gente gera as movimentações, as lutas, as conquistas, as reuniões... As vezes a gente faz manifestações também, através de tudo um vai puxando o outro.

Naná é uma catadora filha de catadores, ela e os irmãos cresceram ajudando seus pais na coleta, por isso, conhece profundamente a vida de catador e fala com autoridade sobre as lutas e os sonhos do catador, ao mesmo tempo em que demonstra já ter se dado conta de como tudo está conectado: a cooperativa, o cooperado, os sonhos, as movimentações, as caminhadas, as reuniões, as lutas, as conquistas, as manifestações, "um vai puxando o outro".

\footnotetext{
${ }^{20}$ Entrevista n ${ }^{\circ}$ 02, de 09/03/2015.
} 
A cidade de Goiânia hoje é rodeada por 15 cooperativas de resíduos sólidos e essas cooperativas são um símbolo do avanço dessa cidade em direção à sustentabilidade. Embora funcionando em condições precárias, não podemos deixar de reconhecer o valor dessas cooperativas e da coleta seletiva para a sustentabilidade dessa cidade, pois a ausência delas significaria o agravamento de um colapso na capacidade de armazenamento do lixo no aterro sanitário de Goiânia. No entanto, não podemos também deixar de perceber, que a maneira como a coleta seletiva vem acontecendo nessa cidade se assemelha bem mais a um atendimento visando projeções políticas, que uma verdadeira consciência de sustentabilidade ambiental, alicerçada na ética, na solidariedade, na relação humana verdadeiramente. Isso se confirma pela realidade que estamos vivenciando, onde o que se presencia é um atendimento extremamente precário que se manifesta pelas condições desumanas das cooperativas sem estrutura adequada para o depósito e manejo do material; pela falta de estrutura de transportes e funcionários suficientes para uma coleta expressiva em toda a cidade; pela falta de participação da população na coleta seletiva; pela falta de condições de uma vida mais digna e mais humana para os catadores.

A fragilidade do trabalho do catador é significativa e de fácil compreensão, pois se não há uma verdadeira consciência ambiental por parte dos gestores públicos, então a coleta seletiva vive sob permanente ameaça e, em seu desdobramento, a vida de centenas de famílias que tiram daí o seu sustento. Isto foi o que ocorreu com a greve da coleta seletiva no início do ano de 2014, pois a prefeitura havia deixado de pagar a empresa contratada para fazer a coleta de porta em porta. Com isso, a vida dos catadores foi profundamente afetada, tiveram que procurar outros serviços, no submundo dos excluídos, pois são pais e mães que precisam sustentar suas famílias. Ao mesmo tempo, as autoridades e toda a população, se comportaram como se nada soubessem sobre o que estava se passando com essas famílias, como se fosse uma realidade distante e apartada do mundo, eximindo-se de qualquer relação ou responsabilidade com essa realidade. O Sr. Fernando, coordenador da Incubadora Social da UFG, em entrevista para esta pesquisa, expressa a sua opinião sobre o papel do poder público, e o de todos nós, para a melhoria da realidade das cooperativas:

(11) (...) o que eu vejo numa opinião particular minha é que os governantes precisariam olhar isso com mais cuidado, ter aí uma possibilidade de maiores investimentos nessa questão da estruturação das cooperativas porque a gente percebe também que de certa forma a coleta seletiva ainda é relegada a um segundo plano. A gente tem observado que nas cooperativas tá chegando muitos materiais que não são recicláveis, que não são comercializáveis e isso vai entulhando a cooperativa e transformando aquele ambiente praticamente num outro lixão e a gente tem pedido um 
esforço maior na questão da Educação Ambiental e esse é o ponto de partida para que as pessoas possam saber que o material reciclável não é lixo, o material reciclável é um produto que vai gerar trabalho e renda para aquelas pessoas. Antes de saber o que que vai ser separado precisaria ter essa compreensão.

A falta de orientação e estímulo à população para que participe da coleta seletiva é uma grande barreira que ainda precisa ser transposta. A coleta seletiva é um fio condutor que nos entrelaça, que nos conecta com a construção de uma cidade sustentável, um tipo de cidade que somente pode ser construída com a participação de todos. Amplas campanhas publicitárias na televisão, nos jornais, nas escolas e universidades, em praças e painéis precisam ser feitas orientando e estimulando a coleta, assim como apresentando e valorizando o catador, envolvendo toda a população na importância da colaboração de todos num grande movimento solidário em defesa da vida, onde todos se beneficiam ao participar desse grande ciclo solidário. Ações que nos parecem simples, mas capazes de causar uma grande movimentação em toda a cidade, envolvendo-a em um ambiente de profunda e imensurável transformação. Esse deve ser o desafio posto àqueles que se comprometem com essa realidade na construção de um mundo melhor, mais justo e mais humano. Sobre essa confluência ambiental e social o Sr. Fernando comenta também, a partir do contexto dessas cooperativas:

(12) [...] eu considero que nessa questão da coleta seletiva envolvendo as pessoas, os catadores de material reciclável, ela não é apenas uma questão [apenas] ambiental ela é também uma questão social, porque o que a gente conhece e sabe é que essa atividade já há algum tempo, da catação de material reciclável, da recuperação desses materiais nos lixões, nas ruas [...], é feita por essas pessoas. E aí essas pessoas trabalharam durante muitos anos de forma desarticulada e desorganizada e abandonadas, sem acesso à saúde, sem acesso à educação e sem acesso a..., enfim, totalmente excluídos. Então eu vejo assim [...], que é uma questão social e ambiental, as duas andam muito juntas. Social por conta disto que eu estou dizendo, de ajudar a organizar as pessoas em cooperativas pra terem um trabalho digno, que saiam deste ambiente que são os lixões, deste esforço sub-humano que é puxar os carrinhos na rua e essas coisas todas não é? E na questão ambiental, que eu percebo, é que há uma enorme contribuição na preservação e na possibilidade de aumentar a vida útil, principalmente dos aterros, de forma que isso traz os seus benefícios pra sociedade de uma maneira geral e é uma contribuição importante para toda essa questão das discussões ambientais.

A precariedade da vida dos catadores submersos no submundo da exclusão, associada à falta de escolarização, submete esses catadores à sujeição de uma condição social que lhes rouba também a competência de se perceberem como sujeitos capazes de transformar essa condição. Dessa maneira, entendo que é necessário dar as mãos e estimular a organização do 
movimento dos catadores, ampliando ações em defesa desses sujeitos e das cooperativas a partir da diversidade de possibilidades apontadas pelo contexto da realidade de cada uma delas. Nesse sentido, considero que a Incubadora Social, como órgão de extensão de uma Universidade Federal, a UFG, aberta à multirreferencialidade do conhecimento, pode ter um papel relevante à frente da diversidade de ações que podem ser implementadas em um movimento intensificado e contínuo de fortalecimento das cooperativas. Um movimento que não se efetiva apenas no suporte logístico, mas em uma formação que lhes amplie a visão das possibilidades de transformação, que lhes faça perceberem a força de mudança que eles conduzem, um movimento de superação da naturalização da submissão. O Sr. Fernando nos conta como a Incubadora tem colaborado:

(13) A Incubadora é uma apoiadora, ela não interfere no movimento. $O$ movimento, inclusive, pra ser legítimo ele tem que ser somente dos catadores, então como apoiadores o que que nós fazemos? Nós damos a estrutura, por exemplo, nós sedemos espaço pras reuniões, eles fazem reuniões aqui e muitas vezes nós nem participamos da reunião porque eles é que precisam exercitar isso. Às vezes, conforme a necessidade é preciso de um veículo pra fazer alguma reunião na cooperativa a gente fornece, alguma assessoria na elaboração de algum documento, tomam a decisão lá e precisa escrever um documento, só alguma coisa assim nesse sentido, mas nós não participamos, não discutimos com eles lá, o que que é o nosso entendimento? Eles precisam exercitar essa prática de discutir os seus próprios problemas, de buscar solução pros seus próprios problemas. Quando surge alguma dúvida aí sim a gente, por exemplo, quando solicitam algum esclarecimento, alguma informação nós ajudamos e nós apoiamos nesse sentido.

(14) $O$ que nós queremos como Incubadora, a Incubadora não quer amarrar nenhum segmento, nenhuma cooperativa de forma definitiva que não vão sobreviver sem ela, muito pelo contrário. A incubadora, por isso se chama Incubadora, espera-se que depois de um determinado tempo haja essa formação que seja o que lhes dê capacidade de andar com suas próprias pernas, tomar suas próprias decisões, ter lá a sua organização e autonomia independente da Incubadora. A Incubadora vai pra outros projetos não só de cooperativas de catadores, por exemplo, nós estamos começando a discutir agricultura familiar, então a ideia é de que esse movimento se torne independente mesmo e caminhe com suas pernas, mas de uma forma consciente, de uma forma que saiba o que tá fazendo.

A maneira como a Incubadora está colaborando, conforme o que nos foi revelado, aponta, por um lado, o cuidado da Incubadora em respeitar o tempo e a territorialidade dos catadores, por outro lado, aponta a falta de uma formação a esses catadores que lhes amplie a capacidade de percepção do seu lugar e do mundo que os envolve. Nesse sentido, as questões que emergem são para saber: deve ser somente esse, de fato, o papel dessa Incubadora? Deve 
essa Incubadora, por meio da UFG, proporcionar formações a esses catadores? Se isto for considerado, que tipo de formação? Entendo que devem os catadores opinar, participar e decidir sobre isso, mas a realidade nos indica que essa é uma questão urgente, não é mais possível continuarmos convivendo com essa situação e deixando que ela se resolva por si própria. As forças sociais repressoras do movimento emancipatório estão presentes, atuantes e fortes na contramão do movimento de um grupo social, fragilizado, desarticulado e submisso às precárias condições de sobrevivência, forças que andam na contramão também do próprio movimento da EA e da EP.

A participação de todos, portanto, é condição para a melhoria da qualidade de trabalho dessas cooperativas, o poder público dificilmente se envolverá em um movimento de valorização e reconhecimento do catador como uma categoria profissional. Esse é, de fato, um movimento que se inicia pelas bases, mas é um movimento que precisa ser feito e a EA tem aí um papel relevante de compromisso social e de formação do ser, para que se perceba como cidadão, como alguém que pertence a esse mundo, com sua história e com sua contribuição para a construção de um mundo melhor. O pertencimento, portanto, é um sentimento imprescindível para a participação coletiva, pois ele é o ponto de partida para o compromisso com a vida.

Desde que nascemos, pertencemos a algum lugar, um lugar situado no Planeta Terra e o compromisso amoroso no cuidado de todos pela manutenção da vida se efetiva na medida em que cada um se percebe pertencente ao planeta, pertencente ao cosmos. Com a profundidade e a poesia das coisas simples, Brandão (2005. p.12) nos diz que:

\footnotetext{
Houve um momento em que eu nasci. Houve momentos em que você, eu e todos nós nascemos e começamos a viver a aventura da vida em algum lugar do Planeta Terra. E a Terra é a casa de todas e de todos nós. Ela é o nosso lar.

Nascemos em um dia em um lugar.

E a partir de então nós existimos. Somos alguém.

Somos uma pessoa no mundo em que nascemos e onde vivemos.

Parece tão natural e parece tão estranho ao mesmo tempo. E é isso mesmo: existimos. Estamos - você, eu e nós - situados dentro de um tempo e de um lugar. (Grifos do autor)
}

O espaço do lugar onde nascemos ou vivemos se encontra com o espaço do tempo de nossa existência aqui. E o encontro desses espaços de tempo e lugar em nossa subjetividade é o ponto onde nos localizamos e de onde interagimos com o mundo. Um mundo habitado por muitas vidas e em permanente transformação. Transformação porque todas as vidas vivem um 
ciclo de constante mudança e renovação em seus espaços de tempo e lugar inseridos nos ciclos da natureza. Dessa maneira, a natureza é "um espaço em movimento dinâmico, cíclico, em que a inter-relação e a interdependência garantem sua reprodução e manutenção." (ZANETI, 2006, p. 47). Mas a humanidade fez a opção por um modelo de relação predatória com a natureza, desrespeitando seus ciclos, e a sustentação dessa escolha sacrifica o pertencimento, que, ofuscado, cede lugar à perda de sentido, à falta de consciência e à ausência de criticidade. $\mathrm{O}$ caminho escolhido tornou a humanidade refém de um mundo direcionado essencialmente para a manutenção do lucro, da ganância, da exploração desmedida de tudo e de todos, para a apropriação indevida do Sol, da Terra, da água e do ar.

Os conflitos, as tensões, a fome, o aquecimento global, as doenças, o descontrole da vida, está levando a humanidade a se dar conta cada dia mais de que há algo de errado com a escolha de desenvolvimento que tomou. Ela já percebeu que não pode haver desenvolvimento em desarmonia com a natureza e que esta está chegando ao seu limite de sustentação da vida, em decorrência da exploração desenfreada e desrespeitosa de seus ciclos. Agora, o dilema é um só: ou a humanidade abre mão do seu modelo de desenvolvimento econômico sustentado na destruição da natureza, ou abre mão da vida no Planeta Terra, dentre essas, a própria vida humana. Embora esteja consciente desse dilema, a humanidade ainda não conseguiu fazer outras escolhas e mudar o rumo de sua trajetória no Planeta.

É esse o contexto onde se localizam as cooperativas de catadores de Goiânia, elas fazem parte desse ciclo de manutenção da vida que envolve toda a sociedade. O modelo autogestionário é mais um ponto de coerência entre o funcionamento dessas cooperativas e o princípio de solidariedade e respeito à vida capazes de mudar essa trajetória do Planeta. A manutenção, portanto, de condições adequadas de funcionamento dessas cooperativas está vinculada à própria tomada de decisão da humanidade quanto ao seu modelo de desenvolvimento. A coleta seletiva e as cooperativas podem, portanto, se fortalecer e originar um movimento capaz de impelir a humanidade a fazer a opção pela vida. 


\section{CAPÍtUlO 5}

Apresentação dos resultados e análise interpretativa dos dados: correnteza das águas

Figura 29 - Correnteza do Rio do Meio

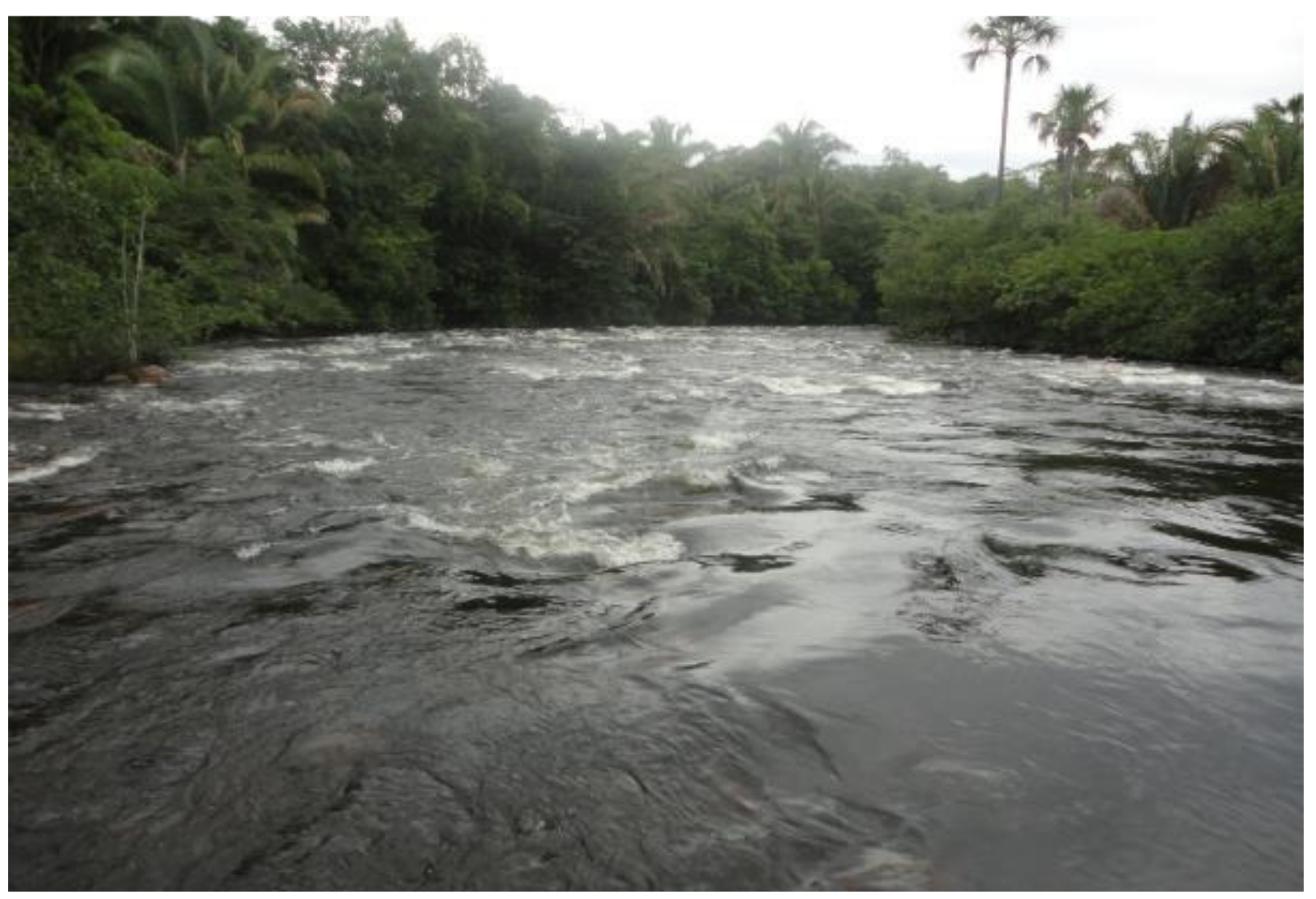

Fonte: Acervo de Dinorá de Castro Gomes. Janeiro de 2008. 


\section{CAPÍTULO 5 - APRESENTAÇÃO DOS RESULTADOS E ANÁLISE INTERPRETATIVA DOS DADOS: CORRENTEZA DAS ÁGUAS}

Aprendi a poupar a minha água em casa.

Vixe Maria, eu abria a torneira chega esquecia. Agora não.

Maria M

\subsection{Introdução: a terceira margem do rio}

A inclusão da Educação Ambiental no trabalho com a alfabetização de adultos catadores direciona o olhar para a imersão em um espaço humano multidimensional e multirreferencial. Um lugar onde "o ser humano é ao mesmo tempo: biológico, psíquico, social, afetivo e racional." (MORIN, 2003, p. 38) e o conhecimento envolvendo as mais diversas áreas, sob a perspectiva da totalidade complexa. A abrangência da experiência realizada adentra situações localizadas no tempo e no espaço que acompanham a realidade dos catadores colaboradores desta pesquisa, e interagir com essa realidade foi o grande desafio deste estudo. Para enfrentar os desafios, me debrucei em apreender a ordem que regia as relações da teia de sustentação da vida na comunidade onde a experiência se efetivou, buscando a maior aproximação possível entre essa realidade e a experiência de alfabetização que se pretendia realizar.

O empenho neste momento é fazer a exposição da experiência realizada. Com essa intenção, explicito às vezes conceitos e às vezes concepções, em busca de acompanhar os meus passos e trazer a compreensão de um estudo que procura contribuir no campo da EA, demonstrando a capacidade transformadora de suas estratégias, aliadas à força dos princípios da EP, que direcionam para a visão crítica da sociedade. Contudo, considero Morin (2008, p. 21-22) quando diz que "Eu estou cada vez mais convencido de que os conceitos dos quais nós nos servimos para conceber a nossa sociedade - toda sociedade - são mutilados e resultam em ações inevitavelmente mutilantes."

A sistematização a que me lanço neste momento, portanto, tenta romper em busca de um olhar integrador que supere as mutilações, mas vou me dando conta de que a totalidade da existência habita uma zona de não resistência localizada em dimensões fora da percepção de nossa capacidade humana racional, que me lançam na terceira margem do rio. Se a busca que estamos empreendendo atualmente no universo da EA é pela construção de uma outra lógica 
de compreensão e, especialmente, de interação com o mundo, então, os mesmos pares binários fragmentados pela lógica cartesiana: parte-todo, simples-complexo, local-global, unidade-diversidade, particular-universal, são retomados a partir do princípio hologramático proposto por Morin (2015) que afirma que a parte não somente está dentro do todo, como o próprio todo também está dentro das partes, ressurgindo como capazes de nos conduzir a uma nova escuta, uma escuta agregadora feita com o coração.

Após essas considerações, esclareço que neste capítulo me dedico a fazer os acoplamentos, trazer à superfície da película que nos envolve a todos a face oculta das relações que permeiam os sujeitos desta pesquisa. Fazer conexões, almejando, por meio da experiência realizada, ligar as dimensões tangenciadas pela junção da Educação Ambiental à Educação Popular, apontadas ao longo do estudo. Assim, vou me lançando, retomando algumas explicitações e definições metodológicas que me acompanham neste percurso. Em seguida, apresento o percurso, a trajetória turbulenta, carregada de sentidos, que foi percorrida, a partir das primeiras pedras contornadas, até chegar à turma constituída. A partir daí, procuro focar na experiência com a turma, na comunidade onde se deu o processo de alfabetização, ponto de onde passaram a emanar outras demandas.

No percurso, vou desdobrando o capítulo pela narrativa da experiência realizada, onde os elementos envolvidos vão emergindo, se transformando em dados e, a partir deles, as informações vão se cruzando, fazendo ligações, se agrupando em temas que articulam as análises. Ao falar sobre método, Morin (2008, p. 29) explica sobre que tipo de método necessitamos dizendo que "Hoje, a nossa necessidade histórica é de encontrar um método que detecte e não que oculte as ligações, as articulações, as solidariedades, as implicações, as imbricações, as interdependências, as complexidades". Nesse sentido, os passos apresentados são opções de exposição da pesquisa, que estão interconectados, em interação contínua e em intrínseca movimentação, constituindo o todo em ininterrupto movimento sistêmico e dialético. Todas essas ações têm como foco responder as questões norteadoras da pesquisa, que buscam saber qual a contribuição da EA para uma aprendizagem significativa na alfabetização de adultos trabalhadores de cooperativa de resíduos sólidos e de que forma as estratégias ecopedagógicas podem contribuir para a formação humana emancipatória de alfabetizandos trabalhadores de cooperativas de resíduos sólidos. Questões provenientes do objetivo orientador deste estudo, que intenciona "Analisar a contribuição da Educação Ambiental para alfabetização e formação humana junto a uma turma de trabalhadores em cooperativa de catadores de resíduos sólidos na cidade de Goiânia”. 
A experiência de alfabetização dos adultos trabalhadores nas cooperativas de resíduos sólidos, com estratégias de EA, na forma como foi proposta, em uma turma formada somente por trabalhadores de cooperativas de resíduos sólidos, despontou-se como algo inédito na cidade de Goiânia. A minha ideia inicial era instalar essa turma no Campus II da Universidade Federal de Goiás, pensando facilitar o acesso de todos os cooperados alfabetizandos das cooperativas incubadas a uma sala de aula, por meio da parceria com a Incubadora Social da UFG. Estava entendendo que seria uma localização estratégica em relação às cooperativas e com um espaço físico adequado cedido para a instalação da turma, numa sala na própria Incubadora, reservada somente para esse fim, mas isso envolveu outras questões que inviabilizaram essa possibilidade: a necessidade de veículos para o transporte e, mesmo assim, permanecia a dificuldade para o deslocamento devido à distância das rotas, longo tempo de percurso devido ao trânsito e ao cansaço do fim de um dia de exaustivo trabalho nas cooperativas.

O percurso que trilho de agora em diante segue sustentado por essas águas que me localizam na "Terceira margem do rio" ${ }^{21}$ ", pois na medida em que identifico o meu objeto de pesquisa e tento responder às questões que me conduzem vou encontrando lugar para os questionamentos existenciais. Afinal, como saber qual a contribuição da EA para uma aprendizagem significativa, sem vivenciar essa experiência em meus próprios caminhos internos? Como propor uma educação transformadora e significativa sem iniciar essa transformação em mim e, por conseguinte, nas estratégias ecopedagógicas de minhas práticas docentes? A terceira margem, portanto, é o local onde a escuta sensível pode ser feita, local onde os ruídos ecoam ao percorrer os caminhos de dentro. É o local das origens, sonhos e realizações, da busca de sentidos integradores da existência, de conexões entre os caminhos, de pertencimento. A pesquisa implicada me permite permanecer na terceira margem, tendo o rio, a canoa e o remo como conexão entre o real e o imaginário humano, inseridos no ethos e no habitus dos nossos pertencimentos. Com Macedo (2012, p. 25), procuro compreender melhor esse percurso. Ele cita Barbier ao falar a respeito da pesquisa implicada explicando que:

Para Barbier, reconhecer a implicação histórico-existencial é levar em conta o ethos e o habitus dos nossos pertencimentos. Escreve esse autor que é pouco provável que o pesquisador oriundo de uma classe popular considere

\footnotetext{
${ }^{21}$ ROSA, Guimarães. Primeiras Estórias. Editora Nova Fronteira - Rio de Janeiro, 1988, pág. 32. Disponível em: <http://www.releituras.com/guimarosa_margem.asp>. Acesso em: 18 fev. 2016, às 18h40min.
} 
os fatos sociais de maneira semelhante à de um da classe abastada. Segundo ele, essa diferença de perspectiva se ativada, ideológica e reflexivamente, pode fornecer esclarecimentos surpreendentes e reveladores do objeto estudado.

[...] Eis porque, segundo Barbier, devemos encontrar na implicação histórico-existencial a noção de práxis e projeto, entretecendo aí implicações psicoafetivas e se for o caso, implicações estruturo-profissionais, densamente presentes na práxis docente por exemplo.

Esses elementos que apresento são remo de minha embarcação e prossigo neste percurso navegando pela terceira margem do rio, expondo as passagens que as suas águas me fizeram envolver. A terceira margem é a própria lógica do terceiro incluído manifestada pela prática da transdisciplinaridade, ao que Nicolescu (2000, p. 142-143) explica que

Ao fluxo de informação que atravessa de maneira coerente os diferentes níveis de realidade corresponde um fluxo de consciência atravessando coerentemente os diferentes níveis de percepção. Os dois fluxos são interrelacionados porque eles compartilham a mesma zona de não resistência. Conhecimento não é nem exterior nem interior: ele é simultaneamente exterior e interior. Os estudos do Universo e do ser humano sustentam um ao outro. A zona de não resistência desempenha o papel do terceiro secretamente incluído que permite a unificação do Sujeito transdisciplinar e do Objeto transdisciplinar, sem que haja a supressão de suas diferenças. (Grifos do autor)

O momento de encontro do nosso grupo na sala de aula geralmente era alegre e festivo. Havia muita conversa, risos, o encontro estimulava as manifestações espontâneas e descontraídas. A transdisciplinaridade brotava naturalmente por meio dessas manifestações, elas faziam parte de uma contextualização que atualizava o conhecimento do conhecimento existente naquela realidade, tematizando e resultando no envolvimento de atividades de leitura e escrita. A experiência de vida, o conhecimento que cada um trazia era o que alimentava as trocas, a inclusão, o pertencimento.

Figura 30 - Encontro ruidoso

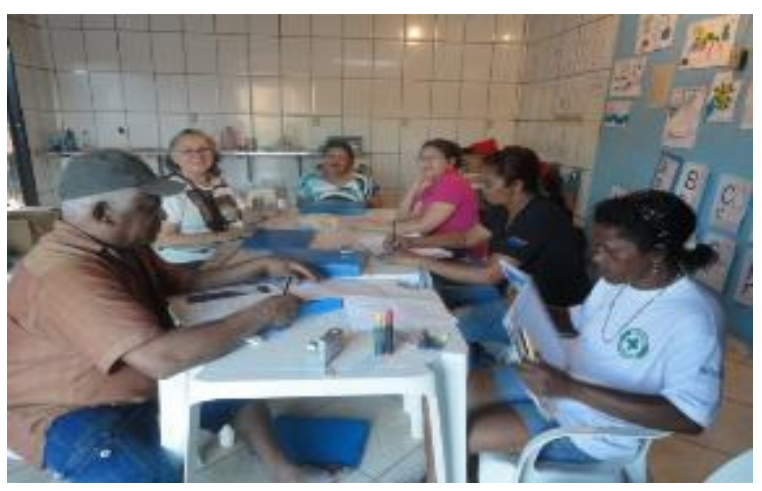

Figura 31 - Ruídos do encontro

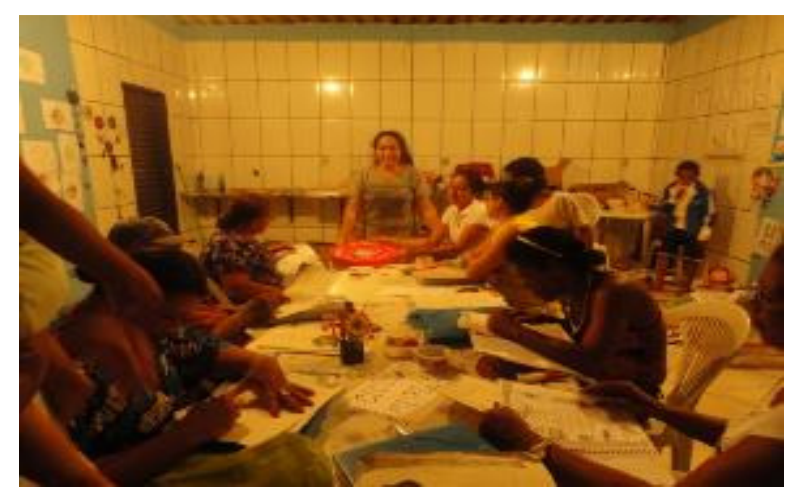

Fonte: Acervo da pesquisa. Ano: 2014. 


\subsection{O ruído das águas movimentadas no caminho}

O percurso desta pesquisa, conforme o que já foi exposto desde o memorial apresentado, tem seu início em tempos distantes de minha existência. Mais distantes, ainda, quanto mais me percebo síntese da vida do cosmos, feita do mesmo pó do qual é constituído o universo, encontrando sentido para a minha existência na conexão com outras existências e vidas que habitam nosso planeta. Essa busca de sentido é uma construção que vem se fazendo em mim, agora mais intensamente, na soma de tempos e distâncias que encontram lugar para se prolongar nos caminhos da educação.

Como professora da rede pública municipal de Goiânia, atuando em escola da periferia da cidade, atendendo, em um turno, à demanda dos adultos trabalhadores-alunos e, em outro, à demanda dos filhos desses adultos trabalhadores-alunos, fui conhecendo essa realidade por dentro e me encontrando no encontro com esses sujeitos. Criando estratégias para me aproximar de suas realidades, me aproximava da EA ao inventar passeata pela água, excursão ao Rio Meia Ponte, caminhada contra a dengue, na comunidade do entorno da escola municipal onde trabalhava. Na sala de aula, ao ver o planeta Terra como nossa morada, ao falar do lixo, do cuidado com a natureza e fazendo poesia com os alunos. O envolvimento com as dificuldades para o atendimento a essas demandas me lançou nessas águas como pesquisadora. Desde as especializações, depois no mestrado e agora no doutorado, vou me percebendo cada vez mais habitando a "terceira margem do rio".

Em 2013, já desenvolvendo a pesquisa do doutorado, que envolvia os catadores, a EA e a EP, iniciei os primeiros contatos para a constituição do campo de pesquisa. Tinha informação acerca da existência da Incubadora Social da UFG e de sua atuação junto às cooperativas. Desde o primeiro contato com essa Incubadora fui recebida com entusiasmo, pois fazer a alfabetização dos catadores era uma ação prevista em seu projeto, todavia sem conseguir implementá-la. Por meio dessa incubadora iniciei o contato com as cooperativas a ela vinculadas. Nesse momento inicial, tinha como objetivo confirmar a existência da demanda de adultos alfabetizandos e, com essa finalidade, percorri as cooperativas vinculadas a essa Incubadora, aplicando um questionário para a coleta de informações acerca da escolarização dos catadores. Por esse levantamento, constatei um grupo de 23 catadores que não sabiam ler e escrever, localizado, em números diferentes, nas 7 cooperativas vinculadas à incubadora. Ao retornar às cooperativas, esse número aumentou para 30 alfabetizandos, alguns porque não estavam no dia que eu fiz a visita, outros porque só depois ingressaram na cooperativa. 
O desejo inicial era poder atender todos os cooperados alfabetizandos, constituindo uma turma com todos eles, mas as condições concretas da distância entre as cooperativas, o trânsito, o tempo de deslocamento para ir e voltar, o cansaço depois de um dia de trabalho, além da dificuldade de um veículo para o transporte de todos, me fizeram perceber a impossibilidade de viabilizar essa turma com todos juntos. Não foi fácil aceitar essa realidade, depois de ter conhecido de perto e alimentado o desejo de cada alfabetizando de poder aprender a ler e escrever, e agora ter que dizer a eles que não serão atendidos por essa turma. Foram excluídos mais uma vez. Tive que tomar a decisão de organizar a turma somente com 2 cooperativas, as que estavam com maior número de alfabetizandos. Assim, atenderia os catadores da Acop e da Coocamare, com 8 alfabetizandos em cada uma delas, em uma sala situada no prédio da Incubadora Social da UFG. Telefonei para todas as cooperativas por onde eu havia percorrido, para informar sobre a formação da turma e convidei os alfabetizandos, que tivessem como se deslocar, para participar da turma.

Como a turma seria vinculada ao Programa AJA-Expansão, precisava cumprir algumas diretrizes apresentadas e, dentre elas, a de ter no mínimo 15 educandos para a abertura da turma. A vinculação da turma ao programa institucional de alfabetização da SME de Goiânia, foi uma opção tomada desde o início da elaboração do projeto, pois esse Programa já existe há mais de 10 anos, sem nunca ter sido tomado como objeto de investigação. O Programa AJA-Expansão da SME de Goiânia foi uma parceria importante, especialmente por fortalecer o caráter institucional e enriquecer a pesquisa incluindo-a em sua experiência e, por esse meio, no Programa Brasileiro de Alfabetização (PBA). Com esse vínculo, também ela recebeu os subsídios públicos e pôde contar com um educador popular.

As cooperativas envolvidas na pesquisa são ligadas à Incubadora Social vinculada à Pró-Reitoria de Extensão e Cultura da Universidade Federal de Goiás (UFG). O Programa AJA-Expansão, a Incubadora Social da UFG e as cooperativas se tornaram parcerias importantes para a efetivação do trabalho. Goiânia possui atualmente 15 cooperativas que recebem os resíduos sólidos da coleta seletiva de toda a cidade. Destas, 8 cooperativas são vinculadas à incubadora social da UFG e, dentre elas, inicialmente 2, a Acop e a Coocamare, foram as cooperativas envolvidas no projeto, por apresentarem maior demanda de alfabetizandos. Decisão tomada após um longo percurso de visitas e conversas para o levantamento da demanda de adultos que não sabiam ler e escrever nessas cooperativas. Essas cooperativas trabalhavam em regime de cooperação, com estratégias de estruturação interna a partir dos princípios da autogestão. São acessíveis, abertas ao diálogo e o seu conjunto 
apresenta a demanda buscada para a efetivação desta experiência, ou seja, nelas foram localizados 30 catadores que não sabiam ler e escrever.

Por já estar com um espaço físico adequado para a instalação da turma, no próprio prédio da Incubadora, e com a demanda dos alfabetizandos já confirmada e localizada, parti para fazer o cadastro da turma junto ao Programa AJA-Expansão, mesmo ainda não tendo conseguido um transporte para conduzir os alfabetizandos até o local onde a turma seria instalada. Sob a autorização desse programa, organizei a turma em dois grupos e comecei o atendimento, o trabalho precisava acontecer imediatamente, agora que a turma já estava cadastrada. Então, iniciei o atendimento do grupo da Coocamare na própria cooperativa, enquanto organizava o grupo da Acop e lutava por um veículo para conduzir os educandos. Mas a experiência vivida com os alfabetizandos da cooperativa Coocamare, em duas semanas de atendimento, me fez perceber que, para efetivar a alfabetização de catadores, existem muitas pedras nesse leito que precisam ser contornadas para que o processo aconteça. Em contraposição a todo o meu desdobramento para atender às exigências do Programa e ao desejo de fazer uma intervenção significativa, não consegui, em nenhum dia, reunir todo o grupo dos alfabetizandos. Por razões diversas, cada um tinha um motivo para não comparecer, alguns nem se dispuseram a frequentar a turma mesmo estando na cooperativa e outros porque foram trabalhar em outro lugar devido à greve da coleta seletiva.

Alguns educandos, trabalhadores da Coocamare, manifestaram que não queriam que a turma saísse da cooperativa. Essa situação me levou a repensar uma maneira de melhor poder atender as condições colocadas por esse grupo. Assim, após o cadastro de cada aluno para que a turma fosse cadastrada no Programa, admiti que seria melhor estruturar essa turma organizada em dois grupos, um em cada cooperativa, com o atendimento nas próprias cooperativas. Mais uma vez tive que me adaptar às contingências da realidade apresentada. Nasceu um sentimento de perda pela quebra dos meus planos, pois o espaço físico ofertado pela Incubadora proporcionaria qualidade ao trabalho realizado. Consegui recompor-me e prosseguir navegando por essas águas, lembrando-me dos princípios da recursividade, da imprevisibilidade e impermanência das coisas e do movimento em espiral inspiradores da teoria da complexidade.

Recolhi os ensinamentos dessa experiência, refiz o percurso e segui adiante procurando acompanhar a força do fluxo das águas. Assim, procurei ver que em dois grupos não dependeriam de transporte, não haveria perda de tempo no deslocamento, a atividade poderia se iniciar e finalizar mais cedo. Além disso, haveria o contato direto com duas comunidades de catadores que enriqueceriam os dados da pesquisa e ampliariam o espaço de 
intervenção. Programaria visitas e excursões ao longo da formação, que proporcionassem momentos de encontro, partilhas e convivência entre os dois grupos.

Pensei nos detalhes para a estruturação dos dois grupos, pois muitas condições precisariam ser garantidas. A primeira seria o cadastro de um educador popular. $\mathrm{O}$ levantamento feito indicou que na Coocamare havia dois cooperados com o ensino médio e ambos se candidataram a ser educador popular da turma. Mediante o fato de que somente um poderia ser cadastrado, decidiram entre eles e fizeram a escolha, então, para incentivar a participação, convidei o outro para que fosse um educador voluntário e eu assumiria a sua ajuda de custo. Com a turma organizada em dois grupos, era necessário um educador popular em cada grupo. No contato com a Acop, vi que não havia nenhum catador com o ensino médio, mesmo assim, a própria presidente, com ensino médio incompleto, se candidatou e a Incubadora Social da UFG assumiu uma bolsa para a sua remuneração.

A cidade de Goiânia estava vivendo um momento de grande crise políticoadministrativa. Essa crise estava afetando toda a coleta de lixo da cidade e, especialmente, a coleta seletiva. Isso gerou uma crise também nas cooperativas, devido à drástica redução do material. Em consequência, muitos cooperados tiveram que sair em busca de outros serviços. Assim, o movimento era intenso entre os sujeitos envolvidos neste campo de pesquisa. Não consegui efetivar o cadastro do educador popular da Coocamare, ficou faltando o certificado de conclusão do ensino médio, mas combinei de levar depois. No dia 09/06/2014, a outra educadora popular me ligou pra comunicar que, com a greve, o colega catador educador popular havia saído da cooperativa, estava trabalhando em outro lugar e o horário não conciliava mais. Todos os dias eu respirava profundo e me preparava para viver o novo dia, contornando as novas pedras do caminho.

$\mathrm{Na}$ cooperativa Coocamare, mesmo atendendo as solicitações desse grupo, na terceira semana, somente um catador ainda permanecia no grupo, os alunos que estavam frequentando saíram uns em busca de outros serviços, em decorrência da greve, e outros, talvez, por não terem encontrado em si mesmos o lugar para essa formação. Tive que encerrar o atendimento a esse grupo. Estimulei o único educando que restou e orientei para que se matriculasse em uma escola da rede municipal, pois percebi que ele já tinha boa noção de leitura e escrita e condições de continuar sua formação em uma turma do ensino regular da EAJA. Emocionado, ele lamentou que a turma terminasse. De imediato, não consegui entender o que havia se passado para que os educandos não permanecessem, aos poucos, fui procurando encontrar explicações. Vi uma soma de elementos que podem ter contribuído para o esvaziamento da turma, elementos dos caminhos externos e dos caminhos de dentro de cada um. De um lado a 
greve, a necessidade de buscar trabalho em outro lugar, de outro lado o distanciamento ao mundo da leitura e da escrita, a descrença no aprendizado. Somando-se a esses fatores, encontrei ainda outros, associados ao ambiente proporcionado pela cooperativa e à falta de um espaço físico adequado.

Após percorrer todas as cooperativas incubadas, fui percebendo o quanto a estrutura e o cuidado com o espaço físico fazem diferença na criação do ambiente de convívio e trabalho da cooperativa. Até mesmo o relacionamento interpessoal é, em grande parte, influenciado por esse ambiente onde todos convivem. Observei que o espaço físico da cooperativa Coocamare estava todo tomado pelos resíduos sólidos, parecia não haver separação entre o ambiente de convivência humana e o lugar dos resíduos, tudo se misturava. Em todos os cômodos da casa guardavam coisas recolhidas dos resíduos. Água parada. Água parada gera doença, morte. Ao ver as condições subumanas como um catador morava na varanda da casa, num barraco de tábuas e papelão, misturado ao acúmulo de resíduos que ele guardava e aos ratos, percebi que ele já não distinguia mais o que era viver na dignidade de um ser humano. Misturava-se indistintamente aos rejeitos, demonstrava ser ele, afinal, o maior daqueles rejeitos. Vi ali o cenário que o poeta cantou em sua poesia: "O bicho não era um cão, não era um gato, não era um rato. O bicho, meu Deus, era um homem". Bandeira ${ }^{22}$ (2002) A minha percepção desse lugar foi se modificando na medida em que eu fui me aproximando e conhecendo melhor os recantos daquele espaço. Apreendi que nas sombras daquelas frondosas mangueiras, materialização da natureza mãe, havia o acolhimento também a uma realidade de degradação humana ocultada, incorporada e naturalizada ao convívio daquelas pessoas.

A sala onde a turma estava sendo atendida era pequena, sem ventilação, a única janela que tinha era tampada por um grande quadro de avisos. Era a mesma sala do escritório da cooperativa, portanto, ela tinha que ser organizada todos os dias para que pudéssemos realizar as atividades e no final da aula tudo tinha que ser recolhido novamente. Enquanto trabalhávamos na turma, um grupo de catadores se reunia na varanda, do lado de fora da sala, conversando, escutando música e tomando cerveja. Considero que todos esses aspectos contribuíram para a falta de ambiente adequado e fortalecimento da experiência naquele ambiente. Essa cooperativa me comoveu pelo tanto que ela estava necessitada de uma intervenção que valorizasse a vida, encontrasse a beleza, despertasse a dignidade, promovesse

\footnotetext{
${ }^{22}$ O Bicho. Manuel Bandeira. Disponível em: <http://www.elfikurten.com.br/2011/02/manuel-bandeira-estrelada-vida-inteira.html>. Acesso em: 09 mar. 2016.
} 
a ecologia humana. Fizemos algumas rodas de sensibilização, nelas, todos os que se encontravam na cooperativa àquela hora se juntavam, mesmo os que não eram da turma. Era o início de uma abordagem de ecologia humana, os comentários indicavam que eles gostavam dessa roda.

Figura 32 - As primeiras lições

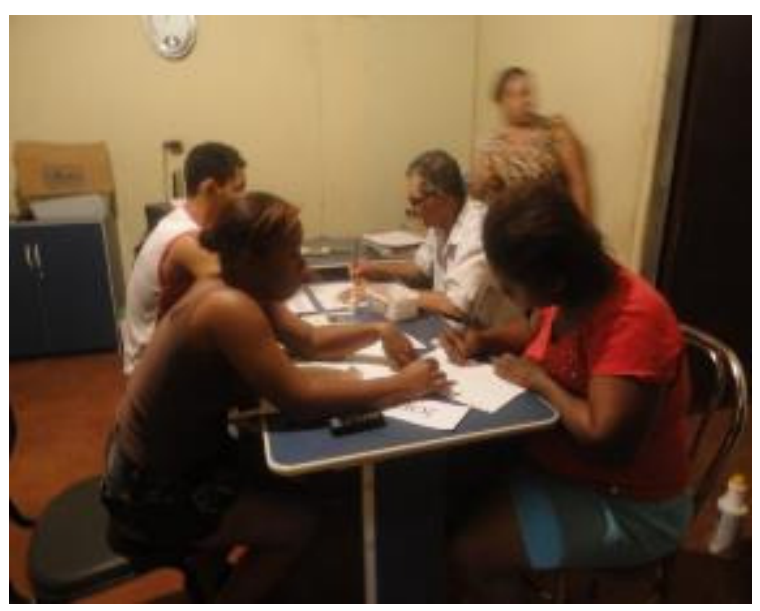

Figura 33 - Roda de delicadezas

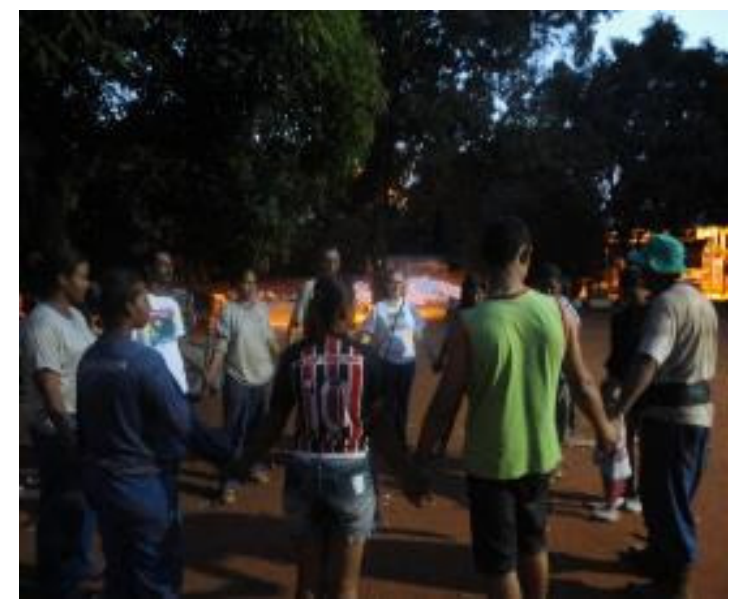

Fonte: Acervo da pesquisa. Coocamare. Data: Abril de 2014.

Assim, tivemos momentos bons nas conversas de nossos encontros, nas memórias das histórias de vida que construímos. Em uma aula, eu havia levado um atlas bem grande e uma aluna se pôs a olhar admirada as constelações das estrelas no céu, depois perguntou se elas existiam de verdade. Com a minha confirmação, ela disse que agora ia passar a olhar as estrelas no céu. Uma fala carregada de sentidos, para ela e para mim, uma sinapse, fiquei contente. Quem olha para o céu, para uma noite estrelada, olha para si mesmo em cada ponto de luz do firmamento e percebe o seu pertencimento como ponto de luz que habita o cosmos. Esses são caminhos sutis por onde a EA transita e vai fazendo diferença na constituição do ser. No dia 10/06/2014, encerrei as atividades naquela cooperativa, encerrei o contrato com os educadores populares, foquei o atendimento no grupo da cooperativa Acop e cadastrei a mim mesma como educadora popular da turma junto ao AJA-Expansão.

O Programa AJA-Expansão está diretamente vinculado ao Programa Brasil Alfabetizado. Este último está assentado em diretrizes que regulamentam e orientam as parcerias exclusivamente com as secretarias de educação dos municípios, estados e Distrito Federal. Estas elaboram seus planos e metas de acordo com a necessidade local. É um programa criado desde 2003 com a intenção de oportunizar a todos os jovens, adultos e idosos do Brasil o processo de alfabetização. Ele está fundamentado na perspectiva de educação e aprendizagens ao longo da vida, um conceito que vem se consolidando nas Conferências Internacionais de Educação de Adultos. 
As Conferências Internacionais de Educação de Adultos (Confinteas), promovidas pela Organização das Nações Unidas para a Educação, a Ciência e a Cultura (UNESCO), têm o objetivo de debater e avaliar as políticas implementadas para a modalidade de educação de adultos no mundo. São realizadas de 12 em 12 anos, desde 1949, e a VI Confintea, realizada no Brasil, em 2009, aprova em sua plenária final o Marco da Ação de Belém, em alusão à cidade que o sediou, a capital do Pará. Na apresentação desse documento está posto que "O grande desafio agora é o de passar da retórica à ação, envidando esforços para que as recomendações apresentadas no Marco da Ação de Belém sejam implementadas nas políticas públicas da educação de jovens e adultos.” (BRASIL, 2010, p. 3)

Conhecendo a realidade da educação de adultos, por dentro da realidade da rede pública onde atuei por mais de 25 anos e, agora, por dentro da realidade dos catadores que participaram desta pesquisa, vejo que permanece a distância entre a escola e a vida dos adultos educandos trabalhadores e daqueles catadores. Permanece também a distância entre as discussões e a ausência da escola na vida desses sujeitos, um distanciamento que se mantém mesmo depois de mais de 60 anos de Confintea. Diante do que já vi e conheci e aprendi em minha longa atuação como professora na rede pública e continuo aprendendo, agora com a realidade dos catadores de Goiânia, já não tenho mais tanta certeza sobre qual é a maior necessidade no momento. A necessidade de mais política pública ou a de mais compromisso de toda a sociedade civil e, em especial, dos gestores e autoridades representantes do poder público para com a escolarização de todos esses sujeitos. O que o contexto atual revela é que é preciso olhar para o drama da realidade ambiental de nossas cidades e valorizar a categoria dos catadores pela relevância de sua função na sustentabilidade da vida, como ponto de partida para a reconstrução do mundo.

As lacunas estão postas e próximas de nós, precisamos lançar o olhar em várias direções. Em diferentes espaços é feita a referência ao meio ambiente e à sustentabilidade nos documentos da Confintea, assim como no PNE, mas, ainda assim, permanece a necessidade de articulação e diálogo com a Educação Ambiental. A necessidade de fortalecer a EA como um campo epistemológico transdisciplinar que se assenta nos princípios de uma educação transformadora, integradora, holística, de formação do ser enquanto membro de uma sociedade que se articula e se sustenta pela relação direta com a natureza.

A persistência para a superação dos obstáculos expõe o distanciamento, descaso e até falta de interesse em atender, com a qualidade, o cuidado e a atenção que a situação requer as necessidades para a constituição de uma turma de alfabetização de adultos trabalhadores de cooperativa de catadores. Essa situação se acentua ainda mais quando se deseja que essa 
turma possa atender não somente às exigências das diretrizes dos programas, mas principalmente quando se deseja que ela possa corresponder a um ensino que seja transformador, de qualidade e satisfaça à especificidade da realidade envolvida, na efetivação da educação como direito de todos, alimentando sonhos, concretizando aspirações.

\section{3 Águas da experiência vivida lançadas em mandalas se abrindo em flor}

A definição da pesquisa na comunidade da cooperativa Acop não foi uma definição feita a priori, ela surgiu do contexto apresentado a partir dos dados resultantes do levantamento sobre a escolarização dos catadores e das reais condições que foram sendo construídas a partir do contexto daquela realidade. De toda a experiência realizada, muitos elementos foram surgindo e se interconectando, pois foram originados a partir do estudo feito de uma experiência realizada em uma única comunidade. A efetivação dessa experiência demandou diversas ações na busca de um trabalho de alfabetização que fosse uma expressão da vida dos educandos catadores que se dispuseram a colaborar com o estudo.

Os elementos que se despontaram a partir do contexto estudado trouxeram abertura para a possibilidade de diversas compreensões. As narrativas são o caminho por meio do qual faço as análises descritivas e interpretativas do conteúdo, relacionando os dados, entrecruzando informações a partir de grandes unidades de análise definidoras do conteúdo e da forma. Neste estudo se despontaram a Educação Ambiental, a Educação Popular, a alfabetização de catadores, os resíduos sólidos e as cooperativas de catadores de materiais recicláveis como unidades significativas articuladoras dos dados e capazes de responder às questões da pesquisa, ampliando o conhecimento sobre o assunto. Essas unidades e suas articulações se originaram apoiadas em um contexto social e no referencial teórico de sustentação deste estudo, que parte do princípio de que "A vida é gerada em rede de relações encadeadas. Tudo está conectado com tudo". (Diário de campo)

\subsubsection{Grupo cooperador}

Inicio a narrativa da pesquisa realizada, a partir do grupo de educandos que participaram da experiência. Eles foram os parceiros mais importantes para a pesquisa, juntos realizamos a experiência. Seria impossível responder as questões da pesquisa para saber "qual a contribuição da Educação Ambiental para uma aprendizagem significativa na alfabetização de adultos trabalhadores de cooperativas de resíduos sólidos e de que forma as estratégias ecopedagógicas podem contribuir para a formação humana emancipatória de alfabetizandos 
trabalhadores de cooperativas de resíduos sólidos", sem a participação desses colaboradores e de toda a comunidade que me acolheu. A relação com esses educandos permitiu uma aproximação com a vida vivida naquele lugar, portanto, eles tiveram uma contribuição relevante ao mostrarem como é a vida daquele grupo de catadores e de que maneira pode o catador participar de uma turma de alfabetização. Uma contribuição que nos faz pensar em como pode ser uma turma para esses catadores.

A turma ficou constituída por 11 educandos que frequentaram os encontros, sendo 5 com frequência regular ao longo de toda a pesquisa e 6 que frequentaram de maneira irregular. Todos esses educandos participaram, embora de maneiras diferentes, cada um como pôde. Era um movimento de águas que iam e vinham se revezando no sustento da vida daquela turma. Tinham uma média de 50 anos de idade, eram todos nordestinos e trabalhavam na roça antes de virem para a cidade. Em roda de conversa, teve dia de falarem sobre a vida na roça, contando das dificuldades, do tanto que tinham que trabalhar. Maria F contou de ter que ficar o dia inteiro vigiando plantação de arroz para não deixar os passarinhos atacarem, usava badoque pra isso, e que também pegava firme na enxada desde cedo. Maria A desde criança cozinhava e caminhava bastante com uma bacia de comida na cabeça pra levar para os trabalhadores na roça. Eram 12 irmãos, que as vezes passavam fome por não ter o que comer em casa. Quando o pai adoecia, faltava comida em casa. Depois, o pai morreu e tiveram que procurar viver na cidade. Parou de estudar porque um colega furou o outro com o lápis e a professora a acusou, injustamente, de ter feito isso, não deixou ela explicar e se defender, e a suspendeu da aula por 15 dias. O pai nunca mais deixou ela voltar pra escola. Quando perguntei, disseram que mesmo com toda a dificuldade que existe, ainda assim, é melhor viver na cidade, tem mais oportunidade pra trabalhar.

Maria F tem 58 anos, nasceu em São Desidério, BA. É separada do marido, tem um namorado que está vivendo com ela. Disse que o marido largou ela pra viver com uma mulher novinha, que ele agora tá com filho pequeno ainda. Desse casamento, Maria F tem dois filhos casados, uma netinha e um netinho. Trabalha na cooperativa Acop, mas diz que não é catadora, que ela é cooperada, que quem era catador nas ruas hoje é cooperado e que não gosta de ser chamada de catadora. Ela se juntou ao grupo dessa cooperativa ainda quando moravam na favela, ela trabalhava como doméstica ou como diarista nas casas das famílias. Dizia que a honestidade é a maior riqueza que uma pessoa tem, que ela sempre trabalhou pra sustentar os filhos e que ensinava isso a eles, que eles tinham que ser corretos, não pegar nada que fosse dos outros e não pedir comida na casa de ninguém. 
Maria $\mathrm{F}$ foi uma grande companheira que eu tive nessa comunidade, na primeira aula ela não compareceu, no dia seguinte cheguei mais cedo e fui à sua casa. Conversamos, ela me falou umas coisas interessantes sobre a natureza das águas, dizendo que as águas enchem a nossa mão, mas não conseguimos retê-las, é a vida. É assim mesmo, é a natureza fluida incontível da vida. Disse que tem um netinho que vai nascer daí a um mês, mas que tá precisando de um berço e uma banheira, perguntou se eu teria como conseguir. Eu disse que ia ver se conseguiria. Ela passou a frequentar as aulas. Anunciei na igreja que frequento e no outro domingo recebi um bercinho e uma banheira usados, mas novinhos, o bercinho, tipo chiqueirinho, ainda na caixa original, a banheira sem nenhum arranhãozinho, pouco usada. Maria F ficou muito contente, disse que nem os filhos dela, nem a outra netinha nunca tiveram um bercinho tão lindo. Todas as tardes, assim que eu chegava, ela ia logo para a sala ficar comigo, sempre banhada e arrumada especialmente para a ocasião, dizia que não era bom eu ficar sozinha ali. Enquanto eu organizava a sala, ela ia conversando e me contando as coisas que se passavam na comunidade e dizia: "Professora, aqui não acontece nada que eu não fique sabendo". Foi ela quem me apresentou Maria P. Tenho especial carinho e gratidão a ela. No último dia de atividade, ela chorou durante todo o tempo da celebração que fizemos.

Maria A tinha 34 anos, nasceu em Poção das Pedras, no Maranhão. Veio para Goiânia adolescente, morou vários anos na casa de uma família onde vivia e trabalhava, por conta do abrigo e proteção que recebia. Depois saiu dessa casa, morou com uma irmã, até se casar. Tem vontade de ser mãe, mas não pode engravidar. Já pensou em adotar uma criança, mas o marido ainda não tinha aceitado a ideia. Não era casada oficialmente, tinha relação estável e se dizia casada. Ela não era catadora, morava na rua dos fundos da rua onde ficava a sala de aula, foi o seu marido que passou pela porta da sala na hora da aula, parou, conversou conosco e falou que ia chamar a sua esposa para se matricular na turma. No dia seguinte ela começou a frequentar as aulas, já era conhecida pelos colegas da turma, mas não era frequentadora da região onde ficava a cooperativa. Começou a frequentar a turma desde o início do mês de agosto. No início do mês de outubro Maria A parou de frequentar a turma. $\mathrm{O}$ grupo combinou e um dia fomos até sua casa para falar com ela, mas não encontramos ninguém. Outro dia fui sozinha, o esposo me recebeu, ela estava tomando banho, então ficamos conversando enquanto a aguardava. Ele me falou que ela teve um problema de saúde, uma inflamação do fígado e que estava em tratamento. Ela apareceu, me abraçou com emoção, conversamos, falei que a turma tinha ido visitá-la e que a estávamos aguardando de volta. Ela disse que ia voltar, mas nunca mais apareceu. 
Maria $\mathbf{P}$ foi uma educanda muito assídua na turma e que teve um bom desenvolvimento da leitura e da escrita. Finalizou as atividades conseguindo ler e escrever. Ela tinha 35 anos, nasceu em Ouricuri, no estado de Pernambuco. Já veio para Goiânia casada, era catadora, trabalhava na Acop e morou 5 anos na favela do trilho de trem. Recebeu uma casa, na comunidade do Setor Albino Boaventura, onde morava junto com os outros catadores. Tinha 7 filhos, dois ela teve enquanto morava na favela e a mais novinha, de 1 ano, que ela levava para a turma todos os dias, já nasceu naquela comunidade. $\mathrm{O}$ esposo era pedreiro, ele chegou a se matricular na turma, mas nunca frequentou. Maria P fez uma horta em seu quintal e disse que aprendeu a olhar para as plantas depois que entrou para essa turma.

(15) Antes das aulas a gente passava por cima do córrego e nem olhava pra baixo. Até das plantas mesmo também. Não, mas agora eu tô cuidando, agora eu quero é plantar planta mesmo. [...] Fez mudar dentro de mim, porque agora eu tenho cuidado com as plantas. Antes eu não tinha mesmo não. Eu nem ligava, mas agora não. Assim de ver e dizer, ah essa planta eu vou cuidar e tal agora, mas antes eu não tinha isso não, mas agora eu tenho.

Maria P expressou, assim, as mudanças que ocorreram com ela decorrentes das intervenções realizadas por meio das estratégias da EA. Mudanças que ocorreram em diferentes níveis e que farão com que Maria $\mathrm{P}$ passe a se relacionar de outra maneira com o meio com o qual convive. Uma mudança que a conduzirá a perceber o sentido da vida, o sentido de sua existência, o pertencimento, pois ela fala que ocorreu uma mudança dentro dela mudando a sua maneira de se relacionar com a natureza e com o mundo. as suas ações e conta como essas mudanças se manifestaram.

Maria M foi uma aluna muito especial, por quem eu tenho muita admiração e gratidão. Ela nasceu em Santa Inês, no Maranhão, tinha 44 anos e 12 filhos. Contou que teve a primeira filha com 10 anos, quando ainda vivia com os pais. O pai da criança tinha 29 anos e foi quem criou a filha. Aos 14 anos teve o segundo filho com esse mesmo companheiro. Ela nunca se casou. Morou em outras cidades do Maranhão antes de vir pra Goiânia e continuou tendo filhos com outros companheiros. Perguntei e ela disse que queria fazer uma cirurgia para não engravidar mais, cheguei a me informar e soube que no caso dela a cirurgia é feita rapidamente pelo SUS. Conversei com ela, orientando para que tomasse as providências, mas ela não demonstrou preocupação com isso, disse que depois ia ver. $\mathrm{O}$ seu filho $\mathrm{C}$, que tinha 10 anos, a acompanhava na turma, porque ele estudava na escola municipal mais próxima dessa comunidade. Ela o trouxe para perto porque ele havia sido expulso da escola do bairro onde moravam. Maria M morava no bairro Jardim Cerrado III, em uma casa que ela havia recebido 
do governo. Saía de casa de madrugada e pegava o ônibus para C estar na escola e ela na Cooperativa às $7 \mathrm{~h}$. Dizia sempre que amava ser catadora e que queria montar uma cooperativa no seu bairro. Desenhou a casa dela sendo uma cooperativa, com um caminhão deixando os resíduos. Em 2015, quando estive novamente na comunidade, me contaram que ela havia montado uma cooperativa no Jardim Cerrado.

Maria S era mãe de Naná. Nasceu na cidade de São Julião, no Piauí. Cresceu na lida da roça. Depois de casada, veio para Goiânia onde trabalhou como catadora nas ruas da cidade. Tem 3 filhos adultos, Naná era a filha do meio, o mais novo pintou a nossa sala e o mais velho é catador da Acop. O esposo também sempre foi catador e trabalha na Acop, se cadastrou na turma, mas nunca frequentou. Seus filhos estudaram até o ensino fundamental. Desde cedo aprenderam a ser catadores também. Se inscreveu na turma desde o início e começou a frequentar ainda no galpão da cooperativa. Participou de algumas aulas na varanda, mas depois sumiu. Naná me disse que ela saiu da cooperativa, estava procurando serviço em outro lugar e por isso tinha parado. Dia 14 de julho ela retornou. Estava trabalhando em uma empresa recicladora de sacolinhas de plástico. Ela trabalhava no setor que recebia as sacolinhas. Disse que era muito difícil porque tinha muita podridão. Frequentemente ela exalava o cheiro dessas sacolinhas, porque vinha direto para a sala, mas disse que tava bom porque tinha um contrato e um salário certo pra receber.

No final do mês de novembro, após receber o salário, ela saiu do serviço e ficou sem trabalhar. Observei que ela trabalhou quando precisou de dinheiro para pagar as contas e comprar comida. No final do ano, as pessoas daquela comunidade costumam receber algumas cestas de alimentação de Ongs, pessoas civis e instituições de caridade. Quando ela recebeu o salário de novembro, saiu do emprego e ficou sem trabalhar. Lembrei-me de Arendt (2008) ao refletir sobre o trabalho e a condição humana. Maria S me confirmava, o homem não trabalha porque ama trabalhar, ele trabalha porque a condição humana o obriga e a condição degradante do trabalho de Maria S a fazia trabalhar esporadicamente, quando a necessidade obrigava.

Maria R frequentou a turma por pouco tempo. Se matriculou no dia 01/11/2014 e frequentou até a $1^{\mathrm{a}}$ semana de dezembro, foi Maria M quem a convidou. Ela era avó de $\mathrm{C}$, o filho de Maria M que a acompanhava. Maria R tinha 58 anos, nasceu em Barra do Corda, no Maranhão. Disse que estava muito contente por estar estudando, que ela sempre teve vontade de aprender a ler e escrever e que não começou antes porque não sabia daquela turma. Ela trabalhava como doméstica no Setor Oeste e morava em um setor próximo do Setor Boaventura. Disse que a dificuldade era chegar na hora da aula, porque trabalhava muito 
longe, pegava mais de um ônibus e tinha dia que saía tarde do serviço. Ela já conhecia as letras e conseguia formar sílabas. Participou de momentos importantes da formação na turma, quando trabalhamos sobre os cuidados com a água que bebemos e gostou de fazer o teste de saída que o AJA-Expansão enviou.

Maria W tinha 44 anos, nasceu em São Domingos, no interior do Pará. Ela foi uma pessoa muito acolhedora à nossa turma. Participou com assiduidade enquanto estávamos no galpão, depois, mesmo quando estávamos na varanda de sua casa, não teve mais assiduidade. Seu esposo logo se acidentou e a partir daí ela não acompanhou mais a turma. Ela disse que não tinha terminado o fundamental, mas que precisava treinar a leitura um pouco mais. Tinha dois filhos já adultos, vivia com um companheiro já há bastante tempo e se identificava como casada. Foi esse companheiro quem a ajudou a criar os filhos, por quem tinham respeito e consideração de pai. Era separada do pai de seus filhos, ele bebia, brigava e batia nela. Ela era catadora e uma das fundadoras da Acop, veio para essa comunidade junto com o grupo que veio da favela. Já foi também presidente da Acop. Era muito amiga de Naná, confidentes. Percebi que elas sempre conversavam antes de tomar decisões importantes, parecendo se aconselharem e se ajudarem nesses momentos. Foi Maria W quem cedeu a varanda de sua casa para a instalação da turma, foi ela também quem emprestou mesinhas e cadeiras para a turma.

Seu J tinha 68 anos, nasceu em Coribe, no interior da Bahia. Trabalhava na roça, veio para Goiânia já adulto. Se tornou pedreiro e já estava aposentado pelo INSS. Era viúvo e morava só, seus filhos já estavam adultos. De vez em quando uma netinha passava na sala e lhe pedia a bênção. Disse que uma vez frequentou uma escola por 2 semanas e 3 dias. Sabia ler e escrever, mas contou que aprendeu sozinho, lendo jornal, juntando as letras. Era um conhecedor das plantas e dos chás e se revelou um grande contador de estórias, gostava de contar história para as crianças, era bem humorado e de vez em quando contava uma charada. Não era catador, mas morava na mesma comunidade desde que foi entregue para as famílias, trabalhou como pedreiro na construção daquelas casas e era bem integrado ao grupo.

Seu F tinha 63 anos, nasceu em Carinhanha, na Bahia. Veio pra Goiânia já casado. É casado com D. E, que se cadastrou na turma, assistiu às primeiras aulas, ainda no galpão, e desistiu. No final do ano Seu F me disse que ela me mandou um recado, que se arrependeu de ter saído, mas que se for ter a turma de novo ela vai voltar. Os filhos já são adultos, o mais velho é serralheiro e o mais novo é catador também e trabalha na Acop. Seu F foi um dos primeiros a se cadastrar na turma, mas somente no final do mês de setembro decidiu começar a frequentar. Ele contou isso assim: 
(16) Eu acreditei, agora eu não quis foi vim. Mas depois, eu me arrependi depois, que eu num vim. Se eu tivesse vindo ao menos desde quando eu entrei, tava mais, sabendo mais coisa ainda, mas depois foi caindo na ideia, sabe que eu devia ir? E eu conversando com o $C$ ali, $C$ me disse: Moço, porque você não vai estudar, rapaz? Mas depois ele foi falando, aí caiu a ideia minha. Sabe que eu vô? Aí eu via gente chegando lá, passando pra cá. Eu falei, vou passar lá, conversar. Eu pensei, professora. A mim eu me senti assim que se eu já tivesse vindo, pra mim seria melhor ainda, eu sabia mais.

Seu F era um cuidador ambiental. Naná me contou que ele limpava o lixo das ruas para não entupir as bocas de lobo, falava com as pessoas pra terem cuidado e mantinha uma horta na beirada de um muro que ficava em frente à sua casa. Ele era uma pessoa ponderada, sua presença impunha respeito na comunidade, uma referência de boas condutas, ao mesmo tempo, era bem humorado e muito interessado em aprender a ler e a escrever. Fizemos um trabalho de corpo e fiquei preocupada com a reação dele. Imaginei que ele poderia nem retornar mais, mas, no dia seguinte, ele chegou à turma me mostrando um livrinho que encontrou na cooperativa, que ensinava a fazer vários exercícios físicos. Foi grande o meu contentamento. Ele tinha facilidade para aprender as coisas, rapidamente aprendeu a escrever o nome, com uma boa coordenação motora fina. Considerei a vinda dele para a turma como uma confirmação de confiança, de fortalecimento de vínculos entre o meu trabalho e aquela comunidade.

Seu M era catador e trabalhava na cooperativa Acop. Tinha 80 anos. Nasceu em Carinhanha, na Bahia. É casado e vive com a esposa em uma casa bem em frente à cooperativa. É primo do Seu F. Se cadastrou na turma desde o início de 2014, junto com o primeiro grupo, mas não quis frequentar a turma. Somente no mês de outubro resolveu participar do grupo. Foi ele quem me sugeriu trabalhar naquela sala que alugamos. Quando chegou, disse que já estava muito velho para estudar e por isso tinha decidido não entrar para a turma. Recebê-lo na turma foi uma honra. Seu $\mathrm{M}$, àquelas alturas da vida, tinha todo o direito de ser respeitado em sua decisão de não querer estudar. A decisão de entrar para a turma era, então, uma expressão profunda da confiança depositada no trabalho que desenvolvíamos ali. Maior ainda quando ele contou que nunca tinha frequentado uma sala de aula. Disse que aquela era a primeira escola de sua vida. Rapidamente aprendeu a escrever o nome, ficou feliz. Assinou o seu nome no termo de consentimento da pesquisa. Estava interessado em fazer a consulta para ganhar os óculos. Liguei para a instituição e consegui ainda encaminhá-lo. Ele fez a consulta e foi encaminhado para fazer uma cirurgia de catarata. $\mathrm{O}$ ano terminou, mas ele me informou, satisfeito, que estava tudo encaminhado para o ano de 2015. 
F Catador participou da turma ao longo de todo o período, mas sempre de maneira muito irregular. Foi assíduo enquanto a turma estava no galpão. Ao passar para a varanda ficou sem frequentar, depois apareceu em algumas aulas e assim continuou frequentando a turma até o final das atividades. Uma tarde, ao chegar de carro na comunidade, passei devagar por F Catador que estava em pé, parado na rua. Absorto, ele nem me viu passar, entretido que estava tentando ler um jornal. Natural de Imperatriz, no Maranhão, F Catador tinha 39 anos, era casado, sua esposa era catadora, a tesoureira da Acop. Tinham 5 filhos. A mais velha era casada com o filho mais novo de Maria S, irmão de Naná, tinham uma filhinha. A filha mais nova de F catador era uma menina ainda bebê. Os outros eram dois meninos e uma menina, entre 6 e 10 anos de idade, que de vez em quando passavam pela nossa sala, sentavam na esteira no chão para brincar ou ficar conversando olhando os mapas grandes afixados na parede. Aqueles mapas eram uma atração para as crianças, que se sentavam no chão à sua volta e ficavam juntos conversando sobre o que viam ali, trocando saberes.

Maria Elizângela (a Naná) assinou o termo de consentimento me autorizando a utilizar o nome dela na pesquisa. Ela foi minha assistente durante o trabalho na turma, mas, mais importante que isso, foi um elo significativo para a minha relação com aquela comunidade. Ela nasceu em Goiânia e tinha 24 anos, era a filha do meio de Maria S. Naná ficou viúva quando estava no $3^{\circ}$ mês de gravidez, seu esposo, que era ajudante de pedreiro, foi vítima de um acidente quando voltava de bicicleta do serviço. Ela se casou novamente e esse esposo assumiu a paternidade de sua filha, que tinha 10 anos. Separou desse marido e tinha um namorado. Bem humorada, queria mesmo era ser artista de teatro ou de televisão. Esboçou um roteiro para uma peça de teatro sobre os catadores. Foi uma conexão importante que tive com a comunidade, ia assumir uma bolsa para ela, mas a Incubadora conseguiu uma bolsa por meio de um projeto junto aos catadores.

Naná me ajudava nas tarefas de leitura e escrita, arrumava o lanche para servir na turma e, no final de semana, cuidava da manutenção da sala, durante a semana eu chegava mais cedo para limpar e organizar a sala. Ela chegava mais tarde, porque estava sempre trabalhando em diferentes lugares, no final, estava trabalhando junto com a mãe na reciclagem de sacolinhas, depois saiu e encerrou o ano trabalhando apenas na turma. Ela foi um elo muito importante para mim junto àquela comunidade, e, mesmo sem saber, me deu força em momentos muito importantes de minha chegada ali. A vida sempre foi difícil para Naná, tão jovem e com tanta história. Entre amor e raiva ela tecia os seus dias sempre em busca dos seus sonhos, envolta nas impermanências da vida. Eu aprendi a conviver com Naná, com sua acentuada impermanência na sua maneira de ser e estar. Era a maneira como ela conseguia 
estar conosco, que era a mesma como ela conseguia estar na vida. A sua presença sempre trouxe força para a turma.

A maneira como Naná se relacionou com a turma foi apenas uma dentre as maneiras como cada uma daquelas pessoas se permitiram estar ali. A participação de cada um naquela turma estava diretamente relacionada ao sentido da experiência de aprender a ler e escrever em suas vidas. Participar daquela turma era se permitir viver mais um desafio, em suas vidas já sobrecarregadas de tantos desafios, numa relação de confiança ao que estava sendo proposto e de descobrimento de outros mundos na descoberta da palavra escrita. Para 4 desses educandos colaboradores: Maria F, Maria M, Seu M e Seu F, essa foi a primeira vez que frequentaram uma escola. Seu F comentou sobre a experiência assim: "Me sinto feliz com isso. Agora eu, a professora, depois, só tem um mês pra ela aqui, que bom que ela viesse mais tempo, tivesse mais anos, mas num deu, né? É assim mesmo. Pode vim outra, então, né, no lugar".

\subsubsection{A cooperativa Acop e a comunidade}

A cooperativa Acop e a comunidade que vivia em seu entorno foram o nosso espaço de convivência onde a pesquisa se efetivou. Esse foi o lugar que proporcionou o ambiente e a teia de relações que deram o tom, o cheiro e o sabor da pesquisa. Localizava-se no Setor Albino Boaventura, na região Noroeste da cidade de Goiânia. Esse setor foi criado para abrigar cerca de 200 famílias que viviam em ocupações urbanas em áreas de risco e de proteção ambiental em três bairros da cidade, além das 22 famílias de catadores que viviam debaixo de um viaduto, sobre um trilho de trem desativado, na Rua 250, do Setor Leste Vila Nova, ao lado da Sociedade Goiana de Pecuária e Agricultura (SGPA). Esses últimos foram os catadores que criaram a Cooperativa Acop. Esses catadores foram instalados distribuídos em 4 quadras nesse Setor. As casas, pequenas, possuíam dois quartos, sala, cozinha e banheiro, cobertas de telha de barro, sem forro, eram rebocadas e pintadas; o chão, de cimento grosso. Tinham infraestrutura de água, esgoto, luz elétrica, telefone e asfalto. O Setor era também servido por uma linha de ônibus que se integrava às demais rotas da cidade. Com emoção, pois foi um trabalho resultante da parceria que fizemos nesta pesquisa, compartilho com Biano $^{23}$ (2014, p. 24) o que ela comenta sobre essa comunidade:

\footnotetext{
${ }^{23}$ BIANO, Janiere Rodrigues Rosa. Parceria feita com uma graduanda do curso de Licenciatura em Artes Visuais, para o suporte nas produções artísticas desenvolvidas na turma. Palavras de Marias e João:
} 
$\mathrm{O}$ que une os moradores da comunidade, trabalhadores da cooperativa e participantes das aulas é o chão. Foi a vontade de ter sua casa, a sua terra, que os juntou no objetivo de adquirir um pedacinho de chão, um lugar só deles, ao ponto de se aglomerarem num pequeno espaço, primeiramente na invasão de onde vieram, e depois quando finalmente transferidos, concretizaram seus sonhos.

[...] Os moradores da comunidade da pecuária permaneceram unidos até hoje como uma família, um sempre cuidando do outro.

Após aproximar-me mais da realidade da cooperativa Acop, percebi que ela reunia várias características que a tornavam adequada para o desenvolvimento da pesquisa. Dentre elas, especialmente uma que a distinguia das demais, essa cooperativa era situada junto a uma comunidade que morava em seu entorno e se sustentava basicamente desse trabalho. Por essa razão, a greve da coleta seletiva que estava acontecendo na cidade não afastava os catadores, pois ali era onde viviam. Além de morarem junto à cooperativa, as pessoas daquela comunidade possuíam uma história de superação compartilhada entre eles, pois viviam em uma favela debaixo de uma ponte na região noroeste da cidade. Outra característica importante é que essa comunidade já era catadora enquanto morava na favela e possuía uma longa trajetória, tendo família com mais de uma geração de catador. Então, os obstáculos foram sendo superados na medida em que essa comunidade foi se revelando como sendo a mais apropriada para a realização desta pesquisa e na medida em que crescia a aceitação à minha presença naquela comunidade. A força das águas que me envolveram, ao longo do percurso que naveguei, me lançou nessa comunidade que agregava as características necessárias para esta pesquisa.

O terreno onde a cooperativa está instalada foi doado e escriturado pela prefeitura para esse fim, portanto, a cooperativa não precisava pagar aluguel. O que ela arrecadava era para pagar as contas de água e luz e dividir entre os cooperados. Os catadores iniciaram seu trabalho naquela cooperativa ao relento, pegando sol e chuva. Não tinha cobertura, não tinha piso, não era cercado. Aos poucos e sempre com muita luta, conseguiram que uma empresa cobrisse o galpão e mais tarde que outra fizesse o piso. Conseguiram uma prensa, depois uma mesa de triagem. No início de 2014, receberam uma verba e fizeram a construção de uma estrutura de apoio: uma cozinha, um banheiro e mais uma sala para o escritório. O material

experimentações com materiais reutilizáveis no ensino de arte foi o Trabalho de Conclusão de Curso (TCC) dessa aluna, na Faculdade de Artes Visuais (FAV), da Universidade Federal de Goiás, Goiânia, no final do ano de 2014. Essa parceria está registrada em documento intitulado "Termo de Parceria em Projeto de Pesquisa", emitido pela Faculdade de Artes Visuais (FAV), da UFG. 
que chegava era depositado no chão. Ali mesmo iniciavam a triagem de alguns sacos, outros eram colocados sobre a mesa de triagem. Observei que a vida das cooperativas se mantinha em meio a épocas boas e outras de crise, uma irregularidade que se manifestava na remuneração dos catadores, eles mesmos nunca sabiam ao certo quanto receberiam em cada mês. F Catador explica essa realidade e, ao mesmo tempo, tece uma crítica e apresenta a sua sugestão:

(17) O ser humano, a classe média, ele não dá valor aos cooperados, porque se ele desse valor, as cooperativa era botado lá em riba. Como que nós tamo ajuntando, nós tamo ajuntando aquele material que aquelas pessoas joga fora, que tá gerando emprego e renda para a gente, ele se torna o pão de cada dia nosso. E o governo federal ou estadual, se quisesse ajudar, abrisse os olhos, ele podia pagar um salário para cada cooperado, fora os material que ele pega.

Essa situação vivida por esses catadores é um desdobramento da falta de conexão entre a atividade que desenvolvem, o material que chega na cooperativa e a participação da sociedade na coleta seletiva. Falta de ações do poder público no cuidado com o lixo e com a coleta seletiva, uma realidade complexa e que pede urgência em seu tratamento. Aos catadores resta uma condição degradante, em decorrência da falta de envolvimento da sociedade com ações educativas de preservação do meio ambiente. A todos nós resta aprendermos que a nossa existência somente se mantém em conexão com ações solidárias, em conexão com a rede de sustentabilidade da vida no Planeta Terra.

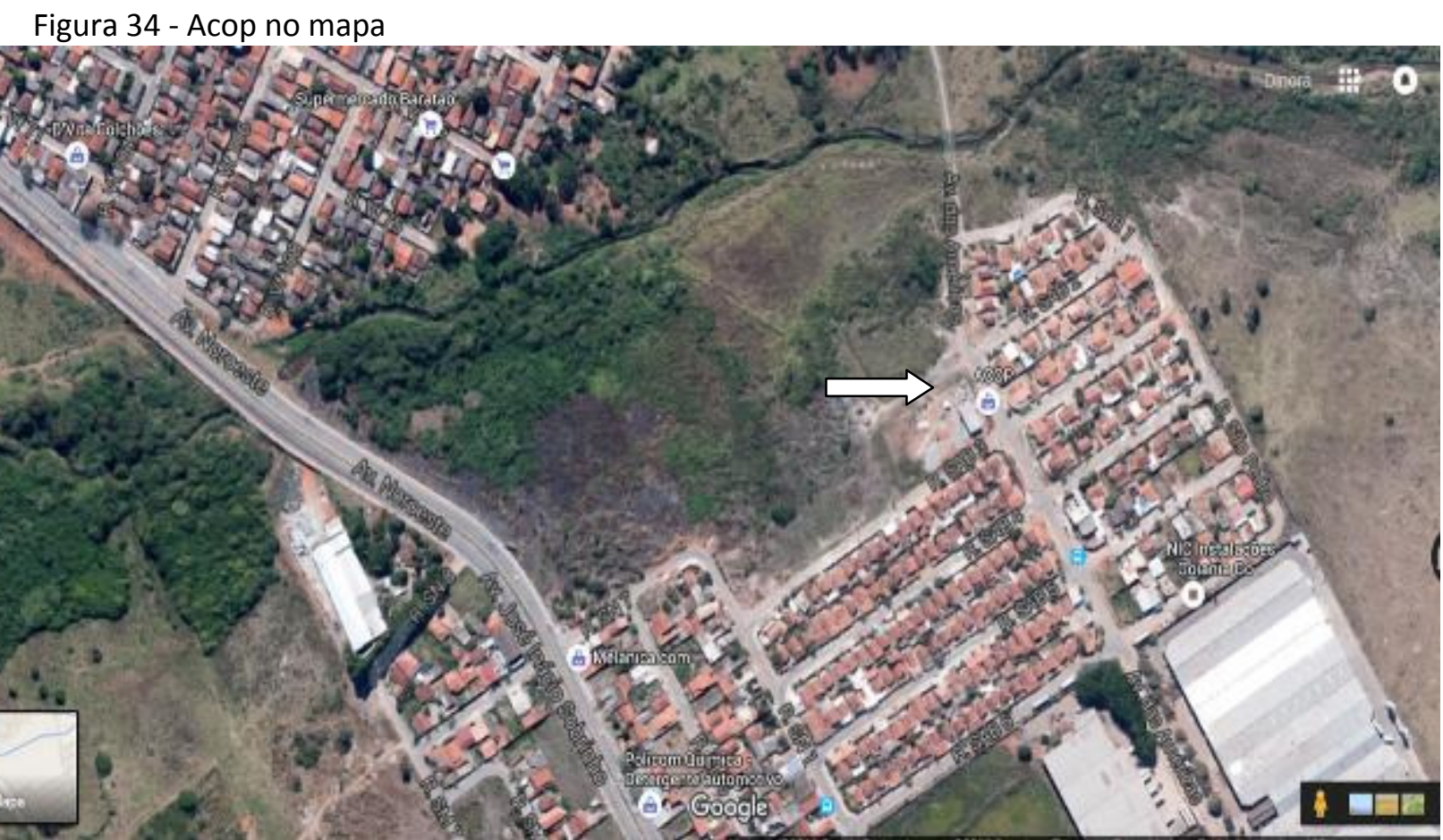

Fonte: Google Maps. Acessado em abril de 2016. 


\subsubsection{O lugar do encontro}

A pesquisa que realizei, inserida em uma realidade que implora mudanças capazes de proporcionar a (re)construção do mundo e salvaguardar a vida no Planeta, demandou um campo constituído para a sua materialização. Ou seja, embora existindo uma demanda de alfabetização no contexto social gerado pela coleta seletiva, não havia um lugar organizado e pronto para a realização da experiência. A estruturação da turma suscitou muitos enfrentamentos e vivi dificuldades expressivas que precisaram ser contornadas a fim de que a experiência se efetivasse. A existência tem corpo, a vida se manifesta a partir de um lugar. $\mathrm{O}$ lugar da existência, o lugar de viver, o lugar da escola, se encontrando no desencontro consigo, com o outro, com a humanidade, com a vida. Todos ameaçados. Foi nesse não lugar que segui o caminho da persistência e superação para conseguir formar uma turma junto à comunidade da cooperativa Acop, percorrendo o último veio de água que ainda brotava daquele chão, para a formação da turma.

\subsubsection{Encontros no galpão}

Com a turma instalada somente na Acop, passei a viver aí as novas situações de cada dia. Com o início das atividades, a novidade repercutiu e outros educandos da comunidade me procuraram para se cadastrarem na turma. Fiquei com 12 alunos cadastrados nessa turma, que eram dessa comunidade, mas mantive o cadastro dos outros da Coocamare para garantir o número de alunos da turma exigidos pelo AJA-Expansão. Também nesse grupo a frequência era muito irregular, alguns desses que se cadastraram nunca compareceram, mesmo assim, a experiência se deu com 5 que frequentaram mais assiduamente, enquanto 4 alunos tiveram a frequência irregular, e finalizou com efetiva participação de 7 educandos. Uma dificuldade encontrada nessa cooperativa foi a falta de um lugar adequado onde a turma pudesse ser instalada. Como não podia mais adiar o início das atividades, iniciei as aulas no mesmo galpão onde os caminhões descarregavam a coleta da cidade, numa semana em que a coleta estava em greve. Com a redução do material foi possível compartilhar esse espaço entre os resíduos e a turma.

Por ser constituída somente por cooperados, adultos e em alfabetização, essa turma proporcionou um ambiente específico e próprio para o encontro da Educação Ambiental com a Educação Popular. E as peculiaridades desse encontro, que se deu nesse local, asseguraram a originalidade e o valor deste estudo. De acordo com o estabelecido pelo AJA-Expansão, as aulas deveriam ter a duração de $2 \mathrm{~h} 30 \mathrm{~min}$, podendo o grupo definir o melhor horário. Devido à 
proximidade das aulas ao local do trabalho, ficou combinado que as aulas fossem iniciadas às $17 \mathrm{~h} 30 \mathrm{~min}$ e indo até às $20 \mathrm{~h}$, com aulas de $2^{\mathrm{a}}$ a $5^{\mathrm{a}}$ feira, pois na $6^{\mathrm{a}}$ feira é feita a formação continuada dos educadores populares da cidade, em espaço da SME de Goiânia. Devido à greve da coleta seletiva, os alunos sugeriram que as aulas poderiam iniciar as $15 \mathrm{~h}$, para finalizar as $17 \mathrm{~h} 30 \mathrm{~min}$. Isso favoreceu a utilização do pátio na luz do dia.

A aula no galpão foi uma experiência interessante. Iniciou no dia 26 de maio de 2014, com 7 alunos frequentando, mas que se alternavam na frequência. Um dia tinha 5, em outro tinha 4 educandos e nem sempre os mesmos. Em função da greve, o grupo decidiu iniciar as atividades às $15 \mathrm{~h}$, indo até às $17 \mathrm{~h} 30 \mathrm{~min}$. O AJA-Expansão já havia fornecido uma parte do material didático para o início das atividades e nesse primeiro dia de aula já entreguei, para cada aluno, caderno, lápis, borracha, régua, apontador e lápis de cor. O pátio era uma área coberta, com pé direito bem alto, em estrutura de metalon, de aproximadamente $20 \mathrm{~m} \mathrm{X} \mathrm{08m.}$ Tinha o piso cimentado e era aberto. Ficava localizado em frente ao portão de entrada da cooperativa, a uns $5 \mathrm{~m}$ de distância. A cooperativa possuía uma área de 3 mil metrosquadrados, toda cercada por um alambrado recoberto por um arbusto que fazia uma cerca viva. Por ser aberta, o momento da aula chamava atenção das pessoas que passavam. Com isso, algumas mulheres da comunidade e alguns rapazes, bem jovens, passaram a acompanhar as atividades. Iam se acomodando e ficando por ali. Todos os dias a turma era organizada, o alfabeto foi colocado em um barbante para facilitar a ser pendurado e retirado em cada encontro. O lugar para sentar e a mesa de apoio eram improvisados com caixas e latas, cobertas com papelão. Sinceramente, eu gostava daquele cenário. Parecia mesmo algo bem teatral, onde a ficção e o real se aliavam rompendo a dureza daquela realidade na fantasia transformada em sonhos. Ali iniciamos a leitura das palavras, pela leitura do próprio nome.

Após viver a experiência de fechamento da turma com o grupo da Coocamare, meu maior cuidado era para que essa turma se fortalecesse e que aquela experiência não se repetisse. Via a metáfora da água se materializando no comportamento dos catadores, uma oscilação de fluxos que se movimentavam em diferentes direções. Eu tentando segurar uma turma de catadores alfabetizandos, para aprenderem a ler e escrever em uma formação humana com estratégias de EA, enquanto eles escorriam feito água diluídos no fluxo da sobrevivência. A experiência vivida me fez perceber que os alfabetizandos hesitavam entre a resistência em frequentar a escola e a satisfação por estarem na sala de aula aprendendo a ler e escrever. Ficamos no pátio da cooperativa até o dia11/06/2014, a greve estava terminando, a coleta se normalizando, o pátio enchendo de material e o nosso espaço se finalizando. Aquele era mesmo um lugar muito provisório, porque além de estarmos compartilhando o espaço 
com os resíduos, quando terminasse a greve o horário teria que ser no noturno e iríamos ter problemas com a falta de iluminação adequada e problema também quando começasse o período das chuvas. Conversamos sobre a dificuldade que estávamos encontrando pela falta de espaço físico, compartilhando a situação com o grupo.

Figura 35 - Encontro no galpão

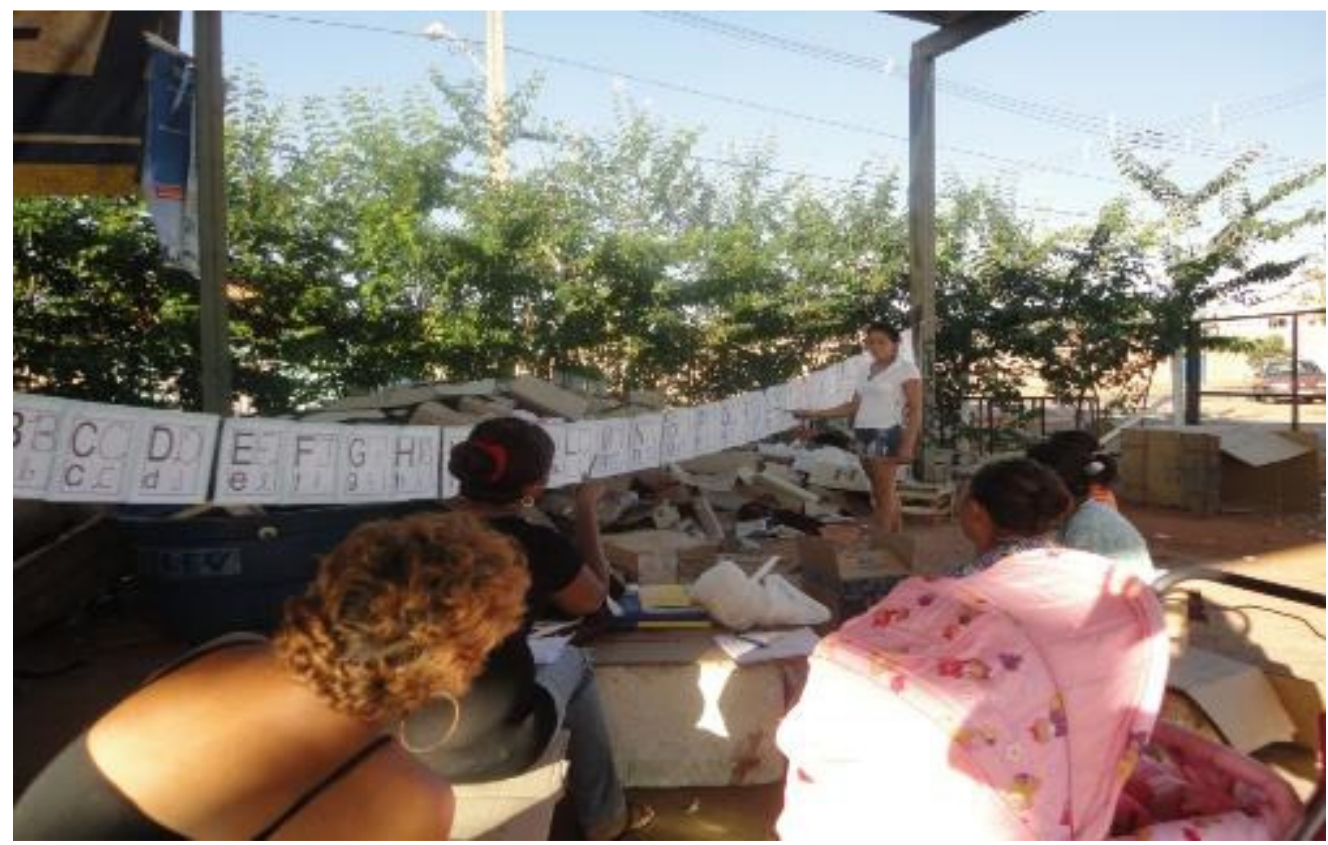

Fonte: Acervo da pesquisa. Galpão da Acop. Maio de 2014.

\subsubsection{Encontros na varanda}

Uma catadora, aluna da turma, ofereceu a varanda de entrada da casa dela para continuarmos as atividades, pois o grupo decidiu que não queria que a atividade se interrompesse. No outro dia, após conversar com o marido, ela confirmou que podíamos levar a turma para sua casa. Então, combinei com ela uma locação. Essa área era coberta, tinha a frente toda fechada com a parte externa rebocada e pintada na cor azul. Na parte interna recebia ventilação e iluminação natural somente pelas partes laterais fechadas de grade que davam para o fundo da casa. O chão era um contra-piso de cimento grosso, as paredes chapiscadas, sem reboco e sem pintura, e havia material recolhido dos resíduos da cooperativa recostados em todas as paredes do espaço. No dia 12/06/2014, com muita gratidão, o atendimento foi iniciado nesse lugar. As instalações aí ficaram melhores que as do galpão da cooperativa, a educanda forneceu umas mesinhas de plástico, com cadeiras. Colocamos o alfabeto, dividido em duas fieiras, pendurado em uma cabeceira da varanda, o nosso material 
ficava guardado em duas caixas de papelão colocadas sobre um gabinete vazio de uma máquina de costura e sobre outro móvel, recostados na parede. Tinha apenas uma lâmpada e precisávamos ficar concentrados sob esse ponto de iluminação para fazer as atividades. Todos os dias, ao final da aula, tudo tinha que ficar guardado, o alfabeto era suspenso e preso no alto, porque a catadora tinha dois cachorros grandes e bravos que ficavam soltos à noite naquele lugar. Enfim, ali era a casa da Maria W que nós estávamos ocupando. Solicitamos ao AJA-Expansão, por meio das coordenadoras, um quadro-de-giz e carteiras, mas esse material nunca foi entregue, talvez eu devesse ter encaminhado por ofício.

A mudança para a casa dessa catadora gerou a desistência de um aluno que estava assíduo nas aulas. Fui à sua casa, conversei com ele, a esposa estava junto, não disse nada, ficou calada todo o tempo. Ele falou que era melhor a aula na cooperativa, que na casa das pessoas não era bom, por isso que ele não foi mais. Mas um dia ele esteve na turma, assistiu aula todo satisfeito, com boa participação. Fiquei com a impressão de que havia algum elemento a mais direcionando as decisões daquele educando, que eu não estava conseguindo decifrar. Depreendi dessa situação que precisava de um lugar mais institucional para trabalhar com a turma. Isso, inclusive, era um critério colocado nas diretrizes do AJA-Expansão. Todas essas situações me diziam que aquele ainda não era um bom lugar para instalar a turma, mas a catadora estava satisfeita por nos receber em sua casa e isso me deixava mais tranquila ao mesmo tempo em que exigia mais cuidado para fazer qualquer mudança. Comecei a pensar em outro lugar, mas qual lugar? E como fazer a mudança sem perder a aluna e sem causar qualquer descontentamento?

Nessa mesma noite que iniciamos as atividades na varanda da casa da catadora o seu esposo, dono da casa onde estávamos, decidiu se inscrever como aluno da turma também. Como não tínhamos encontro na $6^{\mathrm{a}}$ feira, eu costumava ligar para Naná, no início de cada semana, para ter notícia da comunidade, saber como estavam as coisas e me organizar para a nova semana. Na $2^{\text {a }}$ feira, dia 16/06/14, quando liguei, ela me informou que o catador, dono da casa cuja varanda estávamos ocupando, se envolveu em um acidente de carro, após ter bebido, com mais dois companheiros, em um bar das proximidades, e se encontrava internado em um hospital. Após o impacto da notícia, eu quis saber como ficaria o nosso espaço com essa situação, mas Naná me informou que Maria W estava querendo que as aulas continuassem em sua casa, que ela estava precisando de nossa companhia nesse momento difícil em que o esposo estava hospitalizado.

À noite, nos reunimos na casa da catadora para continuarmos nossas atividades. Maria W nos contou que isso não era o hábito dele. Que ele não era de beber. Pensei: teria alguma 
relação com o fato de ele ter se inscrito na turma? Nessa noite, desenvolvemos nossas atividades com 4 alunas na turma, a dona da casa, Maria $\mathrm{W}$, disse que não estava com cabeça pra fazer as atividades, mas acabou se integrando ao que estava sendo proposto. Compartilhamos o ocorrido e trouxemos essa situação para as nossas histórias de vida. Estávamos trabalhando com o nome próprio de cada um, refletindo também a partir de um poema que falava sobre o nome que damos a todos e a tudo, num movimento multidimensional, sistêmico, do micro ao macro.

Após a aula, enquanto guardávamos o material, Naná me contou sobre alguns fatos que estavam acontecendo. Contou-me que já não era mais a presidente da cooperativa, que finalizou o seu mandato, saiu da cooperativa e estava trabalhando de carteira assinada em uma grande empresa de temperos da cidade, que com a crise da coleta seletiva estava difícil ficar na cooperativa. Com relação à turma, disse que tinha uma carona para voltar do serviço e que 17h40min já estaria na turma. Naná era uma conexão direta de nossa turma com a cooperativa e com a comunidade, ela estava sempre ali participando, decidindo junto com o grupo, atuando. Essas informações movimentaram minhas águas, mas me fizeram ver o encontro da fragilidade de nossas vidas.

Na noite seguinte realizamos a aula sem a Naná. Às 19h20min, quando já estávamos quase finalizando as atividades, ela chegou. Disse que não tinha mais a carona na saída do trabalho e que, vindo de ônibus, era aquele o horário que conseguia chegar. Ela própria admitiu que desse modo não dava pra continuar como educadora popular na turma. Nova desordem surgindo da tensão entre a ordem e a desordem, se rearticulando nas possibilidades da recursividade. Continuamos, sem Naná, as atividades na turma. Na semana seguinte, discutíamos sobre a cooperativa e a reciclagem a partir dos jornais da cidade que falavam sobre a greve da coleta seletiva. Quase no final da aula, Naná aparece pedindo para continuar na função, contando que não se adaptou ao novo emprego. Ficamos contentes com o seu retorno, a turma estava sentindo sua falta, precisávamos de sua presença conosco, mas conversei com ela lembrando que seu vínculo era feito por meio da Incubadora Social da UFG e que não ficava bem a cada semana eu comunicar uma decisão diferente, além do mais, se perdêssemos essa bolsa não teríamos como conseguir outra. Assim, entre avanços e recuos, envolvida no movimento dessas águas, aprendi a permear os fluxos e prosseguir o percurso, contornando as pedras, ouvindo o ruído das águas que seguiam seu incontível fluxo, para se lançarem em cascata em direção ao vale.

A semana de 23 a 26/06/14 foi de decisões importantes para a continuidade de nossas atividades. Desde $2^{\mathrm{a}}$ feira, quando visitava a cooperativa para conversar com os cooperados 
cadastrados para que participassem da turma, fiquei pensando no que Seu M me falou. Ele apontou para o final da rua, me mostrando uma sala que tinha lá, e disse que aquela sala já tinha sido usada para uma turma de alfabetização e que se a turma fosse pra lá ele frequentaria. Essa noite voltei pra casa pensando muito sobre essa questão. Naná já tinha me falado sobre essa sala, me falou que a cooperativa a alugava para guardar as latinhas, um computador e objetos de valor da cooperativa e que ali uma professora iniciou as atividades de uma turma de alfabetização.

Dia 25/06/14, $4^{\mathrm{a}}$ feira, cheguei mais cedo na casa de Maria W para as atividades daquela noite. Enquanto aguardava a chegada das alunas, ela me convidou para sentar no sofá da sala. Contou que o seu esposo seguia hospitalizado e sobre como ela estava se sentindo. Aproveitei e falei que estava pensando em alugar aquela sala e se ela se importaria com isso. Ela concordou, disse que não tinha nenhum problema e que fosse feito o melhor pra turma. Fiquei contente com essa conversa. Maria $\mathrm{F}$ chegou para a aula e fomos juntas conversar com a dona da sala. Como ela não estava em casa, conversamos com o seu filho e agendamos o nosso retorno para a tarde do dia seguinte. Maria $\mathrm{F}$ me chamou para que fôssemos até à casa de uma amiga, na rua ao lado, para convidá-la para a turma. Fomos à casa da Maria $\mathrm{P}$, que tornou-se uma aluna assídua da turma. Ela ainda acompanhou, por dois dias, as atividades na área da casa de Maria W. Ânimo novo, água nova brotando.

Figura 36 - Encontro na varanda

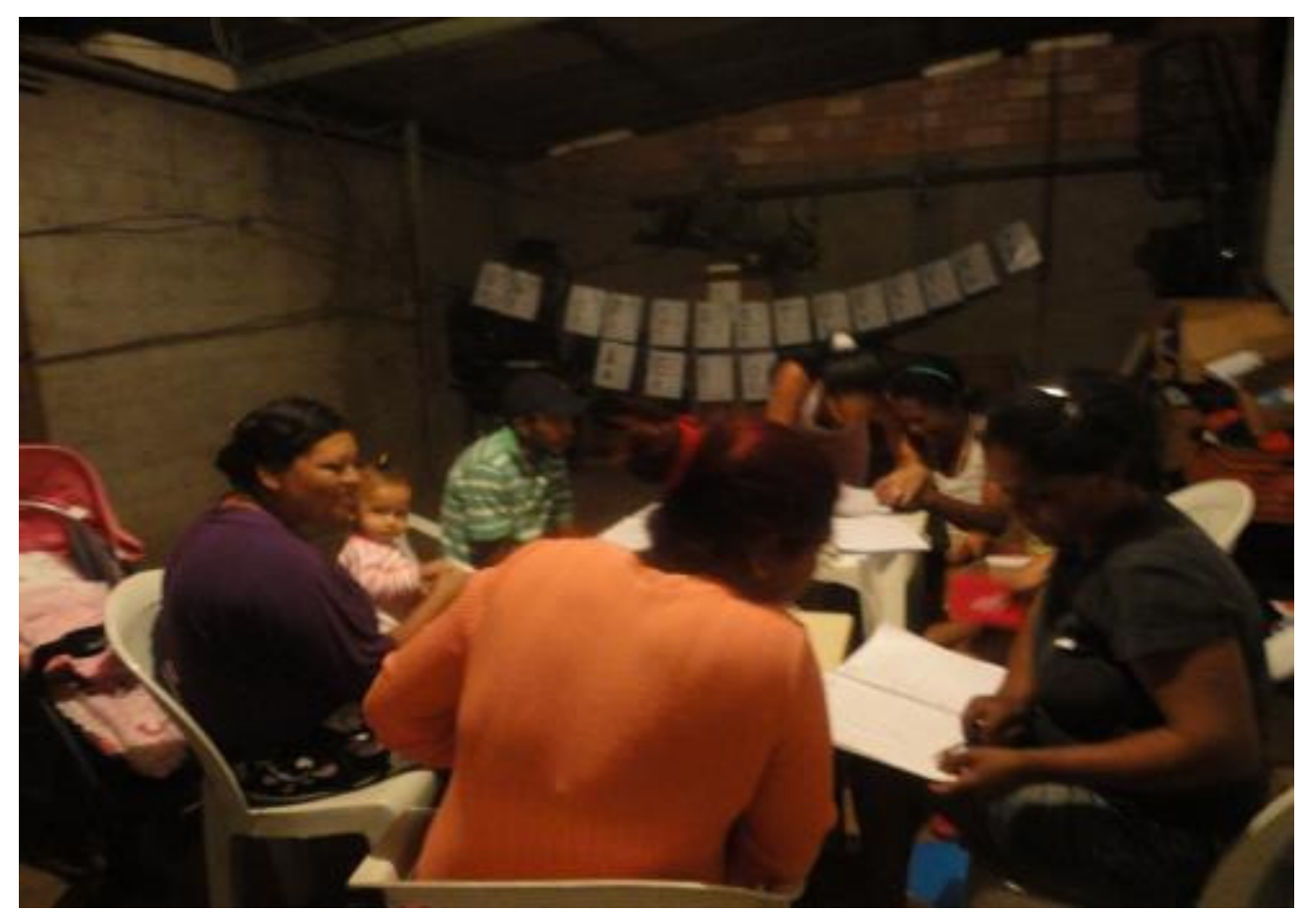

Fonte: Acervo da pesquisa. Maio de 2014. 


\subsubsection{Encontros na sala}

No dia 26/06/14, $5^{\text {a }}$ feira, eu e Maria $F$ nos encontramos com a proprietária da sala. Ela não estava com as chaves para abrir a porta, mas andamos pelo lado de fora e ela explicou como era a sala por dentro. Contou também que havia uma telha quebrada, mas que ela logo faria a troca dessa telha. Combinamos o valor de $\mathrm{R} \$ 350,00$ por mês e que seria até o mês de dezembro. A bolsa que eu recebi como educadora popular foi de $\mathrm{R} \$ 400,00$, o suficiente para pagar esse aluguel. Disse que me entregaria as chaves na $2^{\mathrm{a}}$ feira. Elaborei um recibo para ser assinado mês a mês, junto com o pagamento, que detalhava sobre o tipo do imóvel que estava sendo alugado e para que finalidade, mencionando o AJA-Expansão e os catadores da Acop. Tanto a proprietária quanto eu ficamos contentes, ela, por ter conseguido alugar o seu imóvel que estava fechado desde quando a cooperativa o alugou, eu, por ter conseguido um lugar mais adequado para realizar o trabalho e fortalecer a presença da turma na comunidade.

A sala era situada no final da mesma rua onde ficava a cooperativa. Essa sala havia sido construída para a instalação de um açougue, mas foi o templo que nos aguardava para acolher-nos. Fechei o contrato e no dia $1^{\circ}$ de julho nos instalamos ali. O tamanho era de $6 \mathrm{~m}$ por 4m. Possuía uma bancada de inox com uma pia em uma parede recoberta de azulejo branco. As paredes eram rebocadas e pintadas, o piso em cerâmica de cor clara. A ventilação e a iluminação natural não eram boas porque não tinha janela, elas se davam por uma porta de $80 \mathrm{~cm}$ que tinha ao fundo, pela porta de aço da frente, que abria se enrolando para cima, como uma persiana, e pelo uso de um ventilador. Não possuía banheiro, Maria F, que morava bem em frente, ofereceu o banheiro da casa dela, se alguém precisasse, mas a sala possuía tudo o que precisávamos: um espaço adequado, estrategicamente bem localizado, que contribuiria para um trabalho significativo e capaz de responder às questões que nos arremessavam nesses caminhos. Naquele contexto, esse era o espaço que havia de melhor para a realização da pesquisa. Não era possível questioná-lo, a despeito de ser ou não o lugar ideal para a alfabetização de catadores com estratégias de EA. Mesmo porque, o lugar ideal, a partir das concepções e perspectivas adotadas, seria mesmo o lugar possível, o lugar do lugar.

Consegui uma pessoa da comunidade, um rapaz irmão da Naná e filho de Maria S, aluna da turma, que executou todo o trabalho da pintura da sala. Pintou por dentro e por fora em azul anil. Como o AJA-Expansão não forneceu, um quadro de giz foi pintado em uma parede, com tinta especial, um quadro verde para escrita e, na parede em frente a essa, um quadro branco para tela de data-show. Além das paredes internas, com todos os detalhes dos quadros, fez a pintura externa com a arte da logomarca. Para ele, esse trabalho foi muito 
importante, gostou da experiência, ele nunca havia feito uma pintura com tantos detalhes e ainda com a arte da logomarca da pesquisa. Ele se tornou um parceiro que sempre estava por perto, demonstrando carinho, amizade e proteção. Maria W emprestou 3 mesinhas de plástico, duas quadradas e uma redonda, e 5 cadeiras, a mesma catadora que cedeu a varanda de sua casa. Eu levei mais uma mesa de plástico de 6 lugares e 6 banquinhos. Na fachada externa, pintada com a mesma cor, foi colocada a logomarca da pesquisa. Nossa sala ficou linda, todos gostaram.

A logomarca da pesquisa nasceu de outra ideia que surgiu na turma. Como as crianças, filhas dos catadores que estudavam na escola próxima, estavam tendo problemas de rendimento escolar e de falta de 'boas condutas', tivemos a sugestão de fazermos contato com a escola para uma tarde de exposição e palestras dos catadores, para falar sobre a cooperativa, a reciclagem, o meio ambiente, a educação ambiental. Para isso, sugeriram uma camiseta especial para o evento, com uma logomarca própria. Não foi possível realizar o evento, faltou agendamento para essa atividade, mas a logomarca foi criada, aprovada pelo grupo e a camiseta ficou pronta. Essa se tornou uma logomarca da pesquisa. Ao apreciarem a logomarca Maria F falou: "Professora, isso é Lindo! Lindo! Lindo!" Seu J comentou sobre a espiral: “Aí eu vejo todos os princípios. Tudo vai crescendo, o corpo e as ideias também."

Figura 37 - A logomarca

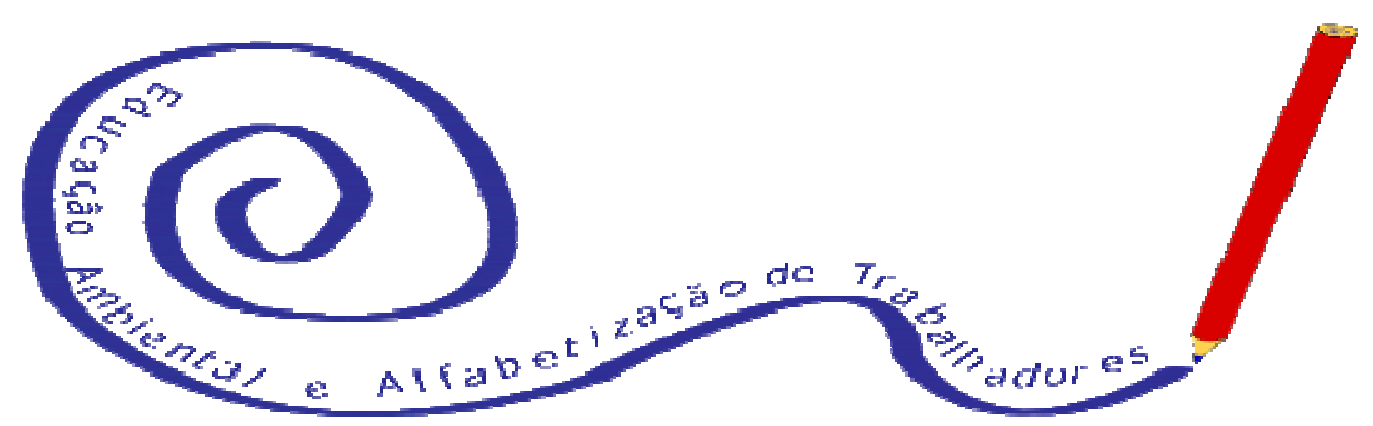

Fonte: arquivo da pesquisa. Produção Gomes, Dinorá de Castro e Virgílio de Castro Neves.

A cooperação do grupo em toda aquela movimentação fortalecia as ações. Dizia-me que eu estava sendo aceita e acolhida pela comunidade, que havia ali o interesse em que a turma permanecesse, o interesse em aprender a ler e escrever em um espaço integrado com a vida vivida ali. Interessante mencionar que a telha quebrada abria uma grande fenda no telhado, que era feito de telhas grandes, de Eternit, se chovesse molharia toda a sala. A chuva ameaçava cair e nós esperando que a senhorio fizesse o conserto. Passados dois meses, o telhado foi arrumado. Por força da natureza, nessa mesma noite a chuva caiu bem forte. Todos 
perceberam a 'coincidência' e comentaram o fato, celebramos com alegria. Era a celebração das águas. Abrigados e envolvidos em tanta água.

Figura 38 - Encontro na sala

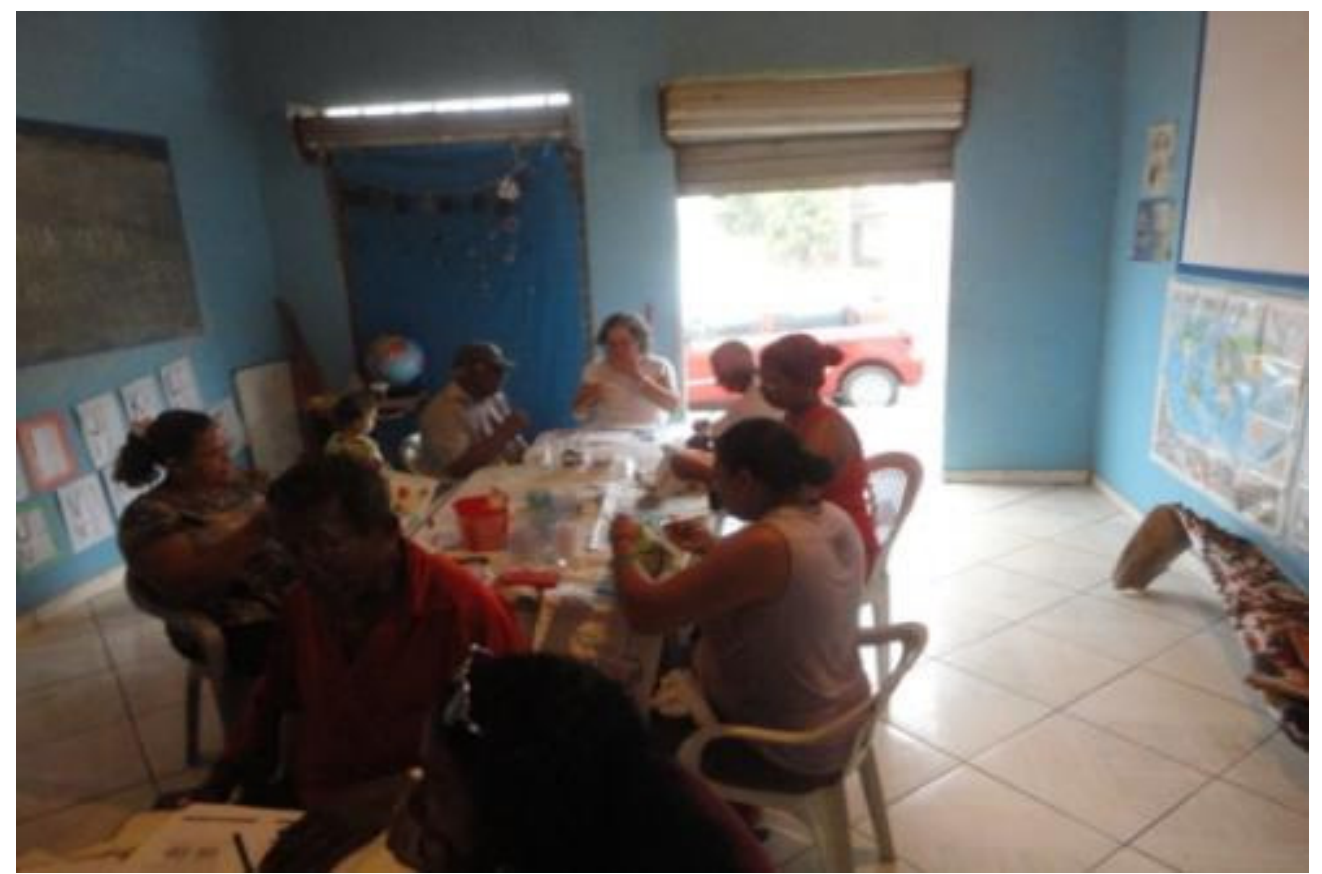

Fonte: Acervo da pesquisa. Julho de 2014.

Nesse espaço a criatividade fluiu, os vínculos se estreitaram, a confiança se estabeleceu. Aos poucos, nosso trabalho foi se fortalecendo, na medida em que fomos desenvolvendo as atividades, promovendo a leitura e a escrita, inventando estratégias, sensibilizando. Também a turma se definindo e a ordem se estabelecendo. Na maioria das vezes tinham 5 educandos, algumas noites apareciam 8.

Muitos obstáculos precisaram ser administrados ao longo desse caminho relacionados, principalmente, com a natureza problematizadora que envolveu os principais atores da pesquisa, ou seja, situações que se definiram na mesma proporção em que esses atores decidiam se envolver com o seu processo de letramento. Sei que as resistências existem, que são de naturezas diversas e que dificultam a decisão, por isso precisei intervir nesse espaço sabendo que esses sujeitos têm o direito de permanecer na condição de não letrados, mas tentando ajudá-los a remover as pedras que foram lançadas sobre eles, "quebrando pedras e plantando flores". (CORA CORALINA, 2004, p. 213). Por mais que os estímulos externos sejam feitos e as condições estejam assentadas, sei também que esse é um ambiente que se inicia na subjetividade dos sujeitos envolvidos: suas histórias, seus sentimentos, suas leituras de mundo, para se materializar em um espaço físico onde os encontros se efetivem, as trocas aconteçam e os fenômenos possam emergir da tessitura das existências. 
Os espaços de encontro fornecem um conjunto de informações provenientes da realidade vivida, pois esses espaços possuem uma expressão multidimensional e carregada de significados para aqueles educandos colabores. O espaço da comunidade no Setor Albino Boaventura, o espaço da cooperativa Acop, o espaço para a instalação da turma estão interconectados e possuem um sentido próprio para aquela comunidade. Seu Iramar lembra do movimento se iniciando ainda na favela: "Com esse conhecimento do movimento foi aonde despertou a ideia de organizar a comunidade onde nós morávamos, uma favela que ficava na Vila Nova, bem ao lado da Pecuária."

Esse grupo de catadores compartilhou uma história difícil de muita luta e superação, porque a situação como eles viviam na favela era de absoluta falta de condição de vida. Por isso, eles sabiam o valor do lugar onde estavam morando e da cooperativa, sabiam também que tinham ainda muita luta pela frente pelo reconhecimento da categoria profissional dos catadores, pelas boas condições de trabalho e por uma vida digna. E o espaço para eles era algo da esfera do sagrado, na perspectiva de que "O sagrado é o que liga." (NICOLESCU, 2000 , p. 147). Sob esse ponto de vista, todos ali estavam profundamente interligados e intensamente interconectados sob todos os pontos que podem se manifestar das vidas compartilhadas ali.

O espaço para a instalação da turma da experiência de alfabetização também foi conquistado com muita dificuldade e não podia ser diferente, mediante a tudo o que representa o espaço para aquelas pessoas, do espaço físico ao existencial. Dessa maneira, da experiência vivida para a instalação da turma, cada espaço teve um sentido diferente. $\mathrm{O}$ espaço da cooperativa Acop, embora com toda a falta de condição para as nossas atividades, foi um ambiente agregador. Era aberto e convidativo a quem passava, tornava público o que estávamos fazendo ali e includente de todos que chegavam. Essa experiência evidenciou a necessidade de um prédio nessa cooperativa para o atendimento a muitas demandas, dentre elas as demandas do universo didático pedagógico da educação. Um prédio para abrigar a administração, as reuniões, as produções artísticas e artesanais. Abrigar também um círculo de cultura, as manifestações culturais, as crianças, os jovens, os adultos e os idosos. Esse é um sonho que já existe e, em visita à nossa turma, Seu Iramar contou a respeito desse projeto, explicando que já tem buscado o financiamento para ele em vários lugares.

O que se percebe é que a maior dificuldade para a realização desse projeto está associada à desvalorização da categoria do catador. Na mesma proporção em que a categoria não é vista, não é reconhecida socialmente, também não são vistas as suas necessidades e reivindicações. Assim, as lutas estão todas interconectadas: a do lugar, a do catador, a da 
coleta seletiva, a da escola para essas pessoas. Porque, também em decorrência do que vivemos para a instalação da turma, ficou evidente que as condições devem ser adequadas para o desenvolvimento de um ensino de qualidade. Ficou evidente, também, que não basta ter política pública para alfabetização de adultos, se as diretrizes não se aproximam da realidade dos catadores e, provavelmente, da realidade de muitos grupos de adultos alfabetizandos que existem em nosso país.

\subsubsection{Os encontros nas aulas}

O meu maior desafio deste estudo foi fazer com que os princípios e as concepções que orientavam a pesquisa se manifestassem em nossos encontros de partilha. Esse era o momento mais importante de toda a proposição, as atividades em cada encontro tinham que possuir um encadeamento coerente entre o proposto e o realizado. As estratégias da EA precisavam ser conexões para fazer fluir as trocas, em encontros que se manifestassem em várias dimensões: o encontro consigo, o encontro com o outro e o encontro com o mundo. Esse foi um momento da experiência vivida onde todos éramos aprendentes, enquanto os educandos aprendiam a ler e escrever, eu aprendia a alfabetizar, pois nunca havia trabalhado como alfabetizadora e, mais ainda, como alfabetizadora popular de catadores.

Eu planejava os encontros da turma em um roteiro ${ }^{24}$ sugerido pelas coordenadoras do AJA-Expansão. Para cada encontro, um planejamento. Esses planejamentos nunca se cumpriram da forma como estavam delineados, a realidade complexa e abrangente, sempre carregada de imprevisibilidades, nos envolvia em teias tecidas com os fios do contexto daquele lugar que brotava a cada dia. Às vezes organizava um roteiro para a semana, dando encadeamento semanal às atividades. Todo educador precisa planejar suas atividades, até mesmo o educador transdisciplinar, o planejamento é uma organização necessária, mas interagindo com a desordem. Morin (2008, p. 72) nos diz que "Assim, para que haja organização,é preciso interações: para que haja interações é preciso encontros, para que haja encontro é preciso desordem (agitação, turbulência). As partes desse roteiro eram: 1) Data, 2)Tema, 3)Objetivo, 4)Momento inicial, 5)Momento central, 6)Momento final. As situações de cada dia eram as forças determinantes do que se sucederia.

A roda de sensibilização era colocada no momento inicial das atividades, mas nem sempre era possível ser no início, porque o grupo chegava aos poucos, ficávamos aguardando

\footnotetext{
${ }^{24}$ Esse roteiro está incorporado aos apêndices.
} 
a definição do grupo de cada aula para iniciar a roda, mas quando ele se definia, muitas vezes outras atividades já estavam sendo desenvolvidas. Então, a roda ficava para o final, ou nem acontecia. Nessas rodas fazíamos a respiração profunda, acompanhada de uma condução, para que a sensibilização acontecesse em interação com os reinos que sustentam a vida. Junto, fazíamos um trabalho de corpo, seguindo uma técnica oriental, o Chi Kung, que tem a finalidade de estimular e promover uma melhor circulação do sangue no corpo, energia Chi (energia vital), segundo a sabedoria chinesa. Os educandos apreciavam essa técnica, diziam que o corpo ficava melhor para o trabalho na cooperativa. O trabalho com o corpo é um caminho para o pertencimento, segundo Catalão (2011, p. 77)

Essa unidade entre o corpo e psiquê manifesta-se nas memórias guardadas pelo corpo das experiências vividas e aprendidas - manifestando assim a unidade indissociável entre as dimensões biológica e psicológica do ser humano. Nosso corpo cognoscente guarda as marcas das diversas fases da nossa história biológica, não como resquícios do passado, mas como parte da estrutura dos processos cognitivos atuais.

Figura 39 - Sensibilização

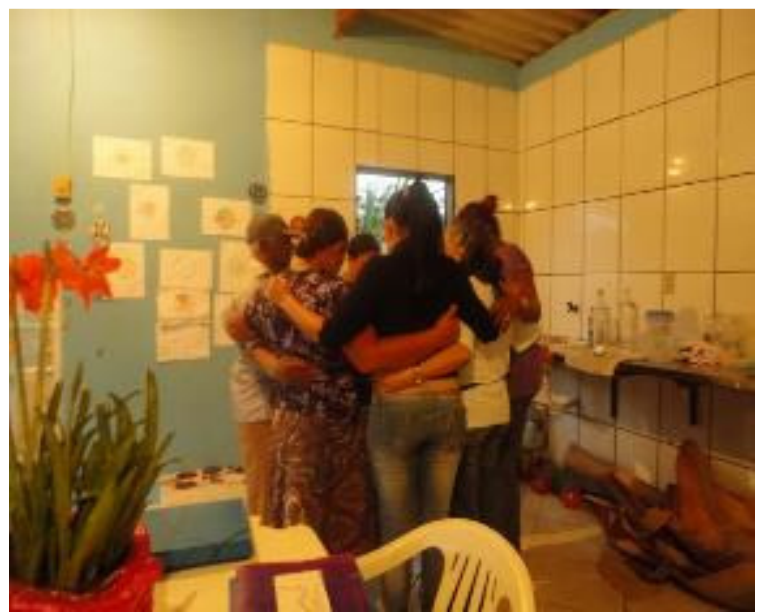

Figura 40 - Chi Kung

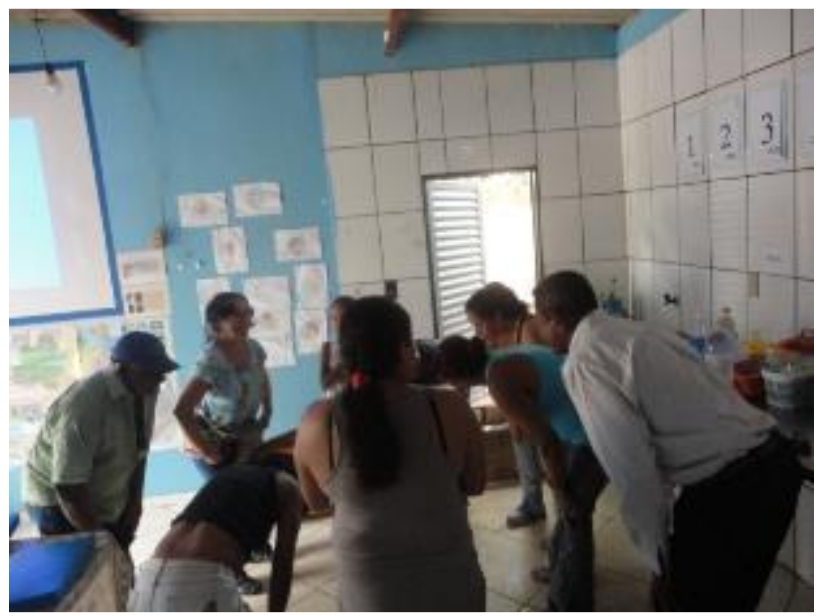

Fonte: Acervo da pesquisa. Outubro de 2014.

A localização da sala de aula era em um ponto estratégico de onde se avistava toda a rua onde se localizava a cooperativa. Aquela era uma rua bem movimentada na comunidade. No início, avistávamos carros de luxo que entravam e paravam sempre no mesmo lugar, depois fiquei sabendo que ali era um ponto de venda de drogas e, da sala, eu fotografava tudo. Depois esses carros sumiram, presumo que devem ter sido avisados que estavam sendo observados e mudaram o horário de atendimento. Em outro dia avistamos carros da Rotam que prenderam um filho de uma catadora, ela ainda assistiu algumas aulas em nossa turma, no galpão e na varanda. O ocorrido foi até notícia da televisão. A turma ficou sensibilizada com 
aquilo e Maria F sugeriu que fizéssemos vibrações pela harmonia, serenidade e paz naquela família, em nossa roda de sensibilização. Assim, íamos construindo nossas aulas a partir das forças que se manifestavam em cada dia. O número de educandos e a hora que cada um chegava à sala era outra situação relevante determinante dos procedimentos dos encontros.

Os cuidados com o acolhimento de cada educando eram constantes. Se ele não comparecia um dia, no outro era recebido com amparo e compreensão de seus motivos para não ter ido. A intenção era fazer com que se sentissem tranquilos e pudessem estudar a partir de suas motivações internas. Então, a forma de alimentar essas motivações era mantendo um ambiente sem cobranças, um ambiente apenas de trocas de ensinamentos e aprendizagens com o grupo que estivesse presente, com alegria, descontração, amorosidade, acolhimento, escuta sensível e respeito ao tempo de cada educando.

Os educandos iam me indicando a maneira como trabalhar, fui percebendo que cada um tinha um conhecimento diferente do outro e um jeito próprio de aprender. Para dar conta das peculiaridades, o método era eclético, todas as maneiras que ajudassem o educando em seu processo de aprendizagem eram utilizadas. Assim, ia do sintético para o analítico, do analítico ao sintético, o fônico, o silábico, a palavra, o som. O alfabeto, as letras, as vogais, as consoantes, a maneira como cada um percebia e elaborava todas essas informações. Utilizávamos letra bastão, a recomendada para a fase inicial da alfabetização, ela facilita a percepção das letras na palavra escrita, mas não nos prendíamos a ela quando havia alguma solicitação dos educandos querendo saber como se utiliza a letra cursiva. O alfabeto ficava exposto na sala em forma de cordel, pendurado embaixo do quadro-de-giz. O cuidado constante era o de não perder a contextualização do estudo, era manter a conexão, fazendo sempre a religação do movimento da parte ao todo e do todo à parte.

Maria F um dia falou se referindo às vogais: "Professora, essas letras são poderosas". Fiquei contente, Maria F, que nem conhecia as letras do alfabeto, já estava conhecendo e fazendo distinções, percebendo a presença das vogais em todas as sílabas. Isso era muito bom, porque eu achava delicado explicar o que era uma vogal e o que era uma consoante, articular os sons em meio a infinitas possibilidades. Para melhor compreender essa articulação do som pelo corpo humano, menciono Schwenk (1982), autor que estuda a água em outras dimensões simbólicas culturais e espirituais, além dos aspectos físicos, quando explica sobre a laringe dizendo que esse órgão dispõe de motricidade que permite nuançar o sopro por meio de figuras móveis audíveis na voz, no timbre e na palavra. Dessas articulações sonoras vão surgir as vogais e as consoantes e o autor explica esse surgimento a partir dos movimentos combinados do ar e da água. 
As vogais e as consoantes se fundem e se transformam em um conjunto sonoro ao qual chamamos de palavras, com representações semânticas próprias, que se articulam em frases carregadas de significados e de sentidos. (FRANCO, 2012). Observei que a Alfabetização é, portanto, um processo muito complexo e amplo, ela perpassa pela subjetividade e se manifesta pelas vias das histórias de vida e dos sentimentos de cada educando. A alfabetização de adultos vem acontecendo no Brasil de diversas maneiras, pois cada grupo alfabetizando requer uma maneira própria de aprender, a partir de sua realidade, porém a experiência proposta a esses catadores os envolveu em uma interação com a EA. A EA nesse contexto vai levar à conexão com a EP, com a coleta seletiva, a reciclagem, a cooperativa. Uma cadeia de elementos interligados que circundam o mundo moderno e envolve todos nós.

\subsubsection{Eco-oficina integradora}

Essa oficina foi proposta com a intenção de envolver a turma em uma vivência de ecologia profunda. Capra (1996) Ela se consistiu em uma sequência de ações interconectadas a partir da roda de sensibilização, com respiração profunda e consciente, fazendo conexão com o reino vegetal pelo ar que respiramos. Em seguida, foi apresentada, em data-show, a imagem do corpo humano com a circulação sanguínea e o coração pulsando. Comparamos com a imagem das bacias hidrográficas, alimentadas por córregos e rios e também vimos diversas imagens da espiral na natureza e no corpo humano. Em seguida, com uma lupa, observaram as folhas de diversas plantas e flores que levei para a sala, para perceberem a semelhança entre esses sistemas circulatórios: do corpo, da água e dos vegetais. Após as trocas de informações geradas pelas percepções de cada um, se expressaram com desenhos livres, utilizando tinta à base d'água e papel chamex.

O objetivo dessa oficina era fazê-los perceber o quanto somos filhos da natureza, o quanto trazemos em nós, em nosso corpo, a mesma matriz geradora da vida. Uma experiência de ecologia profunda que gerou mudanças na relação dos educandos com a natureza, a partir dessa vivência eles começaram a perceber a presença da natureza no ambiente em que habitam, sendo esse um passo inicial para uma mudança de atitude diante da vida e para o fortalecimento do pertencimento. No diário de campo da Naná ela comentou a sua impressão sobre essa eco-oficina dizendo que foi

(18) [...] muito grandiosa esta aula e bom para os alunos saberem da importância das flores e das coisas miúdas da natureza. Os alunos acharam ótima, apesar do esforço dos alunos, a aula foi muito produtiva. Os alunos 
gostaram da ideia da pintura e usaram toda sua criatividade na sala de aula [...].

Figura 41 - Eco-oficina de elos

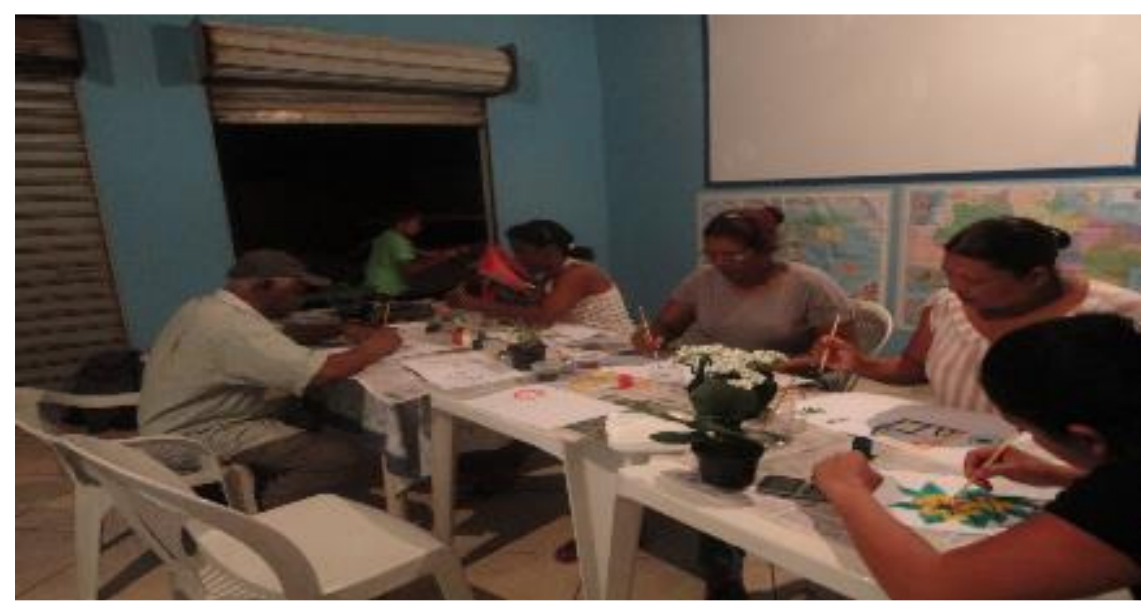

Fonte: Acervo da pesquisa. Agosto de 2014.

\subsubsection{Oficinas de mandalas}

A cooperativa recebia uma grande diversidade de resíduos e a riqueza desse material me estimulava a imaginação, olhava para a cooperativa enxergando muitas possibilidades de produções artísticas que poderiam ser feitas a partir daqueles resíduos. A minha falta de conhecimentos no mundo das artes plásticas me levou em busca de uma parceria com uma pessoa dessa área, a fim ampliar as possibilidades de produções artísticas com os resíduos. Contei, então, com a preciosa ajuda de uma professora de artes da Faculdade de Artes Visuais (FAV) da UFG e de sua orientanda. Essa professora estava com uma orientanda da licenciatura procurando um campo de pesquisa para fazer o TCC. O TCC de Biano (2014) nasceu do mesmo campo compartilhado. Iniciei aí uma nova parceria que foi muito importante para o desenvolvimento do trabalho. Começamos a pensar em como criar artesanato com os resíduos, para mostrar aos educandos catadores outras possibilidades de geração de renda e reutilização daquele material, além de desenvolver atividades artísticas que trabalhassem com a imaginação e a criatividade.

Havia uma diversidade de material que poderia ser utilizado de diferentes maneiras. Vidros, latas, embalagens tetrapac, garrafas pet, papelão, papel. Pensamos em oficinas trabalhando com toda essa diversidade. Chegamos a organizar o material para fazermos a oficina de reciclagem de papel, mas não houve agenda para ela. $\mathrm{O} C D$ era um material abundante na cooperativa, então, surgiu a ideia de fazer mandalas com os CDs. Fizemos uma 
lista e saímos para comprar o material para as produções artísticas. Tintas PVA, tintas específicas para vitral, pincéis, lixa, guardanapos estampados, fitas coloridas, linha de nylon.

Iniciamos o trabalho. O resultado foi surpreendente, produziram lindas mandalas. Foi surpreendente também, porque o trabalho com a mandala trouxe outros resultados além da beleza da plasticidade visual. Durante o momento da realização das mandalas havia um clima de serenidade no ambiente, às vezes intervalos de silêncio surgidos espontaneamente. $\mathrm{O}$ primeiro passo era a limpeza do $\mathrm{CD}$, deixando-o transparente. Depois, a fase da pintura. A coordenação motora fina foi rapidamente desenvolvida com a utilização de pincéis delicados, em traços finos. A técnica de pintura das mandalas era desenvolvida em dois dias, porque precisava fazer a secagem da tinta de relevo, para depois usar a de vitral. Assim, em uma parte da aula fazíamos as mandalas e na outra fazíamos as atividades de leitura e escrita e, às vezes, o jogo da flor das palavras.

As mandalas estiveram muito presentes no trabalho desenvolvido na turma. Não foi algo previamente programado, elas surgiram a partir de minha observação à grande quantidade de CDs que chegavam à cooperativa. Assim que iniciamos o trabalho na sala de aula alugada, começamos a produzir mandalas a partir do reaproveitamento desses CDs. Essa foi uma experiência que deu muito certo e trouxe resultados surpreendentes. As mandalas produzidas ficaram expostas na sala durante todo o período das atividades. Seu J conta como se sentiu fazendo as mandalas: "Fazendo as mandalas eu me sentia como uma criança bem pequenina. Eu já tô um velho, caducando. Achei bom porque vocês gabaram, diziam que tava bom".

As mandalas são carregadas de simbolismos e compostas de elementos que, no conjunto, tornam-se uma expressão de quem as criou. Ao trazer para cá a imagem da mandala, não o faço com a intenção de adentrar em qualquer análise dos sujeitos por essas vias, embora elas manifestem as subjetividades, mas isso acarretaria em outras abordagens que, mesmo muito significativas, não é o foco deste estudo. Trazer a imagem das mandalas, portanto, é apenas como uma maneira de criar uma representação simbólica de uma aprendizagem que foi significativa para todos nós.

As mandalas são uma manifestação muito antiga da humanidade e possuem alguns elementos que são comuns a todas. Assim, a forma circular é uma regra, o ponto central é outro elemento sempre presente, a simetria das formas é uma constante e elas são fechadas por uma linha contínua que a divide em parte interior e parte exterior. Segundo Fioravanti (2003, p. 7-8) 
Numa mandala, o espaço interior, onde as formas se desenvolvem, é sagrado, aquilo que está fora desse espaço é profano. A linha circular é, portanto, o limite entre o divino e o mundano, entre a consciência e a inconsciência, entre a alma e a matéria, entre a união e a desagregação. A linha circular é uma fronteira.

No interior da mandala há um ponto central, que representa a essência da mandala. Os outros elementos em geral parecem estar em ligação com esse elemento e de certa forma dependem dele, pois se desenvolvem a partir da sua existência.

As mandalas fazem pensar em energia, em algo misterioso e isso as tornam uma atração universal, remetendo ao sagrado. Como praticante da dança circular, eu não poderia deixar de mencionar que vem daí também a minha relação com as mandalas. A dança circular é uma expressão da mandala, ela se organiza sempre a partir de um núcleo e as pessoas são o corpo que dão a simetria das formas enquanto dançam, numa relação entre o sagrado e o profano. Fioravanti (2003, p. 9) explica que no oriente as mandalas atendem a motivações religiosas, enquanto no ocidente as mandalas servem mais para enfeitar e que poucos têm noção de sua importância vibracional. Assim, elas possuem tanto usos sagrados quanto profanos. A compreensão de sagrado que melhor se assenta com o teor deste estudo está relacionada ao que Nicolescu (2000, p. 147) apresenta:

O sagrado é o que liga. O sagrado se une, pelo seu sentido, à raiz etimológica da palavra "religião" (religare - "tornar a atar"), mas ele não é atributo de uma única religião. Certa vez Mircea Eliade afirmou em uma entrevista: "O sagrado não implica em acreditar em Deus, em deuses, ou espíritos. É ... a experiência de uma realidade e a origem da consciência de existir no mundo". O sagrado é antes de tudo uma experiência, portanto é traduzido por um sentimento - o sentimento "religioso" - daquilo que liga seres e coisas e, consequentemente, induz nas profundezas do ser humano um absoluto respeito pelos outros, com os quais ele está ligado por estarem todos compartilhando uma vida comum numa única e mesma Terra.

As imagens suscitadas pela pesquisa, a partir do campo e de todos os elementos acoplados, me fizeram imaginá-la na perspectiva de uma mandala. A sala de aula como o elemento central, o sagrado, o que liga, o ponto de onde emanam os elementos que se despontaram definindo o desenho, a cor e a textura, em movimentos sistêmicos entrelaçados e contínuos, uma dança. 
Figura 42 - Encontros com mandalas
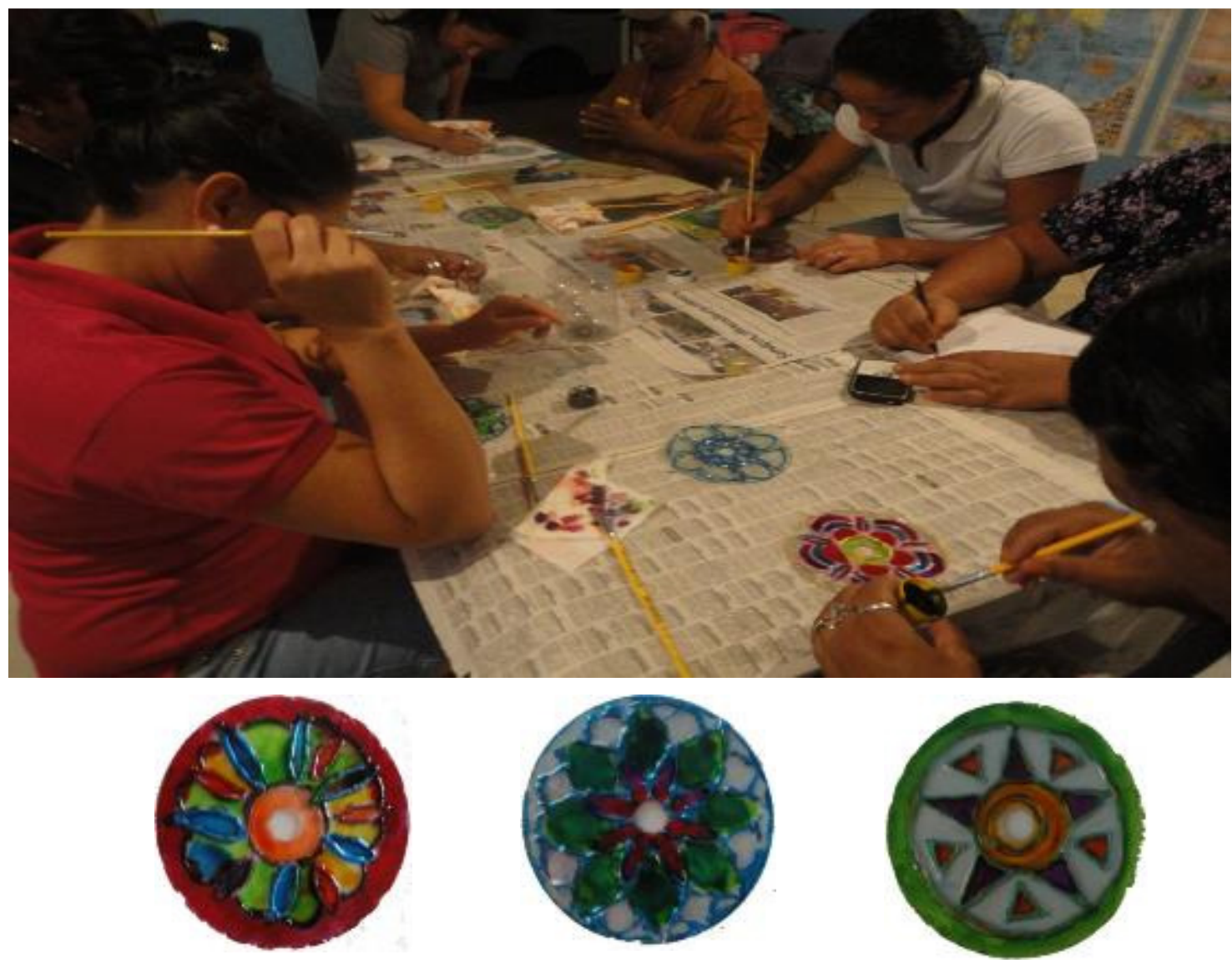

Fonte: Acervo da pesquisa. Agosto de 2014.

\subsubsection{O encontro em Flor de Palavras}

Este foi o nome como batizamos um jogo que criamos para trabalhar a escrita, que nasceu no processo de alfabetização, de leitura e escrita das palavras. A partir das atividades de escrita, me ocorreu criar um jogo para diversificar e dar um clima de descontração que transformasse o aprendizado em algo dinâmico, movimentado e divertido. Então, as palavras passaram a fazer parte de um jogo, criado junto com a turma, para trabalhar o processo de aprendizado da leitura e da escrita. No jogo, cada educando recebia um botão de flor, que era representado no quadro-de-giz com o desenho de uma bolinha. Um educando pensava uma palavra, pedia ajuda em segredo ao educador, colocava no quadro um tracinho correspondente a cada letra e, em seguida, cada colega ia dizendo uma letra. A cada acerto uma pétala da flor se abria, até que a palavra fosse formada. Era a Flor de Palavras. Uma mandala se abrindo em flor. 
Figura 43 - Mandala em flor

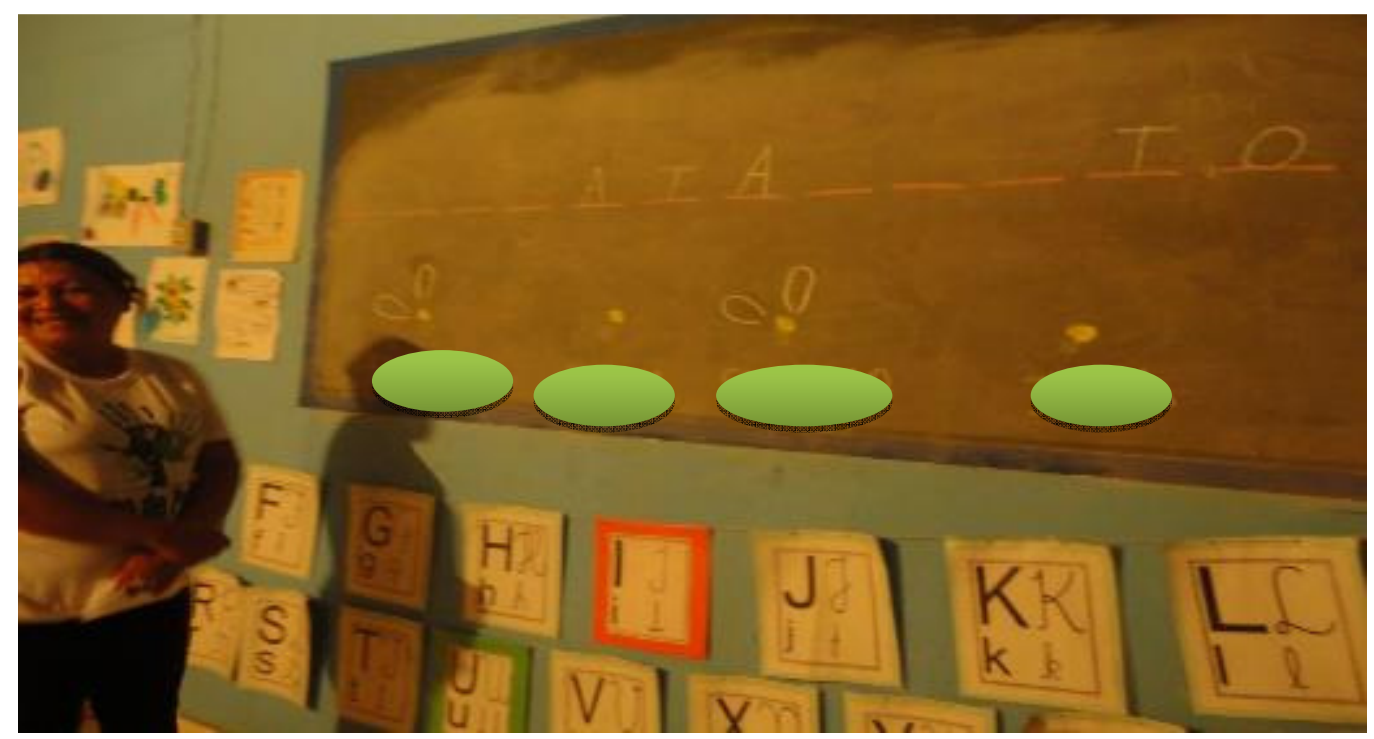

Fonte: Acervo da pesquisa. Setembro de 2014.

\subsubsection{O encontro com a água}

A água foi abordada sob diversas dimensões: da água que circula em nosso corpo à água que circula no planeta, passando por todos os seres e por tudo que constitui a vida no planeta Terra. Portanto, uma sensibilização para a importância da água na manutenção da vida. A influência da água nesta pesquisa se deu em decorrência de minha participação no grupo de estudo O Caos Sensível, sobre o movimento da água e do ar na constituição do ser, a partir do livro de SCHWENK (1982), T. Le chaos sensible: creation de forms par les moviment de L'eau et de l'air, no Centro de Referência em Educação Integral e Ambiental (CREIA) e Instituto Caliandra, sob a coordenação das professoras Yara Magalhães e Vera Catalão. Por isso, era hábito fazermos nossas comemorações e celebrações brindando com água. A gratidão era um sentimento sustentado no grupo e a água permeava esse sentimento ao ser vista como geradora da vida. Olhávamos para a água, na sala, colocada na garrafa e nos copos. Depois, essa água era bebida gole por gole, devagar, sentindo o seu sabor, o seu percurso no corpo. Eu levava diariamente a água que bebíamos, pois na sala não tinha filtro. Os educandos comentaram que a água da torneira já era tratada, pronta para beber. Percebi que eles não utilizavam água filtrada, das crianças aos adultos, todos bebiam água da torneira e isso para eles era normal, cultural.

A partir dessa revelação, utilizamos filmes e imagens diversas mostrando e falando sobre a água no planeta, sobre a necessidade de cuidarmos da água como um bem precioso para a vida. A intenção era fazê-los conhecer que precisamos saber nos relacionar com a água e que, para beber, é importante filtrar a água para prevenir doenças provocadas por 
verminoses, alertando para o cuidado com as crianças. Dessa discussão, fiz a doação de filtros de barro que gerou uma aula sobre como fazer a limpeza, a montagem e a manutenção. As palavras geradas iam sendo escritas no quadro, com a colaboração da turma. Dessas conversas, mencionamos a presença da água em nosso ambiente e o quanto que ela se relaciona com a energia que está presente em cada ambiente. Ambientes calmos, ambientes agitados, ambientes carregados. A turma gostava dessas analogias e cada um contava uma história.

Figura 44 - Água de beber

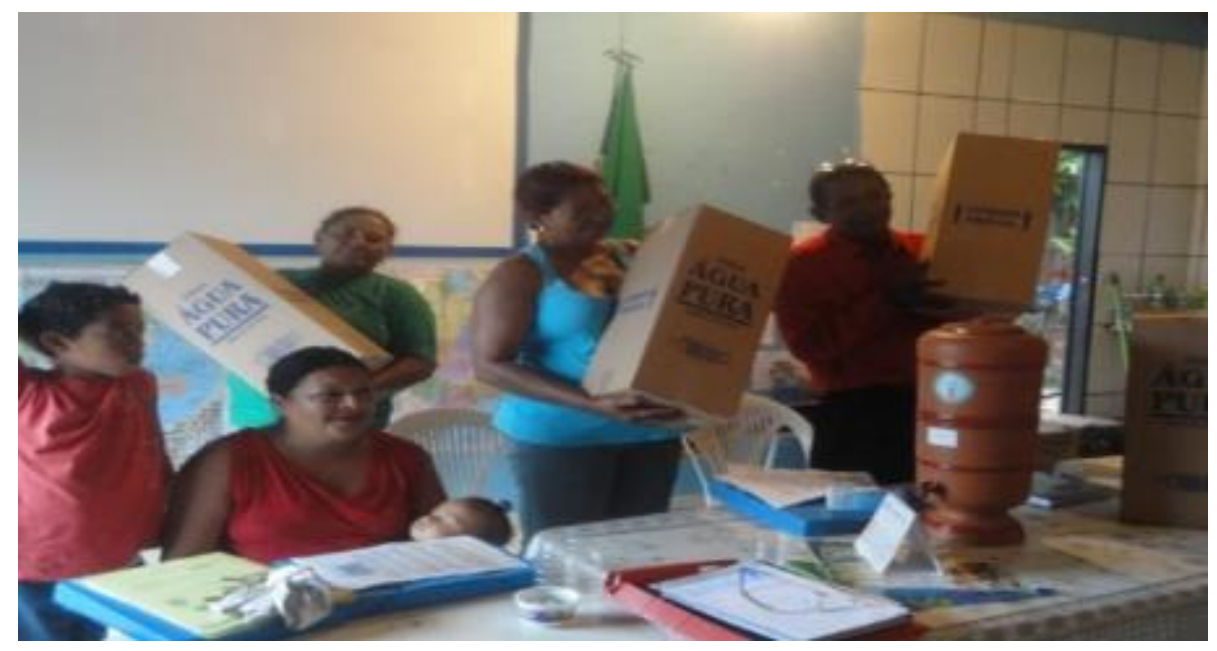

Fonte: Acervo da pesquisa. Outubro de 2014.

A partir do olhar para a água, comecei a preparar a turma para uma visita ao Córrego Caveirinha. Esse córrego passa margeando o setor, está presente no convívio das pessoas daquele lugar, que necessitam atravessá-lo todos os dias para levar as crianças à escola. Com a utilização do data-show, apresentei imagens do Córrego, desde sua nascente até o ponto onde deságua no Rio Meia Ponte. Apreciamos o Córrego, vimos o seu tamanho, a sua extensão, falamos sobre a água, a mata ciliar, o assoreamento. Marcamos a data e fomos fazer a visita ao córrego. Diferente de passar sem olhar para ele, nesse dia os olhares estavam voltados para o Caveirinha. O grupo percebeu o quanto ele estava maltratado, sem mata ciliar, desbarrancando, com as águas sujas e servindo de depósito de rejeitos. Havia caminhões despejando entulho em uma área de nascentes.

Aquela situação comoveu o grupo e daí surgiu a ideia de fazermos um abaixo assinado para encaminhar uma denúncia ao Ministério Público para que alguma providência fosse tomada. A denúncia foi feita junto ao Ministério Público, que se limitou a encaminhar para a Agência Municipal do Meio Ambiente (AMMA), a fim de que fosse averiguada. Fui convidada e acompanhei a diligência. Após a inspeção da AMMA, nada mais foi feito. Esse 
precisava ser um movimento da organização da comunidade para se fortalecer e implementar ações em defesa daquele córrego, mas essa seria mais uma luta a ser incorporada a tantas outras daquela comunidade. O córrego precisa ser cuidado e o cuidado se inicia por quem com ele convive. A caminhada serviu para que a comunidade olhasse para o Caveirinha e esse é o primeiro passo para se inquietarem com essa situação e iniciarem alguma mudança.

Figura 45 - A terceira margem

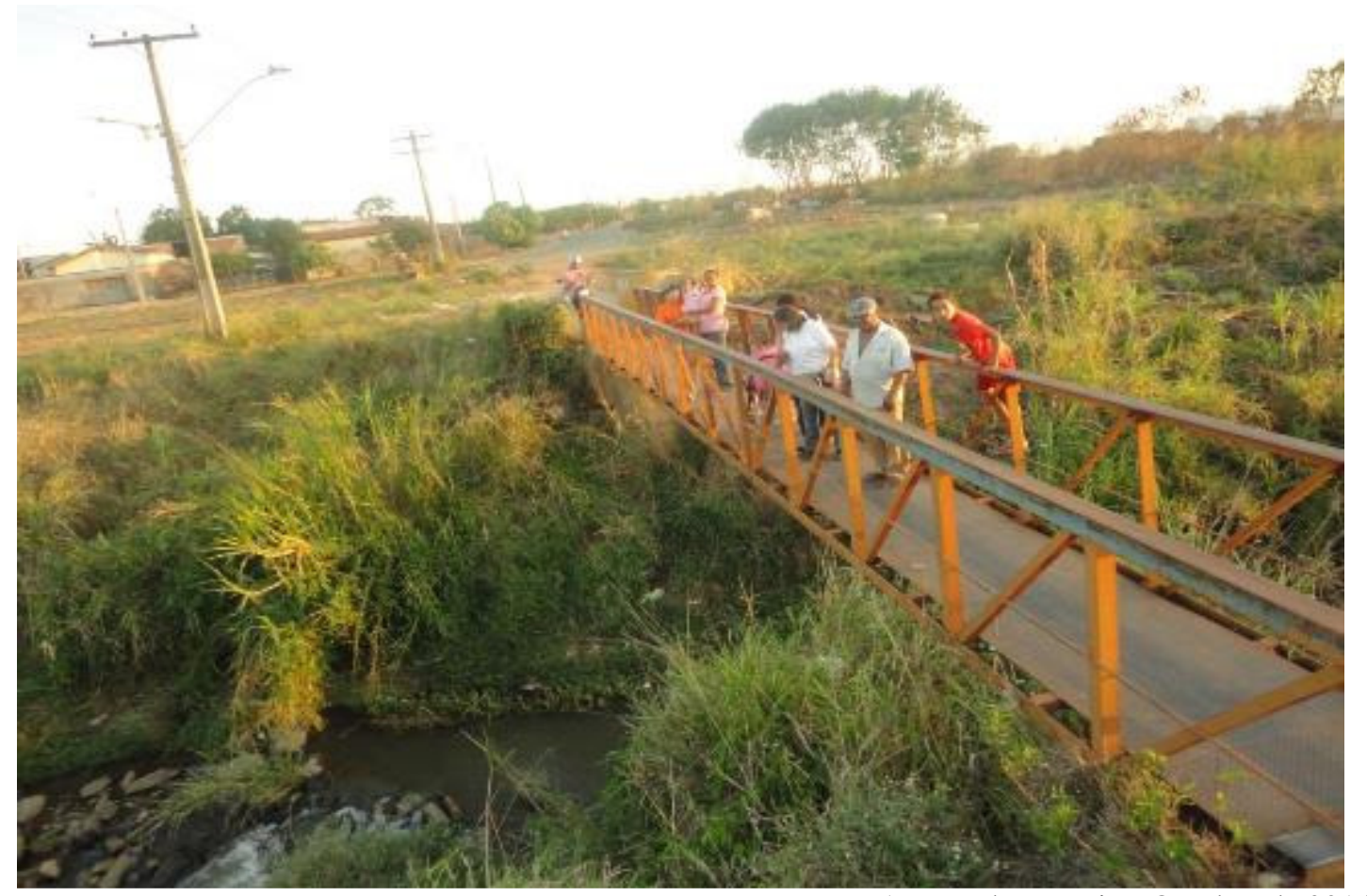

Fonte: Acervo da pesquisa. Outubro de 2014.

\subsection{5 $\underline{O}$ encontro com o cerrado}

Buscando aprofundar o entendimento da relação entre a natureza e a vida, desenvolvi estudos sobre o cerrado e os povos do cerrado. Novamente o uso do data-show foi muito importante, pois pude levar imagens dos povos indígenas e quilombolas: os cantos, as danças, a cultura e também filmes e imagens do cerrado. Levei vários livros para a sala, literários e científicos. Livros bonitos, com texto e ilustrações. A turma gostava de olhar as imagens, elas traziam identificações com suas histórias de vida, riam, contavam histórias, tentavam ler as palavras. Dentre os livros que levei estavam: O Piar da Juriti Pepena. (BARBOSA, 2014); O jardim da vida (BRANDÃO; ROCHA, 2004); Enciclopédia da natureza (DE BECKER, 2008); Pai do Mato (GALHARDO, 2012). Dentre os vídeos, DVD, ressalto Icologia (ÂNGELO; LIMA, 2004) e Catador de Sonhos (GIOVANI LORENZETTI, 2007). 
Convidei os catadores da cooperativa para um momento de integração com a turma na sala de aula, assistindo os vídeos Catador de Sonhos e Icologia. Catador de Sonhos é um documentário cujo personagem principal é Seu Iramar, o presidente da Acop, em sua lida como catador na cidade de Goiânia, Goiás, quando eles ainda moravam na favela. Icologia é outro documentário que tem como personagem principal o Seu Ico, um morador do campo, no município de Pirenópolis, Goiás. Era uma analogia entre os dois personagens. Compareceram vários catadores, até o seu Iramar. A sala ficou cheia, afastamos a mesa, colocamos uma esteira no chão, todos foram acomodados. Ao final, deixei o grupo à vontade, caso quisessem fazer algum comentário. Maria F falou que aquele filme do Seu Ico dava um sentimento bom dentro dela. Não teve mais nenhum comentário, ficaram silenciados. Nem Seu Iramar, não falou nada, pareceu que ele estava preocupado com alguma situação, havia ficado boa parte do tempo trocando mensagem no celular e saiu logo. Os outros catadores agradeceram e foram embora.

O que o silêncio nos dizia? Entendi que as vozes de dentro podiam estar falando mais alto em cada um, pensando e comparando os dois personagens principais: Seu Ico e Seu Iramar. Esses personagens estavam envolvidos em contextos bem diferentes, contextos dos vários mundos daqueles catadores, espelhos de todos eles. Em um repousava uma visão romântica da natureza, embora real, e em outro uma visão urbana das relações de consumo que nos consomem. Para aqueles catadores, esses são os mundos entre os quais se encontram, o do campo, de onde vieram, e o urbano do catador. Que sentimentos os teriam envolvido? A que mundo pertencem? Com certeza não é ao mundo que desejam, mas ao mundo que lhes restou no que lhes resta do universo das relações de injustiças sociais que nos absorve.

As imagens das plantas e das árvores eram motivo de muita conversa, trocavam conhecimentos sobre elas, cada um com sua ciência. Para o aprofundamento desse estudo sobre o cerrado, visitamos o Memorial do Cerrado. Consegui o transporte com a Incubadora e paguei o ingresso de cada um. A visita foi no dia 05/11/2014. Foi um grupo de 13 adultos e 5 crianças. Além dos educandos da turma, foram alguns catadores da cooperativa. Essa visita foi muito importante para a turma e todos gostaram muito. Encontraram-se pessoalmente com o professor Altair Sales que já o conheciam do livro O Piar da Juriti Pepena. Fizeram fotos com ele. Seu F se emocionou ao encontrar uma casa de barro e coberta de palha, disse que era igualzinho a casa que ele morava na roça. Pediu para fazer um foto dele ali. Depois ensinou como fazer rapadura, na casa do melado de cana. No final, fomos para um recanto, embaixo de frondosas mangueiras carregadas de frutos, onde lanchamos. Eu havia levado o lanche para a turma. A partir dessa visita, fizeram lindas produções de desenho, pintura e colagem com 
sementes, flores e folhas secas, gravetos e areia colorida, utilizando grandes cascas de palmeiras como suporte. Enquanto conversavam sobre o que viram e sentiram, faziam as produções. Gostaram muito da história do livro Pai do Mato, Seu J e Seu F se entretinham em longas conversas a partir dessa história, contando as lendas que cada um conhecia.

Figura 46 - Memorial do Cerrado com professor Altair Sales

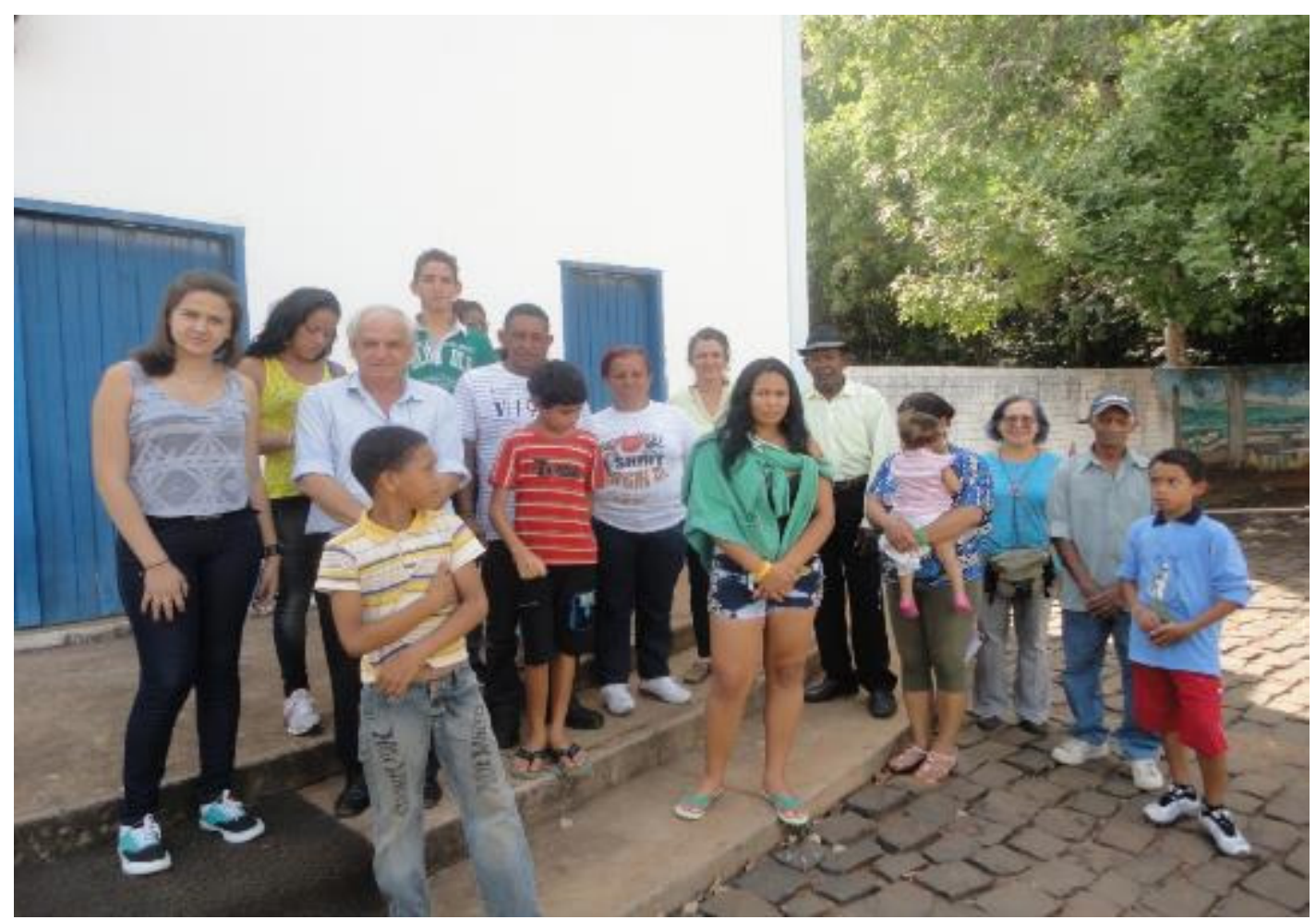

Fonte: Acervo da pesquisa. Novembro de 2014.

\subsection{6 $\underline{O}$ encontro com as criancas}

A turma era muito frequentada pelas crianças da comunidade. Tinham as filhas dos educandos da turma e as outras, dos outros catadores. Maria P levava a sua filhinha pequena todos os dias e o seu filho Pp, de 12 anos, para cuidar da pequena enquanto Maria P fazia as atividades. Maria S costumava levar a sua netinha também. Havia C, que era filho de Maria M e U, que era filha de Naná. Os filhos de F Catador também frequentavam a turma. Tinha dia que a sala ficava movimentada com a presença das crianças, eu conversava com elas, explicava que era a hora da aula dos adultos, pedia a colaboração. Eles entendiam, por último já entravam na sala sem fazer barulhos. Uma noite, $\mathrm{C}$ estava brincando, rolando um carrinho em volta da mesa onde o grupo estava estudando. Maria $\mathrm{F}$ falou que assim era difícil, que $\mathrm{C}$ estava movimentando as águas da sala. Rimos, o grupo percebeu que ela estava utilizando um 
conhecimento novo, adquirido dos nossos estudos. Aquela maneira espontânea demonstrava a percepção de Maria $\mathrm{F}$ na relação com a água e a apropriação de um saber procedente das estratégias da EA.

No Dia das Crianças fizemos uma festa para as crianças que frequentavam a turma. Preparei lanchinho e lembrancinhas para 15 crianças. Fiquei surpresa com o tanto de criança que apareceu. Perdi a conta. Todos lancharam, participaram com alegria. Um sobrinho de Naná, que gostava de ler gibi que o pai levava da cooperativa pra ele, contou várias histórias. O seu J se revelou um grande contador de histórias, as crianças se sentaram no chão para ouvirem as histórias. Riam, se divertiram.

Figura 47 - Encontro com as crianças

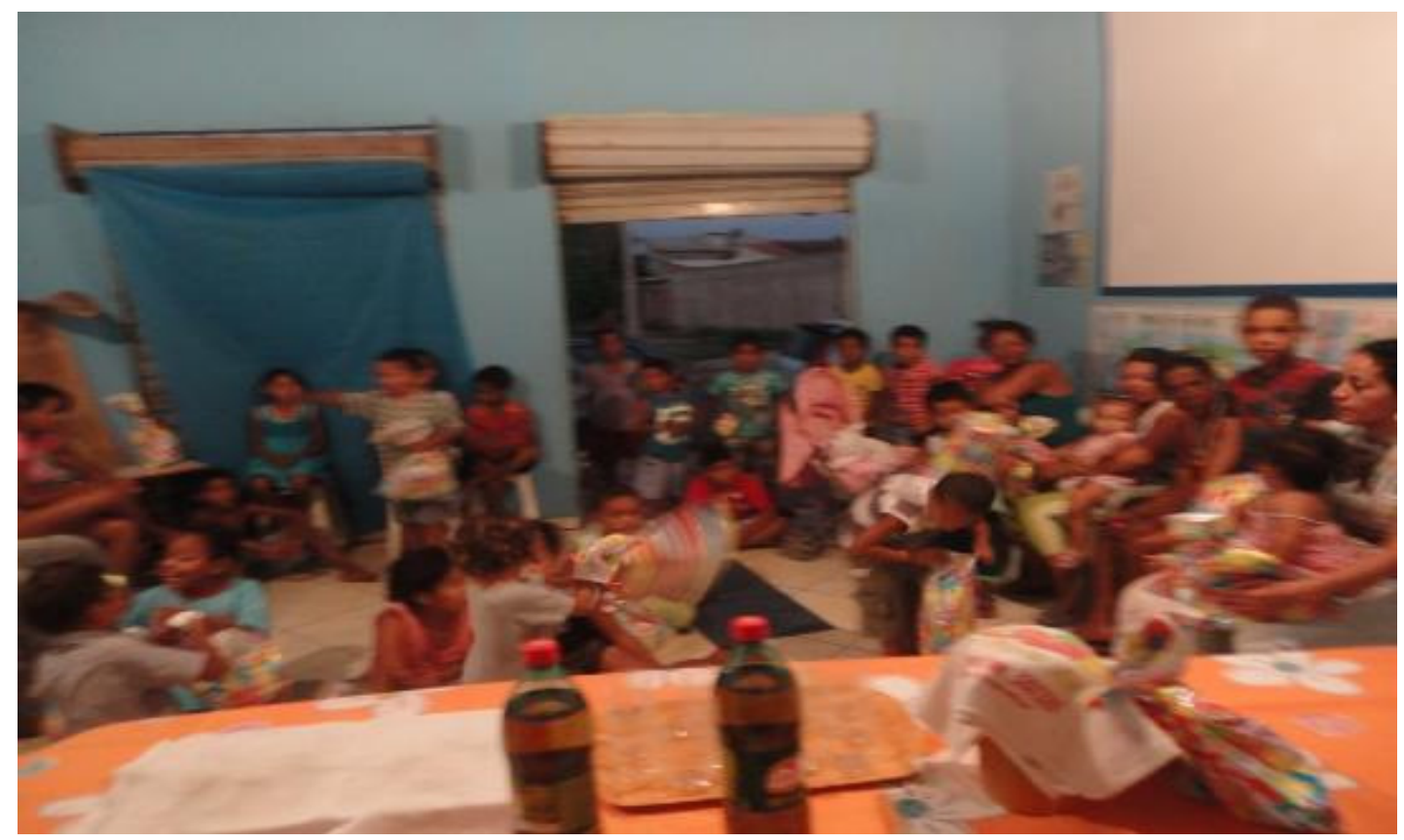

Fonte: Acervo da pesquisa. Outubro de 2014.

\subsubsection{Os "benefícios"}

O que estou chamando de 'benefícios' são alguns elementos que se agrupam sob este tema, ou seja, elementos que chegaram a esses educandos pela conexão com o trabalho realizado. Basicamente foram dois: a cesta básica de alimentos e os óculos. Logo no início, preocupada em fazer com que os educandos se interessassem em participar da turma, consegui, junto com a Incubadora Social da UFG, uma instituição ligada ao Programa Fome 
Zero $^{25}$, que forneceria uma cesta de alimentação mensalmente aos educandos. O projeto que apresentei foi aceito, mas a burocracia para efetivar a parceria dificultou o processo e somente no final do ano consegui fazer a entrega de uma cesta.

Ao longo do processo, fui me dando conta de que as pessoas daquela comunidade já estavam habituadas a receberem esses benefícios sociais. Soube que ao longo do ano eles recebiam mensalmente uma cesta básica distribuída por uma instituição filantrópica, que não consegui identificar. Ao comentar sobre a turma, Maria S menciona os benefícios recebidos: "Pra mim foi um convite muito agradável, porque eu tenho aprendido muitas coisas e ganhei uns benefícios também, né." Parece que a presença desses 'benefícios' influenciam, de fato, o interesse em participar da turma. É a vida vivida no limite da sobrevivência.

A chegada de cestas básicas era sempre bem vinda. A alimentação ali era limitada, comiam o mínimo necessário para viver, senão até menos. A fome rondava o ambiente. Quando chegava a merenda da turma, ela era servida às crianças também. Maria F comentou que é costume naquela comunidade darem um prato de comida para uns e outros que de vez em quando não têm nada para comer em casa. E Maria A declarou que "A coisa pior que tem na vida de um ser humano é a barriga roncar." A miséria parece ser mesmo um problema insolúvel na humanidade, que vem acompanhada da fome.

A fome, problema com distribuição planetária, ultrapassou os séculos XIX e XX e prenuncia sua permanência no século XXI como expressão máxima de um modelo societário que não consegue solucionar os entraves que perpetuam os bolsões de miséria do mundo, aumentando-os gradativamente. (NOAL, 2003, p. 83)

A situação vivida naquela comunidade era uma expressão dessa realidade da fome que se distribui em todo o Planeta. Uma realidade que vem conectada à exclusão, à ganância, à exploração do homem pelo homem, ao desrespeito, ao modelo de sociedade capitalista submisso aos interesses do grande capital, que se alimenta da degradação da natureza e da vida humana. É desse contexto desumano que essa comunidade torna-se vítima, numa relação arbitrária, injusta e desonesta, com a qual não podemos nos acomodar.

Os grandes grupos que se ocultam por detrás das doações de cestas básicas, eventualmente saciam a fome do intervalo entre uma refeição e outra daquelas pessoas, enquanto alimentam a teia do grande capital que se nutre dessa relação injusta. Esses grupos

\footnotetext{
${ }^{25}$ O Programa Fome Zero foi criado pelo governo federal brasileiro em 2003, para o enfrentamento da fome e da miséria.
} 
não se aproximam daquelas pessoas, não entram na comunidade para conhecê-la por dentro e saber quem é F Catador, quem é Maria M, quem é Maria P, Seu M e Seu F. Não buscam saber quais são as reais necessidades daquela comunidade e cooperar com a construção de melhores condições de trabalho, para que tenham uma vida digna, para que tenham a condição também de participar da sociedade como cidadãos de direitos, usufruindo dos mesmos direitos de todos. Seu Iramar, em entrevista para esta pesquisa, comenta sobre o que precisam para viver com dignidade:

(19) É, a cooperativa de catadores já tem um diferencial: capitalismo mesmo nós não temos, de investimento. Tem que ser uma associação com possibilidade de sustentabilidade, se tiver investimento. Nós tem capacidade de ser auto-sustentável. Pra nós ter auto-sustentabilidade na gestão do nosso trabalho, tem que ter investimento de equipamento, de esteira, de funil, de balança, de prensa, caminhão... Tudo isso influi no processo e facilita a gestão nossa de trabalho e com dignidade.

Figura 48 - Benefício é sempre bom

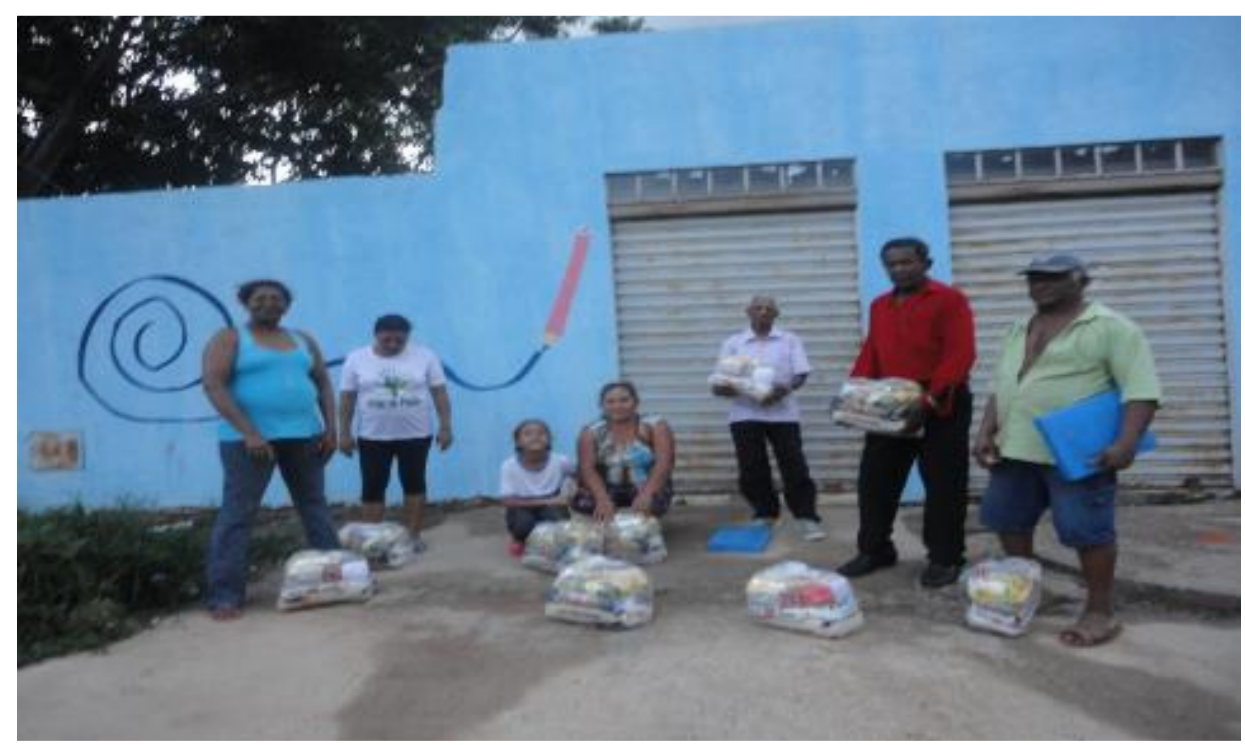

Fonte: Acervo da pesquisa. Dezembro de 2014.

\subsubsection{Os óculos}

Além da cesta básica, os educandos receberam óculos por meio de um convênio do Programa AJA-Expansão com o Programa Boa Visão, da Fundação Jaime Câmara. A aquisição desses óculos demandou que os educandos passassem por exames oftalmológicos, esses exames foram encaminhados pelo CEROF, Centro de Referência Oftalmológica do Hospital das Clínicas da UFG. O encaminhamento de todos os procedimentos se transformou 
em uma novela à parte e era uma demanda atribuída ao educador popular. Fiz o levantamento na turma de quem precisava de óculos. Maria M, Maria S, Maria F e Seu J se manifestaram. A consulta inicial foi marcada junto, para todo o grupo. Expliquei onde deveriam ir e como fazer para chegar. A situação foi transformada em palavras, em aula. Maria F comentou toda satisfeita que ficou feliz quando chegou em frente ao prédio leu, CEROF, e entendeu tudo.

A partir da primeira consulta, foi dado um encaminhamento diferente para cada educando. Maria F e Maria M tinham que fazer um exame específico de fundo de olho, mas o aparelho do CEROF estava quebrado, então foram encaminhadas para uma clínica particular. Tive que fazer os contatos com essa clínica, o exame era caro, R\$120,00 para cada olho, com desconto por ser daquele convênio. Liguei em outras clínicas da cidade, todas muito mais caras. Fizeram o exame, entrei no rateio cobrindo uma parte. Depois de muitos encaminhamentos, conseguiram receber os óculos. Com Maria S foi mais simples, ela recebeu a receita e encaminhou os óculos. Seu J precisava fazer a cirurgia de catarata, então, foi encaminhado para exames cardiológicos preparatórios. Seu $\mathbf{J}$ falou que não tinha quem o acompanhasse, chamei a sua filha e expliquei-lhe a situação. Ele conseguiu uma moça da comunidade a quem ele pagou para que o acompanhasse. Fez os exames, o cardiologista o encaminhou para um tratamento, no início de 2015 ele refez os exames e conseguiu fazer a cirurgia.

Depois de tudo resolvido, o Seu F e, em seguida, o Seu M resolvem participar da turma. Foram estimulados por verem que os educandos haviam recebido os óculos e até cirurgia de catarata. Assim que Seu F entrou, me disse que precisava fazer a consulta de vista. Pensei que não fosse mais dar tempo, mas liguei e consegui ainda encaminhá-lo. Em seguida chegou o Seu M. Fiz novo contato e consegui encaminhá-lo também. Seu F recebeu a receita e foi encaminhado para fazer os óculos, Seu M foi encaminhado para cirurgia de catarata e os procedimentos já estavam marcados para 2015.

A aquisição dos óculos colaborou muito para o processo de leitura e escrita dos educandos. Especialmente para Maria M, pois ela não estava enxergando as linhas do caderno e quase não via também as letras que escrevia. A sua aprendizagem melhorou muito. Maria M nunca havia feito uma consulta de vista, embora já percebesse há tempo a sua dificuldade para enxergar. As deformações da visão se manifestando de diversas maneiras. Algumas existem no corpo, outras são criadas na mente e se projetam sobre a sociedade em nossas interações. A primeira se resolve, frequentemente, utilizando óculos, mudando as lentes, ou aprendendo a ver o mundo com os olhos da alma, a segunda se enfrenta das diversas maneiras que sejam capazes de ampliar a consciência, a percepção das relações de exploração e do consumo 
devastador e degradante da natureza, assim como ampliar as possibilidades de se relacionar com a vida. Em todos esses ambientes a EA e a EP precisam se encontrar para agirem juntas em defesa de uma sociedade mais justa, de um mundo melhor e mais sustentável, em defesa da vida.

\subsubsection{A formacão}

A experiência de educadora popular era uma aventura nova a que eu estava me assentando. Eu nunca havia atuado como alfabetizadora de adultos. Nesse sentido, acompanhava atenciosamente os ensinamentos da formação continuada do AJA-Expansão, as coordenadoras eram alfabetizadoras experientes e eu sempre aprendia com elas. Aprendia, também, nas trocas de experiência com as outras educadoras populares. Toda $6^{\mathrm{a}}$ feira havia a formação para os educadores populares, no Centro de Formação Paulo Freire, da RME. Eram duas horas de formação, das $19 \mathrm{~h}$ às $21 \mathrm{~h}$. Esses momentos foram importantes para mim, me davam um contexto tanto da cidade, de como estava o atendimento em cada turma, as dificuldades vividas por cada educadora popular, como, também, me davam muita aprendizagem sobre o processo de alfabetização. Fazia as conexões entre os saberes que eu já trazia e os que estavam chegando por aquelas vias. Aprendi muito nessa formação, mas percebi que nossos caminhos às vezes se desencontravam, enquanto uns tentavam abrir outros estreitavam a amplidão do olhar sobre o mundo.

Às vezes, percebia uma compreensão distorcida do que é o trabalho feito a partir da realidade do educando, limitando a abertura do olhar para o mundo, para o planeta Terra, o cosmos. Em um encontro, as coordenadoras estavam sugerindo uma atividade de localização geográfica, no mapa do Brasil, do lugar onde nasceu. Eu sugeri que fosse acrescentado fazer, também, a localização do Brasil no planeta Terra, utilizando o mapa mundi e um globo. A coordenadora me explicou que isso se distanciaria da realidade. Não era possível contra argumentar com objetividades àquela situação, pois ela perpassa por outros caminhos que precisavam ser trilhados por aquela equipe, nem ficaria bem para mim naquela situação, mas já havia comprado um globo para a minha turma. Em outro momento, a sugestão era para criar uma atividade para trabalhar com a identidade e a questão colocada era: "Quem sou eu". Sugeri uma atividade de recorte e colagem de imagens de revistas, material farto nas cooperativas, onde cada um expressasse, por imagens, "Quem sou eu". Imaginei os alunos se identificando em uma flor, uma borboleta, uma árvore, enfim, abrindo a perspectiva 
multidimensional e existencial daquela atividade. A coordenadora disse que não era assim, que era para trabalhar com as informações da carteira de identidade.

Embora essas coordenadoras tenham comprovado experiência como alfabetizadoras de adultos, demonstraram que parecia estar havendo uma compreensão distorcida, ou limitada, da proposta de educação popular de Paulo Freire, com a qual a SME, por meio de suas diretrizes para EAJA, demonstrava estar comprometida. Como não pude participar da formação inicial, não posso agora fazer relações entre essas percepções e a formação inicial realizada com as educadoras populares e as coordenadoras, o que posso considerar é que essa situação revela um distanciamento entre o pensamento que está posto como referência para o trabalho e as estratégias sugeridas na formação continuada. O que é possível assegurar é que a formação é uma via por meio da qual esses assuntos podem ser cuidados e a EA pode trazer grande contribuição, ampliando a noção de pertencimento necessária naquela formação.

Em um momento de troca de informações, comentei sobre a dificuldade que eu estava encontrando para manter os educandos na turma, eu havia acabado de desativar a turma da Coocamare. Achei muito bom o acolhimento que eu recebi do grupo, percebi que houve uma relação de alteridade se constituindo, as colegas estavam entendendo bem o que eu estava vivendo. Recebi alguns retornos das colegas, teve uma que disse que tem uma caixa de bombom para presentear os alunos que comparecem. Fiquei admirada com essa sugestão, me fez lembrar das experiências behavioristas de condicionamento do comportamento humano, mas me fez voltar a refletir sobre o que eu estava fazendo. Afinal, eu estava procurando adquirir uma cesta básica de alimentos para doar a cada mês a quem estivesse frequentando. Não seria a mesma relação?

A coordenadora me falou que uma razão para as dificuldades em formar a turma com os catadores é que eles não percebem o valor do conhecimento, que eles se veem somente como excluídos, que eles precisam se sentir valorizados, perceber o valor da sua função. Embora entendendo não ser essa a única razão, concordei com ela. A noção de pertencimento precisa ser fortalecida. Esse é o início do caminho para a efetivação de uma aprendizagem significativa.

A experiência com os catadores me fez perceber o quanto esses sujeitos são ocultados pelas sombras da sociedade. Uma sociedade que oculta o lixo que produz e os resíduos que acumula, oculta também a fome, a exploração e a exclusão. Se a sociedade inteira não percebe o lixo que produz, não distingue a natureza e também a vida que dela brota, por conseguinte não percebe também o catador. Como fazer com que o catador se sinta valorizado, se a sua profissão é ocultada em toda sociedade? A reversão dessa situação somente pode ocorrer pelo 
caminho trilhado pela EA, um caminho integrativo que reconecta o homem consigo mesmo, com a natureza, com a vida. Caminho que mostra que a única saída está na participação solidária de todos na construção de outro mundo. Um caminho difícil de ser navegado, porque está na contramão das forças hegemônicas que lucram com a guerra, que geram a fome, que naturalizam a exclusão, que matam a vida do Planeta Terra.

\subsubsection{O portfólio}

Os portfólios estão sempre associados a instrumentos de avaliação. Em nosso caso, pela postura de partilha que eu adotava, os portfólios serviram principalmente como objeto de contemplação da criatividade, do empenho, do envolvimento afetivo de cada um, o que, de certa maneira, não deixa de ser um procedimento avaliativo. Mas olhar para os portfólios dos educandos dessa turma é olhar, sobretudo para mim mesma, pois eles são uma significativa expressão do trabalho que desenvolvemos na turma. Levam-me a um diálogo comigo mesma. As atividades realizadas, as maneiras como cada um as realizava, o que foi bom, o que não foi e o que poderia ter sido feito melhor, tudo isso revela a minha postura como educadora, mostrando uma parte do meu ser que se projeta sobre o meu fazer e apresentando parte da minha existência, a minha subjetividade. Vendo dessa maneira, os portfólios são reveladores do entrecruzar de nossas existências, minhas e dos educandos envolvidos. Essa reflexão me leva a pensar no portfólio inserido no terreno específico da EA e tento perceber, a partir da experiência vivida com essa turma, o que seria um portfólio para esse trabalho? O que me faz pensar na noção de um eco-portfólio. E como deve ser um eco-portfólio? Como deve ser um eco-portfólio para catadores educandos que não têm o domínio da leitura e da escrita? Entendo que esse eco-portfólio deve ser aquilo que for possível ser criado a partir da realidade, dos sujeitos, das condições, das posturas adotadas, das sutilezas da EA e, portanto, do todo que se transversaliza pela teia que se constitui em cada lugar.

Os portfólios dos educandos se constituíram, portanto, principalmente, em instrumento de minha própria avaliação. Dessa maneira, revisitar os portfólios foi reviver com emoção nossos encontros; em cada portfólio havia a marca de cada um, do que cada um conseguiu fazer a partir do que lhe foi proposto e do espaço de liberdade e autonomia que havia. Assim, no portfólio de Seu J, dentre outras coisas, estava o seu caderno com cartas que ele gostava de escrever, dando notícias suas, e também outros escritos, presumidamente inspirados em nossas aulas. Um bom exemplo das expressões utilizadas, do cadenciamento e dos seus sentimentos está neste trecho: "O mundo é um jardim de floris / veja bem como e o 
paçado / nois toudos fomos criança / agora estamos na idade (...) Muntas amagura temo passado / fisse tudo para ser bom pai / mais agora estou condenado". No portfólio de Maria M via-se sua evolução na tentativa de escrever as letras do seu nome e, junto, sua maneira inventiva de se expressar com desenhos, já que não sabia ler e escrever. Desenhava sua casa com uma grande árvore ao fundo e ao lado um caminhão de resíduos sólidos descarregando. Ela nutria o desejo de transformar sua casa em uma cooperativa. Nos portfólios de Seu M e Seu F, os treinos para aprender a escrever o nome. Maria F gostava de escrever as letras repetidamente, para ajudá-la a memorizar, assim como escrever também, repetidamente, o seu nome.

Em nossa turma, as folhas de papel chamex ficavam disponibilizadas em local de fácil acesso, para que todos pudessem utilizá-las livremente, mas com consciência ambiental. Ao trabalharmos com as noções de números e numerais, sugeri que fizessem desenhos livres, em chamex, escrevendo o numeral e ilustrando os números, as quantias representadas. Essa foi uma atividade sugerida para fazerem em casa, nos momentos que fosse possível, que acabou sendo feita uma parte na sala. No portfólio de Maria F surpreendeu-me a sua riqueza da expressão artística, a originalidade de seus expressivos desenhos, representando em cada folha a quantia correspondente a cada numeral. Observei que seus desenhos possuíam grande inspiração na natureza: flores, pássaros, árvores tudo bem alegre e colorido. Essa mesma aluna, ao final de uma atividade com um poema escreveu: "Eu sou o sol e você é a lua" e o Seu J escreveu: "O grão no chão produz a lavoura produtiva". Escreviam trocando informações entre eles. A presença da natureza nas expressões dos alunos foi algo que se manifestou nos portfólios. Em todos eles, de alguma maneira a natureza estava presente. Entendo que esta é uma característica específica que deve se manifestar em um eco-portfólio de EA e, junto com essa manifestação, a revelação das transformações vividas por cada um.

No portfólio de Maria $\mathrm{P}$, encontrei um exercício de escrita, onde, no seu esforço pessoal, teceu uma frase que me tocou profundamente: "Dinorá, você é muito especial." Uma manifestação afetuosa que me faz perceber o valor do encontro de nossas vidas, mas, sobretudo, lembra-me que fui a única professora, depois de outras tentativas, que conseguiu manter uma turma de alfabetização naquele lugar. Consegui despertar neles o interesse latente em aprender a ler e escrever. Ser especial é ocupar um lugar específico. Naquele ambiente, havia agora um lugar próprio para mim, que aos poucos está se revelando: qual é esse lugar, como posso continuar ocupando esse lugar? É preciso agir. Maria $\mathrm{P}$ e todos aqueles educandos são também especiais para mim. Juntos, pertencemos a este mundo e queremos 
torná-lo especial. Dessa experiência brotou, além do aprendizado de vida, um profundo amor e uma imensa gratidão.

Figura 49 - Os portfólios

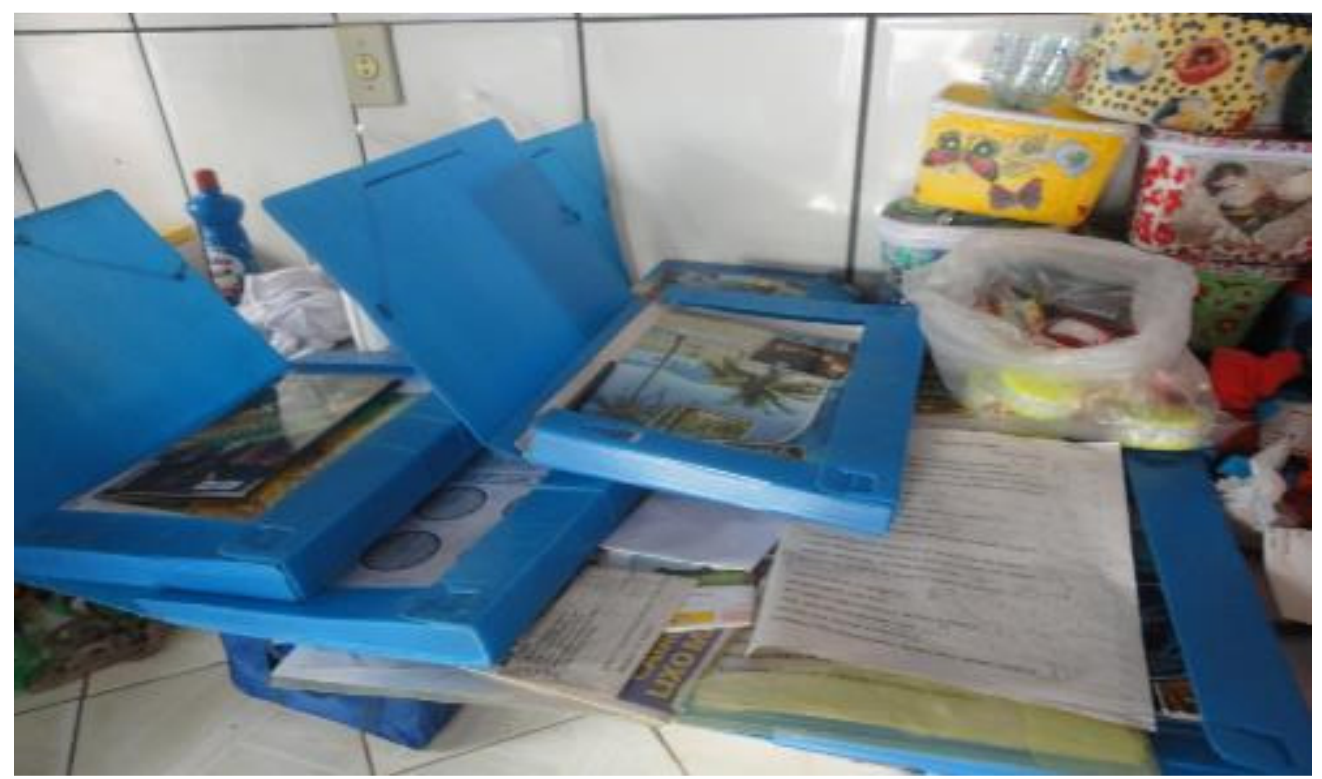

Fonte: Acervo da pesquisa. Dezembro de 2014.

\subsubsection{A transdisciplinaridade}

A prática pedagógica transdisciplinar se manifesta pela postura transdisciplinar do educador. Para que o objeto seja apreendido em toda a sua dimensão cognitiva é necessário que haja observadores transdisciplinares. A postura transdisciplinar foi, portanto, uma exigência suscitada pelo contexto da experiência realizada nesta pesquisa, pois o contexto multidimensional que a envolvia deixou claro que uma postura fragmentária da educação não alcançaria a sua ampla e complexa dimensão manifestada. Sobre essa prática transdisciplinar a explanação de Santos (2009, p. 24) esclarece esse entendimento. Essa autora diz que:

Por sua vez, para se revelar, a complexidade dos fenômenos exige do observador uma postura transdisciplinar. Ou seja, para ser conhecido em toda a sua dimensão conectiva, o objeto exige conhecimentos e observadores transdisciplinares.

Aplicados ao processo ensino-aprendizagem, os princípios hologramático e transdisciplinar tornam o aprender uma atividade prazerosa à medida que contextualiza o saber e resgata o sentido do conhecimento (perdido em razão de sua fragmentação e descontextualização). Transformar o conhecimento 
num ato de afirmação do ser. Esse é o desafio que se coloca na reconstrução da prática pedagógica.

A minha postura transdisciplinar me induziu a reunir algumas unidades de significado que se manifestaram ao longo da pesquisa provenientes da multidimensionalidade do ser, nas relações que iam se formando: a escuta, o cuidado, a confiança, a emoção, o empenho, a persistência, a participação, a partilha, a sensibilização, a espiritualidade, a transcendência. A sustentabilidade se incorporando também a essa perspectiva, numa compreensão de sustentabilidade da própria experiência que estava sendo realizada. Todas se entrecruzando a partir do ponto em que cada uma se manifestava, criando uma tessitura transdisciplinar.

O sentimento amoroso construído cotidianamente foi capaz de agregar as diferenças com dialogicidade e resiliência, transversalizado pela natureza integradora de uma abordagem transdisciplinar. Segundo Maturana (2009, p. 23 e 24), é na aceitação do outro, envolto na emoção da vida, que se funda o social. Submerso nesse pensamento, ele diz que "o amor é a emoção que funda o social. Sem a aceitação do outro na convivência, não há fenômeno social". Considerando o pensamento do autor, avalio que mesmo quando sob divergências, os diálogos sempre se fizeram presentes entre nós. Diálogos onde os ruídos foram transformados em harmoniosos acordes de cirandas em círculos, na dança da vida.

Figura 50 - Amor e gratidão

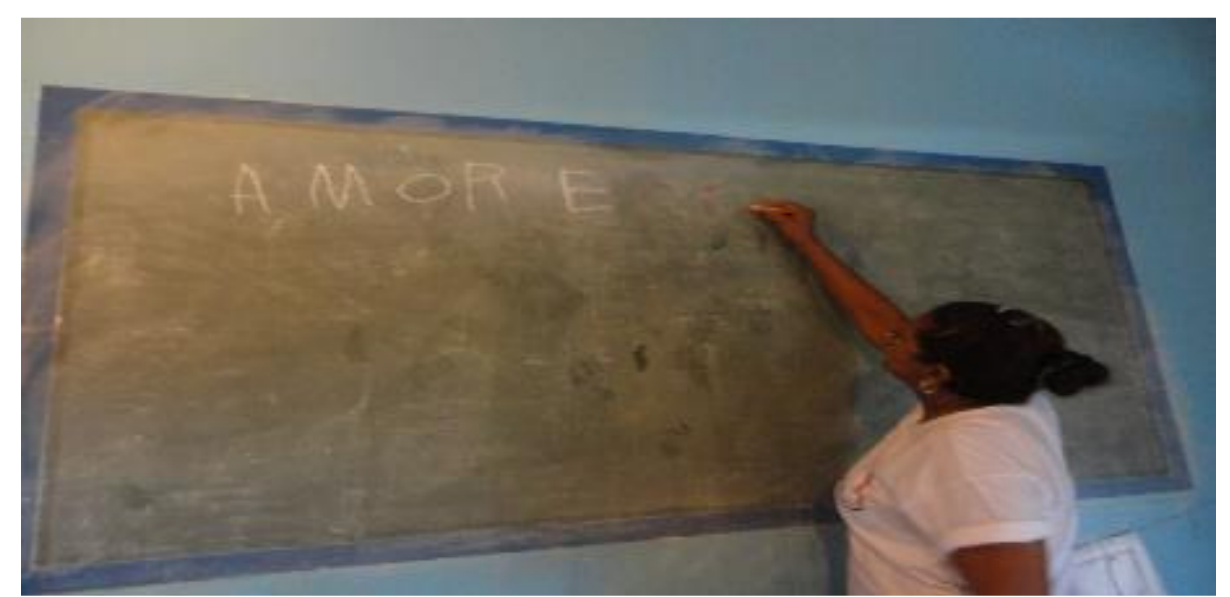

Fonte: Acervo da pesquisa. Dezembro de 2014.

\subsection{Ecos dos ruídos das águas correntes}

Estes ecos são partes dos registros dos depoimentos dos que participaram da experiência. Eles nos contam como foi para cada um a experiência vivida, confirmando a relevância do estudo proposto. 


\section{Sr. Fernando, em entrevista para esta pesquisa:}

Esse trabalho, dessa sua pesquisa e dessa ação que foi feita, nós consideramos como uma ação pioneira aqui em Goiás e foi uma ação que teve um começo um meio e um fim, houve a formação de um grupo de pessoas. E pra nós aqui, enquanto Incubadora e coordenando os projetos, [...] essa foi uma grande dificuldade. Desde 2008, quando nós começamos nossas atividades, que consta nos projetos essa intenção de participar e de promover ações nesse sentido de alfabetização.

Nós encontramos uma dificuldade enorme nesse sentido, primeiro porque as estruturas do processo de alfabetização pra esse caso específico estão muito rígidas [...]. Várias vezes eu procurei a Secretaria de Educação [...]: "ó a estrutura é essa, você me arruma uma turma, traga aqui, tantos dias... [...]". Nós não conseguimos mobilizar porque a situação do catador na cooperativa, do trabalho nas cooperativas, ela é muito característica desse grupo.

E eu quero deixar registrado, primeiro a satisfação que nós tivemos em poder contribuir com esse seu projeto, porque desde o começo eu falei assim: era pra nós da Incubadora algo inalcançável. Até que um dia caiu do céu a Professora Dinorá com esse projeto e que veio justamente atender o que a gente já pensava no início e a dificuldade que nós tínhamos de fazer isso acontecer. E se aconteceu, Dinorá, quero deixar bem registrado, foi pelo seu esforço, seu esforço pessoal, que eu sou testemunha aqui.

\section{Naná, em entrevista para esta pesquisa:}

Ah, todo mundo fala assim: "essa aí que dava aula lá, com a Dinorá". Isso. Eu acho bom. Foi bom. Perguntam se não vai ter de novo, quando que vai ter... Algumas pessoas perguntam.

\section{Maria S, em roda de conversa:}

É que nem eu falei. Cada dia a gente aprende uma coisa diferente, aprende. Com você, com a Jane, né, que também está aqui conosco, ensinando. As artes dela, a gente já aprendeu várias coisas. Sobre a reciclagem que a gente não sabia. Por exemplo, cortar pet pra fazer as coisinhas, as borboletinhas, as florzinhas. A gente não sabia, né. Pintar, desenhar e a gente aprendeu com ela também. Então, cada dia a gente aprende uma coisa diferente. Pra mim está ótimo. Pra mim e pra todo mundo aqui, eu tenho certeza. É uma aula muito agradável. [...] Então eu dizia: já tô velha não aprendo nada, mas a gente aprende né. É vivendo e aprendendo. Já sei ler melhor, escrever melhor.

\section{Maria F, em roda de conversa:}

Foi muito bom. Eu não sabia nem fazer meu nome, agora eu já sei fazer. E tenho muito conhecimento das coisas que você trouxe pra gente aqui. Então eu fiquei muito feliz e agradeço de coração o que você fez e continua fazendo. Vocês também tá certa no 
trabalho que vocês tão fazendo. Eu sou muito grata por isso, por você ter trazido essa aula pra gente. Que eu não sabia de nada. Nada, nada. Hoje eu já sei muita coisa, graças a Deus. Muito entendimento e já sei fazer o meu nome, graças a Deus. E vou aprender muito mais ainda. Minha ararinha. Graças a Deus que se não fosse minha professora que é muito boa, eu não sabia de nada, nada, nada. Que Deus abençoe cada passo dela e de vocês todas.

\section{Seu $F$, em roda de conversa:}

Eu acreditei, agora eu não quis foi vim. Mas depois, eu me arrependi depois, que eu num vim. Se eu tivesse vindo ao menos desde quando eu entrei, tava mais, sabendo mais coisa ainda, mas depois foi caindo na ideia, sabe que eu devia ir? E eu conversando com o C ali, C me disse: Moço, porque você não vai estudar, rapaz? Mas depois ele foi falando, aí caiu a ideia minha. Sabe que eu vô?

\section{Maria P, em roda de conversa:}

Pra mim, eu agora tô achando bom tá olhando pras planta. Porque antes eu olhava mas não ligava não. Agora eu to falando de fazer um jardim bem bonito lá em casa. Fazer uma horta bonita também, lá tem um espaço que dá pra fazer, né. Eu to incutida com isso mesmo, é. É isso mesmo. Aí eu lembro da gente aqui quando a gente tá fazendo a nossa oração. Lembro de respirar, lembro da água também. Eu sei é que eu to muito incutida com isso aí. Eu falei rapaz, tá vendo. Tem coisa que tem que vim uma pessoa lá de longe mesmo pra ... né? É desse jeito mesmo.

Sobre as águas, sobre as árvores, sobre as plantas, né. Em nossa oração de agradecimento também é bom né. Eu mesmo não esqueço de jeito nenhum. Então, isso aí tudo melhora a vida da gente. É bom pra gente. Se sente melhor, tem mais paciência. Porque quando você faz alguma coisa boa, você ora, você reza, você se sente mais melhor. Então você tem mais paciência. Paciência pra cuidar daquela planta, alguma coisa assim. Paciência com as crianças [os filhos]. Até eles querem fazer o que eu faço. Quando eu tô plantando alguma coisa assim, eles vêm atrás de mim e querem me ajudar. Aí o problema é que eles querem saber também e ninguém larga do meu pé. Não pode achar qualquer coisa que querem plantar junto comigo. Depois da aula aqui eu tô fazendo a minha horta. Lá tem pimentão, tem tomate, tem cebola.

Foi muito bom. Pra mim foi muito bom. Eu gostei muito quando eu soube que ia ter uma sala de aula aqui, né. Então, eu chei muito bom isso porque eu tô aprendendo, né, as coisa, tô aprendendo a ler um pouco que eu não sabia, eu sabia só fazer meu nome mesmo e muito bom, eu gostei muito e muito obrigado por você ter vindo dá aula aqui pra nós. E eu tô muito feliz com isso.

\section{Maria A, em roda de conversa:}

A inteligência tá dentro de nós e nós não sabe, né. 


\section{O Caminho de Volta}

Figura 51 - Caminho de volta

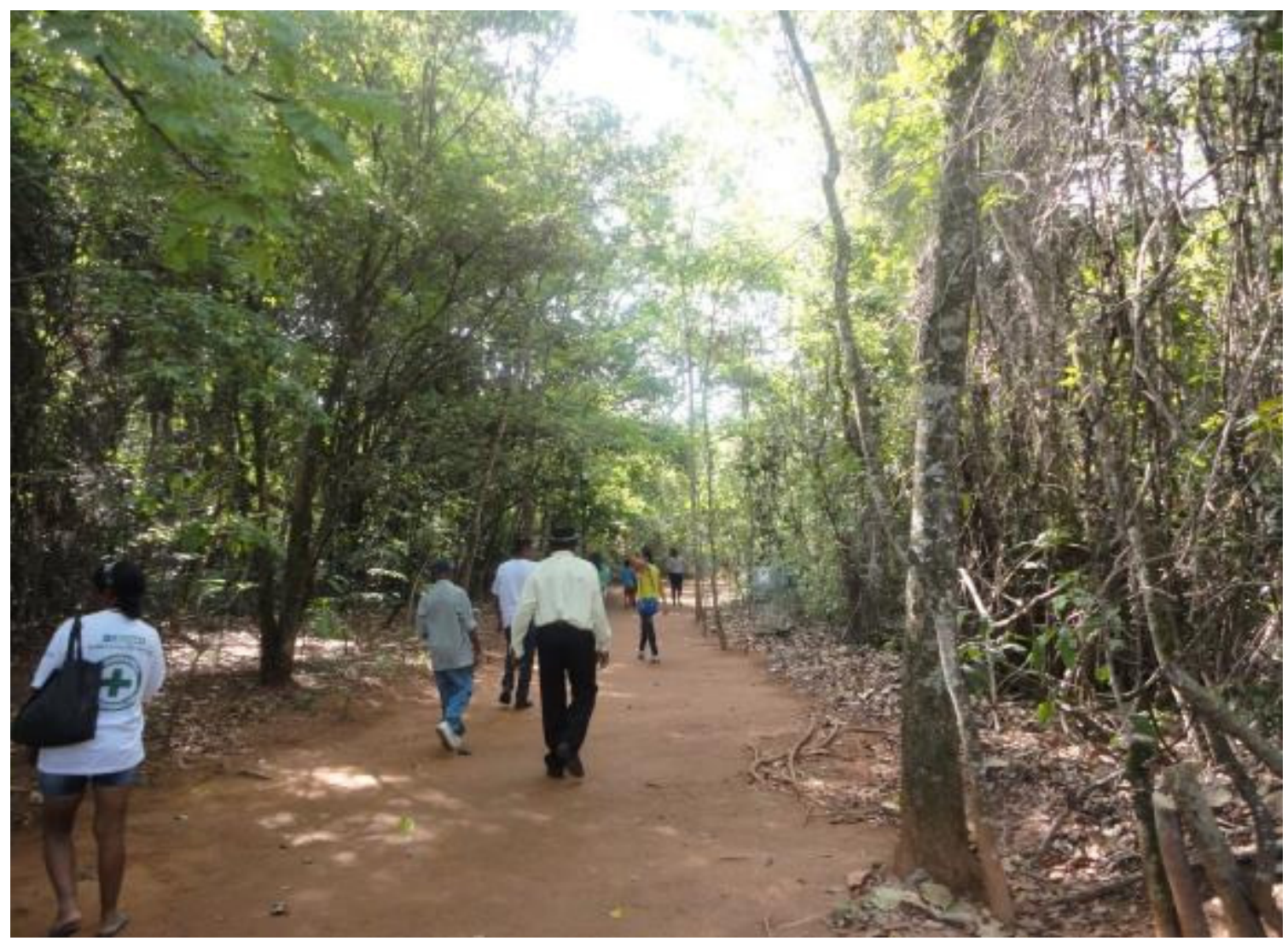

Fonte: Acervo da pesquisa. Memorial do Cerrado. Novembro de 2014. 


\section{CONSIDERAÇÕES:}

o vale das águas movimentadas no caminho

Figura 52 - O vale no Caveirinha

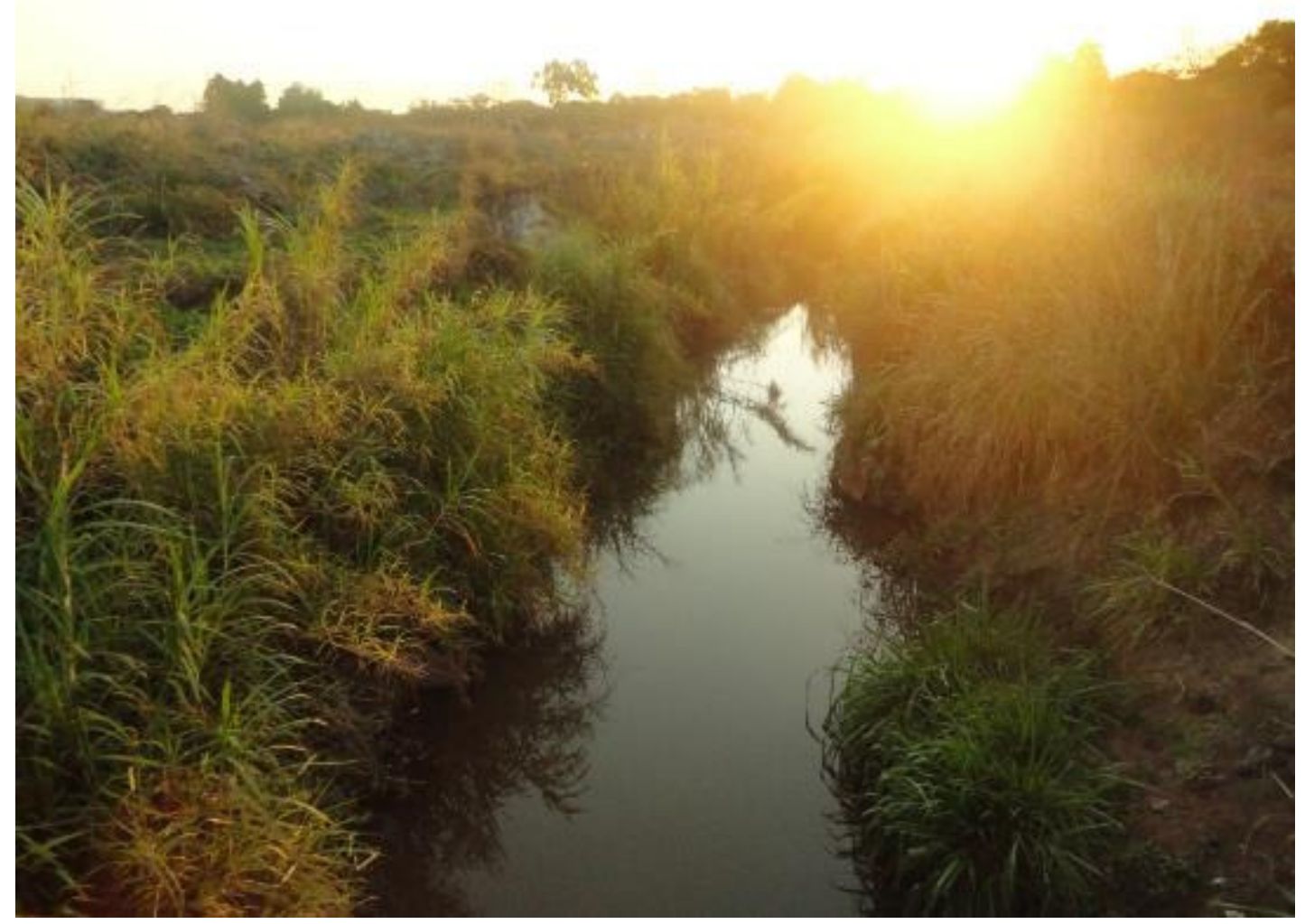

Fonte: Acervo da pesquisa. Córrego Caveirinha. Outubro de 2014. 


\title{
CONSIDERAÇÕES: O VALE DAS ÁGUAS MOVIMENTADAS NO CAMINHO
}

\author{
O homem, \\ quando ele fala que vai fazer uma coisa ele faz, né. \\ Parece que eles quer mandar em Deus. \\ Por isso que Deus muda o tempo dele. \\ Os homem quer mandar em Deus. \\ Se o rio tá lá, foi Deus que deixou ele lá.
}

Maria F

A Educação Ambiental como estratégia de alfabetização de adultos catadores foi a maneira empregada para analisar a contribuição da Educação Ambiental para alfabetização e formação humana junto a uma turma de trabalhadores de uma cooperativa de resíduos sólidos na cidade de Goiânia. Para localizar esses sujeitos percorri 8 cooperativas de catadores vinculadas à Incubadora Social da UFG, em 2013 e 2014, aplicando um questionário para buscar os dados pessoais e escolares desses catadores. Dessa maneira, a comunidade onde a experiência se desenvolveu pôde ser revelada. Assim, a experiência foi desenvolvida, no ano de 2014, em uma comunidade de catadores que vivia no entorno de uma cooperativa de resíduos sólidos, a cooperativa Acop, situada no Setor Albino Boaventura, na Região Noroeste da cidade de Goiânia. Ela revelou, entre os sujeitos envolvidos, a resistência, a baixa autoestima e o distanciamento à vida escolar. Ao mesmo tempo, desvendou o desejo contido, a satisfação de estudar, a alegria por estarem em uma escola deles, inserida naquela comunidade e na realidade de suas vidas. O resgate do ser, do pertencimento e o reconhecimento do valor do catador como um profissional digno e importante para a sociedade urbana atual, foram um caminho para despertar o desejo de aprender a ler e a escrever. Dessa maneira, a alfabetização de adultos trouxe a Educação Popular como campo de diálogo com a EA proporcionando o encontro de elos submersos capazes de originar uma experiência enriquecedora no processo de alfabetização.

A realização da pesquisa levou à constituição de um campo para a efetivação da experiência, ou seja, mesmo comprovando a existência da demanda de adultos catadores que não sabiam ler e escrever, era preciso reuni-los em um lugar onde o processo de alfabetização pudesse ser concretizado. A decisão foi formar uma turma na cooperativa que apresentou maior demanda, assim, a pesquisa pôde se efetivar junto à comunidade da cooperativa Acop. A falta de espaço físico adequado para a instalação de uma sala de aula naquela comunidade foi outra grande dificuldade enfrentada para a formação do campo, evidenciando, também, o distanciamento entre aquela realidade e a da vida escolar. Esse distanciamento é um fato, confirmado também por meio dos dados coletados pelo questionário aplicado, que 
apresentaram 90\% dos catadores fora da escola. Após algum tempo de convivência, percebi que os catadores dessa comunidade, onde está situada a cooperativa Acop, se constituem em um grupo fechado e resistente a aceitar o convite para a alfabetização. Considero que essa atitude é uma forma de proteção adquirida pelo grupo. Talvez pela consciência de classe, adquirida no movimento, mas, mais provavelmente, pelo distanciamento daquela realidade à vida escolar.

Os resíduos sólidos são provenientes do lixo. O lixo é um fenômeno resultante da organização social humana. Somente a humanidade produz lixo, na natureza tudo possui um ciclo e se transforma. A artificialidade da vida criada pela humanidade transforma os recursos naturais em resíduos sólidos e, em nome da sustentabilidade e em prol da vida, estes precisam ser separados do lixo orgânico. Assim, acontece a coleta seletiva, gerando uma nova cadeia no ambiente interno da artificialidade por meio da reciclagem, mas é preciso alertar que somente a reciclagem não basta, muito mais que reciclar é preciso reaproveitar e, principalmente, reduzir, para que seja iniciado um diálogo transformador da relação com a natureza. É, portanto, no reaproveitamento dos produtos, mas, principalmente, na redução do consumo que se inicia o movimento da sustentabilidade. Entretanto, reduzir requer atitudes solidárias, éticas, de justiça, do bem comum. Hoje, não existe nenhuma alternativa para as sociedades que não seja o caminho da sustentabilidade. Uma sociedade que queira, seriamente, orientarse por um desenvolvimento sustentável não pode prescindir de atores sociais críticos e criativos, dispostos ao debate e às ações.

A EP, nascida nos movimentos populares, fortalece o compromisso popular da EA, enquanto a EA, nascida da necessidade de preservação do meio ambiente, fortalece o compromisso da EP com a preservação da vida no planeta Terra. Assim, o desenvolvimento desta pesquisa demonstrou que a opção por um projeto de EA fundido com a EP não se trata simplesmente da escolha de uma temática ambientalista em voga. Bem distante dessa compreensão, demonstra o compromisso na busca de alternativas que possam (cor)responder às questões postas por uma realidade injusta que nos circunda. E a experiência realizada demonstrou que a EA pode acrescentar elementos novos, enriquecedores do caminho que vem sendo trilhado, pois sua atuação se inicia no próprio ser/estar no mundo e se manifesta na maneira de se relacionar, de interagir, faz emergir outros valores humanos, reconhece a centralidade da subjetividade e, desse modo, os sentimentos, a sensibilidade e a espiritualidade são tomados como relevantes para as mudanças que o momento está clamando. Uma mudança de postura diante da vida que provoca a religação das dimensões biológicas e antropossociais e ressignifica a relação entre natureza e cultura. 
O que pude notar, ao longo da pesquisa, é que existe muita dificuldade para integrar os princípios holísticos da EA. Essa dificuldade não reside em resistências vazias, por parte de quem trabalha com a educação, mas, principalmente, no desconhecimento da EA como um campo que tem uma concepção e princípios próprios, localizado em uma zona de não resistência onde, segundo Nicolescu (2000), o "Conhecimento não é nem exterior nem interior: ele é simultaneamente exterior e interior." Portanto, capaz de incorporar e ser incorporado simultaneamente às práticas didático-pedagógicas. Uma demanda que implica em formação para que a EA não seja compreendida como uma temática, mas incorporada ao trabalho educacional escolar, transversalizando princípios e concepções e, em decorrência, toda a prática desenvolvida, resgatando a alma da educação e fazendo com que a EA não seja mais vista com estranhamento. Ainda hoje, não raro, entendem a EA como alienação e distanciamento das lutas sociais, mas, bem diferente disso, a experiência que eu vivi junto a essa comunidade me fez ver com clareza que foi pelo meu embasamento nos princípios multirreferenciais, multidimensionais e transdisciplinares da EA que me fortaleceu para o alcance dos propósitos lançados. A experiência vivida no campo desta pesquisa acoplou o entendimento de que a educação é a via por meio da qual o homem pode reinventar a vida, aprendendo a ser quando aprende a conhecer, a fazer e a viver juntos.

Fui construindo a minha relação com o grupo em um exercício profundo de compaixão, solidariedade, cooperação. Agindo com humildade, respeito, compreensão, dialogicidade, escuta, resiliência, persistência e conexão amorosa entre os vários níveis de realidade, do macro ao microcosmo, me percebendo parte do mesmo mundo, do mundo dos catadores. Assim, a minha ecologia humana se entrelaçava com a ecologia humana daquela comunidade e dos educandos que compartilharam a experiência de alfabetização. A experiência realizada com os catadores indica que as estratégias da Educação Ambiental podem fazer diferença ao serem integradas à alfabetização de adultos, com toda a demanda de situações específicas que brotam dessa realidade.

Falar a respeito da Educação Ambiental (EA) é falar da essência de nossa existência. Pois a EA passa pela ampliação da percepção de nosso estar no mundo religando a vida humana à vida da natureza. A EA faz as inter-conecções entre as partes que constituem o todo, podendo cada parte constituir-se também em um todo. Essa perspectiva, que é a base do princípio hologramático de Morin, nos remete ao entendimento do compromisso da EA. Assim, busquei um entendimento acerca da EA e da EP, a fim de fortalecer as relações entre esses campos, visto que a compreensão de uma EA crítica considera a EA pra além do cuidado da natureza, perpassando pelo cuidar de si, do outro, da sociedade e da natureza. Um 
movimento ininterrupto amalgamado pela vida. Nesse percurso, a história e os princípios da EA e da EP, apresentados na pesquisa realizada, demonstraram o contexto que lhes deu origem, o compromisso social e a relevância da junção desses campos para a transformação da conjuntura social política, econômica, cultural e ecológica atual. Por esse caminho, pude verificar que a percepção social crítica, aliada à ampliação da tomada de consciência ambiental, está na base dos compromissos que transitam no espaço cultivado entre a EA e a EP.

A natureza nos mostra que tudo está conectado a tudo. Assim, são muitos os elos que se interconectam, interconectando todas as manifestações de vida, formando uma cadeia que se nutre da cooperação, da solidariedade, do amor. A EA e a EP, compromissadas com a construção de um mundo mais justo, mais humanizado e sustentável, se conectam às forças que nutrem as fontes da vida. A percepção de que na natureza tudo está interligado e interconectado é a fonte que origina o pertencimento, alimentada pela formação humana emancipatória, que se realiza por uma aprendizagem significativa.

Como demarcar limites para campos que se constituem na complexidade da mesma realidade social? Aumento da violência no centro e nas periferias urbanas, assaltos, roubos, criminalidades, milícias, drogas. Que valores, que educação, que sociedade, que modelo de democracia e participação? Que relação estabelecer com a biodiversidade e com o meio ambiente? A história da humanidade sempre esteve inserida na natureza, mas parece que o homem nunca soube se relacionar harmoniosamente com a natureza e com isto perdeu a coerência da relação consigo próprio. A junção desses dois campos fortalece a alfabetização de adultos e, ao mesmo tempo, as dimensões abrangidas pela ação de uma educação transformadora, capaz de confrontar-se com a exploração capitalista, devastadora do homem e da natureza. Já houve épocas em que a natureza era mais poderosa que o homem, hoje a nossa "Mãe Terra" precisa de ajuda para manter a vida no planeta.

O encerramento das atividades da turma foi marcado pela emoção dos educandos e minha também. A sala estava cheia e eles demonstraram o desejo de poder continuar estudando. Ao final das atividades, todos estavam conseguindo escrever o nome e Maria $\mathrm{P}$ conseguindo ler e escrever. Em 2015, cheguei a reunir-me com um grupo e a conseguir uma educadora popular para organizar uma turma, mas o AJA-Expansão não fez formação, justificou que o Programa Brasil Alfabetizado (PBA) não liberou o financiamento. Em 2016, houve uma tentativa de formar nova turma, mas as dificuldades surgiram e não houve força suficiente para superá-las. 
A experiência realizada nesta pesquisa, com o grupo dos catadores, criou vínculos e, ao final, despertou o desejo de que a turma não fosse encerrada. Esse desejo de dar continuidade ao trabalho iniciado indica o círculo de cultura como um tipo de atendimento que pode dar um acolhimento mais aproximado à realidade daquele grupo, uma estrutura que seja aberta, flexível, autônoma, agregadora, capaz de contemplar a aspiração do grupo. Esse tipo de atendimento favorecido pelos Círculos de Cultura é uma alternativa a ser considerada para suscitar uma aprendizagem significativa que corresponda às necessidades daquela comunidade. Uma alternativa que se apresenta com possibilidade de dar continuidade aos encontros daquele grupo, correspondendo aos seus desejos, abrindo infinitas maneiras de partilhas, trocas, aprendizagens, conhecimentos, criatividade, articulações, intervenções, realizações e sonhos.

As pessoas da comunidade da Acop possuíam uma relação solidária e de cuidado entre elas, o grupo era fechado e compartilhava internamente um clima de confiança e partilha. Por isso, entendo que a ideia de círculo de cultura pode ser uma alternativa para que o grupo continue se encontrando e dando prosseguimento ao processo de aprendizado da leitura e escrita. Um lugar para conversar, cantar, tocar um instrumento, meditar, contemplar, orar, produzir cultura e encantamento, tematizando discussões, produzindo arte, reconectando universos. Entendo que como órgão vinculado a uma universidade federal, a Incubadora Social da UFG pode ampliar o seu atendimento às cooperativas que a ela estão vinculadas, fornecendo, além da orientação de gestão, também uma formação e acompanhamento didático-pedagógico por meio de um projeto específico multirreferencial, construído coletivamente, atendido por estudantes bolsistas acadêmicos, envolvendo as várias áreas da ciência, abrindo um amplo campo de pesquisa e proporcionando um espaço de manifestação de cultura em cada cooperativa.

O sentimento que me envolve agora, em relação a todo este estudo realizado, é o de perceber a presença de um vale amoroso, acolhedor, capaz de receber todas as águas das fontes movimentadas. Esse sentimento vai ao encontro do que está expresso por Morin (2008, p.39) quando diz da necessidade que o estimulou a empreender a sua pesquisa. "Eu me senti ligado ao patrimônio planetário, animado pela religião daquilo que reúne, a rejeição daquilo que rejeita, uma solidariedade infinita; o que Tao chama de Espírito do vale "recebe todas as águas que derramam nele"." (Grifos do autor) Esse sentimento foi o que me transportou para a terceira margem, pois ao longo do estudo fui me dando conta de que a travessia, inicialmente percebida como sendo o deslocar de uma margem a outra, se revelou como sendo uma travessia de diferentes dimensões, em uma zona de não resistência, do macro ao microcosmo, 
em diferentes níveis da existência humana, na conexão com o todo, percorrendo os caminhos de dentro para alcançar os caminhos da vida na relação entre todos os seres. Em meu diário de campo, encontrei esta anotação do dia 07/06/2014, que confirma esse sentimento:

(20) Os caminhos tortuosos inventados pelas águas, na necessidade incontível de ir, não são uma escolha, mas o movimento possível para a garantia do fluxo. Preciso aprender os ensinamentos da água. As situações que tenho enfrentado têm me mostrado isso. Têm me conduzido a ver que as tessituras da vida se entrelaçam a tantas vidas de diferentes niveis e distintas dimensões, todas seguindo o fluxo contínuo e incontivel das águas que as alimentam.

O que percebi, então, a partir da pesquisa realizada, é que, embora apareçam como dois campos distintos, a EA e a EP estão fundidas no encontro das águas profundas que envolvem esses sujeitos. Nessas águas, os conflitos, as hierarquias, as disputas perdem suas forças, dando lugar para o entendimento, a cooperação, a vida, quando a disputa é pela sobrevivência. Pela experiência vivida no campo desta pesquisa, de alfabetização de adultos catadores, percebi que a condição de vida desses sujeitos os torna mensageiros de uma cultura e de um viver que partem da realidade dura da vida, que se funde com os campos floridos dos sonhos, sustentados pela natureza da existência e se projetando nas arenas das ciências.

A Educação Ambiental na alfabetização e formação humana de trabalhadores de cooperativa de resíduos sólidos se efetiva por meio de estratégias ecopedagógicas, que contribuem para uma aprendizagem significativa, desenvolvendo a sensibilidade humana e fortalecendo o pertencimento. A experiência vivida proporcionou transformações a partir da ampliação da percepção de si na interação afetuosa com a água, o ar, as plantas e com os outros seres, na relação com o meio ambiente. Deste modo, ressalta-se a importância da contribuição da EA para a efetivação de uma educação transformadora, fortalecendo os princípios da EP. Elos de compromisso para mudanças sociais que alimentem a vida no Planeta Terra. 


\section{REFERÊNCIAS BIBLIOGRÁFICAS: FONTES ACOPLADAS}

ARENDT, Hannah. A condição humana. 10 ed. Rio de Janeiro: Forense Universitária, 2008.

BAIANO, Hélverton. Paraíso Profano. Goiânia: Lei Goyazes, 2008.

BARBIER, René. Abordagem transversal. Tradução de Rogério Córdova do original francês "L'approche Transversale: L'écoute sensible em sciences humaines". Paris: Anthropos, 1997.

A Pesquisa-Ação. Brasília: Liber Livro Editora, 2007.

BARBOSA, Altair Sales et. al. O Piar da Juriti Pepena: narrativa ecológica da ocupação humana do cerrado. Goiânia: Ed. da PUC Goiás, 2014.

BIANO, Janiere Rodrigues Rosa. Palavras de Marias e João - experimentações com materiais reutilizáveis no ensino de arte. Trabalho de Conclusão de Curso (TCC), Faculdade de Artes Visuais (FAVE), Universidade Federal de Goiás, Goiânia, 2014.

BRANDÃO, Carlos Rodrigues; ROCHA, Evandra. O jardim da vida. Goiânia: Ed. da UCG, 2004.

BRANDÃO, Carlos Rodrigues. Aqui é onde eu moro, aqui nós vivemos: escritos para conhecer, pensar e praticar o Município Educador sustentável. 2 ed. Brasília: MMA, Programa Nacional de Educação Ambiental, 2005.

A pesquisa participante e a participação da pesquisa. In: BRANDÃO, Carlos

Rodrigues e STRECK, Danilo Romeu. Pesquisa participante: o saber da partilha. 2 ed. São Paulo: Ideias \& Letras, 2006.

. A educação popular e a educação de jovens e adultos: antes e agora. In: MACHADO, Maria Margarida. Formação de educadores de jovens e adultos. Brasília, Secad/MEC, UNESCO, 2008.

"La educacion popular es um gran paraguas". Entrevista concedida ao jornal "Página 12". Buenos Aires, janeiro de 2014.

BRASIL. Política Nacional de Resíduos Sólidos. Lei nº 12.305, de 2 de agosto de 2010.

BRASIL. Marco da Ação de Belém. Organização das Nações Unidas para a Educação, a Ciência e a Cultura (UNESCO) e Ministério da Educação. Brasília, 2010.

BRASIL. Marco De Referência Da Educação Popular Para As Políticas Públicas.

Secretaria Geral da Presidência da República, Secretaria Nacional de Articulação Social, Departamento de Educação Popular e Mobilização Cidadã. 2014.

BRUNDTLAND, Gro Hardem. Comissão Mundial Sobre Meio Ambiente e Desenvolvimento. Nosso futuro comum. $2^{\text {a }}$ Ed., Rio de janeiro: Fundação Getúlio Vargas, CMMAD, 1991.

CAPRA, Fritjof. A teia da vida: uma nova compreensão científica dos sistemas vivos. São Paulo: Cultrix, 1996. 
CANESIN, Maria Tereza. A fertilidade da produção sociológica de Bourdieu para ciências sociais e educação. In: ROSA, Dalva E. Gonçalves; SOUSA, Vanilton Camilo de (Orgs).

Didática e práticas de ensino: interfaces com diferentes saberes e lugares formativos. Rio de Janeiro: DP\&A, 2002.

CARVALHO, Isabel Cristina de M. Educação Ambiental: a formação do sujeito ecológico. São Paulo: Cortez, 2011.

CATALÃO, Vera M. Lessa. A redescoberta do pertencimento à natureza por uma cultura da corporeidade. Terceiro incluído - ISSN 2237-079X - NUPEAT-IESA-UFG, v.1, n.2, jul./dez./2011, p.74-81, Artigo 12.

Educação ambiental e escola - retorno ao naturalismo ou senha para a transformação?. Mestrado em Educação. Universidade de Brasília. Brasília, 1993.

Desenvolvimento sustentável e Educação Ambiental no Brasil. In: PÁDUA, José Augusto. Desenvolvimento, justiça e meio ambiente. São Paulo: Peirópolis, UFMG, 2009.

CATAlÃo, Vera M. Lessa; RODRIGUES, Maria do Socorro (Org.). Água como Matriz Ecopedagógica. Brasília: Edição do Autor, 2006.

CLÍMACO, Arlene Carvalho de A. Clientelismo e cidadania na constituição de uma rede pública de ensino. In: SILVA, Aurora H. F.; EVANGELISTA, Ely S. Caminhando e abrindo caminhos: trajetória de uma rede municipal de educação. Goiânia, Editora UFG, 2004.

COSTA, Cláudia Borges. O trabalhador-aluno da EAJA: desafios no processo ensinoaprendizagem. Mestrado em Educação. Pontifícia Universidade Católica de Goiás. Goiânia, 2008.

CORA CORALINA. Das Pedras. In.: DENÓFRIO, Darcy França. Cora Coralina: seleção. Coleção Melhores Poemas. São Paulo: Global, 2004.

CUNHA, Alda Maria Borges; RODRIGUES, Maria Emilia de C; MACHADO, Maria Margarida. Alfabetização de Jovens e Adultos: política pública e movimento popular. Cad. Cedes, vol. 27, n.71, p. 19-38, jan./abr. Campinas, 2007.

CZAPSKI, S. A implantação da educação ambiental no Brasil. Brasília: Ministério da Educação e do Desporto, Coordenação de Educação Ambiental, 1998.

DANSA, Cláudia; PATO, Claudia; CORRÊA, Rosângela. Educação Ambiental e Ecologia Humana: Contribuições para um Debate. In.: MARQUES, Juracy (Org.). Ecologias

Humanas. 1 ed. Feira de Santana: UEFS, 2014.

DE BECKER, Geneviève. Enciclopédia da natureza. Tradução de Regina Célia de Oliveira. Barueri, SP: Girassol; Bélgica: Éditions Caramel, 2008.

DIAS, Genebaldo Freire. Educação Ambiental: princípios e práticas. 8 ed. São Paulo, Gaia, 2003.

FIORAVANTI, Celina. Mandalas: Como Usar a Energia dos Desenhos Sagrados. São Paulo, Pensamento, 2003. 
FONSECA, Mônica Maria Lopes; ECHEVERRÍA, Agustina Rosa. Práticas de educação ambiental de um grupo de professores do município de Goiânia: conhecer para avançar. In: SILVA, Aurora H. F. e EVANGELISTA, Ely S. Caminhando e abrindo caminhos: trajetória de uma rede municipal de educação. Goiânia, Editora UFG, 2004.

FRANCO, Maria Laura P. B. Análise de Conteúdo. 4 ed. Brasília: Liber Livro, 2012.

FRANTZ, Walter. Associativismo, cooperativismo e economia solidária. Ijuí: Ed. Unijuí, 2012. (Coleção educação à distância. Série livro-texto).

FREIRE, Paulo. A importância do ato de ler. 50 ed. São Paulo: Cortez, 2009.

Conscientização: teoria e prática da libertação: uma introdução ao pensamento de Paulo Freire / Paulo Freire. Tradução de Kátia de Mello e Silva; revisão técnica de Benedito Eliseu Leite Cintra. - São Paulo: Cortez \& Moraes, 1979a.

Criando Métodos de Pesquisa Alternativa: aprendendo a fazê-la melhor através da ação. In: BRANDÃO, C. Rodrigues (Org.). Pesquisa Participante. São Paulo: Editora Brasiliense, 1981.

Educação e mudança. 28 ed. Rio de Janeiro: Paz e Terra, 1979.

Pedagogia do Oprimido. Rio de Janeiro: Paz e Terra, 1987.

Pedagogia da autonomia: saberes necessários à prática educativa. 33 ed. São Paulo: Paz e Terra, 2006.

FREIRE, Paulo. FREIRE, Ana Maria de Araújo. À sombra desta mangueira. - 11 ed. - Rio de Janeiro: Paz e Terra, 2013.

GADOTTI, Moacir. Pedagogia da Terra. Capítulo de livro. In: Paulo Freire y la agenda de la educación latinoamericana en el siglo XXI. CLACSO, Conselho Latino-americano de Ciências Sociais. Buenos Aires, 2001.

GALHARDO, Irma. Pai do Mato. Palmas: Irma C. S. Galhardo, 2012.

GAUDIANO, Edgar Gonzalez. Educação Ambiental. Instituto Piaget. Lisboa: Horizontes Pedagógicos, 2005.

GOIÂNIA. Secretaria Municipal de Educação. Orientações preliminares sobre a nova estrutura da educação de adolescentes, jovens e adultos para 2016. Goiânia, 2016.

GOIÂNIA. Secretaria Municipal de Educação. Avaliação da educação de jovens e adultos no plano municipal de educação de Goiânia 2004-2014. Goiânia, 2015.

GOIÂNIA. Secretaria Municipal de Educação. Proposta Político-Pedagógica para a Educação de Adolescentes, Jovens e Adultos, da Rede Municipal de Educação de Goiânia. Goiânia, 2013. 
GOIÂNIA. Secretaria Municipal de Educação. Proposta Político-Pedagógica para a Educação de Adolescentes, Jovens e Adultos, da Rede Municipal de Educação de Goiânia. Goiânia, 2010.

GOIÂNIA. Programa Goiânia Coleta Seletiva (PGCS). Companhia de Urbanização de Goiânia (COMURG), 2008. Disponível em:

$<$ https://www.goiania.go.gov.br/shtml/coletaseletiva/principal.shtml>. Acesso em: 2 abr. 2014.

GOIÂNIA. Secretaria Municipal de Educação. Ações e Concepções 2001-2004. Goiânia, 2002.

GOIÂNIA. Secretaria Municipal de Educação. PROJETO AJA - A Educação fazendo sua parte. Prioridade de Governo, Gestão 2001/2004. Goiânia, 2001.

GOMES, Dinorá de Castro. A "Escola Municipal Flor do Cerrado": uma experiência de educação de adolescentes jovens e adultos em Goiânia. Mestrado em Educação. Pontifícia Universidade Católica de Goiás. Goiânia, 2006.

GRÜN, Mauro. Em busca da dimensão ética da educação ambiental. Campinas, SP: Papirus, 2007.

GUTIÉRREZ, Francisco e PRADO, Cruz. Ecopedagogia e Cidadania Planetária. $2^{\mathrm{a}}$ ed. São Paulo: Cortez, 2000.

KROPOTKIN, Piotr. Ajuda Mútua: um fator de evolução. Tradução Waldyr Azevedo Jr. São Sebastião: A Senhora Editora, 2009.

LEAR, Linda. Introdução. In: CARSON, Rachel. Primavera Silenciosa. I ed., São Paulo: Gaia, 2010.

LEFF, Enrique. Discursos sustentáveis. São Paulo: Cortez, 2010.

LIBÂNEO, José Carlos; OLIVEIRA, João Ferreira de; TOSCHI, Mirza Seabra. Educação escolar: políticas, estrutura e organização. São Paulo: Cortez, 2003. (Col. Docência em formação).

LIMA, Ma Isabel R. Economia Solidária e Vínculos. São Paulo: Ideias e Letras, 2013.

LOUREIRO, Carlos Frederico B. Complexidade e dialética: por uma busca de novos elementos na tradição crítica diante dos desafios da educação ambiental. In: Ambiente e Educação, Revista de Educação Ambiental da FURG, Vol 12. Rio Grande, 2007.

Educação Ambiental e “Teorias Críticas”. In: GUIMARÃES, Mauro (org.).

Caminhos da Educação Ambiental: da forma a ação. 5 ed. Campinas, SP, Papirus, 2013 (Coleção Papirus Educação)

LUDKE, Menga; ANDRÉ, Marli E. D. A. Pesquisa em Educação: Abordagens Qualitativas. São Paulo: EPU, 1986 - (Temas básicos de Educação e Ensino).

MACEDO, Roberto Sidnei. A Etnopesquisa Implicada: Pertencimento, criação de saberes e afirmação. Brasília: Liber Livros, 2012. 
MACHADO, Maria Margarida, et al. "Política de Educação de Jovens e Adultos em Goiânia$G O$ ”. In: HADDAD, Sérgio. (Org.). Novos Caminhos em Educação de Jovens e Adultos EJA. Um estudo de ações do poder público em cidades de regiões metropolitanas brasileiras. Fapesp, Ação Educativa, São Paulo, 2007.

MACHADO, Maria Margarida. Política Educacional para Jovens e adultos: a experiência do Projeto AJA (1993-1996) na Secretaria municipal da Educação de Goiânia. In: SILVA, Aurora H. F. e EVANGELISTA, Ely S. Caminhando e abrindo caminhos: trajetória de uma rede municipal de educação. Editora UFG, Goiânia, 2004.

MACHADO, Maria Margarida. Política Educacional para Jovens e Adultos: a experiência do projeto Aja (96/96) na Secretaria Municipal de Educação. Dissertação (Mestrado em Educação Brasileira), Faculdade de Educação, Universidade Federal de Goiás (UFG). Goiânia, 1997.

MATURANA, Humberto R.; VARELA, Francisco J. A árvore do conhecimento: as bases biológicas da compreensão humana. Tradução: MARIOTTI Humberto; DISKIN, Lia. São Paulo, Palas Athena, 2001.

MATURANA, Humberto R. Emoções e linguagem na educação e na política. Tradução: FORTES, José Fernando Campos. 1ed. atualizada. Belo Horizonte: Editora UFMG, 2009.

MINAYO, Maria Cecília de Sousa. Ciência, técnica e arte: o desafio da pesquisa social. In: Pesquisa Social: teoria, método e criatividade. MINAYO, Maria Cecília de Sousa (Org.). 21 ed. Petrópolis, RJ: Vozes, 1994.

MOREIRA, Antônio Flávio Barbosa; CANDAU, Vera Maria. Currículo, Conhecimento e Cultura. 2007. Disponível em:

<http://portal.mec.gov.br/seb/arquivo/pdf/Ensfund/indag3.pdf.> Acesso em: 19 nov. 2008.

MORIN, Edgar. Os sete saberes necessários à educação do futuro. 8 ed.-São Paulo: Cortez; Brasília, DF: UNESCO, 2003.

. O Método Vol. I - A Natureza da Natureza. 2a ed. Porto Alegre: Sulina, 2008.

O Método Vol. II - A Vida da Vida. 4ª ed. Porto Alegre: Sulina, 2011.

Introdução ao pensamento complexo. $5^{\text {a }}$ Ed. Porto Alegre: Sulina, 2015.

MUNARIM, Antonio. Parceria: uma faca de muitos gumes. In: Construção Coletiva: contribuições à educação de jovens e adultos. - Brasília: UNESCO, MEC, RAAAB; Ministério da Educação: Coleção educação para todos; Brasil, 2005.

NASCIMENTO, Milton. Nos Bailes da Vida. In: NASCIMENTO, Milton. Tambores de Minas. CD. Manaus: Warner Music Brasil Ltda, 1998.

NEVES, Virgílio de Castro. Os Estados Unidos e o Protocolo de Kyoto: Consciência Ambiental ou Perda de Hegemonia? Trabalho de Conclusão de Curso (TCC). Relações Internacionais. Pontifícia Universidade Católica de Goiás (PUC-Goiás). Goiânia, 2009.

NICOLESCU, Basarab. O manifesto da transdisciplinaridade. Tradução Lúcia Pereira de Souza. São Paulo: TRIOM, 1999. 
Um novo tipo de conhecimento - transdisciplinaridade e A prática da

transdisciplinaridade. In: Educação e Transdisciplinaridade. Brasília: UNESCO, 2000.

NOAL, Fernando Oliveira. Josué de Castro: origens de uma pedagogia socioambiental brasileira. In: NOAL, Fernando Oliveira; BARCELOS, Valdo Hermes de Lima. (Orgs). Educação Ambiental e Cidadania: cenários brasileiros. Santa Cruz do Sul: EDUNISC, 2003.

OLIVEIRA, Inês Barbosa; PAIVA, Jane. Educação de jovens e adultos. Rio de Janeiro: DP\&A, 2004.

OLIVEIRA, Marta Khol. Jovens e adultos como sujeitos de conhecimento e aprendizagem. In: Revista Brasileira de Educação, nº 12. São Paulo: dezembro, 1999.

RIBEIRO, Sérgio; CATALÃO, Vera; FONTELES, Bené. Água e cooperação: reflexões, experiências e alianças em favor da vida. Brasília: Ararazul, Organização para a Paz Mundial, 2014.

RIBEIRO, Sérgio. A transdisciplinaridade como caminho para a cooperação para a água. In: RIBEIRO, Sérgio; CATALÃO, Vera; FONTELES, Bené. Água e cooperação: reflexões, experiências e alianças em favor da vida. Brasília: Ararazul, Organização para a Paz Mundial, 2014.

RODRIGUES, Maria Emília de Castro. A prática do professor na educação de adolescentes, jovens e adultos: a experiência do Projeto Aja de Goiânia, GO. In: SILVA, Aurora H. F.; EVANGELISTA, Ely S. Caminhando e abrindo caminhos: trajetória de uma rede municipal de educação. Goiânia, Editora UFG, 2004.

. A Prática do Professor na Educação de Adolescentes, Jovens e Adultos: A experiência do Projeto AJA de Goiânia-GO. Dissertação (Mestrado em Educação Brasileira), Faculdade de Educação, Universidade Federal de Goiás. Goiânia, 2000.

Educação de jovens e adultos: retomando uma história negada (uso didático restrito). Mimeo, 2011.

SÁ, Laís Mourão. Pertencimento. In: Ministério do Meio Ambiente, Diretoria de Educação Ambiental. Encontros e Caminhos: Formação de Educadoras(es) Ambientais e Coletivos Educadores. Brasília - DF, 2005.

SANTOS, Akiko. Complexidade e transdisciplinaridade em educação: cinco princípios para resgatar o elo perdido. In: SANTOS, Akiko; SOMMERMAN, Américo (Orgs)

Complexidade e transdisciplinaridade: em busca da totalidade perdida. Porto Alegre:

Sulina, 2009.

SANTOS, Esmeraldina Maria dos. "Os saberes dos professores do Ensino Fundamental da Educação de Jovens e Adultos". Dissertação, Mestrado em Educação. Pontifícia Universidade Católica de Goiás. PUC-GO. Goiânia, 2007.

SAUVÉ, Lucie. Uma cartografia das correntes em educação ambiental. In: SATO, Michèle; CARVALHO, Isabel. Educação Ambiental: pesquisa e desafios. Porto Alegre: Artmed, 2005. 
SATO, Michèle; PASSOS, Luiz Augusto. Pelo prazer fenomenológico de um não texto. In: GUIMARÃES, Mauro (Org.). Caminhos da Educação Ambiental: da forma à ação. 5 ed. Campinas, Papirus, 2013. (Coleção Papirus Educação)

SATO, Michèle. Debatendo os desafios da educação ambiental. In: I Congresso de Educação Ambiental Pró Mar de Dentro. Rio Grande: Mestrado em Educação Ambiental, FURG \& Pró Mar de Dentro, 17-21/maio/2001.

SCHWENK, T. Le chaos sensible: creation de forms par les moviment de L'eau et de l'air. Paris: Editions Triades, 1982.

SILVA, Ivonete Maria da. Ou trabalha e come ou fica com fome e estuda. Dissertação (Mestrado em Educação Brasileira) Faculdade de Educação da Universidade Federal de Goiás. Goiânia, 2004.

SILVA, Tomaz Tadeu da. Documentos de Identidade: Uma introdução às teorias do currículo. Belo Horizonte, Autêntica, 2003.

SINGER, Paul. Prefácio. In: LIMA, Ma Isabel R. Economia Solidária e Vínculos. São Paulo: Ideias e Letras, 2013.

Introdução à economia solidária. $1^{\mathrm{a}}$ ed. São Paulo: Editora Fundação Perseu Abramo, 2002.

SOARES, Magda. Alfabetização: a ressignificação do conceito. In.: Construção Coletiva: contribuições à educação de jovens e adultos. - Brasília: UNESCO, MEC, RAAAB; Ministério da Educação: Coleção educação para todos; Brasil, 2005.

TASSARA, Eda T. O.; TASSARA, Helena; ARDANS, Hector Omar. Empoderamento (versus Empoderar-se). In.: FERRARO JUNIOR, L. A. (Org.). : Encontros e Caminhos: Formação de educadoras(es) Ambientais e Coletivos Educadores - Volume 3. Brasília: MMA/DEA, 2014.

TRATADO de educação ambiental para sociedades sustentáveis e responsabilidade global. In: $1^{\circ}$ Jornada de Educação Ambiental -Rio 92. Rio de Janeiro, 1992. Disponível em: $<$ http://portal.mec.gov.br/secad/arquivos/pdf/educacaoambiental/tratado.pdf $>$. Acesso em: 2 abr. 2014.

VYGOTSKY, L. S. Pensamento e Linguagem. São Paulo: Martins Fontes, 1998.

ZANETI, Izabel Cristina Bruno Bacellar. As sobras da modernidade: O sistema de gestão de resíduos sólidos em Porto Alegre, RS. Porto Alegre - RS: FAMURS, 2006.

\section{VÍDEOS}

ICOLOGIA. Produção de Ângelo Lima. Goiânia: Pinnacle Produções. 2004. 1 DVD.

CATADOR DE SONHOS. Produção de Giovani Lorenzetti. Goiânia: Belcar Caminhões. 2007. 1 DVD. 


\section{APÊNDICE A - DADOS PESSOAIS E ESCOLARES DOS COOPERADOS}

\begin{tabular}{|l|l|l|}
\hline & $\begin{array}{l}\text { Universidade de Brasília / Faculdade de Educação / PPGE } \\
\text { Linha de pesquisa: Educação Ambiental e Educação do Campo } \\
\text { Orientadora: Professora Dra Vera Margarida Lessa Catalão } \\
\text { Orientanda: Doutoranda Dinorá de Castro Gomes } \\
\text { Matrícula: } 120047438\end{array}$ & $\begin{array}{l}\text { INCUBADORA SOCIAL } \\
\text { PR O E C }\end{array}$ \\
\hline
\end{tabular}

Cooperativas de resíduos sólidos na cidade de Goiânia - GO Dados Pessoais e Escolares dos Cooperados

Nome da Cooperativa:

Endereço:

Data: 1

\section{Informações Pessoais}

Nome do cooperado:

Sexo: ( ) Masculino ( ) Feminino Data de nascimento: I

Estado Civil:

( )Casado ( )Separado ( )Vive com companheiro (a) ( )Viúvo ( ) Solteiro Tem filhos? ( )Sim ( )Não Quantos? Nacionalidade: Naturalidade: Idade dos filhos:

Endereço: Telefone:

Cor - Raça:

( )Branca ( )Preta ( )Parda ( )Amarela ( )Indígena ( )Prefiro não identificar Documentos pessoais que possui:

( ) Carteira de Identidade - RG ( )Certidão de Nascimento ( ) Carteira de Trabalho

( )Certidão de Casamento ( )CPF ( )Título de Eleitor ( )Recadastro Biométrico

( )Nenhum

Tem alguma deficiência? ( )Sim ( )Não Qual?

Como se transporta para a cooperativa: 
( )a pé ( )de transporte público ( )de motocicleta ( )de bicicleta ( )de carro ( )outros

Além da atividade que desenvolve na cooperativa, que outras habilidades artísticas ou profissionais possui?

Qual a sua renda mensal?

( )até 1 salário mínimo ( )de 1 a 3 salários mínimos ( )de 3 a 5 salários mínimos

( ) acima de 5 salários mínimos

A residência onde você mora é: ( ) própria （ ) alugada （ ) outra condição

Você tem religião? ( )Sim （ )Não Qual?

O que você deseja alcançar como trabalhador desta cooperativa?

Qual o $\quad$ seu $\quad$ grande $\quad$ desejo $\quad$ na

vida?

\section{Informações sobre a escolaridade}

Qual o seu nível escolar?

( ) Alfabetizado

( ) Ensino fundamental completo

( ) Ensino médio completo

( ) Ensino superior completo
( ) Não alfabetizado

( ) Ensino fundamental incompleto

( ) Ensino médio incompleto

( ) Ensino superior incompleto

Em qual série você está atualmente?

Você já estudou em alguma escola?

$\mathrm{O}$

que

você

) Sim

( ) Não

mais

gostava

na

escola?

$\mathrm{O}$

que

você

menos

gostava

na

escola?

Como era o tratamento dado a você?

Pelos professores:

Pelos funcionários:

Pelos colegas: 
Você gostava dos conteúdos / assuntos estudados? Eram úteis para a sua vida? Que assunto / conteúdo você gostaria de estudar hoje?

Que tipo de aula você prefere? (pode marcar mais de uma opção)

( ) Aula em que só o professor fala

( ) Aula em que professores e alunos falam

( ) Aulas com oficinas de produção

( ) aulas que utilizam música, teatro, dinâmicas de grupo, filmes etc.

Em sua opinião, os estudos podem proporcionar: (pode marcar mais de uma opção)

( ) Novas oportunidades de trabalho

( ) Ampliação da compreensão da vida

( ) ampliação da compreensão do mundo

( ) possibilidade de mudança de vida

(

outros

Pra você, como deve ser uma escola boa?

O que deve ter nessa escola?

O que ela precisa ensinar?

Como ela deve ensinar?

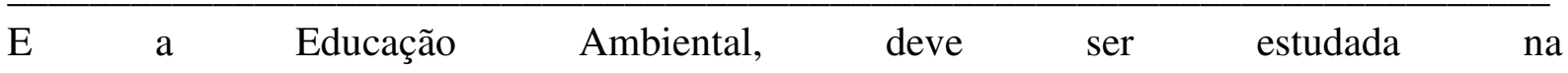
escola?

Para você, o que é Educação Ambiental?

Como você acha que se pode fazer Educação Ambiental?

Para você, seria bom ter uma sala de aula só para pessoas das cooperativas? Por quê?

Você estudaria nessa sala? 


\section{APÊNDICE B - ROTEIRO PARA ENTREVISTA COM SR. FERNANDO}

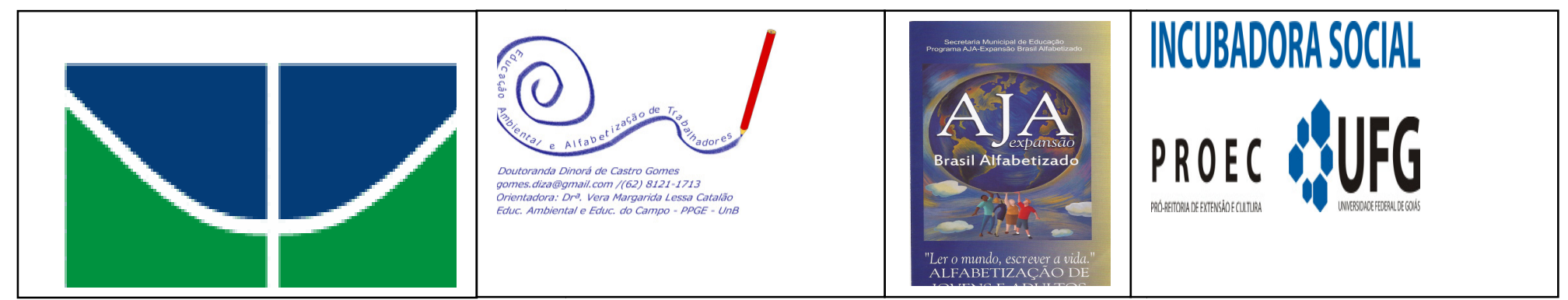

ROTEIRO PARA ENTREVISTA COM Sr. FERNANDO

Local de realização da entrevista:

Data:

Hora:

Entrevista $\mathrm{n}^{\mathrm{o}}$

1. Apresentação do entrevistador

Professora Dinorá.

Traz como tema "Educação Ambiental na Alfabetização de Trabalhadores de Cooperativa de Resíduos Sólidos: por um resgate de elos submersos”.

2. Identificação do entrevistado

Nome completo:

Idade:

Contatos:

Profissão/ocupação: 


\section{Roteiro para a entrevista:}

\section{Educação Ambiental, Alfabetização de Trabalhadores, Cooperativa de Resíduos Sólidos}

1- O que você considera mais significativo em relação a essa temática?

2- Você já vivenciou alguma experiência envolvendo esse campo temático? Qual e de que forma ela ocorreu?

3- Como tem se dado a relação entre a incubadora, as cooperativas de resíduos sólidos e a formação humana?

4- Qual a relação entre a Incubadora e a Educação Ambiental?

5- Alfabetização + Educação Ambiental junto a trabalhadores de cooperativas

6- Crise ambiental e cooperativas de resíduos sólidos

7- Cooperativas $\longrightarrow$ Cooperar $\longrightarrow$ Cooperação

8- Que pensadores inspiram suas reflexões em seu trabalho junto à incubadora?

9- A incubadora e a escolarização dos trabalhadores das cooperativas

10- A incubadora e o movimento em defesa dos trabalhadores das cooperativas 


\section{APÊNDICE C - ROTEIRO PARA ENTREVISTA COM NANÁ}

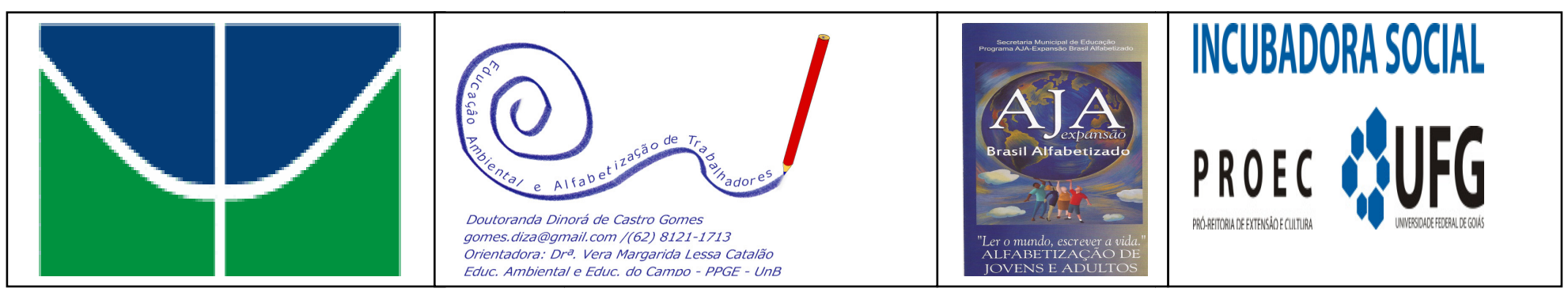

ROTEIRO PARA ENTREVISTA COM NANÁ

Local de realização da entrevista:.

Data:

Hora:

Entrevista $\mathrm{n}^{\mathrm{o}}$

1. Apresentação do entrevistador

Tema da pesquisa:

"Educação Ambiental na Alfabetização de Trabalhadores de Cooperativa de Resíduos Sólidos: por um resgate de elos submersos".

2. Identificação do entrevistado

Nome completo:

Idade:

Contatos:

Profissão/ocupação: 
3. Roteiro para a entrevista:

\section{Educação Ambiental, Alfabetização de Trabalhadores, Cooperativa de Resíduos Sólidos}

1- Esse é o tema da minha pesquisa. O que lhe chama a atenção em relação a esse tema?

2- Você já vivenciou alguma experiência envolvendo esse tema? Qual e de que forma ela ocorreu?

3- A turma de alfabetização de 2014. Comente.

4- Como foi pra você a experiência junto à turma que formamos?

5- Qual a relação entre a cooperativa ACOP e a Educação Ambiental?

6- Alfabetização, escolarização dos trabalhadores. O que você acha disso?

7- A formação humana no trabalho em cooperativas de resíduos sólidos. Como isso acontece?

8- Catador

9- Crise ambiental e cooperativas de resíduos sólidos

10. Cooperativas $\longrightarrow$ Cooperar $\longrightarrow$ Cooperação

11. Lutas $\longrightarrow$ Sonhos $\longrightarrow$ ACOP $\longrightarrow$ Movimentos

12. A vida 


\section{APÊNDICE D - ROTEIRO PARA ENTREVISTA COM SEU IRAMAR}

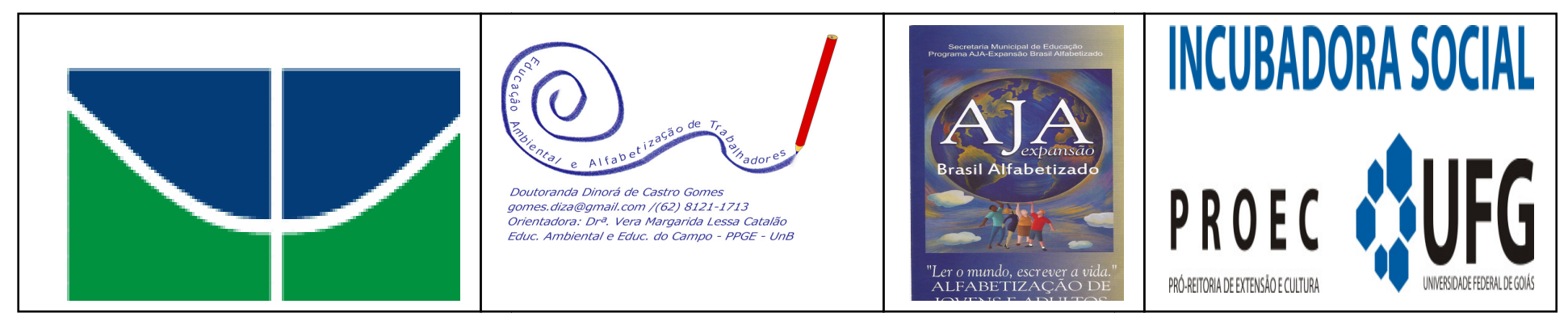

\section{ROTEIRO PARA ENTREVISTA COM SEU IRAMAR}

Local de realização da entrevista:

Data:

Hora:

Entrevista $\mathrm{n}^{\mathrm{o}}$

1. Apresentação do entrevistador

Tema da pesquisa:

"Educação Ambiental na Alfabetização de Trabalhadores de Cooperativa de Resíduos Sólidos: por um resgate de elos submersos".

2. Identificação do entrevistado

Nome completo:

Idade:

Contatos:

Profissão/ocupação:

3. Roteiro para a entrevista:

Educação Ambiental, Alfabetização de Trabalhadores, 


\section{Cooperativa de Resíduos Sólidos}

1- Esse é o tema da minha pesquisa. O que lhe chama a atenção em relação a esse tema?

2- Você já vivenciou alguma experiência envolvendo esse tema? Qual e de que forma ela ocorreu?

3- Relação entre a cooperativa ACOP e a Educação Ambiental

4- Alfabetização, escolarização dos trabalhadores

5- Contribuição socioambiental do trabalho dos Catadores de materiais recicláveis

6- Crise ambiental e cooperativas de resíduos sólidos

7- Cooperativas $\longrightarrow$ Cooperar $\longrightarrow$ Cooperação

8- Lutas $\longrightarrow$ Sonhos $\longrightarrow$ ACOP $\longrightarrow$ Movimentos

9- Condições de trabalho e reivindicações 


\section{APÊNDICE E - PLANEJAMENTO DE AULA}

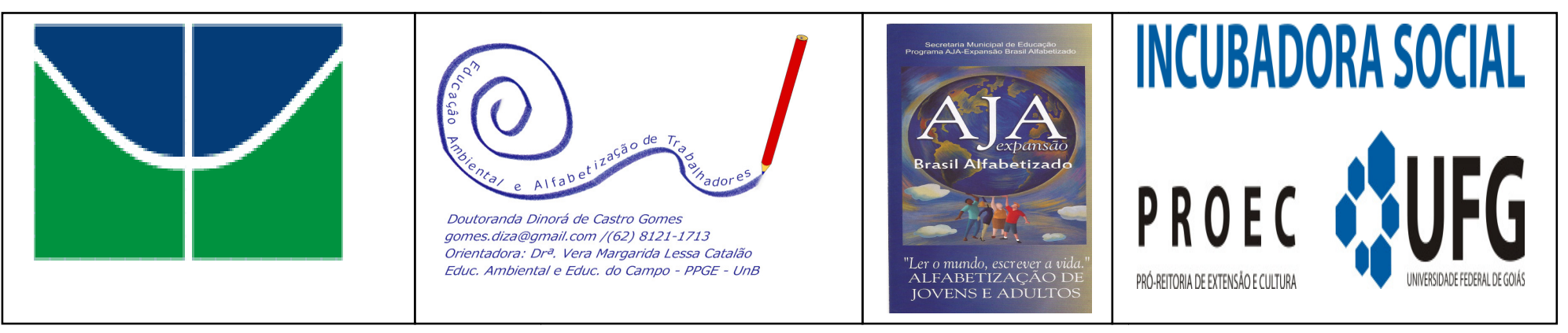

PLANEJAMENTO DE AULA

Data: 04 de junho de 2014

Tema: Lendo e escrevendo com os nomes das coisas, de cada um e da natureza.

Objetivo: Desenvolver leitura e escrita a partir do próprio nome, do nome dos colegas, das coisas e da natureza, sensibilização.

\section{Momento inicial:}

$>$ Em pé: trabalho de corpo

○ Em círculo: respiração, sensibilização e gratidão

- O ar que respiramos e o reino vegetal

Sentados: resgatar a aula passada

○ Palavra solta: recados, informações, combinados

- O nome de cada um

- Revisar o alfabeto: vogais e consoantes

- Encontros de vogais: AI, UI, OI, EU, UAI, EIA

\section{Momento Central:}

$>$ Leitura coletiva do texto "Nome das Coisas"

$>$ Enfatizar a poesia do texto

$>$ Cantar o texto: inventar a melodia

$>$ Contar a história do seu nome

$>$ Copiar no caderno as palavras que estão repetidas

$>$ Contar quantas vezes cada palavra está repetida

$>$ Escrever o numeral na frente da palavra

$>$ Vamos formar outras palavras a partir dessas palavras

$>$ Reescrevendo no caderno o nome das figuras que estão ilustrando a canção

\section{Momento Final:}

$>$ Avaliação da atividade desenvolvida: pode ser por uma palavra

$>$ Escrever essas palavras com canetão: letra de forma, em uma folha de chamex

$>$ Atividade para casa:

- respirar profundo;

- olhar devagar em volta: para o chão, para os lados, para o céu;

- escreva no caderno o nome das coisas da natureza que foram percebidas: terra, vento, redemoinho, céu, sol, estrela, flor, borboleta, formiga, abelha, córrego

- escreva uma poesia usando essas palavras 


\section{APÊNDICE F - ROTEIRO PARA RODA DE CONVERSA}

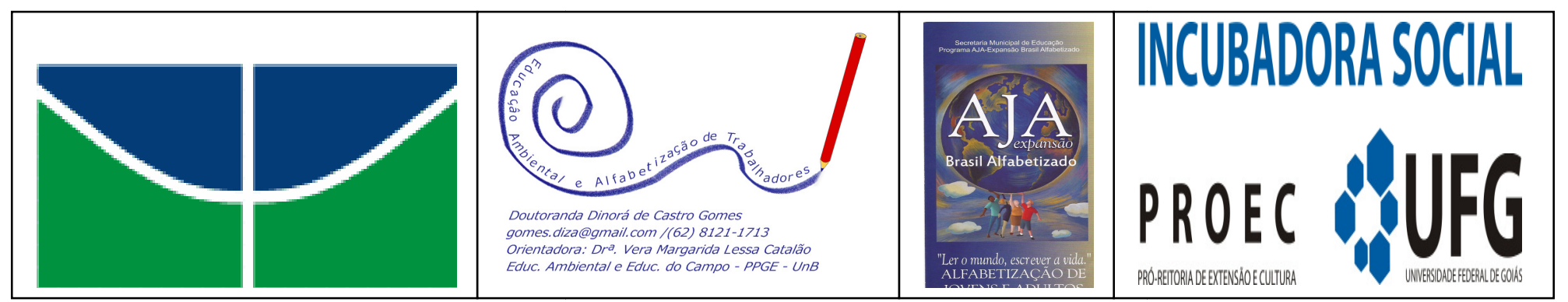

\section{RODA DE CONVERSA AVALIATIVA DAS ATIVIDADES COM A TURMA}

\section{Roteiro semiestruturado: outubro de 2014}

1. O que você sentiu quando foi convidado para aprender a ler e escrever em uma turma instalada aqui, nesta comunidade?

2. Você criou alguma expectativa em relação à turma? Qual? Comente.

3. Agora, depois de 5 meses de atividade, qual a sua opinião sobre a turma?

4. Você já desenvolveu alguma habilidade de leitura e escrita?

5. O que você tem aprendido nessas aulas?

6. Você gosta das atividades de desenhar e pintar? Por quê?

7. O que você acha da produção de artesanato com material da cooperativa?

8. Você está gostando dos conteúdos que estão sendo trazidos para as aulas?

9. Tem alguma atividade que você gostaria que fosse desenvolvida na turma?

10. Essas aulas estão ajudando você a conhecer melhor o mundo?

11. Elas fazem você pensar sobre o mundo?

12. O que você reflete a partir das aulas?

13. Sobre a natureza, as aulas têm ensinado alguma coisa? O que?

14. Mudou a sua forma de se relacionar com a natureza? Exemplo.

15. Sobre as águas, é importante estudar e conhecer? Por quê?

16. A sua relação com a água está diferente? Exemplo.

17. E a sua relação com você mesmo, mudou alguma coisa? Em que?

18. A sua maneira de se relacionar com as outras pessoas, com a comunidade e com a cidade, mudou alguma coisa? Exemplo.

19. O que você aprende nas aulas, tem servido pra sua vida?

20. O que você tem aprendido nas aulas tem ajudado você a viver melhor? Dê um exemplo. 


\section{ANEXO A - SOLICITAÇÃO PARA REALIZAÇÃO DA PESQUISA, JUNTO À SME DE GOIÂNIA.}

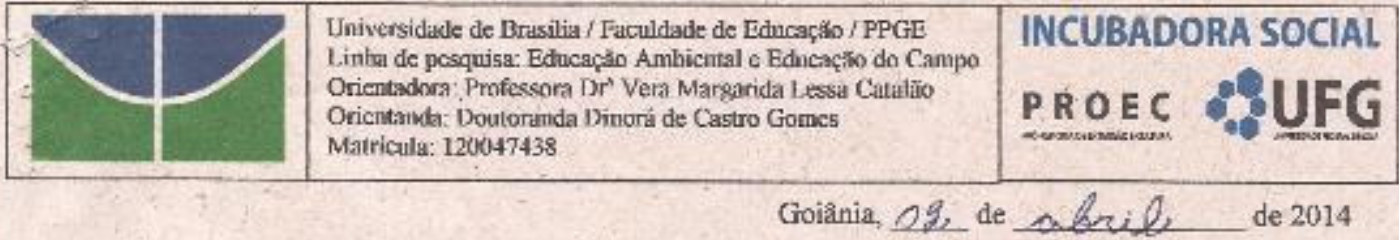

A DD. Secretéria de Educação Professora Neide Aparecida da Silva

Assunto: Autorização para realizaçăo de pesquisa acadêmica junto ao AJA-Expansão

Ilma Sta Secretária

Em nome do compromisso com a efetivaçắ da educaçấo como um direito e de qualidade para todos, busca-se, por meio de uma pesquisa acadêmica, caminhos que possam se aproximar das exigências de uma demanda especifica de escolarizaçāo de nossas comunidades e da suciedade. E uma parte da ciencia se ocupando com a construçâo de uma sociedade mais justa e mais humana. E com satisfaçāo e grande expectativa, portanto que solicitamos a sua autorizaçăo para a realização de uma pesquisa acadêmica junto a o Programa AJ A-Expansắo dessa Secrctaria.

Trata-se da realizaçāo de um projeto de pesquisa proveniente da linha de "Educaçăo Ambiental e Fducaçāo do Campo", da Pós-Graduaçāo em Educação da Universidade de Brasília, para se desenvolver junto ao grupo de adultos analfabetos trabalhadores de cooperativas de catadores de residuos sólidos, vinculadas à incubadora social da UFG. Traz como tema "Educaçāo Ambiental na Alfabetização de Trabalhadores de Cooperativas de Resíduos Sólidos: por um resgate de elos submersos" e sua pergunta principal é saber qual o potencial de transformaçāo suscitados pela inserçāo da EA no processo de alfahetizaçăo de adultos $\mathrm{em}$ cooperativas de residuos sólidos. Essa pesquisa insere-ge no âmbito da pesquisa qualitativa com op̣çào pela pesquisa-açāo e será desenvolvida por meio de cstratégias metodológicas diversificadas e oficinas pedagrógicas que possibilitem o aprendizado da leitura, da escrita e das operaçōes matemáticas a partir dos saberes trazidos pelos educandos - trabalhadores de cooperativas de catadores de residuos sólidos.

O percurso dessa pesquisa envolverá, por conseguinte! realizaçâo de entrevistas; produçōes de imagens e videos; acomp̨anhamento da formaçăo dos odrucadores populares; intervençăo ecopedagógica no processo de formaçāo junto à turma de cooperados participante. Esclarecernos que os résultados obtidos serâo utilizados e divulgados posteriormente, obedecendo aos critérios da ética de pesquisa, para os seguintes fins:

a. Na tese, para obtençāo do título de doutorado;

b. Como palestra, em comunidades cientílicas, culturais e educativas:

c. Para publicações acadèmicas em livros e periódicos. 
Pagina 2 de 3

Ressaltamos a importância dessa pesquisa considerando os avanços conquistados o os desafios ainda presentes no atendimento às especificidades e no cumprimento às Políticas Públicas de Alfabetizaçằo e Educaçāo de Jovens c Adultos em Goiânia, no Estado de Goiás e no Brasil. Tendo cm vista o compromisso dessa Secretaria, manifestado por seu empenho em fuzer uma educaçå de qualidade, agradecemos antecipadamente pela autorizaç̄ōo ao nosso trabalho de pesquisa.

Cordialmente,

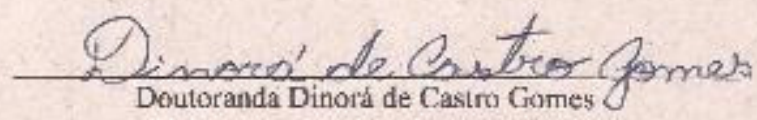

Uwa fuss Catalas Prof Dr $r^{5}$ Vera Margarida Lessa Catalăo 


\section{ANEXO B - TERMO DE ANUÊNCIA DA SME DE GOIÂNIA}

\section{Secretaria Municipal de Educaçäo Departamento Pedagógico}

\section{TERMO DE ANUENCIA}

Eu, Neyde Aparccida da Silva, Secretária Municipal de Fducação de Goiânia, autorizo a doutoranda Dinorá de Casiro Gomes, do Programa de PósGraduação em Educaçāo da Universidade de Brasília, autora do projeto de pesquisa denominado Educação Ambiental na Alfahetização de Trabalhadores de Cooperativas de Resíduos Sólidos: por um resgate de elos submersos, sob a orientação da Prota $\mathrm{Dr}^{\star}$. Vera Margarida Lessa Catalão, a realizar a pesquisa acadêmica mencionada, junto ao Programa AJA-Expansão, desta Secretaria, e a utilizar as informaçōes e imagens obtidas, obedecendo aos critériors da ética de pesquisa, para fins de obtençăo do título de doutorado, como palestra em comunidades científicas, culturais e educativas e para publicaçōes acadêmicas em livros e periódicos.

Goiânia, 8 de maio de 2014 .
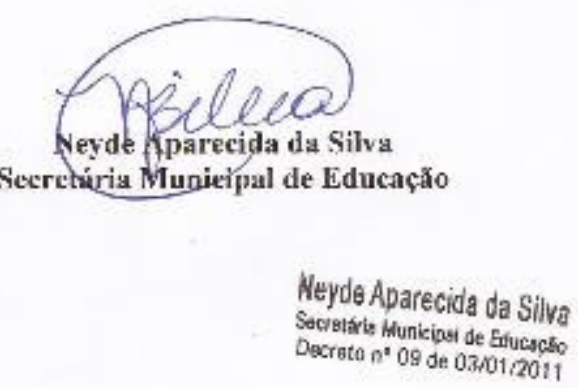


\section{ANEXO C - PARECER DE AUTORIZAÇÃO DA DEF-AJA}

\section{PREFEITURA}

Oticio $\mathrm{N}^{\circ}$. 062/2014-DEPE

Goînia, 11 de abril de 2014 . $\frac{\text { Secretaria Municipal de Educaçâo }}{\text { Departamento P’edagogico }}$

Prezado Senhora,

Em resposta à solicitaçẫo de Vossa Senhoria informamos que esta Secretaria autoriza a realização de pesquisa sobre o Programa AJA-Expansão, oferecido na modalidade de Educação de Adolescentes, Jovens e Adulıos na Rede Municipal de Educaçäo de Goiània. como parte das atividades do Curso de Pós-Graduação em Educaçāo, da Iniversidade de Brasilia, nivel doutorıdo, sob orientaçāo da Prof ${ }^{n}$. Dr². Vera Margarida Lessa Catalão.

O Programa AIA-Expansäo faz parte da estrutura organizacional da Proposta Político-Pedagógica da Lducaçăo de Adolescentes, Jovens e Adultos da SME. O foco í o atendimento às necessidades, anseios e especificidades dos educandos, visando garanlir sua formaçăo integral e seu pleno dircito de exercicio da cidadania. O Proj̣eto AJA-Expansāo, criado em 2001 e desenvolvido em parceria com a sociedade civil, universidades c outras instituiçôes, constitui-se em uma oportunidade de iniciar o processo de alfahetização de adolescentes, jovens c adultos, com vistas a garantir-lhes o acesso ao ensino fundamental. Tratı-se da concretizaçâo de uma bandeira de luta na defesa da educação como direito de todos, a iniciar-se pelo processo de alfabetização em Goiânia, fazendo parte de uma política pública municipal integrada de combate emergencial e estrutural às situaçốes de cxclusâo 5ocial. Fsse Projeto se configura em un movinemlo popular de alfahetizaça constituido a partir de uma resposta da sociedade civil, ONGs, universidades e instimiçôes - sensibilizadas com o indice de analfahetismo apontado pelo Censo de 2000 do IBCil, em Goviânia.

As (os) professoras (es) que atuam como allabetizadoras (es) no Projeto AJAtixpansâo são denominados de educadoras (es) populares. Pessoas com experiência em alfabetização ( $\mathrm{U}$ IA) eiou de participaçầo em movimentos populares.

Esta Secretaria compreende que pesquisas cducacionais realicadas na Rude pula academia, oportuniza a interlocução e a (re)aproximaçăo contínua da Universidade com a realidade social, oportunizando intervençčes que possam heneficiar o processo educacional. 


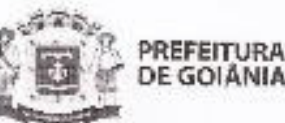

Secretaria Municipal de Educasåo Departamento Pedagógico

Para isso, considera a pesquisa um importante instrumento que conduz à açâo-reflexāo-açāo.

Dadas as consideraçōes acima, somos favoráveis à realização do trabalho. l'ara tanto, solicitamos que entre em contatı $\mathrm{com}$ a Divisão de Educação Fundamental de adolescentes, Jovens e Adultos, desta Secretaria (fone 3524-8956:8923), para agendamento de horário para obtençăo dos dados.

Atenciosamente,

Prot" Márcia Percira Mclo

Chefe da Divisāo de Educaçđ̃o Fundamental de Adolescentes, Jovens \& Adultos
Prof. Marcostodiro da Silva Diretor do Departamento Pedasosico

Ilma. Sr

Dinorá de Castro Gomes

Doutoranda do Curso de Pós-Ciraduação cm Educação

Faculdade de Educação/PP'GE

Universidade de Brasilia

Brasilia/DF 


\section{ANEXO D - TERMO DE CONSENTIMENTO LIVRE E ESCLARECIDO EDUCANDOS}
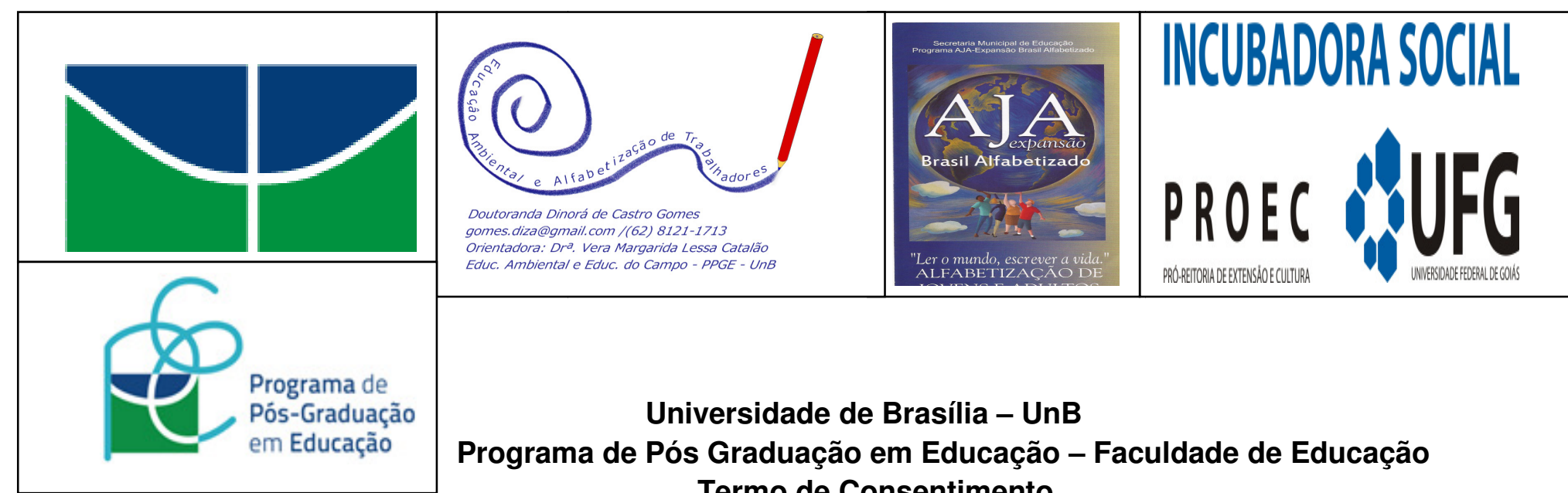

Esse termo de consentimento tem por objetivo convidá-lo a participar de uma pesquisa acadêmica intitulada: "Educação Ambiental na alfabetização de trabalhadores de cooperativa de resíduos sólidos: por um resgate de elos submersos". Sua participação se efetivará como aluno (a) do Programa AJA-Expansão de alfabetização de adultos, da Secretaria Municipal de Educação de Goiânia, com entrevistas e rodas de conversa e também em produção de imagem e áudio, que fazem parte dos procedimentos da pesquisa. Esclarecemos que será mantido o anonimato de todas as contribuições, e os resultados da pesquisa serão divulgados posteriormente da seguinte forma:

a. Na tese, para obtenção do título de doutora;

b. Em palestra, em comunidades científicas, culturais e educativas;

c. Em publicações acadêmicas em livros e periódicos.

Agradecemos sua colaboração e solicitamos sua assinatura no formulário abaixo.

Atenciosamente,

\section{Dinorá de Castro Gomes Doutoranda}

Profa. Dra. Vera M. L. Catalão Orientadora

\section{Consentimento do(a) Participante}

Eu,

DECLARO que fui esclarecido quanto aos objetivos e procedimentos da pesquisa de doutorado de Dinorá de Castro Gomes e participo voluntariamente desta pesquisa. Autorizo o uso da minha participação, assim como a utilização de imagens e áudios para os fins acima citados.

Goiânia, de de 
ANEXO E - TERMO DE CONSENTIMENTO LIVRE ESCLARECIDO SR. FERNANDO

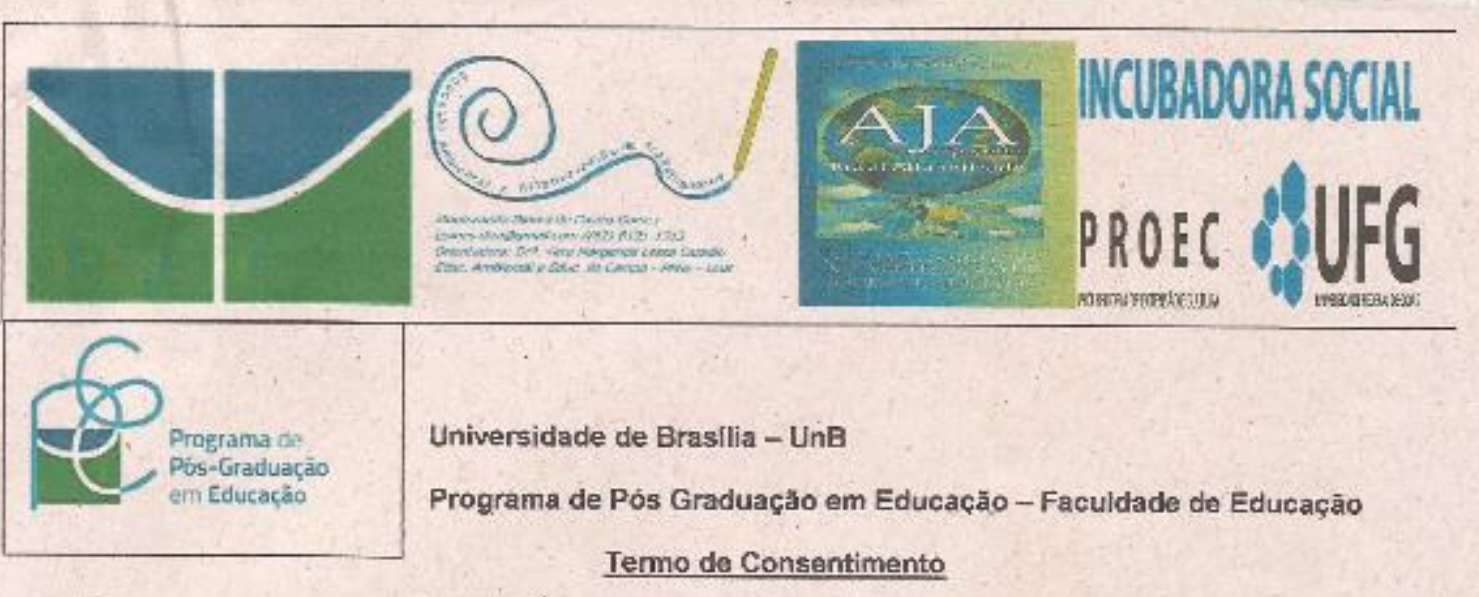

Esse termo de consentimento tem por objetivo convidá-lo a contribuir com uma pesquisa acadêmica intitulada: "Educaçăo Ambiental na alfabetizaçăo de trabaihadores de cooperativa de resíduos sólidos: por um resgate de elos submerso $5^{\circ}$. Sua participaçăo se efetivará como Coordenador da Incubadora Social da UFG, com entrevista e em produçăo de imagem e áudio, que fazem parte dos procedimentos da pesquisa. Esclarecemos sobre a utilizaçăo dos resultados bem como quanto do nome pessoal a ao uso das imagens feitas na ocasiăo e que os resultados da pesquisa serăo divulgados posteriormente da seguinte forma:

a. Na tese, para obtençăo do titulo de doutora;

b. Em palestra, em comunidades cientificas, culturais e educativas;

c. Em publicaçōes acadêmicas em livros a periódicos.

Agradecemos sua colaboraçāo e solicitamos sua assinatura no formulário abaixo

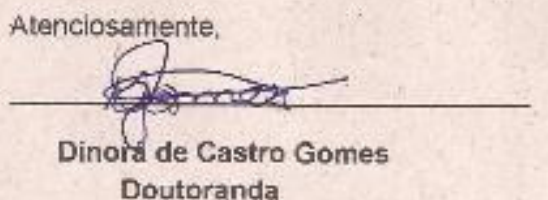

Doutoranda
Profa. Dra. Vera M. L Catalảo Orientadora

\section{Consentimento do(a) Participante}

EU, FERNANDO ANTONIO FERREIRA BARTHOLO, declaro que fui esclarecido quanto aos objetivos e procedimentos da pesquisa de doutorado de Dinora de Castro Gomes e participo voluntariamente desta pesquisa. Autorizo o uso da minha participaçåo, assim como a fazer a revelaçăo do meu nome pessoal a a utilizaçăo de imagens e áudios para os fins acima citados, obedecendo aos critérios da etica de pesquisa.

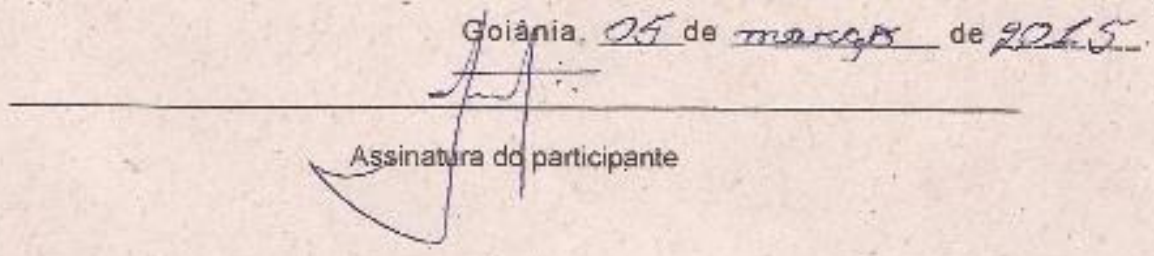




\section{ANEXO F - TERMO DE CONSENTIMENTO LIVRE ESCLARECIDO ELIZÂNGELA}

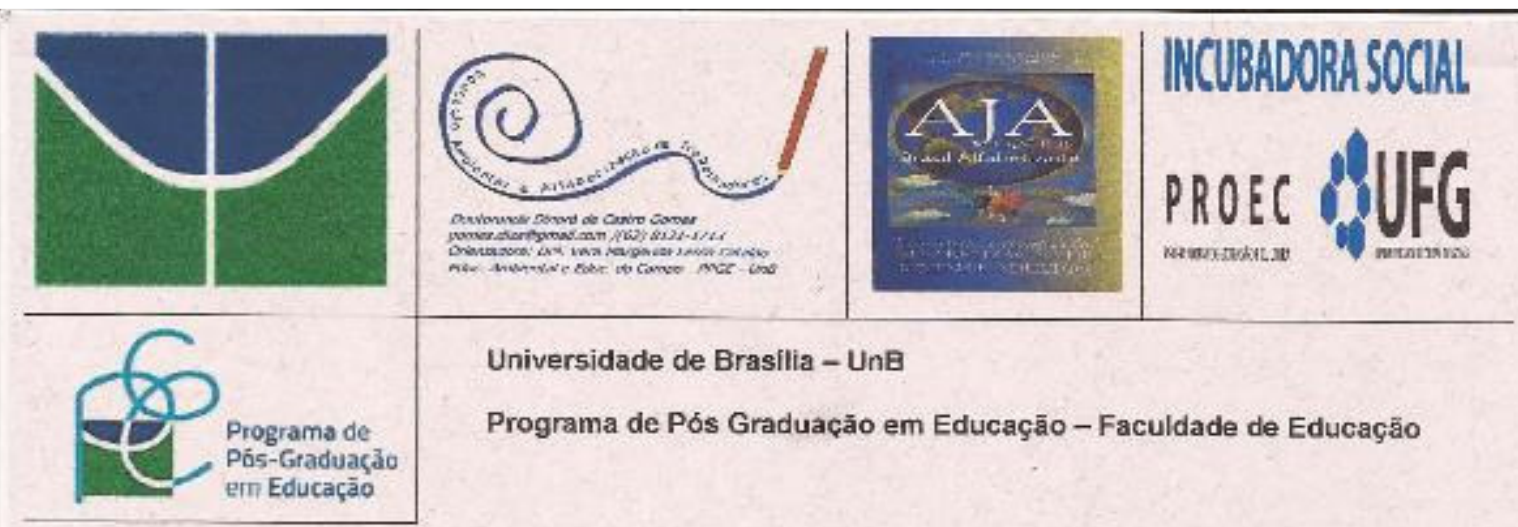

\section{Termo de Consentimente}

Esse termo de consentimento tem por objetivo convidà-la a participar de uma pesquisa académica urituluada- "Educaçāo Ambiental na alfabetizaçāo de trabalhadores de cooperativa de residuos sólidos: por um resgate de elos submersos". Sua participaçăa se efetivara como Educadora Popular vinculada ao Projeto Cata Sol da Incubadora Social da UFG, com entrevistas e rodas de conversa e também em produçāo de imagem e áudio, que fazem parte dos procedimentos da pesquisa. Esclarecemos sobre a utilização dos resultados bem como quarito do nome pessoal e ao uso das imagens feitas na ocasiâo e que os rosultados da pesquisa serão divulgados posteriomente da seguinte forma:

a. Na tese, para obtençäo do titulo de doutora,

b. Em palestra, em comunidades científicas, culturais e educativas,

c. Em publicacóos académicas em livros e periódicos.

Agradecemos sua colaboraçăo e solicitamos sua assinatura no formulário abaixo.

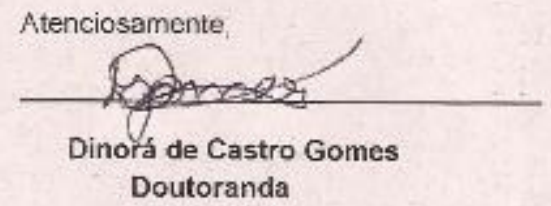

Profa. Dra. Vera M. L. Catalåo Orientadora

\section{Consentimento do(a) Participante}

Eu, MARIA ELIZÁngeLA DA SILVA, declaro que fui esclarecida quanto aos abjetivos e procedimentos da pesquisa de doutorado de Dinorá de Castro Gomes e participo voluntariamente desta pesquisa. Autorizo o uso da minha participação, assim como a fazer a revelaçăo do meu nome pessoal e a utilizaçăo de imagons e áudios para os fins acima citados, obedecendo aos criterios da ética de pesquisa.

$$
\text { Golänia, } 09 \text { de marye de } 20,55 \text {. }
$$

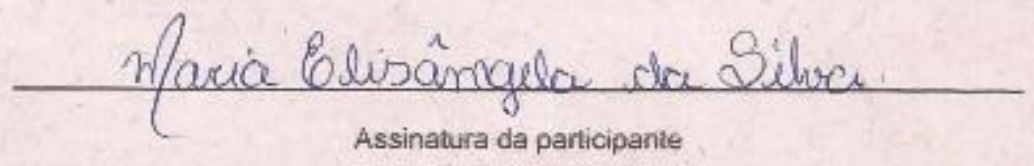




\section{ANEXO G - TERMO DE CONSENTIMENTO LIVRE ESCLARECIDO SEU IRAMAR}

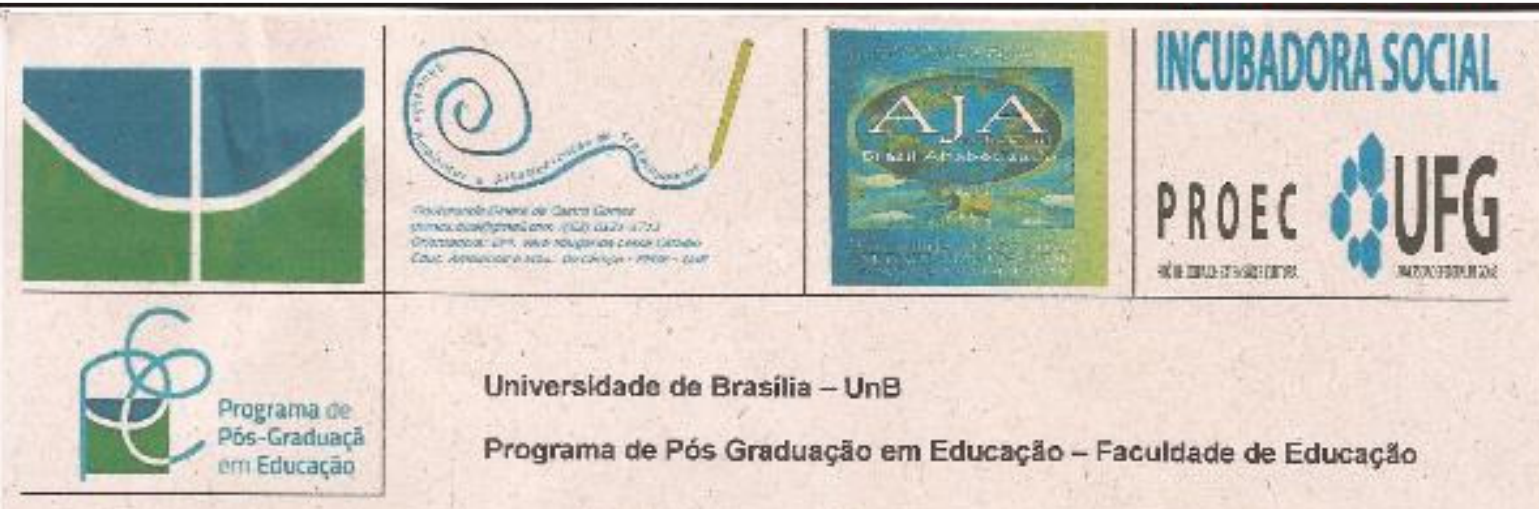

\section{Termo de Consentimento}

Esse termo de consentimento tem por objetivo convidá-lo a contribuir com uma pesquisa académica intitulada: "Educaçåo Ambiental na alfabetizaç̧ăo de trabalhadores de cooperativa de residuos sólidos: por um resgate de elos submersos". Sua participaçăo se efetivará como presidente da cocperativa ACOP e membro fundador da comunidade do Setor Albino Boaventura, com entrevista e também em produçăo de imagem e áudio, que fazem parte dos procedimentos da pesquisa. Esclarecemos sobre a utilizaçăo dos resultados bem como quanto do nome pessoal e ao uso das imagens feitas na ocasiåo e que os resultados da pesquisa serăo divulgados posteriormente da seguinte forma:
a. Na tese, para obtençåo do titulo de doutora:
b. Em palestra, em comunidades científicas, culturais e educativas:
c. Em publicaçoses açadèmicas em livros e periódicos.

Agradecemos sua colaboraçåo e solicitamos sua assinatura no formulário abaixo.

Atenciosamente,

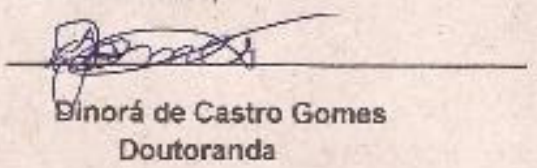

\section{Profa. Dra. Vera M. L. Catalăo Orientadora}

\section{Consentimento do(a) Participante}

Eu, JOSÉ IRAMAR ARAUJO SOUSA, declaro que fui esclarecido quanto aos objetivos e procedimentos da pesquisa de doutorado de Dinorá de Castro Gomes e participo voluntariamente desta pesquisa. Autorizo o uso da minha participaçåo, assim como a fazer a revelação do meu nome pessoal e a utilização de imagens e audios para os fins acima citados, obedecendo aos critèrios da ética de pesquisa.

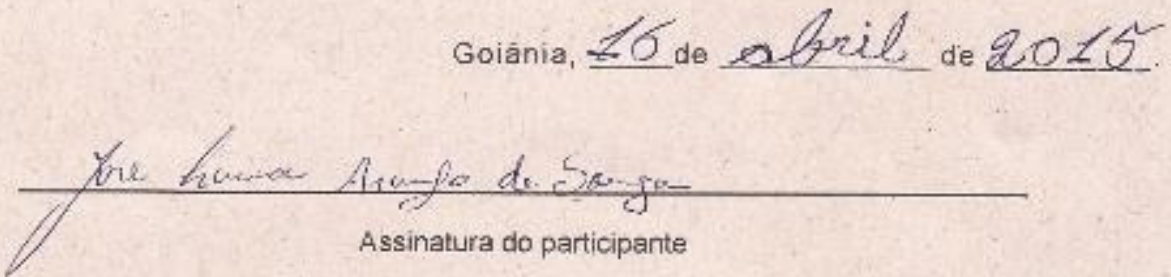




\section{ANEXO H - CADASTRO DO EDUCANDO JUNTO AO PROGRAMA AJA- EXPANSÃO}

Secreturia Municipaj de Educaçăo

Degariamento Pedagdgicon

Divisăo de Educaçōo Fundamentul de Adolescentes, Javens e Adultos

Programu AJA-Expansial' Brasil Alfabetizado

CADASTRO DO(A) FDUCANDO(A)

CÓDIGO DA TURMA: COOHGO DO ALFABETIZANDO:

NOME DO(A) EDUCANDO (A):

DATA DE NASC.:

NATURALIDADE: PROFISSAO SI:XO: NACIONAIIDADF: TRABALHA: ( ) SIM ( ) NÃO

RG(aluno): LOCAI DE TRABALHO: ÓRGĀO FXPFDIDOR:

DATA DA EXPEDIÇÃO; CPF:

NOME DO PAI:

NOME DA MÄE;

PREQUENTOUA ESCOLA: SIM( ) NÃO( ) QUANTOS ANOS

QUANTOS MISES

COR/RACA:( Mmarela ( ) Branca( ) Indigena( ) Parda( ) Prela

CTULIZA ÓCUIOS: ( )SIM ( JNÄO TFM DIFICULDADES DEENXERGAR: ( )SIM ( )NÃO NECESSIDADE ESPECIAL: ( )Deficiência Auditiva-Surder profunda

( ) Deficiência Mental

() Deficiéncia Múltipla

\section{ENDERECYO RESIDENCIAI.}

CEP: BAIRRO:

RIA:

$\mathrm{N}^{\mathrm{*}}$ ( Deficiência visual - cegacira

CIDADE: TELEFONE:

MATRICULA 2014

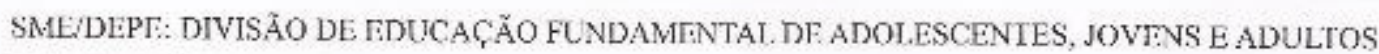
INSTTIUICৃĀO PARCEIRA:

RISPONSAVEL PELA PARCERIA:

LOCAJ. DE. FUNCIONAMINTO:

TELEFONE DE CONTATO; HORÁRIO DAS AULAS:

DATA DA MATRICULA: 1 EDUCADOR(A):

$\frac{\text { ASSINATURA DO(A) EDUCANDO(A) }}{\text { ASSINATURA DO(A) EDLCADOR(A) }}$




\section{ANEXO I - CADASTRO DO EDUCADOR POPULAR JUNTO AO AJA-EXPANSÃO}

Secretariu Municipal de Ruiucıçăo

Departamento Pealugangico

Divisao de Educaçio Fundamental de Adolescentes, Jovess c Adultos

Programa A.JA-Rxpass5o/ Brasil Allabetixado
Goiânia

ofuturo se faz agore

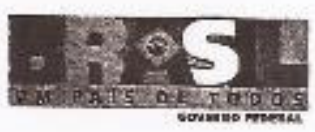

CADASTRO DO EDUCADOR

NOME DO(A) EDUCADOR (A):

DATA DE NASC.: SEXO: NATURALIDADE:

$\mathrm{RG}$ : ORGĀO EXPEDIDOR:

UF: DATA EMISS $\bar{O}$ :

CPF: PROFISSÃO

NOME DO PAI:

NOME DA MÃE:

ESCOLARIDADE: ESRADO CIVIL:

SITUACXAO OCUPACIONAL:

COR/RACA: ( )Amarela ( ) Branca ( ) Indigena ( )Parda ( ) Preta

ENDERECOO RESTDENCIAL

CEP: BAIRRO:

RUA:

$N^{5}:$ QDA: LT:

CIDADE: FONE FTXO;

FONE CELULAR: EMAIL:

PARCERIA

SME/DEPE: DIVISĀO DE EDUCAÇÃO FUNDAMENTAL DE ADOI.ESCENTES, JOVENS E ADULTOS INSTITUIÇÃO PARCEIRA:

RESPONSÁVEL PELA PARCERIA:

LOCAL DE FUNCIONAMENTO:

TELEFONE DE CONTATO: HORARIO DAS AULAS: 